allum aly

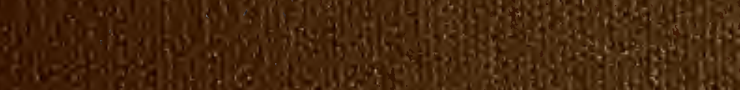
H. SI

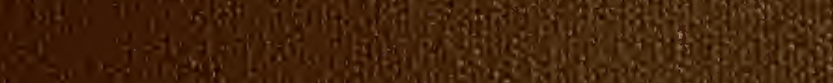

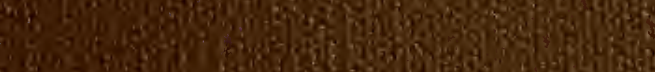
35. 2)

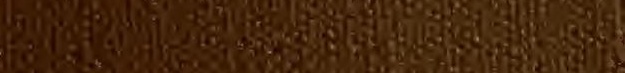
If 6 .

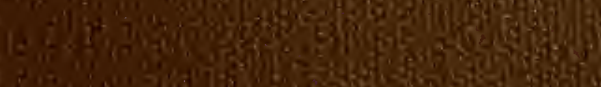

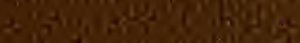

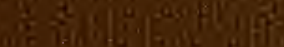

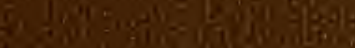

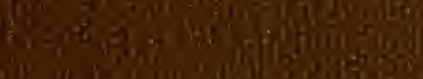

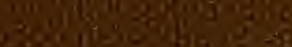

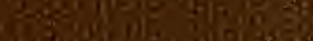

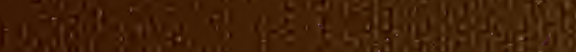
on:

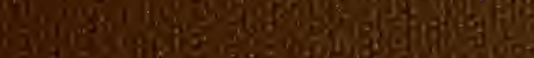
Q

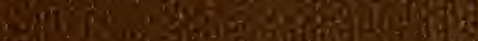

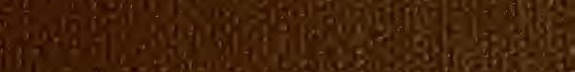

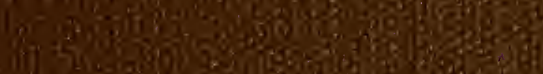

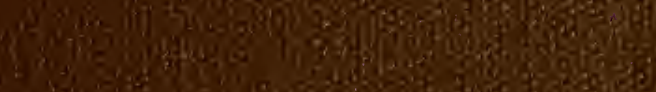
B.

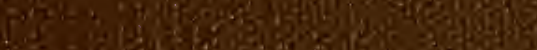

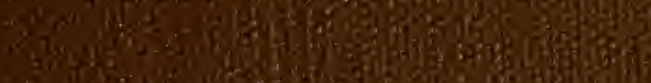

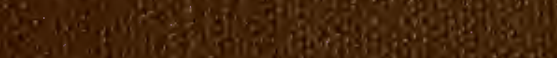
onte is * a 1.

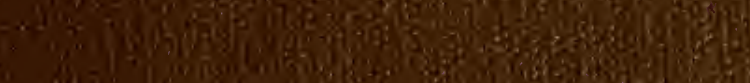




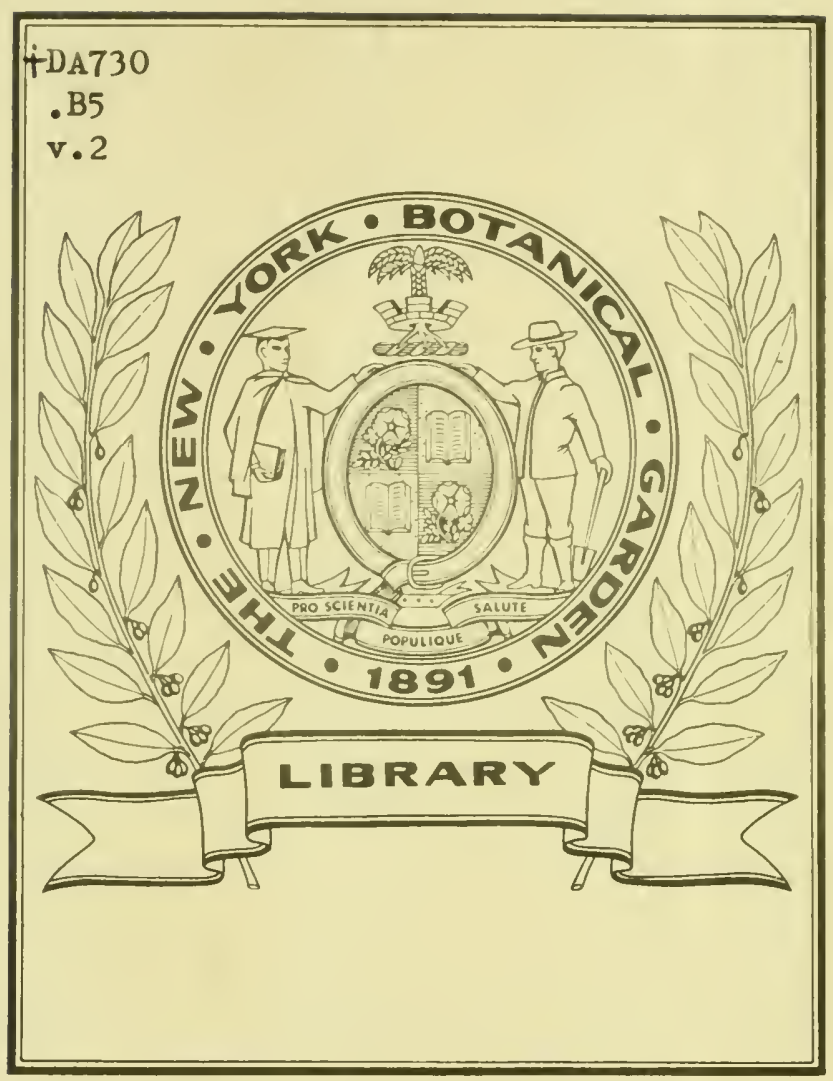






Mlyabeth Lempinie, torne

w. pe timate trind A. At. Ilem morn't itfucic 13 th 185.3 - 




$$
\text { 1) Jinlled/1ivin }
$$

Le Tive pase zurs

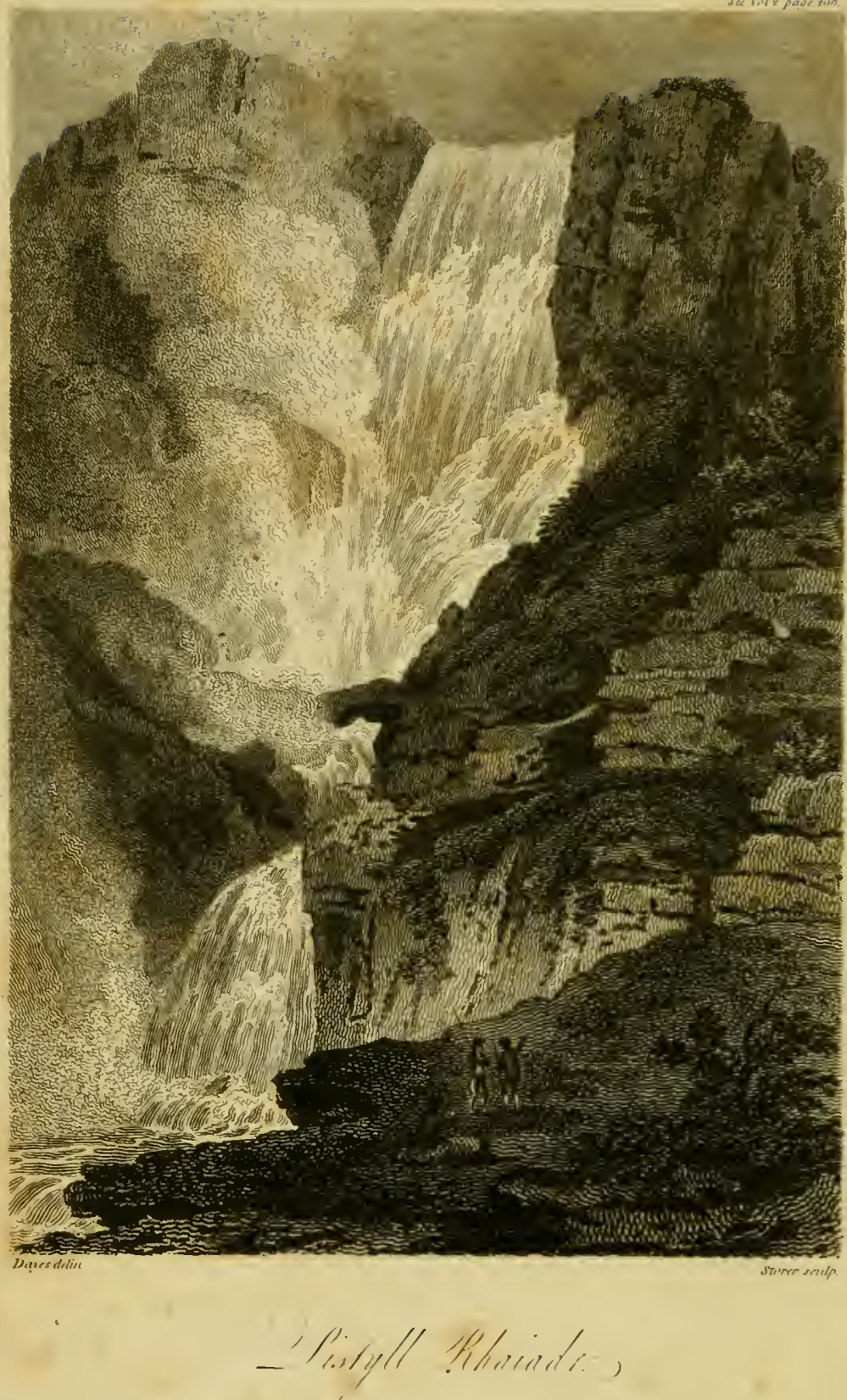




\section{NORTH WALES;}

INCLUDING ITS

SCENERY, ANTIQUITIES,

\section{CUSTOMIS,}

AND SOME \&KETCHES OF ITS

NVATURALA IHISTTORH;

DELINEATED TROM

TWO EXCURSIONS THROUGH ALL THE INTERESTINC

PARTS OF THAT COUNTRY,

During the Summers of 1798 and 1801 .

BY THE REV. W. BINGLEY, A.M.

FELLOW OF THE LINNEAN SOCIETY,

AMD LATE OF PETERHOUSE, CAMBRIDGE.

Illugirated with a Map, Frontippieces, and Mufic.

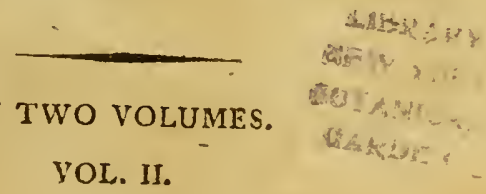

\section{Lonoan:}

PRINTED FOR T. N. IONGMAN AND O. REES,

PATERNOSTER-ROW.

1804 . 



\section{CONTENTS}

OF THE

\section{$S E C O N D \cdot V O L U M E$.}

\section{CHAP. I.}

\section{Caernarvon, through Beddgelert, to}

\section{HARLECH.}

Pont Aberglâfllyn.-Mountain Road, and new Road from Beddgea lert to Tanybwlch. - Tanybwlch. - Vale of Ffefinog. - Inn.SMaentzurog.-Tzurog.-Waterfall, called Rhaiadr Dú.-Impending Scenery. - Llyntecwyn Ucha.-Llantecwyn. - Beautiful Vale,-Harlech.-Harlech Cafle.-Extenfive View.-Hifrory of Harlech Cafle.-Bronzuen.-Valiant Defence in the Reign of Edrward IV.-Mephitic Vapour.-Inn and Guide, Page I

\section{CHAP. II.}

Excursion from Harlech to Cwm Bychan. Cylch Cyngrair, or Drwidical Circles.-Cwm Bychan.-Bwich Tyddiad. - Drws Ardudwy.-Cwm Nancoll.-Cataraa.-Sarn Badruyg. - Cantref Gwaelod, or overflowed Hundred-Cardi. gan Bay,

\section{CHAP. III.}

\section{HARLECH TO BARMOUTH.}

Upright Stones.-Cromlechs. - Ancient Barrows, the Mode of forming, and the Utility of them.-Bermouth. - Houfes fingularly

\section{A. 3}

fituated. 
fituated. - Inn. - Beach, and River. - Uncommcnly bcautiful Scenis -Trade of Barmouth, - _ _ _ Page 21 CHAY. IV.

Barmotthi to Dolgerle.

The River Mawddach.-Beaitiful Sicncry.-Dolgelle.-W"bimficat Defcription of Dolgelle. - Fuller's Enigmatical Defoription.Trade. - Inn.-Fortified in the Reign of Cliarles 1.-Account of Places zeorth vifiting in the Neigbbourtbood of Dolyelle,

\section{CHAP. V.}

Excursion from Dolgelle to KemMer ABbey AND THE WATEREALIS.

TV Vanner, or Kemmer Albcy.-Suffers from a Deception of one of the Monks,-T he Catarait at Dolmelynllyn. - Difant W aterfull.the Catarad of the IIIawiliach. - The Catarad of the Cain.Guide;

CHAP. VI.

Dolgelie to Machynlifth.

Viequ of the Country round Dolgelle.-The Pool of the Three Pebbles; and Tradition resperting the enormous Giant Idris.The Blue Iion, and Edward Gones. - Afcent to the Summit of Cader Idris:-Account of Ydris. - Cafcades.-Lly'n y Cas.-. Prosped from the Summit of Cader Idris.-Catarad near the Blue Lion. - Machynlleth. - Mr. Aikin's Defcription of the Devil's Bridge, near Harod, in CardiganßBire, 40

\section{CHAP. VII.}

Machynleth to Ilanydloes.

Account of the Mountain Plynlimmou. - The Sourre of the Sewcrn.

-Cataraa.-Lianyclloes,

$5 \cdot 4$

CHAP. 


\section{CHAP. VIII.}

\section{Llanydloes to Newtown.}

$V$ iene of the Country. - Anecilote of Edward Herbert, Efq. - Nezo. town.-Catarat.-Dolforwyn Cafle. - Hiflory of this Fortsefs. -The Story of Sabrina, and the Origin of the Severn, Page 59

\section{CHAP. IX.}

\section{Neivtown to Montgomers.}

Fiew near Abermule. - Montgomery. - Church.-Hiflory of the Town. - Montgomery Cafle. - Skctch of its Hijlory.-Rural Scene.-Leland's Defcription of the Town.-The Cucking Stool, formerly in Uje hers.-Memoranda of Lord Herbert of Chirbury,

CHAP. X.

\section{Montgomery to Welsh Pool.}

Welf Pool.-Church.-Parvis Cafte.-Hiffory of. Powis Caftle, and Account of Powifland.

\section{CHAP. XI.}

\section{Welsh Pool to OsWestrey.}

The Breiddin Hills. - Llanymynech - Llanymynech Hill, and Cavern called Ogo.-Lime 2uarrics.-Proppect from the Hill. - Account of Ofa's Dyke.-Ofweflry. - Houfe of Induftry.-Account of the Death of Of:uald-Monjfery. - Glburchyard's Encomium or Ofweflry and the Wells People.-Ofweflry Cafle.-Account of vurrious Difurbances in the Marches of IVales. - Sicge of Ofweftry Gajlle, and daring Attempt of a Kouth, who. fucceeded in forcing open thic Gates.-Charters and Trate.-Sketch of the Hi,pory of the W'elfo Marches, 
CHAP. XII.

OsWestry to RUabon.

Shirk.-Aquedua.-Church.-Memoranda of Dr. Sacheverel.Chirk Cafle, and extenjive Vicw.-Anecdote of a whimfical Painting of Piflyll Rhaiadr. - Hifory of Chirk Cafle.-Memo. randa of Sir Fokn Trevor, formerly Mafer of the Rolls.Beautiful Scene at Nero Bridge.-Ruabon.-Cburch and Monuments.-Dr. David Powel,

Page I 10

\section{CHAP. XIII.}

\section{Excursion from RuABon to BANGor Iscoed.}

Wynnfiay.-Beautiful Scene at Nant y Bele.-Overton-Conjecures on the original Planting of $Y_{e r w}$ Trees in Church-yards.-Bangor Ifcoell, the oldeft Monafiery in Britain.-Account of Gildas Nennius, and of $y_{y}$ flis, the Authors of two very ancient Hifories of Britain,

I 2 I

CHAP. XIV.

Ruabon to TVREXHAM.

Erddig.-Wrexbam.-Church and Monuments. - Anecdote of Elibu Yale.-Wrexham Fair. -Trade and Manufaciories,

134

CHAP. XV.

EXCURSION FROM WREXHAM TO HOLT. irillnge of tiolt.-Caple. - Hiflory of tire Cajle, 140 CHAP. XVI.

WREXAM TO MOLD.

Komuntic Gien.-Cuergaris.-Hi iory of Caergaurle Cafle.-Mold. - Churth.-Hitory of Mold Cafle. - Account of Maes Garmon, and the "Allesia" Iridory.

145

CHAP. 


\section{CHAP. XVII.}

\section{Mold to RuthiN.}

Vale of Clwayd.-Llairbaiadr.-Church.-Epicaph recording a Defcent from one of the Webh Princes. - The Well at Llanrbaiadr. Rutbin.-Churcb.-Cafle.-Hijtory of the Town and Cafile,

Page 154

\section{CHAP. XVIII.}

\section{Ruthin to Llangollen.}

The Vale of Crucis. - The Pillar of Elifeg. - Valle Crucis Abbey. Singular Explanation of an Infcription.-Llangollen.--Llangollen Bridge and Cburch - Plâs Newydd, the Seat of Lady Eleanor Butler, and Mifs Ponfonby.-Caftell Dinas Brân-Craig Eglwuyjeg. - Hijlory of Caftell Dinas Brân.-Mifanwy Vechan.Excurfion round the Vale of Llangollen.-Agueduat near Pont $y$ Cydyllite -Views. - The Inn at Llangollen, . - . 160

\section{CHAP. XIX.}

\section{Llangollen to CoRwen.}

The Vale of the Dee.-Llanyflio Hall. - Extenfive Propeci.-Me. moranda of Owen Glyndwr.-Corwen.-Church._- Piaurefque Seene.-Cefyn Creini.-Excurfion to Glymn Bridge, - 375

\section{CHAP. XX.}

\section{CoRweN TO BALA.}

The Vale of Edeirnion. - The Waterfall at Cynzudd.-Llanderfel. Account of the Image of Derfel Gadarn, and fome Superfitions of the Wellh People.-Execution of Friar Foreft, and the fingular Completion of a Prophecy. - Memoranda of the Wello Bard Llywarch Hên.-Bala.-Bala Lake.-Account of a Fijh called Gwyniadl, found here.-Dreadful Overflowings.-Exisurfion round the Lake. - The Phenomenon called by the Welfo Dear Dor. 
- An Adventure of two Gentlemen at Llanwuchllyn.-Cafell Corn: dochon._Caer Gai.-The River Die, _ Page 185

\section{CHAP. XXI.}

BALA TO SHREWSBURY.

Cafcade at Pont Cynouydd.-Rbiwedng.-Trûm y Sarn.-The Berquyn Mountains. - Illangynog.-Slate Quarries. - Hazardous Mode of conveying Slates from the Mountain into the Vale.-Lead Mines.-Llanrbaiadr. - The Catarait of Pifyll Rbaiadr. - The Vale of Llanged win. - Knockin.-Account of the fingular Difcovery of a Murderer.-Kynaflou's Cave in Neffcliff.-Montford Bridge. -Shrewpoury,

\section{CHAP. XXII.}

\section{SHREWSBURY.}

Shervfbury Cafle.-Walls.-County Gaol.-Bridges.-Sirrezufoury Abbey.-Ancient Oratory.-St. Giles's Church.—St. Alkmund's Churcl,.-Daring Feats on the Point of the Spire.-A fingular traditional Story. - St. Mary's Chur.h. - Account of a Man killed in fiding down a Rope, from the Spire, to a Field, acrofs the River. St. Fulian's church.-Old St. Clad's.-New St Chad's. - The 2uarry. - Account of the Houfe of Induftry. - The Ruins of the Three Friaries. - Public Buildings.-Hiflory of Sbrcwopury.Lift of remarkable Events,

$-\quad 213$

\section{CHAP. XXIII.}

\section{The Manners and Customs of the Welsh,}

Account of the Welns Manners in the Twelfth Century-Mode of figlting.-Domefic Cufloms and Drefs. - The Officers belonging to the Court in the Tenth Century. - The Officers of the Nobility.$V$ arious fingular Laws and Cufloms of this Period. - State of Socichy in the fubfequent Centuries. - The Laws of the Chace. - The Ancient Games. - Welfo and Englifs Contegs after the Infurrecion 
of Glyzdiar. -T THE MANATES OF THE MODERN WEISH.-Im. pofitions fometimes praflifed on Englifh Truvellers. - Irafailility. The We'b Coltages. - I'omen. - Luriofity. - Superfitions. - sleconni of a Suppoyed Kind of Aërial B.ings called Kuockers.Witches.-Coelcerlb. - ir Eryr, _Canswyll Corph. - Offering of Enemies. - Wells of Saints.-Plygain.-Leeks on St. David's Day.-Terning --Mrode of Courtbip called Bundling.-Cufloms at Weddings. - Funerals. - Offerings at Funerals. - Rsajon for not interring on the North sides of Churcbes.-Planting the Graves,

Page $24 \frac{9}{6}$

\section{CHAP. XXIV.}

\section{Essay on the Origin and Character of THE WELSH LANGUAGE.}

The Charaicer of the Language. - Of the Poetry. - Other Languages Dialeiss of the Welfb. - Analogy betwixt the Hobrew and Welfs. Betwixt the Greek and Welf..-The Welfs Letters, and tbeir Force.-Lif and Explanalion of feveral of the primitive Words. - Lif of Welfs Words in common Uje.-The Saxon Alpbabet moft probably belonging to the Welfs. - Prefent State of the Wells Language,

\section{CHAP. XXV.}

SKetch of the History of THe WeLsh Bards

\section{AND MUSIC.}

Account of the Druids, their Funclions, Manners, and Cuftoms.Their Extermination by the Romans. - The fubfequent State of Poetry and Mufic. - The Reformation effeqed by Griffith ap Cynan, in the Truelfib Century.-The Ctaffes of the Bards.The Eifeddfod, or Tricunial Afembly. - The Degrees in Poetry and Mufic. - T the Privileges and Revenues of the Bards. -Their fuppofed Maffacre by Order of Edaward I. - Their Hifory continued from thence to the prefent Time.-Account of the Well/s Mufical Infruments. - The Harp. - The Crath.-The Pibeorn. -Obforvations on the IVElf Mufic.-Oligetions to the Laws of 
Counterpoint being known among the aneient Bards; and to the generally fuppofed Antiquity of the prefent national Tunes.-Characier of the prefent $W$ eljb Mufie,

Page $31 \mathrm{I}$

A Guide throqgh North Wales, - 345

Frora Canbrica: A Syfenatical Catalogue of the more uncommon Welf Plants, with their Places of Growth, and Times of towering, 


\section{NORTH WALES:}

INCLUDING ITS

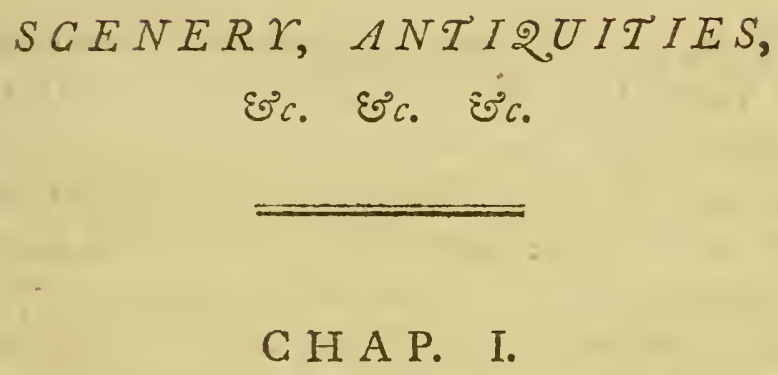

C.aernarvon, through Beddgelert, to HARLECH.

Pont Aberglâflyn.-Mountain Road, and new Road from Beddge. lert to Tanybwlch.-Tanybwlch.-Vale of Ffefiniog:-Ien.- 'Maentwrog. - Twrog. -Waterfall, called Rhaiadr Dû.-Impending Scenery. - Llyntecwyn Ucba.-Llantecwyn. - Beautiful Vale.-Harlech.-Harlech Cafle.-Extenfive View.-Hiflory of Harlech Cafie. - Bronzuen. - Valiant Defence in the Reign of Edward IV.-Mephitic Vapour.-Inn and Guide.

$\mathrm{H}_{\text {Aving }}$ remained at Caernarvon a length of time fully fufficient to enable me to vifit and examine all the places worth notice within a circle of about thirty miles on every fide of it, I now proceeded towards Beddgelert and Harlech, in my journey to the other parts of North Wales. - The road to VOL. II. Beddge- 
Beddgelert, toggether with tilc fcenery around that place, have already been defcribed. I fhall therefore, in this chaptcr, fuppofe inyfelf proceeding fouthwards, immediately from

\section{Pont Aeerglasliyn.}

From this celebrated bridge there are two roads to Tanybwlch, the low or new road, and the mountain road, the former of which occupies about ten, and the latter eight miles. Till within the laft two years, carriages were ufually taken along the mountain-road, a feries of rocky fteeps, which were confidered fo dangerous, that mort perfons preferred walking for at leaft five of the eight miles: and feveral people, to avoid it, have even gone more than forty miles round. For about two miles, this romantic, though rude way, commands feveral beauriful and extended proipects. From one very elevated fituation, I had in my former journey a moft delightful view of all the fine and mountainous country around me: Harlech and Criccieth caftles were both in fight, and the long extent of ground forming the promontory of Llỳn, was vifible even to its extremity.

Beyond the bridge, on the new road, which is formed through the more flat and level country towards the fands, the varied fcene of wood, rock, and mountain, is uncommonly fine. In fome fituations the view is confined to the immediately fur. rounding 
rounding rocks, whilft in others the eye wanders over a vaft expanfe of mountains. On one elevation I obferved no fewer than fix ranges of mountain, one above another, the uppermoft at a great diftance. I paffed on the left two confpicuous and conical fummits called Moelwyn. This road is on the whole fo exceedingly good, as to render it paffable in carriages with great pleafure, for the country nearly all the way is very interefting.

\section{TanyBWleh,}

Below the Pafs, fo called from its being fituated on the brow of the hill overlooking the Vale of Ffefiniog, or more properly of Maentwrog, confifts only of a finall but comfortable inn, and an elegant manfion embowered in woods, the property of __. Oakley, efq. - This vale, watered by the little river Dwyryd, which meanders along its bofom, contrafted with the bleak and dreary mountains on the oppofite fide, from hence affords a moft pleafing profpect. A former traveller was fo highly gratified with the fcene, as to make the fingular remark, "That if a perfon could live upon a landfcape, he would fcarcely defire a more eligible fpot than this *."

The inn is a fmall but good houfe, occupied by, a very civil, attentive, and obliging man of the name Cartwright. A poft-chaife and four horfes are kept here.

* Wyndham's T'our through Monmouthrhire and Wales in the fummers of 2774 and 1777 . 
On the other fide of the vale ftands the church of Maentwrog, Tho Stone of 'T worog, fo denominated from a large ftone in the church-yard, at the northweft corner of the church. Twrog was a Britifh faint, who lived about the year 610 , and was the writer of Tiboeth, a romantic record belonging to St. Bueno, that was formerly kept in the church of Clynog in Cacrnarvonfhire.-Dr. Edmund Prys, archdeacon of Merioncth, who attained confiderable celebrity as a Welin poet, was rector of this place, and is faid to have been buried here. I fearched both the church and church-yard in vain for fome memorial of hini, and in my hopes of obtaining intelligence refpecting him from the inhabitants I was alfo difappointed.

I left Maentwrog, and inquiring the road to Harlech, proceeded on my journey. At the diftance of about half a mile, I croffed a fmall bridge. From hence, leaving the road for a while, I wandered along a foot-path up a wooded valley, for about a mile and a half, in fearch of a

\section{WATERFALL}

That had been defcribed to me, called Rhaiadr $D \hat{u}_{2}$ The Black Cataract. It was not without fome difficulty, and after much trouble in afcending and defcending the fides of the hills, that I found it. In this cataract, which is furrounded with dark and impending fcenery, the water is thrown with vaft impetuofity over three biack and fmooth rocks, 
each in a different direction. Of its height $I$ could form no idea, for the top of the upper fall, by the winding of the rocks, was not vifible from below. The rock tiat hangs immediately over the fall, was, from its great height and rude form, a fine object in the landfcape; and the whole of the hollow, to fome diftance below the cataract, was cextremely grand. I attempted to climb to the upper part, but the rocks were too perpendicular, and too flippery, to fuffer the attempt without danger. 'Therefore contenting myfelf with feeing as much as I could from below, I crofled the water, and crept along, but not without difficulty, on the fhelving rocks, by the fide of the ftream, for near half a mile. Here the banks clofed over my head, leaving but a narrow chafm, from which the light was altogether excluded by the dark foliage from each fide, and I found myfelf entering, to appearance, the mouth of a deep and horrid cavern. The fides were too fteep for me to entertain any idea of clambering up, and unlefs I chofe to fcramble back again to the cataract, I had no alternative but to penetrate the place. The darknefs, fortunately, did not extend far, and I foon found myfelf in a place where the bank was fufficiently floping to admit of my afcending to the meadows above; I was not a little pleafed in having thus eafily efcaped from this abode of horror.

Regaining the road I had left, it led me along the fice of Llynterwyn Ucha, The Upper Pool of 
Tecwyn, where I found the fcenery pleafant, though lefs mountainous than what I had paffed. This pool is larger than many of thofe in Wales, and its waters are beautifully clear. On one fide there is a range of low rocks, compofed of a Ahivery kind of flate, which had mouldered in many places to the bottom, in fmall tharp pieces, almof refembling needles.

Afterwards paffing the village of Llantecwyn, and Llyntecwyn Ifa, The Lower Tecwyn Pool, I came to a moft lorely little meadowy vale, about three miles diftant from Harlech, called (if I underftood the guide right) Doi Orcal. $\Lambda$ fter the late uncouth fcenery, I here enjoyed in the utmolt the pleafing effect of the green woods and meads of the vale, and the purple heath which concealed and foftened the harh colouring of the adjacent rocks.

, The whole of the walk from Beddgelert to Harlech I found exceedingly pleafant. From the continual varying of the fcenery, the attention was fully occupied during every part of the journey.The road from 'Tanybwlch is fcarcely paffable for carriages, but there is another from Beddgelert, at the ebb of the tide, over the fands: a guide, however, muft be taken who is acquainted with the track, as it is very unfafe for ftrangers to venturc alone. 
HARLECH,

Once the principal town in Merionethfhire, is now dwindled into an infignificant village, containing not more than four or five hundred inhabitants. It is in the parifh of Llanfair, and on the fea-coaft, near Cardigan Bay: the houfes and caftle are built on a cliff that immediately overhangs the marh. Not far from the caftle, there is an old rooflefs building, once the town-hall; in which, however, the members of parliament for the county continue ftill to be elected.

\section{Harlegeh Castle.}

This venerable ftructure is in tolerable prefervation. It is a fquare building, each fide meafuring about feventy yards; and has at every corner a round tower. From each of thefe iffued formerly a circular turret; nearly all now deftroyed. The entrance is betwixt two great rounders. The principal apartments appear to have been over the gateway, in a building which projected into the court; and at each angle of this building there is yet left a round tower. The caftle was defended on the eaft ficle by a deep fofs; and its fituation, on the verge of an almoft perpendicular rock, rendered it inpregnable in nearly every other part.-From the marth it is faid, except in fize, to bear a confiderable refemblance to the caftle of Belgrade in Turkey. 
On the evening that I arrived at Harlech, the atmofphere was fo perfectly clear, that I could very plainly diftinguifh the peaked fummit of Snowdon, elevated high above all the other mountains. The promontory of Llynu was vifible in aimoft every part; Criccieth caftle feemed fcarcely a mile difant; and the fine, though dangerous bay of Cardigan, lay entirely before me.

\section{History of Harlech Castle.}

The ancient name of this fortrefs was Twr Bronwen, Bronwen's Tower; fo called from Bronwen, the wibite neckcd, firter to Bren ap Llyr, duke of Cornwall, and afterwards king of Britain. She lived in the third century, and was the wife of Matholwch, an Irifhman. Her hufband one day, unfortunately, ftruck her a violent blow in the face, and the refented the outrage by inciting an infurrection among the people, and caufing a civil war. This blow is called, in the ancient Triads, one of the three evil blows of Britain; two others, of a nature nearly fimilar, being there faid to have produced fimilar commotions. Bronwen is fuppofed by fome to have refided here; and the higheft turret of the prefent caftle, though for what reafon I know not, fince this building was altogether founded many centuries after her tine, goes yet by the name of Bronwen's tower.

In the eleventh century this place took the name of Caer Colwyn, Collwyn's Fort, from Collwyin ap Tangno, 
Tangno, lord of Eivonead and Ardudwy, and one of the fifteen tribes of North Wales, who repaired the ancient caftle, and took it for his own refidence*. -The prefent name of Harlech is probably derived from the Britifh words hardd, beautiful, and llech, a rock, indicating its fituation.

According to fome of the ancient Britifh hif. torians, Harlech caftle was originally built, about the year $35^{\circ}$, by Maelgwn Gwynedd, prince of North Wales; and it is generally believed that Edward I. founded the prefent fortrefs or the ruins of the old caftle; fome parts of which are yet difinguifhable from the more modern work of that monarch.

The firft conftable, appointed in $\mathrm{I}_{2} 8_{3}$ by Edward, was allowed a falary of a hundred pounds per annum. This falary appears to have been afterwards reduced, for even when the fame perfon held the double office of conftable of the caftle and captain of the town, he ufually received only fifty pounds per annum; and when he had not the captainfhip of the town, he was paid but twenty-fix pounds, thirteen fhillings, and four-pence. Even fo lately as in the forty-fourth year of Elizabeth, the conftable received but fifty pounds per annum. The garrifon confifted of twenty-four foldiers $\dagger$.

* It is fometimes, though improperly, called, Caer Colun. See Camb. Reg. i. $4_{4} 8$.

+ Cotton MSS. in the Britifh Mufeum; Vitellius, C. i. 
In the year 1404, this caftle, along with that of Aberyftwyth in Cardiganfhire, was feized by the great, but ambitious Owen Glyndwr, during his rebellion againft Henry IV. They were both retaken about four years afterwards, by an army which the king had dipatched into Wales againft that turbulent chieftain *

Margaret of Anjou, the fpirited queen of Henry VI., after the king's defeat at Northampton in 1456 , fled from Coventry, and, narrowly efcaping the hands of lord Stanley, who difcovered and feized her jewels and baggage, found in this fortrefs an afylum from her enemies. She refided here but a little while, when the proceeded into Scotland, where collecting her friends, the marched towards Wakefield. At the lattor place the made an attack on the army of her enemy, the duke of York, which the routed; and the further fucceeded in deftroying the leader.

Soon after Edward IV. attained the Englifh throne, he found means to make himfelf mafter of every part of the kingdom, except this caftle and two or three others in Northumberland. Thefe he did not think it neceffary immediately to attack, in the expectation, probably, that when their governors faw the whole country continue in quiet poffeffion, they would of their own accord fubmit. The iden, however, proved groundileís, for David ap Ivan ap

* Carte, ii. 66r. and 66g. 
Einion, a ftaurch friend to the houfe of Lancafter, held out in this cafte nine years after the coronation of Edward, till I 468 . The king finding him ftill determined to refint, was at length compelled to fend an army againft him under the command of William Herbert, earl of Pembroke. The men with incredible difficulty marched over the heart of the Britifh Alps to the attack. On being fummoned to furrender, David returned for anfwer: "Some years ago $I$ held out a cafte in France againft its befiegers fo long, that all the old woinen in Wales talked of me: inform your commander that I will defend this Welfh caftle till all the old women of France thall hear of it.," The befieging army found the place altogether impregrablble, cxcept by famine, and fir Richard Herbert (brother to the earl), who had commanded during the fiege, was at laft obliged to compound for the furrender, by promifing the heroic Welfhman that he would intercede with the king for his life. It was therefore given up, and with it upwards of fifty gentlemen of rank, who had adhered to the Lancaftrian caufe. Thefe were all committed clofe prifoners to the tower; and when David was brought to the king, fir Richard, intreated that he might receive an unconditioned pardon, on the ground that it had been in his power, if he had chofen it, to retain the caftle confiderably longer, even in fpite of all the efforts of the Englifh army. The king refufed. "Then, Sire (faid fir Richard), you may, if you pleafe, take 
take my life inftead of that of the Welfh captain : if you do not, I will moft affuredly replace David in his cafte, and your highnefs may fend whom you pleafe to take him ont again." The king knew too well the value of a hero like fir Richard, to carry his denial any further* * David ap Ivan was pardoned, but his friend received no other reward for this perilous fervice $t$.

In the civil wars at the conclufion of the reign of Charles I., Harlech caftle was the laft in North Wales that held out for the king, being furrendered in March 1647 , to general Mytton, on honourable terms. At this time Mr. Wiliam Owen was the governor, and the garrifon confifted but of twentyeight men $\ddagger$.

The town of Harlech was made a free borough by Edward I., who confirmed to it feveral grants of lands and other emoluments.

\section{Mephitic Vapour.}

In the winter of 2694 , this neighbourhood was much alarmed by a kind of fiery exhalation, which came from a fandy and marhy trace of land, called

* Among other acts of heroifn in frr Richard Herbert, it is well known that he twice cleared his way in fafety, through a great Norman army, with only a battle-ax in his hand.

+ IVynne, 398. Slowe, 421. Carte, ii. 775. Life of lord Herbert, 8.

$\ddagger$ Whitelock, 243 . 
Morfa Bycinan, The Little Marfh, acrofs the channel eight miles towards Harlech: This injured much of the grafs in fuch a manner as to kill the cattle; and it fet hay and corn-ricks on fre for near a mile. from the coaft. It is reprefented to have had the appearance of a blue lambent flame, which by any great noife, fuch as the fring of guns, or the founding of horns, was eafily extinguifhed. All the damage was invariably done in the night; and, in the courfe of the winter, no fewer than fixteen hayricks, and two barns, one filled with hay, and the other with corn, were entirely deftroyed by it. It did not feem to affect any thing elfe, and men could go into it without receiving the leaft injury. It was obferved much more frequently during the firft three weeks than afterwards, yet it was feen, at different intervals, for at leaft eight months. The occafion of this fingular phenomenon is not exactly known. It appears mof probably to have arifen from fome collections of putrid fubfances, the vapour coming from which might have been directed towards this place by the wind; and yet it is fingular that, although the prevailing winds here are from the foith-weft, which ought to have blown it in a very different direction, it fhouli not have been obferved in other parts north of Harlech. Bifop Gibfon conjectured that it might have proceeded from the corrupted bodies of a great quantity of locufs which vifited this kingdom about that time, and were deftroyed by the coldnefs of the climate.

$\mathrm{He}$ 
He fays that a confiderable number of them had been feen lying about the fliores of Aberdaron, in Caernarronfhire *.

The public boufe at Harlech, for fuch it can only be denominated, is kept by a very civil man of the name of Anwyl. The provifions, at the time I was here, were homely, but the beds (only two, and thofe in the fame room) were clean and com. fortable.-The tourin, in inquiring for a gride, will find it worth his while to afk particularly for John Richards, a man who fpeaks Englifh fluently, is well acquainted with the ncirhbourhood, and, for his fituation, has a very fuperior underftanding.

* Lowthorp's Abridgement of the Philofophical Tranfaca tions, ii. 183 . Gibfon's Camden, 659. 


\section{( 15$)$}

\section{II A P. II.}

Excursion from Harlech to CwM Bychas.

Cylch Cyngrair, or Drusilical Circlis. - Crom Bychan,-Bwicls Tyddiad.-Drws Ardudwy. - Cw'm Nancoll.-Catarad.-Sarn Badrwyg. - Cantref Grvaelod, or overfiowed Hundred.-Cardi$\operatorname{san}$ Bay.

Conducted by Richards as my guide, I went from Harlech to explore an obfcure vale, about four miles diftant, called C:rm Bychan, The Little Hollow.

About a mile from the town, on a large elevated moor, he pointed out to me a circle of fmall ftones near thirty yards in diameter, with another at fome diftance, furrounding it. From its form and appearance, I am inclined to fuppofe that this was one of thofe

\section{Druidical, Circles}

In which were formerly holden the Gorfeddau, or bardic meetings. Thefe meetings were always in fome place fet apart in the open air, in a confpicuous fituation, and furrounded by a circle of ftones, having in the centre a larger one, by which the prefiding bard or druid ftood. There was here no relic of 
the middle ftone. This kind of circle was called Cylch Cyngrair, or the circle of congrefs. At thefe meetings, candidates were admitted to the different degrees of bardifm, and on thefe occafions it was that all the oral bardic poens and traditions were recited, and their laws fettled. During thefe ceremonies all the bards ftood within the circle, with their heads and feet bare, and clad in their unicoloured robes.

\section{CwM BrchaN}

Is a graffy dell, about half a mile in length, furrounded by fcenery as black and dreary as imagina. tion can draw. On the right of its entrance there is a fnall pool called Llyn $y$ Cwm Bychan, from whofe edge, Carreg y Saeth, The Rock of the Arrow, (from its being the ftation where the ancient Britifh fportfmen watched and killed the paffing deer,) towers the blackeft of all the vale.-I refted myfelf for a while on a rock above the pool, in a fituation whence I could at eafe obferve the rugged beauties of this romantic hollow. From hence the landfcape extended in all its magnificence: the vale was feen embofomed in ftupendous rocks, black and barren, and enlivened only by the patches of meagre vegetation lodged on their fhelving precipices.

We defcended into the hollow, and paffing there an ancient manfion, afcended on the other fide till we came to a deep mountain hollow called

BWLCE 


\section{BwLCH TYDDIAD.}

Here the rocks clofe, and oppofe a feries of thattered precipices, forming a fcene of defolation and barrennefs throughont. A few graffes, liverwort, and heath, conftitute all the regetation of this place. We wandered on this rocky cleft, for fuch it only feemed, till we got beyond the higher mountains, when, on a fudden, a fine open profpect of all the country eaftward was extended before us.' Here we were treated with a paitoral landfcape, bounded by high diftant mountains, which formed a majeftic barrier around: amongt thefe, Cader Idris, and the two Arrennigs, were particularly confpicuous.

\section{DRWG ARDUDWY.}

From hence we made a turn to the right, fill cantinuing our journey over a wretched horfe-path, and foon afterwards turning again to the right, we entered another deep glen called Drws Ardudwy, The Pafs of the Maritime Land, a place well calculated to infpire a timid mind with terror. The fides and bottom were almoft covered over with loofe fragments of Itone, once detached by the force of froft, or the irrefittible rufhing of torrents, after ftorms and heavy rain, from the heights above. The fear for perfonal fafety muft fometimes, in places fimilar to this, be accomranici with a tremor; for the mind is not always able to divelt itfelf of 
prejudices, and difagreeable affociations of ideass, and, in fpite of every effort of reafon and judgment, the unpleafing fenfations of terror will fometimes affect lis.

After this dreary fcene, we entered a more wide and fertile valley, called Cwm Nancoll, The Hollow if the finken Brook. From hence the guide took me, out of the ufual track, to fee a cromlech, in a farm called Gwern Einion. This cromlech is about two miles fouth of Harlech. It is at prefent made to form the corner of a wall, and is, on two fides, built up with ftones, to prevent the theep from getting through. There are fix fupporters, three about fix fcet, and the other three about four feet in height. The ftone that refts upon thefe is large, fat, and flanting.

\section{CATARACT:}

A little-while before we came to this cromlech, I heard, from the fide of the hill on which we were walking, the falling of water in a wood on the oppofite mountains, and apparently about half a mile from us. I could alio, notwithitanding the diftance, plainly perceive a filver line among the trees, formed by the ruhing of water down a precipice. The guide, in anfwer to my queftions refpecting it, faid that it was a cataract of no great height or brauty, and if it had a name he was not acquainted with it. My walk of this day had been very long and laborious, near twenty miles, 
over the moft ftony paths that I had yet feen in the country, and I was almoft fainting from want ef refrefhment: I was therefore, under the neceffity of being fatisfied with his account: In almoft any other cafe I fhould have croffed the vale to examine it, for I am convinced, from its appearance at fo great a diftance, that it muft have been a cataract of very confiderable height and beauty.

Betwixt the cromlech and the town of Harlech, I paffed another druidical circle, fomewhat fmaller than the one $I$ have before mentioned, but furrounded with a fimilar diftant circle.

As it happened to be about the ebb of the tide when we returned, the guide pointed out to me part of a long ftone-wall, which runs out into the fea from Mochras, a point of land a few miles fouth of Harlech, in a weft-fouth-weft direction for near twenty miles. 'This is called

\section{SARN BADRWYG,}

The Shiprurecking Cauferway. It is a very wonderfui work, being throughout about twenty-four feet thick. Sarn y Buch runs from a point north-weft of Har. lech, and is fuppofed to meet the end of this. The fpace betwixt thefe formed, fome centuries ago, a habitable hundred belonging to Merionethhire, called 


\section{Cantref Gwaelod,}

The Lozviand Hundred. The Wellh have yet tra: ditions refpecting feveral of the towns, as Caer Gwyddno, Caer Ceneder, \&c. Thefe walls were built to keep out the fea. About the year 500 , when Gwyddno Garan Hîr, Groyddno with the bigh Croan', was lord of this hundred, one of the men who had the care of the dams, got drunk and left open a flood-gate. The fea broke through with fuch force, as alfo to tear down part of the wall, and overilow the whole hundred, which, fince that time, has been always completely flooded.-Thus is Cardigan Bay, (a principal part of which Cantref Gwaelod formerly occupied,) for many miles fo full of thoals, as to render it extremely dangerous for a veffel of any burthen to venture at all near the Merionethinire conf. 


\section{(2I)}

\section{H A P. III.}

\section{Harlech to Barmouth:}

Itpright Stones. - Cromlechs. - Ancient Barrows, the Mode of forming, and the Utility of them. - Barmouth - Houfes fingularly firuated.-Inn._Beach, and River.-Uncommonly beautiful Siene. - Trade of Earmoutio.

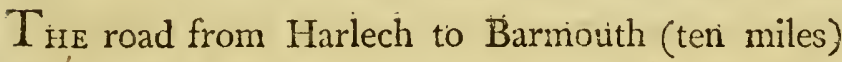
is even and good; but lying over a flat and difagreeable country, it is beyond meafure dull and uninterefting. At a diftance towards the fea there are nothing but turfy bogs and falt marihes; and; on the other fide, the mountains are low and ftony, and in every refpect devoid of picturefque beauty.

In a field by the road-fide, near Llaribedir, I obferved two upright ftones ftanding near each other, the one ten, and the other about fix feet in height. Thefe were without infcriptions; and are what the Welfh call Meini Groyr, "the ftones of the heroes;" or the funeral monuments of cele: brated warriors flain in battle.

A few hundred yards beyond the fifth mile fone; and at a little diftance on the left of the road, two cromlechs were pointed out to me. Thefe were very near each other, and placed on barrows, or 
heaps of loofe ftones, which are fuppofed to indicate that fome men of ancient note were interred beneath the:n. Thefe barrows, from the circumftance of the cromlechs being ereeted on them, are evidently of high antiquity; but I am inclined to fuppofe, (with a very judicious traveller through this country in the year 1774,) that many of the heaps of ftones with which this country abounds, and which are ufually taken for barrows, or carnedd, as they are here called, "were originally piled together for no other reafon than that the reft of the field might afford the clearer pafture. In the melancholy wate between Pont Aberglasllŷn and Llyn y Wenwn, I obferved many modern carnedds, which had been thrown up in large piles by the induftrious inhabitants for that profitable purpofe *."-The mode of forming the ancient carnedds in this country was fomewhat fingular. When the carnedd was confidered as the honourable tomb of a warrior, every one that pafied by threw on it an additional ftone as a mark of refpect; but when this heap became difgraced by Rielding the body of the guilty, it was ftill the cuftom of every one that pafted to fling his ftone, but, in this cale, it was done in token of deteftation.-The original intention of heaping ?tones over the dead, was doubtlefs to defend the bodies from being durg up, and devoured by the wolves, with which the wild and mountainous parts of Britain

* Wyndham's Tour through Monmouthnhire and Wales. formerly 
formerly abounded. It was a neceffary precaution, to prevent the friends of the deceafed from being thocked by the horrid fight of their carcafes mangled by thefe rapacious animals.

I paffed Cors $y$ Gedol, the ancient family feat of the Vaughans, but now the property of fir Thomas Moftyn, bart., and continuing my journey by Llanaber, foon afterwards arrived at

\section{BARMOUTH.}

This town is fituated in one of the moft unpleafant places that could have been chofen for it, near the conflux of the river Maw, or Mawddach*.Some of the houfes are built among the fand at the bottom, and others, at different heights, up the fide of a huge rock, which entirely thelters the place on the eaft. The fituations of the latter are fo fingular, that it is really curious for a ftranger to wind up along the narrow paths among the houfes, where, on one fide, he may, if he pleafe, enter the door of a dwelling, or, on the other, look down the chimney of the neighbour in front. The inhabitants might almoft cure their bacon in fome parts of this town, by the fimple procefs of hanging it out of their windows. The houfes at the foot of the rock are nearly choaked up with fand, which flls every

* From this river the town is fometimes called Aber Maw, The Conflux of the Marv. This was thortened into 'Bermaw, and corrupted to Barmouth. 
paffage, and is blown into every window that is for a moment left open. In rainy weather this fand, on the contrary, renders the place very dirty and unpleafant. The buildings are exceedingly irregular, and in moft inftances very bad. Notwithftanding all thefe difadvantages, Barmouth is frequented during the fummer feafon by many genteel families from Wales, and the wert of England, as a fea-bathing place. Its origin, as the refort of invalids, has been attributed to perfons frequenting the banks of this part of the river for the fake of the fcurvy. grafs, which grows there in abundance *.

The company muft neceffarily find it a molt uncomfortable place, for the inn (the Corfygedol arms); is at times almoft buried in fand, and no perfon can pofinty walk many yards without having it over his thoes. Were it not for the civility and friendly atrention of Mrs. Lewis, Barmouth would fail in its principal attraction.-I was beyond meafure furprized, on being introduced into the dining-room, to find, in this fecludied corner of the kingdon, upwards of thirty perfons, moft of them of fortune and fafnion. I found alfo, on inquiry, that this was by no means all the company at that time in the town; another large and good building, which MIrs. Lewis had in her own hands as a lodginghoufe, being allo quite full. To be thus fuddenly introduced, as it were, into the world, after my

- Sketch of the Hitory of Merionethfhire, by Mr. Robert Vaughan of Hengwrt. Camb. Reg. i. Igo.

folitary 
folitary rambles among the wilds of the country, was a very grateful incident; and I enjoyed the general cheerfulnefs and affability that prevailed, perhaps the more from its being entirely unexpected.

The lodging-houfes in the town, are many of them dirty and miferable places.-There are on the fands three bathing machines, but thefe are altogether appropriated to the ufe of the ladies, the gentlemen bathing on the open coaft. - The amufements feem to confift principally in going out in parties on the water, and in lounging on the beacl or the fands. - The beach is one of the mof delightful walks I ever beheld. The wide river Mawddacls winds amongt the mountains, forming many, and elegant promontories. Thefe rife to great heights on each fide, fome clad with wood, and others exhibiting their naked rocks, fcantily covered with the purple heath. The fummit of the lofty Cader Idris is feen to rife high above the other mountains, in the back ground. Fad the town been built here, fcarcely half a mile from its prefent fituation, inftead of one of the moft unpleafant, it might have been rendered one of the noft agreeable retirements in the kingdom.

Barmouth is the port of Wierionethinire; but it is not fo much frequented as it ought to be, on account of the inhabitants (who do not attempt commerce on a large fcale), vending their manufactures through the means of factors, who thus feize many of the advantages which the natives 
might enjoy. Mr. Pennant, however, informs us, that prior to the year 1781 , flannels to the value of $40,000 \%$, and ftockings to the value of $10,000 \%$, had been exported from hence in the courfe of a year.-The number of fhips at prefent belonging to the port is about a hundred : and the population of the place is eftimated at fifteen hundred. 


\section{$27)$}

\section{H A P. IV.}

\section{Barmouth to Dolgelie.}

The River Mazuddach. - Beautiful Scenerg.-Dolgelle.-Whimficai Defoription of Dolgelle. - Fuller's Enigmatical Defcription. Trade. - Inn.-Fortified in the Reign of Cbarles I.-Account of Places worth vifiting in the Neigbbourhood of Dolgelle.

I HAD already been highly gratified in my ramble along the beach for about a mile and a half from Barmouth; and, in my walk to Dolgelle, I retraced my fteps with additional pleafure. The Mawddach, ufually called Avon Vawr, The Great River, forms in this place a wide arm of the fea. It was now high water, and from the whole bed of the river being filled, the various fcenes that prefented themielves for fome miles were truly picturefque. The two firft miles, at the end of which I was compelled to leave the bank of the river, and proceed along the road, were, however, more interefting than any other part of the journey. In the compofition of the views, fcarcely any thing appeared wanting: there was every requifite of a fine landfcape, mountain and vale, wood, water, meadows, and rocks, arranged in beautiful order. The numerous heaps of peat fpread along the green bottom, were the only 
only unpleafing objects in the fcene, and thefe were eafily overlooked where every other object was fo beautiful.-Beyond the beach the road winds among the low mountains, at a little diftance from the river. From the openings or eminences I frequently faw the water, partly hidden by the intervening mountains, in which fituations it feveral times affumed the appearance of a beautiful lake.

From the village of Llanelltyd, about two miles from Dolgelle, there is a road which winds along a dark and gloomy vale towards Tanybwich; and at a little diftance a file is feen, from whence a footpath will lead the inquiring tourift, over the meadows, to the ancient monaftic ruin called by the Welfh Y Vanner, and by Tanner Kemmer Abbey. This will be defcribed in the enfuing chapter.

Many perfons prefer making the excurfion from Barmouth to Dolgelle by water. To fit at eafe, and enjoy without interruption the pleafures afforded by the picturefque fcenes along the Mawddach, muft doubtlefs be highly gratifying to an admirer of nature. The voyage, however, muft end at the diftance of about a mile from: Dolgelle, for here the river becomes fo greatly diminifhed, as not even to adnit a fmall pleafure boat any farther. The compaily munt therefore be contented to walk from thence to the town.

DoL。 


\section{Dorgeile,}

The Holme of the Groves, is a market town, in a commercial view, of fome importance, feated in a wide and fertile vale, between the rivers Arran and Wnion, and furrounded on all fides by high, and in many parts wooded, mountains.

A ftudent of Jefus College Oxford, who was a native of Dolgelle, was one afternoon drinking wine with fome of his college friends, when, in a ban. tering ftile, they afked what kind of a place it was that had been honoured in giving him birth: - "There," fays he, flinging on the table a handful of nuts, and fetting up a cork in the middle, "fuppofe each of thefe nuts a houfe, and that cork the church,-you will have fome tolerable idea of Dolgelle."

The analogy holds good, for the freets are as irregular as it is poffible to imagine them. The houfes in general are low, and ill built. The clucth, which is by much the neateft ftructure in or about the place, has in itfelf nothing that can attract particular attention. From various points of view on the cutfide of the town, the painter will, however, acknowledge, that it is not without its beauty.

We have a fingular enigmatical account of Dolgelle, written by Fuller fomewhat more than a century ago.

"1. The 
"I. The walls thereof are three miles high.

2. Men go into it over the water; but

3. Go ont of it under the water.

4. The thecple thereof doth grow therein.

5. There are more ale-houfes than houfes*:"

Thele five enigmas he folves in this manner: the firft, he fays, is explained by the mountains that furround the place. The fecond implies, that on one fide of the town there was a bridge over which all travellers muft pafs; and the third, that on the other fide, they had to go under a wooden trough, which conveyed water from a rock, at a little diftance, to an overthot mill. For the fourth, he fays, the belis (if plural) hung in a yew tree; and the $\operatorname{lo}\{$, that "tenements were divided into two or more tipling-houfes, and that even chimney-leis barns were often uied for that purpofe."-I prefume in this he alludes to the time in which fome fair was held, for the fale and exchange of the manufactures of the place. None of thefe remarks will apply at prefent, except the two firft.

There are at Dolgelle very confiderable manufactories of finnel, which, from the number of hands neceffarily employed, have rendered the place very populous, comparatively with other Welfh towns. 'The principal market for the goods is Shrewbury, but fo great a portion has of late been bought upon the fpor, that the inhabitants have had little occafion to find to a market at fuch a diftance.

* Fuller's Worthies of Walcs, p. 43.

The 
The beft $i n n$ is the Golden Lion, called likewife Plas Ifa, The Lower Houfe. The provifions, except the wine, I found good; but the bed into which I was put was intolerable.

During the civil wars of the reign of Charles I., about a hundred of the king's troops attempted to raife a fortification about this town. Mr. Edward Vaughan, however, at the head of a fmall party of the parliament's forces, attacked and routed them, taking prifoners the captain and feveral of the men *.

The neighbourhood of Dolgelle affords many interefting objects to the tourift. The fummit of Cader Idris, the celebrated Merionethfhire mountain, is not much more than fix miles diftant $\dagger$. A few miles towards the north, and at a little diftance from each other, are the three cataracts Rbaiadr D:, The Fall of the Cain, and The Fall of the Mawddach. Thefe will be defcribed in the next chapter. To all thefe places guides may eafily be obtained at Dolgelle.--The whole of the vale in which the town is fituated is remarkable for its picturefque fcenery, and beautiful views.

* TVhitelock, p. igo.

+ An account of Cader Idris will be found in chap. vi. 


\section{$\left(3^{2}\right)$}

\section{HAP. V.}

Excursign from Dozgelde to Kemmer Abbey AND THE WATERFALLS.

Y Vanner, ar Ken:mer Abbey. - Suffers from a Deception of one of the Monks. - The Cataradi at Dolmelynllyn. Difant Waterfall.T'Je Catarad of the Mawdldach. - The Calaral of the Cain. Guide.

Tye three cataracts mentioned in the conclufion of the laft chapter, Rbaiadr $D \hat{u}$, in the grounds of W. A. Madocks, efq. of Dolmelynllyn, the Foll of the Cain, and the Fall of the Mawddach, are all near the road leading from Dolgelle to Tanybwlch. The former is about fix, and the other two are about nine miles difant from Dolgelle.

\section{Y VANNer, OR KeMMER ABbEY.}

In my expedition to thefe waterfalls, I procecáed near a mile and a half along the road, when, (a few hundred yards before I reached the bridge at Llaneiltid,) I left it, and went on a foot-path to the right. This led me over fome meadows, for about a quarter of a mile, to an avenue of fycamores, and thence to the remains of an abbey, not vifible from 
the road, called by the Wellh, Y Vanner, and by the old writers, Kemmer abbey*.

Where pious beadfmen, from the world retir' $d$,

In blifsful vifions wing'd their fouls to heav'n, While future joys their noblet tranfports fir'd,

They wept their erring days, and were forgiv'n.

The prefent remains of this monaftery have little intereft for any but the antiquarian: they are altogether devoid of ornament or elegance, and from no point of view are in any degree picturefque. Part of the church only is left, and the fpace of ground it occupies is very inconfiderable. The ruins of the refectory and the abbot's dwelling, form part of the walls of an adjoining farm-houfe. The other parts are much fhattered, and the farmer, in whofe ground the building ftands, has patched them in many places with modern mafonry, to render them of ufe in his bufinefs. The length of the church is betwixt thirty and forty yards, and the width not more than eight or nine. The eaft end is more perfect than any other part, and, through its thick covering of ivy, I could difcern three fmall lancet-fhaped windows. Againt the fouth-wall there are a few fmall gothic pillars and arches; and in the wall an aperture where probably the holy water was kept. In this part of the build. ing, oppofite to two fmall arches, there has alfo

* Or, varioufy, Cymmer, Cymnar, Cwmner, Kinner, Kin. mer, and Kyumer Abbey. Kymer, in the ancient Brition language, fignified the meeting of two or more rivers.

VOL. II.

D

been 
been a femi-circular door; and, near this, there is the mutilated head of a human figure. A large plane-tree is now growing from among the ruins of the wert.cnd of the building, whence it fhould feem to have long been in a ruined ftate. From the obfcurity of its fituation, and the want of that kind of elegance ufua! in monaftic ruins, this abbey is fcarcely known even at Dolgelle. The tourif will inquire for it in rain as Kemmer abbey, for the Well people in general know it by no other name than that of $Y$ Yanner.

It was founded about the year 1200 for fome monks of the Ciftercian order, from Cwm Hir abbey in Radnorfhire, by Meredith and Griffith, the fons of Cynan ap Owen Gwynedd, prince of North Wales*. "This feems (fays a Wellh writer) to have becn a colony of monks, fent off by that monaftery, as bees do when the hive is too full t."

About thirty years after the fuppofed period of its foundation, Kenmer abbey appears to have been in a flourifhing ftate. At this time, when Henry III. was marching againf the Wellh, who had rifen, under their prince, Llewelyn ap Iorwerth, and

* Vaughan's Sketcl of Merioneththire. Cam. Reg. i. Iود. 'Tanner's Notitia Monaftica.

† Letter of Lewis Morris. Cam. Reg. ii. 493. This feems to account for Dugdale's miftake in confounding this abbey with that of Combehire, or Cwm Hir, in Radnorfhire. In the Parcolude Annals, Combehire is confidered the mother abbey to Fimmer. 
attacked the caftle of Montgomery, one of the monks of Kemmer happened to be near, and was queftioned as to the fituation and ftrength of the Welih army. He confidered it a duty to befriend his country, rather than affit an enemy, and therefore deceived then fo much by his report of the ftate of the oppofing forces, that Henry determined on an immediate attack. The Wellh, at the firft onfet, feigned a retreat to a neighbouring marfh. The Englifh foldiers, incumbered as they were with their armour, without hefitation, plunged after them, and, as foon as the enemy faw that the greater part were in the marfh, and unable either to act offenfively or to retreat, they returned upon them with fo much fury, as, after a fhort conflict, to come off victorious.-This deception naturally enraged the king, and, not long afterwards, as he'paffed the abbey with his, army, he ordered the monaftery to be fet on fire and deftroyed. All the out-offices were confumed, but the abbot faved the reft of the building by his entreaties to the king, and paying down a fine of three hundred marks*.

At the diffolution of abbies, the revenues of Kemmer were eftimated at betwixt fifty and fixty pounds a yeart. The fite remained in the crown till the reign of queen Elizabeth, who, about the year $57^{8}$, granted it to Robert, earl of Leicelter. In

- Powel, 287. Matt. Paris, 31 r.

+ Tanner's Notitia; and Dugdale's Monaticon.

D 3

what 
what manner it has fince defcended, we have no information.

On a bank not far diftant, there was formerly a Britifh fortrefs called Caftéll Cymmer, The Caftle of the Conflux. This was demolifhed about the year III 3 , not long after its erection, by the fons of Cadwgan ap Bleddyn, on fome difagreement with the founder; and it is fuppofed to have never been rebuilt *.

Returning from the abbey to the road, I croffed the bridge at Llanelltil, and proceeded along the vale leading towards Tanybwlch. The firtt waterfall the guide brought me to was

\section{RhaiAdr Du,}

The Black Cataract. This, as I have before faid, is in the grounds of W. A. Madocks, efq. at Dolmelynllyn, whence it is often called the Dolmelynllyn Fall.-The water foams, with a thundering noife, down two rocks about fixty feet high. The fcene has a fingular appearance from the black adjacent and uncouth rocks being in many places covered with a pure white lichen. The trees on one fide of the ftream had been lately cut down, but the lively and varied green and brown tints of the other were beautifully contrafted with the almolt jet black rocks

* Powel, 183 .

with 
with which they were intermixed. The torrent rolls into a fmall deep bafon, from whence it dafhes itfelf along the rugged channel to the river Mawddach, which flows at no great diftance.-Mr. Madocks has been at the expence of making a good foot-path, both to the bottom, and to the upper part of this cataract, by which the traveller is enabled with comfort to fee it to the greateft advantage.

I went about a mile farther on the road, from whence I had a walk, of near two miles, along a foot-path to the right, to the remaining waterfalls, which are within a few hundred yards of each other. From the fide of an eminence about half a mile from thefe, I could obferve the river Mawddach rolling down a fteep, in a woody vale above, and its hoarfe murmuring juft reached my ear. Beyond it, at fome diftance, there was a rude arch, which croffed the glen, and from my ftation gave a pleafing and romantic caft to the fcene.

Defcending now (but cautious left too faft, )

A fudden fteep upon a ruftic bridge,

We pafs a gulph in which the hazels dip

Their pendant boughs.

This was a perfectly alpine bridge over the river Cain, formed by the rude trunk of an oak which hung frightfully over the black torrent, that roared amongit the rocks many feet beneath. I had not paffed this bridge far, before I found myfelf at the foot of Rhaiadr y Mawddach.

D 3

THE 


\section{The Cataract of the Mawddach.}

The river here forces itfelf down a rock betwixt fifty and fixty feet in height, whofe ftrata lying in parallel lines feveral degrees inclined from the horizon, give the fcene a fingularly crooked appearance. The ftream is thrice broken in its defcent, and the bafon into which it is precipitated is very large. The rocks and trees form an amphitheatre around, and the foreground was finely broken by the large pieces of rock that had been once loofened from above. I had to crofs the ftream before I could fee the upper part of the fall, which was hidden by intervening rocks. In this ftation the fcene appeared complete, and it was certainly picturefque.

\section{Pistyll y Cain *,}

The Spout of the Cain, is by far the highert and moft magnificent cataract of the three. A narrow ftream rufhes down a vaft rock, at leaft a hundred and fifty feet high, whofe horizontal ftrata run in irregular fteps through its whole breadth, and form a mural front. Thefe, indeed, are fo regular, as in a great meafure to deftroy the picturefque effect of the fcene, unlefs they are nearly hidden by a much greater volume of water than ufual. Immenfe frag.

* The word $P i l_{y} l l$, in the Welh language, fignifies a narrow ftream of water, fomewhat refembling that which iffues through a fgout. 
ments of broken rock at the foot of the fall, feattered in every different direction, communicate a pleafing effect; and the agrreeable mixture of tints of the dark oak and birch, with the yellower and fading $\mathrm{dm}$, formed altogether a highly pleafing fcene.

My guide to the waterfalls, was an Englifhman, who keeps a fmall public houfe near Dolmelynllyn. His name is Bartlet. He has refided in Wales only a few years, and is yet fcarcely able to fpeak the language of the country. 


\section{$(40)$}

\section{H A P. VI.}

Dolgelle to Machynleter.

View of the Country around Dolgelle. - The Pool of the three Pebbles; and Tradition refpecting the enormous Giant Idris. T The Blue Lion, and Edruard Fones. - Afcent to the Summit of Cader Idris. Account of Idris.-Cafcades.-Llyn y Cae.-Proppect from the Summit of Cader Idris. - Cataract near the Blue Lion, - Machynlleth. -Mr. Aikin's Defcription of the Devil's Bridge, near Havod in Cardiganßire.

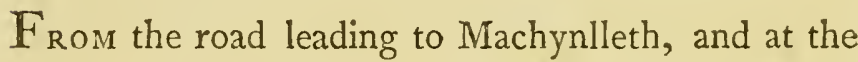
diftance of about two miles, the town of Dolgelle is feen to greater advantage than from moft other points of view. It appears in the midft of a vale replete with paftoral beauty. The wide river Mawddach in the diftance, reflects its filvery whitenefs in the bofom of high and dreary mountains. The intervening fpace exhibits luxuriant woods, mea. dows, and corn-fields, interfected by the river Wnion, which ferpentizes along the vale.

The road now paffes over high and fwampy moors, and for fome miles the fcenery is wild, dreary, and comfortlefs. The lofty Cader Idris, its fummit ob. fcured in clouds, formed the entire boundary of thefe wilds towards the fouth-weft. 


\section{The Pool of the Three Pebbles,}

This is a fmall pool on the left of the road about five miles from Dolgelle. The Welfh call it Llyn Trigrainauyn. It has its name from the three huge fragments of rock that are feen by its fide, which the traditions of the peafantry affert to have been what the giant Idris called three pebbles. This huge man, from whom the adjacent mountain had its name, was one day walking round his poffeffions in thefe mountains, when, fays tradition, he found fomething had fallen into his thoe that began to hurt his foot. He pulled it off, and threw out thefe three pebbles, after which he experienced no further inconvenience! One of thefe pebbles is about four and twenty feet long, eighteen broad, and twelve high.--So much for tradition!

The pool is believed to be bottomlefs; but, though this is not the cafe, its depth for fo fmall a furface of water is uncommonly great, being, as I was told, upwards of fifty fathoms.

I had not got far beyond this pool, when I found the profpect become fomewhat interefting. A pleafing vale now prefented itfelf, which inclofes a pool about a mile in length, called Llyn Mwyngil, The Lake of the Pleafant Retreat. This is bounded by hills. 


\section{The BLue Lion.}

As I was anxious to afcend Cader Idris, and, although the weather had become very unfavourable, as I fhould lofe all opportunity of doing it if I proceeded any farther at prefent, I lopped at the Blue Lion, a fmall public houfe, a little beyond the pool of the Three Pebbles. It had begun to rain very hard a little before, my arrival, and, as it was then late in the day, I determined to remain here all night, in the hope that before morning the weather might clear up. Not having yet dined, I inquired what I could have to eat, but found, as Dr. Johnfon did at Glcnelg, in the Highlands of Scotland, that, "of the provifions, the negative catalogue was very copious." I could have no meat (except bad bacon), no eggs, no wine, no firits. It was needlefs to inquire further into what I could not have, I therefore directed the good woman of the houfe to bring me any thing that was eatable. Bread and butter, and new ale, taken evidently from the tub in which it was fermenting, conftituted there. fore my principal fare at this cottage for two days. I have had occafion to remark, through both my journies, that the ale is generally drank within a few days of its being brewed, at moft of the fmall inns in Wales. The labouring people fee it taken from the tub with unconcern, and feem to relifh it as much, while fermenting, as they would if it was drawn from the cafk. If it has but the name of 
Crurie, they confider its quality a very fecondary object. How far this may be injurious to their health, I am not able to fay, but the general poverty of the loweft clafs of the people here is fo great, that it is not probable they will ever have their ale of much better quality.

The landlord of the Blue Lion, if I may dignify him with that appellation, is a fchoolmafter, a guide, and a cutter of grave-ftones, and to his various other qualifieations, he adds a very confiderable tafte for-ale, as the following memoranda of my cheap living at this houfe will thew:

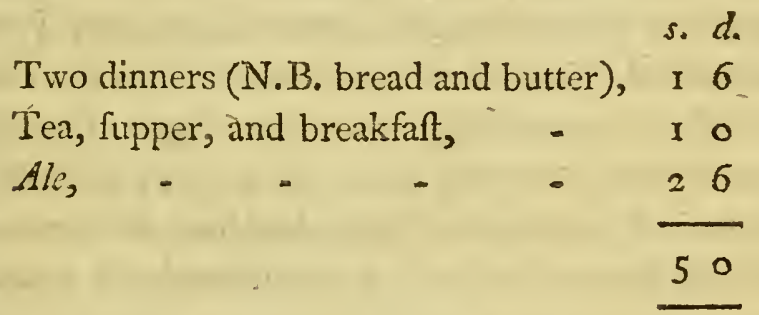

This man, whofe name is Edward Jones, I found fomewhat too talkative, particularly on the fubject of his own qualifications. I obtained from him nuch of the news of the neigbourhood, but little information on which I could rely refpecting the country. I fmiled feveral times at his efforts to fhew off his learning and talents, thefe, however, in fo obfcure a fituation, were perhaps excufable.

This houfe is fituated by the road fide, immediately under Cader Idris, and is a very convenient place from whence travellers, coming from Machynlleth, 
ynlleth, may afcend that mountain. If it is not found inconvenient, on account of carriages or horfes, they may go over the fummit, and down the other way to Dolgelle: this they would do in nearly as fhort a fpace of time as it would require to defcend again to the Blue Lion.-The bed I flept in was not a very bad one, nor was I here, though in a fmaller houfe, fo peftered with fleas, as I had before been at Beddgelert.

Ascent to the Summit of Cader Idris,

The morning proved more favourable than I expected; and although it was ftill cloudy, I was determined to venture on an excurfion to the fummit of the mountain, under the hopes that the weather might entirely clear up before I arrived at the top. About nine o'clock, therefore, in company with my loquacious hoft, I commenced my expedi. tion.

I have faid that this mountain had its name from a perfon called Idris, fuppofed by tradition to have been an enormous giant. The old bardic writings, however, rather reprefent him great in mind than ftature: in thefe he is faid to have been a poet, an aftronomer; and philofopher. He is fuppofed alfo to have been a prince of thefe parts; but the period is fo remote, that little more than his name and talents are now to be afcertained *. Cadair Idris,

- He is fometimes called Cazur Idris, or king Idris, Cazur being an old Weilh word for king. 
or the feat of Idris, is thought to imply that he had an obfervatory, or ftudy, on the fummit of the mountain. Thefe fuppofitions, however, feem founded on a very uncertain bafis.

There had been much rain during the night, in confequence- of which the guide took me along the fide of a rivulet, which flows from one of the hollows above, to fee a fmall cataract. The torrent was thrown down the face of a fteep rock in a white theet of foam, thrice broken in its defcent. It might perhaps be more properly denominated a cafcade, for, although it was extremely pretty, it was on fo fmall a fcale, as to be devoid of much of the grandeur that is ufual in waterfalls that boaft any degree of picturefque beauty.-Above this, on the fame ftream, another ftill more fmall and contracted was pointed out to me. The height of the latter rock was not more than feven or eight yards, and the whole fcene would have appeared very trifling, had it not been ornamented by three majeftic oaks, whofe branches, whilft they almof concealed the ftream, added greatly to its beauty.

Croffing the rivulet, I went for a little way along its bank, and was much pleafed with feveral other cafcades that were formed in its defcent. After a while 1 arrived in the mountain hollow, that contains the waters of 


\section{LLYN Y CAE*,}

The inclofed Pool, from the wert fide of which rifes a ftupendous, black, and precipitous rock, called Craig $y$ Cae, that cafts a gloomy thade on every thing below it, and throws upon the water its own difmal hue. Its fullen and majeftic front was enlivened only with patches of the mors faxifrage, and a few goats, that were feen fkipping carelefsly among its dangerous fteeps. From its fpiry points and deep precipices, it has affumed an appearance that fomewhat refembles the age-worn front of a maffy ancient cathedral. The whole of the fcene, from near the edge of the pool, was truly picturefque and grand.

Whillt I was gazing at the rock, a thower of rain fo fmart came on, that in a fhort time my clothes were wet through. Soon after this the clouds rofe above the lower parts of the mountain, and the higheft peak alone was clouded. - The fummit is called Pen y Cader, The Head of the Scat. This, like that of Snowdon, is conical, and covered with loofe ftones. With the utmoft patience and compofure, I waited on this point, enveloped in mift,

* "Some travellers have mentioned the finding of lava, and other volcanic productions here: upon ftrict exanination, how. ever, we were unable to difcover any thing of the kind; nor did the water of the lake appear to differ in any refpect from the pureft rock water, though it was tried repeatedly with the moft delicate tefts." Aikin's Tour through North W'ales, p. 62. 
for more than half an hour, when, for about ten minutes, the mountain became perfectly cleared. I had from hence a view, if not more extenfive, I think more varied, than that from Snowdon. On one fide the mountain formed an abrupt and deep precipice, at the bottom of which a fmall lake or two were lodged. The diftant views were of Bala pool, and its adjacent mountains, and beyond thefe - of the long range of Ferwyn mountains, headed by Cader Ferwyn. Towards the fouth lay the county of Montgomery, which, with its celebrated mountain Plinlimmon, feemed almoft immediately under the eye. On the weft fide I had the whole curve of Cardigan Bay, from St. David's entirely round to Caernarvonfhire. I had farcely looked round, when the gathering clouds fwept over me in deeper folds, and all was again hidden from my fight.

The afcent to the fummit of Cader Idris is much more eafy than that of Snowdon; and I am confident that from Jones's houfe I could attain the higheft point in about two hours. - The perpend: cular height of this mountain, meafured from the green near Dolgelle, is but $95^{\circ}$ yards*.-Cader Idris has three high points, the moit lofty is called $P \mathrm{Cn} y$ Cader; the next in height Mynydd Moel; and the other Craig y Cae.

In defcending $I$ took a direction eaftward of that in which I had gone up, and proceeded along that 
part of the mountain called Mynydd Mocl. The path in this direction is fufficiently floping to allow a perfon to ride even to the fummit. A gentleman, mounted on a little Welfh poney, had done this a few days before I was here.

At the bottom of a hill on the right of the road leading to Machynlleth, and about half a mile from the Blue Lion, I faw another fmall cataract, which, although fcarcely more than feven or eight yards high, was by no means deftitute of beauty. The rock is five or fix times as wide at the top as it is below, which gives to the fcene a very fingular effect. In dry weather I fhould think this would be in want of water: after a heavy fhower of rain it may, however, be always feen in perfection.

The road from Jones's cottage to Machynlleth is very level and good; but as I had rain nearly the whole way, and as it lies along a narrow hollow, between a feries of wooded mountains, without much variety of character, even this hort journey was rendered very unpleafant. The murmuring of the rivulet, which accompanied me for fome miles, and here and there a picturefque cottage, feated in the woods, chiefly occupied my attention, till I had arrived within two miles of Nachynlleth. Towards evening the rain ceafed, the clouns difperfed, and the fine vale in which the town ftands appeared exceedingly beautiful. Machynlleth is hidden from 
the obferver in this direction, by intervening mountains, till he is arrived within about a mile of it; and it is firft feen on a fudden turn of the road at a little diftance from the river.

\section{Machynlleth *}

I croffed the Dovey, and fhortly afterwards ar. rived at Machynlleth, a neat, and a much more regularly built town than moft in Wales. The town-hall is a plain unadorned ftructure; and the church (a common fault in this country) is whitcwafhed. From the church-yard there is a pretty view along a green and meadowy vale.-Machynlleth is a place of fome trade, and it has an air of greater opulence than moft of the Welfh towns.

An ancient building, conftructed of the thin fhaly ftone of this country, and now converted into fables, was pointed out to me as that in which Owen Glyndwr fummoned the chieftains of Wales in the year 1402 . He was here acknowvledged their prince, and as fuch proclaimed and crowned $\dagger$.

It is highly probable that this town was the fite of Maglona, the principal Roman ftation in Montgomeryfhire. Near Penallt, about two miles diftant, there is a place called Cefyn Caer, The Ridge of the City, where Roman coins have frequently been

* This word implies the plase near the river Cynllaetb, which was the ancieni name for the Dovey.

+ Wynne's Hiftory of Wales, $32 \mathrm{x}$. Carte, ii. 655 .

yOL. IX. 
fourd, and where there has once been a fmall circular fort *.

When on the point of fetting out from Machynlleth to Llanydloes, I was informed of a lofty cataract, near a pool called Llyn Pen Rhaiadr, The Pool at the Head of the Cataract, about fix miles diftant; but, as the road lay entirely over the mountains, and I was defirous to reach Llanydloes as foon as poffiblc, I did not take the trouble of vifiting it.

If I had not (that I might confine my attention altogether to North Wales, and give to it all the time I had to fpare) entered into a refolution not even to fet my foot in the fouthern divifion of the principality, I fhould have gone from Machynlleth to

\section{Áberystwyth,}

'The Conflux of the Iftwyth, diftant about nineteen miles. This is now a celebrated fea-bathing place, frequented by much company.-It has the remains of a caftle, founded at the commencement of the twelfth century by Gilbert Strongbow, but about two centuries afterwards rebuilt by king Edward $I$.

From hence I fhould have proceeded to an inn, about twelve miles off, called the Havod Arms, not

- Camden. Vaughan's Merionethhire, in Cam. Reg. i. 189 . 
far from which is the celebrated bridge called Pont ar Monach, The Bridge over the Monach, and by the Englifh, The Devil's Bridge; and from this place I fhould have returned into North Wales near Llanydioes. - The excurfion altogether would not have been more than fifty miles, and the twenty miles of unpleafant road betwixt Machynlleth and Llanydloes I fhould by this means have avoided.

\section{The Devil's Bridge.}

As, however, it may be ufeful to fome future traveller in this country, I thall tranfcribe the fhori defcription of the Deril's Bridge, and the deep glen over which it is built, from an interefting journey through North Wales by Mr. Aikin. It is the only account on whofe accuracy I could rely *.

"After a long, and rather tedious walk (frem Aberyltwyth), we came fuddenly to a molt fingularly ftriking fpot. The valley of the Rhydol contracts into a deep glen, the rocky banks of which are clothed with plantations, and at the bottom runs a rapid torrent. This laads foon to the fpot that we were in fearch of, which is full of horid fublimity. It is formed by a deep chafm, or cleft, between two rocks, which juft receives light enough to difcover at the bottom, through the tangled thickets, an impetuous torrent, which is foon loft

* Journal of a-Tour through North Wales, and part of Shrophire. Crown 8vo. Lond. 1797. 
under a lofty bridge. By defcending an hundred feet, we had a clearer view of this romantic fcene. Juft above our heads was a double bridge, which has been thrown over the gulph; the inferior bridge was built by a monaftery, and hence called Pont ar Monach; this growing to decay, and being thought infecure, another arch was thrown directly above, and refting on the ancient one, and which now fupports a grood road acrols the precipice. The water below has fcooped out feveral deep chafms in the rock, through which it flows before it dives under the bridge. A large beech has flung its boughs horizontally over the torrent, as if to hide it from the fpectator; and the whole banks of this wild fpot are rough with fern, mofs, and native thickets, except on one fide, where a perpendicular naked flate-rock lets in the light to the inmoft receffes. Having fufficiently admired this tremendous fcene, we walked along the cliffs overhanging the deer glen, which receives the mingled waters of the Rhydol and Monach, whofe luxuriant woods almoft concealed the numerous rapids and falls occafroned by the ruggednefs of its rocky bottom. After a troublefome, and rather a hazardous defcent, forcing our way through the trees, and acrofs two or three headlong little freams, we arrived at a rocky bank, a few feet above the river, command. ing a fine view of the junction of the Rhydol and Monach, which feem to vie with each other in the turbulence of their waters, and the frequency of their 
their cafcades. Immediately above the union of the two torrents, rifes a perpendicular rock, on the crags of which we faw feveral kites perched; the fummit of the rock is crowned with wood, equal in luxuriance to that which clothes the lofty fides of the glen." 


\section{$(54)$}

\section{H A P. VII.}

Machynlleth to Lianydoes.

Account of the MTountain Flynlinmon. - The Source of the Severn.Calaract. - Llanydlocs.

$T_{\mathrm{HE}}$ diftance from Machynlleth to Llanydloes is about twenty miles, and the road lies over a feries of dreary and barren moors. The mountains here have no one character of beauty, and during my whole walk I fcarcely faw a fingle tree: The only pleafing objects were a few patches of corn, fpa ringly fcattered in different parts of the adjacent bottoms.-I had proceeded about five miles, when I arrived at the foot of a lofty hill, along which the road continues on an afcent for near three miles. From the top I had an ample view of all the country around me; but its beauties were very few, it feemed little more than one difmal wafte of hill and vale.

Proceeding on my journey, the Montgomeryfhire mountain

\section{Pliyilimmon}

Became vifible at the diftance of four or five miles on the right. Its name appears to have been derived from 
from Pen Lummon, The Summit of the Beacon, from its being fo much higher than all the furrounding hills. This fuppofition is aided by the circumftance of its being of the utmoft ufe to the peafantry of the adjacent country, even when the ground is covered with fnow, as a known mark by which they are enabled to fteer their courfe*.-From the various accounts that had reached me refpecting this mountain, there did not appear any probable compenfation for my trouble in going fo far out of iny road to afcend its fummit, I therefore continued my route, and only paffed it at a diftance.-The adjacent mountains being all low, render Plynlimmon much higher in appearance than it really is: from this, and its giving birth to three noted rivers, the Severn, the Wye, and the Rhydol, it feems not improbable that it originally obtained its celebrity. In perpendicular height it is far exceeded by Snowdon, Cader Idris, and many other mountains of the principality.

\section{The Head of the Severn.}

The manufcript journal of a very intelligent friend has furnifhed me with the following fhort account of

- The following are conjectures by Mr. Lewis Morris refpeeting the derivation of Plynlimmon.-From Plymnzoydd a battle, and Lluman a ftandard or banner: thus making Plymnlluman. Or elfe from Blaen a corner, or the convexity of a hill, and Llymyfen, or Llumanes, a kind of hawk : Blacn Llumanes, the point where thefe hawks refted. Letter of Lewis Morris to Dr. Phillips, depofited among the Plâs Gwynn MSS. 
the fource of this celebrated river. The Severn rifes from a fmall fpring on the fouth-eaft fide of Plynlimmon, and nearly at its fummit. The water iffues from a rock at the bottom of a kind of large hole, whofe fides are formed of peat. The ground around the edges is fomer:hat elevated. A ftream fo fmall iffues from this place, that a child four years of age might ftride acrofs it. The water, which is of a red colour, is very unpleafant to the tafte.Thofe perfons who wifh to trace the Severn to its fource, are directed to keep the right-hand fiream all the way up the mountain.

In the flat country, betwixt Plynlimmon and the road, I obferved a fmall unadorned pool called Glâs Ilyn, The Blue Pool.

\section{Cataract'}

IIaving proceeded about half-way to Llanydloes, I was directed to leave the road, and go a mile and a half fouth, to fee a cataract called Frwd y Pennant, The Torrent at the Head of the Vale. The rock was nearly perpendicular, and the water, then in plenty, from the late rains, roared down its lofty front with a deafening noife. The fhrubs hanging from the adjacent rocks added to its beauty. This waterall is exceeded in height by few in North Wales.

About four miles from Llanydloes, the appearance of the country began to change, and the woody vales 
sales in front, with the little Llyn yr Avange, Beaver's Pool, at a diftance among them, formed on the whole a pleafing fcene.

\section{LLANYDLOES.}

The entrance into Llanydloes, The Church of St. Idlos, is over a long wooden bridge acrofs the Severn. This was fuch as not to prepofier's me in favour of the town. The ftreets are wide, but the houfes are principally formed by means of timber frames, with their intermediate fpaces clofed with laths and mud. Thefe in general are very irregular, and I found a greater fcarcity of good houfes in this place than in any of its fize and confequence that I had yet vifited. -The town-houfe is a wretched building, conftructed much in the manner of the dwelling-houfes.

The width of the ftreets of Llanydloes is (very fingularly) a great inconvenience, for the inhabitants throughout the town, taking advantage of it, accumulate all their afhes and filth in great heaps before their doors. Thefe heaps are, indeed, fo large, that in a hot day the exhalation of noxious vapours from them, as I have experienced, muft be an abominable nuifance to every perfon accuftomed to cleanlinefs.

The town is built in the form of a crofs, having the market-houfe nearly in the centre.-The church is remarkable only for having fix arches, with columns furrounded by round pillars, ending in capi- 
tals of palm-leaves. The inhabitants affert that thefe were brought, fome time after the diffolution, from Cwm Hir abbey in Radnorfhire.

In Llanydloes there is carried on a very confiderable trade for yarn. This is manufactured into flannels, and fent to Welfh Pool for fale. 


\section{H A P. VIII.}

\section{Llanydloes to NewTown.}

Vicw of the Country. - Anecklote of Edward Herbert, Efq-Nerwtozun.-Catarait.-Cagell Dolforzuyn.-Hifory of this Fortrefs. -The Story of Salrina, and the Origin of the Severn.

$\mathrm{O}_{\mathrm{N}}$ my leaving Llanydloes, I foon began to find myfelf in a kind of country that plainly indicated an approach towards England. The road winds along a vale much flatter, and more highly cultivated, than any in the interior of Wales. I faw here feveral fields both of rye and wheat, two fpecies of corn feldom grown in mountainous countries: the winds and ftorms are there fo violent, that they would fhake out the grain from the ears before it could ripen.-I now wandered

On the gentle Severn's fedgy bank.

The river was here but a few yards acrofs, and it glided filently and fmoothly along, reflecting brightly the green impending foliage of its banks.

Fields, lawns, hills, vallies, paitures, all ippear

Clad in the varied beauties of the year.

Meanu'ring waters, waving woods ale feen

And cattle fcatter'd in each diftant grcen.

The curling fmoke, from cottages afcerds,

There towers the hill, and there the valley bends.

I parfed 
I paffed Llandinam, a fmall village, about feven miles from Llanydloes, which I mention only for the purpofe of relating an anecdote of the valour of Edward Herbert, efq., the grandfather of the celebrated lord Herbert of Chirbury. This gentleman was a ftrenuous oppofer of the outlaws and thieves of his time, who were in great numbers among the mountains of Montgomeryfinire. In order to fupprefs them, he often went with his adherents to the places which they frequented. Some of them having been feen in a public houfe at Llandinam, Mr. Herbert, and a few of his $f \leqslant r v a n t s$, procecded thither to apprehend them. The principal outlaw aimed an arrow at him, which ftruck his faddle, and fuck there. Herbert, with his fword in his hand, and with undaunted courage, galloped up to him, and took him prifoner. He pointed to the arrow, requefting the fellow to obferve what he had done. "Ah! (replied the man,) had not my beft bow been left behind, I fhould have dons a greater deed than fhoot your facldle." He was tried for the crime, found guilty, and hanged *."

\section{MEWTOWr.}

In Newtown, or, as it is called by the Welfh, Tre-Nerwydd, I found nothing remarkable. It is a clean, and rather neat place, and the furrounding country is fertile and pleafant.-The manufcript

* Life of lord Herbert, 5 . 
journal of my friend, quoted in the laft chapter, contains the following memorandum refpecting the church. "This building has a fereen, faid so have been brought from fome neighbouring abbey. It may be antique, but its gilded ornaments rendered it very unfightly. There is alfo here a fmall altar piece, faid to have been painted by Dyer the poet. The fubject is the laft fupper, but it is in part a copy from Pouffin, and is bad."

A glen about a mile from the town, on the right of the road leading to Builth, was pointed out to me as containing a cataract, and fome beautiful fcenery. I was, however, greatly difappointed in finding thefe fcarcely worth notice. The face of the rock had much the appearance of a hattered wall, thrown aflaunt by one end finking into the ground. The water fcarcely trickled down it, and if I might judge from the muddy pool at the foot, it very feldom defcended in quantity fufficient to entitle the ficene to the appellation of a cataract.

Returning to Newtown, I croffed the river, and walked along its banks about three miles and a half to

\section{Castell Dolforiwyn,}

The Caftle of the Virgin's Meadow. The remains of this fortrefs are to be found on a lofty hill, on the north-weft bank of the Severn, a fituation that commands the whole of the adjacent country. From hence I had a lovely and extenfive profpect of the vale 
vale of Severn, through which the river was feen to glide in elegant curves, blackened by its high and fhady banks. The landfape was enlivened by the luxuriance of woods and meadows; and the towns and villages around lent their aid to decorate the fcene.

The caftle has been a four-fided building, of no great ftrength, about fifty yards long, and twentyfive wide; and the exterior walls appear to have been about four feet in thicknefs. A fmall part of the north wall, with fome trifling remains of the interior of the building, are yet left. The fouth and the eaft walls are entirely demolifhed, and the other parts that are yet ftanding are greatly thattered.

There have been various conjectures refpecting the founder of this caftle. Dugdale attributes it to David ap Llewelyn, prince of North Wales, about the middle of the thirteenth century *. Stowe fays it was the work of Llewelynt; and Mr. Evans, who is now generally thought to be right, that it was indebted for its origin to Bleddyn ap Cynvyn, fome time betwixt the years 1066 and $1073 t$.

In the fixth year of the reign of Edward I., Bogo de Knovill was made governor; and, in the follow. ing year, the caltle was granted to Roger Mortimer,

* Dugda'e's Monaticon, ii. 223.

+ Annals, 200 .

F Evans's Differtatio de Bardis, 92. from the Inftitutiones Lingux Cymraccx, of John Darid Rhys. 
earl of March, to hold to himfelf and his heirs on the fervice of a knight's fee*. His fon was attainted of high treafon, but afterwards, on the reverfal of the attainder, it was reftored to the family in the perfon of his grandfon. By the marriage of Anne, the fifter to the laft earl of March, with Richard Plantagenet, earl of Cambridge, this, and fome other Welfh caftes, became the property of the houfe of York, and thence defcended to the crown $\uparrow$.

Thefe are all the memoranda of any importance that I have been able to collect refpecting this fortrefs.

How it firft took the name of Dolforwyn, or The Meadow of the Virgin, cannot now be afcertained. Circumftances would, however, induce one to fufpect, that it had fome allufion to the ftory of Habren, or Abren, the daughter of Locrine, fon of Brutus, the firt king of Britain, by Effyllt, a daughter of the king of Germany, whom he had taken captive in his wars againft the Huns. Previoufly to the taking of this female he had efpcufed Gwendolen, a daughter' of Corineus, one of the heroes who had

* Dugdale's Baronage, ii. 5. and i. 142. Stowe's Annals, 200. A knight's fee was defined to be fuch an inhcritance, as would maintain a knight with convenient retinue for a year: in the time of Heury III, this was eftinated at the triling fur of fifteen pounds. By a ftatute paffed in the reign of Ed. ward II., it was raifed to twenty, and afterwards to forty pounds. Sir Edward Coke fays, that a knight's fee contained twelve plowe lands, or !x hundred and eighty acres.

+. Dugdale's Baronage, i. 148 . 
entered the ifland along with Brutus from Troy. The chieftain fearing that Locrine's reported attachment to Effyllt might break off the intended marriage with his daughter, threatened with his army to compel the fulfilment of his promife. Locrine, thus circumiftanced, was under the neceflity of concealing Effyllt in a cavern, declaring that the had left the kingdom, and, greatly againft his inclination, was married to Gwendolen. On the death of Corineus, which appears to have taken place but a fhort time after the nuptials, he immediately divorced Gwendolen, and acknowledged Effyllt to be his queen. When he died, Gwendolen affumed the government, and the revenged herfelf for the injuries the had fuftained, by caufing Efryllt and her daughter Abren to be caft into the river. From this circumftance, the old writers fay, the ftream. aflumed the name of Abren; which afterwards, by a flight alteration, became Sabrina, and then Severn*.

Sabrina is lier name, a virgin pure,

Whilome the was the daughter of Locrine,

* This event is faid to have taken place above 1000 y"ears before the birth of Chrit. The moft ancicnt account of it extant is found in Tyfilio's Hifory of Britain from the fettlement of the Trujan colony to the reign of Cadwaladr, the laft king of the Britons. This work is intitled Brut y Brenbinocdl; it was writien about the year 6.0, and is the fame that Geoffry of Mosmouth afterwards publifhed, but with innmerable alterations, in Latm. See alfo Matt. Weftm. p. zo. Speec's Maps, ch. x. fol. 1 1 5., and Whitclock's Niemorials from Brutus, p. 2 . 
That had the fceptre from his father Brute. The guiltlefs damfel flying the mad purfuit Of her enraged itepdame, Givendolen, Commended her fair innocence to the flood, That ftayed her flight with his crofs-flowing courfe, The water nymphs, that in the bottom play'd, Held up their pearled wrifts, and took her in, Bearing lier ftraight to aged Nereus' hall; 'Who, piteous of her woes, rear'd her lank head, And gave her to his daighters to embathe In nectar'd leaves, ftrow'd with afphodel; And through the porch and inlet of each fenfe, Dropt in ambrofial oils, till fine reviv'd And underwent a quick immortal changeMade goddefs of the river: the ftill retains Her maiden gentlenefs, and oft at eve Vifits the herds along the twilight meadows, Helping all urchin blafts, and ill-luck figns That the fhrewd meddling elf delights to make, Which the with precious viol'd liquors heals;

For which the fhepherds at their feftivals

Carol her goodnefs loud in ruftic lay,

And throw fweet garland wreaths into her ftream,

Of panfies, pinks, and gaudy dafodils. And as the old fwain faid, the can unlock The clafping charm, and thaw the numbing fpell, If the be right invoked in warbled fong;

For maidenhood the loves, and will be lwift To aid a virgin, fuch as was lierfelf, In hard befetting need. 


\section{(66)}

\section{H A P. IX.}

\section{Newtown to MONTGOMERY.}

View near Abermule. - Montgomery. - Church. - Hiftory of the Town.-Montgomery Cafle. - Skctch of its Hifory. = Rural Scene.-Leland's Defcriplion of the Town.-The Cucking Stool, formerly in ufe here.-Memoranda of Lord Herbert of Clirbury.

$F_{\text {Rom }}$ Newtown I had a fine cyltivated country all the way to Montgomery. The infant Severn accompanies the road nearly half the way, in fome places approaching, and in others bending from it, and hidden by intervening trees and hedges.

The few houfes at Abermule, The Conflux of the River Mule, about five miles from Newtown, were delightfully fituated on the bank of the Severn, fur. rounded by hills, and decorated by woods, in all the luxuriance of foliage. From hence the road gently afcends, and from the eminence a view fo extenfive and beautiful burfts on the fight, as to defy the utmoft expreffion of the pencil to reprefent it. A vale in high cultivation is feen to extend for feveral miles, the Severn appearing in different parts from among the trees and meadows: The whole fcene was bounded by diftant hills. The defcent continues ftill beautiful; and, near the town of Montgomery, 
the fine ruins of its caftle formed a very interefting addition to the profpect.-The road is fo much elevated immediately above the town, as to afford the traveller a bird's eye view into almoft every ftreet.

\section{Montgomery,}

From the neatnefs of its houfes, feemed to me to be inhabited principaliy by perfons of fmall fortune, who had fettled here to lead a life of retirement. It is clean, and well built; and feems capable of affording the comforts and conveniences, without any of the buftle and noife of a large town. All the adjacent country is decorated with the moft lively and luxuriant fcenery.

The church is an elegant cruciform ftructure, dedicated to St. Nicholas, and contains an ancient monument, to the memory of Richard Herbert, efq. the father of the very celebrated lord Herbert of Chirbury, and his lady. The two figures are recumbent, under what has once been a magnificent and much ornamented canopy. In an adjacent cor. ner of the church, I obferved a large collection of legs, arms, heads, and trunks of other monumental figures, but all of them fo much thattered, that I could make nothing out of them. On the grave. ftones in the church-yard I remarked more epitaphs than I had ufually feen together before. Among fuch a number, many were of courfe ridiculous. 
In the year 1092 , a few of the Norman barons that were fettled in the Marches, were allowed to wreft all the territory they were able from the Welfh, on condition that they fhould hold it as tenants, in capite, under the crown. Roger de Montgomery, earl of Shrewibury, entered Powilland, and took poffeffion of this place, then called Tre-faldwyn, or Baldwyn's Torun, from its having been built, and fortified with a cartle by Baldwyn, lieutenant of the Marches to William the Conqueror. The earl did homage to the king for thefe poffeffions, fortified the place afreh, and called it, after himfelf, Montgomery *

\section{Montgomery Castle.}

The caftle is fituated on an. eminence on the north fide of the town, and appears to have once been a grand and majeftic building. It is, however, at prefent fo much demolifhed, that it is impoffible to trace its extent with any degree of accuracy. It ftood on a rock precipitous on one fide, and fo elevated as to overlook all the immediately adjacent country. The prefent remains confift of a finall part of a tower at the fouth-weet angle, and a few low and fhattered walls. In this tower I obferved feveral fmall holes, fimilar to thofe I have mentioned as found in the walls of the Roman fort at Segontum near Caernarvon; and thefe ferved more clearly

\section{Powell, 152. Matt. Weftm. III. Camden, iii. 53r.}


to convince me that they were all originally formed for no other purpofe than to reft in them horizontal poles, for the fupport of the fcaffolding ufed in the erection. Some of thefe are near fix feet deep. This fortrefs feems to have been defended by four foffes, cut in the rock, each of which had formerly its drawbridge.

\section{History of Montgomery Castie.}

I have already remarked that Tre-faldwyn, or, as it was afterwards called, Montgomery, was built and fortified with a caftle during the reign of William the Conqueror, by Baldwyn, lieutenant of the Marches; and that in i092, the place was fortified afrefh as the property of Roger de Montgomery, earl of Shrewrbury. In the following year, the Welih muftering all their force, rofe in arms, feized and ranfacked the caftle*. William Rufus marched with an army to the relief of the Englifh, retook and repaired the caftle; but, in his encounter with the Welfh, having loft a great number both of men and horfes, he was compelled to return into England to recruit his forcest. Montgomery caftle was at this time believed to be the ftrongeft fortrefs in Wales, and the Welfh, after William's retreat, again commenced an attack upon it. The Norman fol.

* Leland's Collectanea, ii. 314 .

† Powel, 153. Matt. Paris, p. 15. Matt. Weftm. 17. Ho. linhed, ii. 20. 23 . 
diers gallantly defended it for many days, but the Welih, having found means to undermine the walls, took it by ftorm, and afier putting the whole garrifon to the fword, levelled the fortrefs to the ground. 'The Englin ftruggled ineffectually againft this hardy poople for near four years. At length they obtained a decifive victory. The caftc was immediately rebuilt by the earl of Shrevflbury; but in little more than a century afterwards was again deftroyed.

It appears that in $122 \mathrm{I}$, Henry III., in order to reftrain the predatory excurfions of the Welfh, erected a caftle at Montgomery, which he granted to his jufticiary, Hutert de Burgh*.-About feven years fubfequent to this period, as fome of the garrifon's foldiers were attempting, with the affiftance of the country people, to open a road through an adjoining foreft, which had long afiorded to the Welfh a fecure afylum; from whence iffuing, they frequently murdered and plundered travellers through the country; they were on a fudden attacked by a body of the natives, who with great flaughter compelled them to feek refuge in the caftle. The party then inverted, and laid regular fiege to it, on which Hubert de Burgh, alarmed at his fituation, fent to Henry for fuccour, who brought an army to his aid, on the arrival of which the Welfh immediately fledt.

* Matt. Paris, 263. Matt. Weftm, p. I1 . Holinhed, ii. 203. Carte, i. 466.

f Powel, 284,285. Matt. Paris, 295. Carte, ii. 357 . 
In the year 123I, a party of Welihmen having made an excurfion into the lands adjoining the caftle, they ware intercepted by the Englin, and many were taken prifoners, and beheaded. Prince Llewelyn ap Iorwerth, in retaliation for this injury, affembling an enormous force, laid wafte all the Englifh borders. During the general confternation, Hubert de Burgh evacuated the caftle; it was immediately feized by the Wellh, who fet fire to and deftroyed it, and hortly afterwards attacked and demolifhed fome of the caftles in South Wales*.

In a conference held at Montgomery, in the year I 268, a peace was eftablifhed betwixt Llewelyn ap Griffith, then prince of North Wales, and king Henry III. That prince paid down a fine of 32,000 marks, and in return received four cantreds, or hundreds, in Wales, which during the wars he had loft + .

From an inquifition taken on the reverfal of the attainder of Roger Mortimer, earl of March, in the year 1345, it appears that he had been poffeffed of Montgomery caftle at the time of his death. It was in confequence reftored to the family, and paffed, with his other caftles and property, by the marriage of Anne, the fifter of the laft earl, into the houfe of York, and thence to the crown $\neq$.

- Powel, 287. Matt. Paris, 311.

† Matthew Paris fays, "Triginta duo millia librarum fterlin. gorum regi conceffit." p. 857. Matt. Weft. 347.

$\ddagger$ Dugdale's Baronage, i. $147 .-150$. 
This fortrefs was held by the immediate anceftors of lord Herbert of Chirbury, as ftewards for the crown, and it was their principal place of refidence*.

In the civil war's of the reign of Charles I., lord Herbert was made governor. On the arrival of the army of the parliament in 1644 , under the command of fir Thomas Middleton, he declared himfelf of that party, and on treaty permitted the men to enter the caftle. Not long after this tranfaction, lord Byron advanced with the king's forces, confifting of about four thoufand men, on which IVIiddleton was compelled to flee to Ofweftry, leaving his footfoldiers with lord Herbert to defend the caftle. The royalifts commenced their attack; but fir Thomas having been joined by fir John Meldrum, frr William Brereton, and fir William Fairfax, returned with about three thoufand men to the relief of the place. Lord Byron brought forward his men to engage them, but, after a dreadful conflict, which lafted more than eight hours, the parliament's army obtained a complete victory. The routed troops fled towards Shrewfbury, and the purfuit was continued near twenty miles. In this battle betwixt three or four hundred of the king's party were flain, and above a thoufand taken prifoners. Sir William Fairfax, major Fitzfimons, and about fixty men belonging to the parliament, were killed, and about a hundred

* Life of lord Herbert, 5 .

others 
others dreadfully wounded *.-The caftle met the fate of all others, in being difmantled by order of the Commons. Lord Herbert, however, received from the parliament a fatisfaction for the lofs of his property $t$.

\section{Rural Scene.}

It was on a fine, ferene morning in the beginning of September, that I happened to be at Montgomery; and I was fo much delighted with the extenfive and varied profpect from the caftle, that I refted under the cool thade of one of its walls for near an hour, feafting my eyes with the lovely picture before me. The fcene, which was calculated for almoft Arcadian felicity, was enlivened by the bufy work of harveft, and the merry carol of the reapers floated cheeringly through the air. The ruftic fwains and damfels were all affiduoufly employed in gathering the yellow riches of the fummer. Some were cutting, others binding; and the gleaner,

With bended thoulders traverfing the field,

Followed the loaded waggons, ftoring up with care every ear that fell.-I love to contemplate thefe ruftic fights.

Hail, therefore, patronefs of health and eafe,

And contemplation, heart-confoling joys,

* Rufhworth, ii. part 3. p. 746, 747. Whitelock, 104.

$t$ Life of lord Herbert. 
And harmisfs pleafures in the throng'd

Abode of multitudes unknown! Hail, rural life!

Addrefs himfelf who will to the purfuit

Of honours, or emuluments, or fame;

I frall not add myfelf to fuch a hare,

Thwart his attempts, or envy his fuccefs.

\section{The Town of Montgomery}

Was formerly defended by a circumambient wall, ftrenghtened with towers. Leland, in the fixteently century, thus defcribes it : "The foyle of the ground of the towne is on mayne flaty rocke, and eipecially the parte of the towne hillinge toward the caftell, now a late re-edified, whereby hathe been a parke. Great ruines of the waulle yet apere, and the remains of foure gates, thus called, Kedewen Gate, Chirbury Gate, Arthur's Gate, and Kerry Gate. In the waulle yet remayne broken tourets, of the which the white tower is the molt notable*."

King Henry III. granted to Montgomery the privileges of a free borough.-The town is now governed by two bailiffs, and twelve burgefles, or common-council men; and it fends one member to parliament, who is elected by the burgeffes, and re. turned by the bailiffs $t$.

\section{CuCKING-STOOL.}

In Blount's Ancient Tenures and Jocular Cuftoms, I find that this fingular inftrument of juftice

* Leland's ltin. vii. $16 . \quad+$ Camden, ii. 780. 
was once in ufe at Montgomery. Whenever any woman was found guilty, in the judgment of the free burgeffes of the town, of caufing ftrifes, fightings, defamations, or other difturbances of the public peace, the was adjuiged to the goging-ftool, or cucking-itool, there to ftand, with her feet naked, and her hair difhevelled, for fuch a length of time as the burgeffes fhould think proper, as a public warning to all who beheld her. This is the fame kind of inftrument which was ufed among the Saxons. It was called by them fcealfing, or fcolding ftool, that is, a chair in which they placed fcolding women as public examples; but, in addition to this, if the enormity of the cafe required it, this people alfo plunged them over the head in water. The engine in general confifted of a long beam, or rafter, that moved on a fulcrum, and extended towards the centre of a pond: at its end was fixed the ftool, or chair, on which the offender was made to fit. It was called by the Wellh Y Gadair Goch, The Red Cbair*.

* Jacob fays of the cucking-(tool, (tumbrellum,) that it was "6 an engine invented for the punifhment of fcolds and unquiet women, by ducking them in water, called in ancient time a Tumbrel, and fometimes a Trebucket. In Domefday it is called Cathedra Stercoris ; and the Saxons defcribed it to be Catbedra in qua rixofa mulieres fedentes, aquis demergebantur. It was anciently a punifhment inflicted upon brewers and bakers tranfgreffing the laws, who were thereupon in fuch a ftool immerged over head and ears in (ftercore) ftinking: water. Some think it a corruption from ducking-ftool, and others from choaking-ftool, quia boc modo demerfa aquis ferè fuffocantur." Sce Jacob's Law Dictionary. 
Ye vixen dames, your neighbour's pen, Unlefs your tongues in future reft, Know that with all your faults, your fate Is the red.ebnir's degrading feat *.

Migarinda of Lord Herber't of Chrrburg.

'This very fingular and celebrated charater, whof: property and refidence in Montgomery caftle call for a mention of him in this place, was borr in $15^{8} 3$.-During feveral of the firft years of his life he was very puny and fickly; and he did not acquire the ufe of fpeech for fo long a time, that moft people fuppofed, if he did furvive, that he would be entirely dumb. In his life, written by himfelf, he fays he could remember that he underftood what was faid by others, but that he forbore to fpeak, left be flould utter fometbing improper! One of his firlt queltions was, he fays, bow be came into the world?

At feven years old it was thought proper that he thould be taught to read, and he made fo great a proficiency, that in the courfe of five years he had attained a competent knowledge of the Latin and Greek languages, and of logic. He was, at this early age, admitted a ftudent in Univerfity College, Oxford. Here he obtained uncommon applaufe by his logical difputations, and from compofing his exercifes more frequently in Greek than in Latin.

* Welf epigram of William Phylip, tranßated by Mr. Lloyd, the author of Beaumaris Bay. 
Sir William Herbert of St. Julian's had an only Jaughter, to whom, on his death, he bequeathed all his poffeflions, on condition only, that the fhould marry fome perfon of the name of Herbert. She continued unmarried till the was of age, when young Herbert, then only fifteen years old, was propofed to her. She accepted the youth for her hurband, and they were united in February $\mathbf{i} 598$.

He returned to Oxford with his wife and mother, took a houfe there, and continued his itudies mith affiluity. Befides clafical literature, he attained a knowledge of the French, Italian, and Spanifh-languages, and this without any affiftance. He alfo acquired fome knowledge of mufic and medicine; and in the latter he pretended to cure many diforders that baffled the fkill of the mort able phym ficians: in the account of his life he enumerates feveral cafes.

Three years after his marriage he quitted Oxford, and refided in London till he was twenty-one.Soon after the acceffion of James I. he was created a knight of the bath; and he declares that he adhered ftrictly to the tenor of his oath of knighthood, which required him never to fit in the place where injuftice fhould be done, but to right it to the utmoft of his power; and in cafe of ladies or gentlemen being wronged in their honour, if they demanded his affiftance, that he fhould give it without referve, \&c.-In this character it is that, " in one point of view we obferve him, like the knight of 
La Mancha, fighting with windmills, redreffing the wrongs of diftreffed damfels, and rifking his life, to wreft the top-knot of a girl but ten years of age, from the hands of a rude defpoiler; whilft at other times we difcern the fame man devoted to a life of retirement, and with equal fpirit cultivating philofopliy, hiftory, and poetry:."-In the true fpirit of knight errantry, he once perfonally challenged a celebrated French cavalier, in the following form: "I hear that you have a fair miftrefs; I will main. tain that I have one more worthy, and will do as much for her fake as you will dare for yours." The challenge was, however, too ridiculous to be accepted.

In the year 1608 he vifited France, Germany, Switzerland, and Italy, and performed in thefe countries many acts of extraordinary heroifm. Soon after his return he was appointed ambaffador to France; and, in 1621 , James I. advanced him to the dignity of a baron of the kingdom of Ireland. Ten years fubfequent to this he was created an Englifh peer, by the title of lord Herbert of Chirbury in Shropfhire.

In the rebellious troubles of the reign of Charles I. he for fome time efpoufed the royal caufe, and defended his prince on every occafion with a manly fpirit, but afterwards, from the weaknefs and divifion of the king's councils, he went over to the popular fide, and took part with the parliament.

* Coxe's Hiftorical Tour in Monmouthnire, Iog. 
He died in 1648 , at the age of fixty-feven, and was interred in the chancel of the church of Sto Giles in the Fields *.

In confidering the character of lord Herbert, it is evident that vanity was his prevailing foible. Hence he reprefents himfelf, from his infancy, as the moft extraordinary of all human beings. Common incidents he exaggerates into unprecedented events. Hence he informs us, as miraculous circumftances, that he grew the breadth of two little fingers after he was thirty years old; that he weighed lighter. than other men who were both lower in ftature, and more flender than himfelf; that he had a conftant pulie in the crown of his head; and that his thirt and under garments alwrays finelt uncommonly fweet.-As a foldier he won the efteem of the brave: as a knight his chivalry was drawn from the fair queen. Had he been ambitious, the elegance of his figure and perfon would have carried him to the highelt pitch of honour. He obtained particular notice from queen Elizabeth and Anne of Aufria; and he received fuch marked attentions from Anne of Denmark, the queen of James I., as to attra\& public notice, and excite the jealoufy of his fovereign.

* The following infeription, his own compofition, is to be feen on a flat marble flab over his grave. "Hic inhumatur corpus Edvardi Herbert, equitis balnei, baronis de Chirbury et Caftle inand, auctoris libri, cui titulus eft, $D e$ Veritate. Reddor ut herbx, vicefmo die Augufti, anno Domini, I648." 
Lord Herber was alfo remarkable for agility in all bodily exercifes; in running, leaping, wreftling, and fencing, he had few equals; and he was uncommonly expert in the management of his horfe, and in fighting duels on horfeback. 'He records the following inftance of having faved his life when the advantage was greatly againft him.--Sir John Ayres, imagining that lord Herbert had improper connexions with his wife, made feveral attempts to affaffinate him. He was paffing Whitehall on horfeback, with only two fervants, when fir John, and four men, fet upon him at once. In an early part of the encounter his fword was broken within a foot of the hilt, and his horfe was fo much wounded, that he attempted to alight. At that moment fir John rufhed up, and from the horfe ftarting againft him, lord Herbert was thrown off: one of his feet hung in the firrup, and in this fituation, with only a broken fword in his hand, he had to defend himfelf. Sir John Ayres made feveral attempts to ftab him, all of which he parried with the utmoft dexterity, and, feizing a favourable moment, caught the knight by the legs, and brought him to the ground. One of his fervants now freed his foot from the ftirrup, he got up, and with the poor remains of his weapon, put himfelf into a pofture of defence. He allowed fir John to rife, and two friends taking part with his two fervants againft his adverfary's four adherents, he at length with his broken fword completely difa armed the knight, and beat of the other affailants. 
In his own age lord Herbert was alfo juftly efteemed a prodigy of learning, but in his literary purfuits we obferve the fame enthufiafm, affectation, and eccentricity, as were apparent in all his other actions. He was the author of feveral works: A life of Henry VIIÍ.; Memoirs of his own Life; a treatife "De Religione Gentilium, Errorumque apud eos Caufis;" and a work which he efteemed fo excellent, as even to infert its title in his epitaph, "De Veritate."

This nobleman is faid to have been the firft author who formed Deifm into a fyftem, and endeavoured to affert the fufficiency, univerfality, and abfolute perfection of natural religion, without the neceffity of any extraordinary revelation. He attempted to prove that the light of reafon, and the innate principles implanted in the human mind, were fufficient to difcover the great doctrines of morality, to regulate our actions, and conduct us to happinefs in a future ftate. But at one moment he enforces the belief of a Deity in terms of the higheft veneration, and inculcates the neceffity of a future ftate, and the doctrine of rewards and punifhments, and at another labours to undermine the truth of the only religion which afcertains the exiftence and attributes of a fuperintending Deity, and fubftantiates by moral and hiftorical proof the certainty of future retribution.-All his pofitions have been ably refuted by Locke, I.eland, and others. 
But at the fame time that he combated enthufrafin in his writings, his actions proved that he was himfelf an enthufiaf...t hen his treatife "De Veritate" was finifled, he long doubted whether it ought to be given to the world, as, though he ftill confiders revelation of no utility, yet this differed from all his other writings concerning the difcovery of truth.

"Being (fays he) thus doubtful in my chamber, one fair day in the fummer, my cafement being opened towards the fouth, the fun fhining clear, and no wind ftirring, I took my books De Veritate in my hand, and kneeling on my knees devoutly, faid thefe words; "O thau eternal God, author of the light which now thines upon me, and giver of all inward illuminations, I do befeech thee of thy infinite goodnefs to pardon a greater requeft than a finner ought to make; I am not fatisfied enough whether I Thall publin this book De Yeritate: if it be for thy glory, I befeech thec give me fome fign from Heaven, if not, I thall fupprefs it.' I had no fooner fpoken thefe words, than a loud, yet gentle noife, came from the heavens (for it was like nothing on earth), which did fo comfort and cheer me, that I took my petition as granted, and that I had the fign I demanded. Whereupon alfo I refolved to print my book. This, (how ftringe foever it may feem,) I proteft, before the eternal God, is true; neither am I any way fuperftitiounly deceived herein, fince I did not only clearly hear the noife, but, in the 
fereneft day I ever faw, being without all cloud, did to my thinking fee the place from whence it came. And now I fent my book to be printed at Paris at my own colt and charges*."

This blind and foolifh conduct is warmly reproved by the late earl of Orford in his Royal and Noble Authors. "There is no ftronger characteriftic of human nature, than its being open to the grofleft contradictions: one of lord Herbert's chief arguments againft revealed religion is the improbability that Heaven hould reveal its will to only a portion of the earth, which he terms particular religion. How could a man who doubted of partial, believe individual revelation? What vanity, to think his book of fuch importance to the caufe of truth, that it could extort a declaration of the divine will, which the interefts of half mankind could not!"

The fum of the character of lord Herbert has been thus drawn in few words. "He ftands in the firt rank of the public minifters, hiftorians, and philorophers of his age. It is hard to fay whether his perfon, his underftanding, or his courage, was the moft extraordinary, as the fair, the learned, and the brave, held him in equal admiration. But the fame man was wife and capricious; redreffed wrongs, and quarrelled for punftilio; lated bigotry in religion, and was himfelf a bigot in philofophy. He expofed himfelf to fuch dangers as other men of

* Life of lord Herbert, p. I72. 
courage would have carefully declined; and called in queftion the fundamentals of a religion which none had the hardinefs to difpute but himfelf *."

* This account of the life and character of lord Herbert is compiled principally from his Life publithed by himfelf; Coxe's Hiftorical Tour in Monmouthhire; Pennant's Tour in Wales; Walpole's Royal and Noble Author's; and Granger's Biogra. phical Dictionary. 


\section{HAP. X.}

Montgomery to Welsh Poot.

Wels Pool. - Church.-Powis Cafle.-Hiflory of Powis Caflh, and Account of Porvifland.

LeAving Montgomery, I went over a rich champaign country, about ten miles, to Wellh Pool. I paffed on the left Powis caftle, fituated on the narrow ridge of a rock, about a mile from Pool. For three or four miles of the road this building is a friking object in the fcene.

\section{Welsh Pool}

Is a large and populous place, and from its vicinity to England, it has affumed much the appearance of an Englifh town. The houfes are in general well built, and principally of brick. There is one long and handfome ftreet, in which ftands the county hall, an elegant ftructure, erected by fubfcription a few years ago. The manners of the inhabitants of this town are fo completely Englifh, that even the language of the country feems fcarcely known here. An air of opulence unufual in Wales may be ob. ferved throughout the place, owing to the trade

$$
\text { G } \hat{3}
$$


in Welfh manufactures, which is carried on to a great extent. It is principally reforted to as a market for W. Ih flannels, which are manufactured here, and in various adjacent parts of the country: from hence thefe are fent into England, and prin. cipally to Shrewibury and Liverpool - The Severn is navigable to a place called Pool Stake, within a mile of Welfh Pool, although upwards of two hundred miles from its mouth in the Briftol chan. nel.

The cburch, apparently a modern fructure, is fingularly fituated at the bottom of a hill, and fo low, that the upper part of the church-yard is nearly on a level with its roof. This church has a chalice which was prefented to it by Thomas Davies, fome time governor-general of the Englifh colonies on the weftern coaft of Africa. It is formed of pure gold brought from Guinea, and is valued at about a hundred and feventy pounds. Notwithftanding the evidence of its infcription to the contrary, the fexton informed me, with much affurance, that this chalice had been given to the church by a tranfported felon, who, from induftry and application during his banifhment, had returned to his country the poffeffor of confiderable wealth.-I was fomewhat furprized in obferving in the choir a few branches of ivy that had penetrated the roof, and were permitted to hang entwined round each other in a cylindrical form, to a length of more than eighteen feet. The neatnefs of the place was not in the leaft injured by them, 
them, and I prefume their fingularity was the caufe of their prefervation.

\section{Powis Castue}

Has been originally built of a reddilh ftone, but in order to keep the ftructure in repair, this has of late years been fo plaiftered over with a coat of red lime, that at prefent very little of the ftone is vifible. This red coating gives to the building fo much the appearance of brick, that it was not till I almoft touched it, that I was undeceived in fuppofing it fuch. The antique grandeur of this cafte is much injured by the great number of chimnies, and by the ftriking and harm contraft betwixt the walls and the modern fafin windows.

The afcent to the caftle is up a long and laborious flight of fteps, much out of repair when I was there; and the principal entrance is a gateway betwixt two large round towers. The edifice is kept in repair as an habitable manfion, but its owner very rarely vifits it. The apartments have a heavy and unpleafant appearance, from the great thicknefs of the walls; and the furniture is chiefly in the ancient ftile of elegance. In fome of the chambers the old and faded tapeftry is yet l.f. The e are, wifferent rooms, feveral portraits, chiefly of the fainily, the beft of which are the work of Cornelius Janfon. Among them there is one of king Charles II. painted by fir Peter Lely, two of the earl of Strafiord, one

$$
\text { c } 4
$$


of lord Herbert of Chirbury, and others of various other celebrated characters. In the gallery, which is near a hundred and twenty feet in length, there is a fmall collection of antiques, fome of which are fuppofed to be valuable.

The gardens were laid out in the wretched French tafte, but in 1798 , when I faw them, they were greatly out of repair.

The profpects from the terrace are very extenfive, this fituation commanding all the beautiful and fpacious country eaftward, interfected by the Severn, and the Breiddin hills; with much of the cultivated and well wooded county of Salop.

\section{History of Powis Castle.}

Leland informs us that there were formerly at this place two caftles included in the fame walls. "Welfch Pole had (he fays) two lord's marcher's caftles within one waulle, the lord Powys, named Greye, and the lord Dudley, caullid Sutton; but now the lord Powys hath bothe in his hand. The Welich Pole caftle is in compas almoft as much as a little towne. The lord Dudlcy's part is almoft fallen downe : the lord Powys part is meatly good*."

Whether thefe caftles were erected at the fame, or at different times, I have not been able to learn, nor what were their diftinct names. None of the writers, except Leland and Camden, mention more

* Leland's Itinerary. 
than one caftle. This was anciently called Pool Caffle, from its vicinity to Pool ; and Caftell Coch, the Red Caftle, from the hue of its ftone. Its name of Powis Caftle, which is more modern, it feems to have obtained from its having been the principal place in that divifion of Wales called Powifland.

The principality of Wales was anciently divided into North Wales, South Wales, and Posvifand. This was a tract of land which once extended, in a Atraight line, from the Broxton hills in Chefhire, fouthwards to Shrewfbury; from thence through the eaftern limits of Montgomeryfhire, including all that county, part of Radnorihire, and Brecknockfhire; then turning northward, it comprehended. part of Merionethire, the whole of Denbighnire, except the lordihips of Denbigh and Ruthin; and from thence it went towards the fouth-eaft, and included Molefdale, Hopedale, and Maelor, in Flintthire *.

This particular part of Powifland was obtained from the Wellh by Henry I., who, about the year 1110, gave it to Cadwgan ap Bleddyn ap Cynvyn, a Wellhman, who had rendered himfelf eminen by his fervices and bravery. He began to erect a caftle here with an intention of making this the place of his refidence, but before the work was finifhed, he was murdered by one of his relationst. The caftle

$$
\text { * Pennant, i. zrz. + Powel, } 170 .
$$


appears to have been completed before the end of the fame century; for in 1191 , on various depredations having been committed by the Wellh in the marches, Hubert, archbihop of Canterbury, in the abfence of Richard I., on the crufades, haftened here, and with a powerful army befieged the caftle, at that time in the hands of the Welih. The garrifon did not, however, furrender till they perceived that the befiegers had undermined their walls; and they did this at laft on honourable terms, notwithftanding the Englih forces being at leaft thrice their own number. As foon as the archbifhop had obtained poffeffion he fortified it afiefh, and he left it, with a very ftrong garrifon. The Welh, how. ever, foon again attacked and re:ook it*.

It changed owners again not long afterwards, for in 1233 it was attacked and feized by prince Llew. elyn ap Iorwerth $\dagger$.

It defcended to Ilewelyn's grandfon, Owen ap Griffith, and on his death to his daughter Hawys Gadarn. Four of her uncles difputed her title to the property, under the allegation that a female was incapable of inheriting. Kning Edward II., however, took her part; the was married to John de Charlton, and the eftates continued in their pofterity for feveral generations.-The barony and title went afterwards to fir John Grey of Meton in Northumber.

- Powel, 243. Movedon, 775. Stowe, 163. The two latter -reriter 3 fay that this erens look place in 1.97.

$+P u w c l, 288$. 
land, by marriage with Joan the daughter of Edward lord Powys : thefe remained in their defcendants till the reign of Henry VIII., when the title became extinct. - The eftate went, by purchafe, to fir Ed. ward Herbert, the fecond fon of William earl of Pembroke, who died in the year I 594*.

In Oetober 1644 , Powis caftle was attacked and taken for the parliament by fir Thomas Middleton, Its owner, Percy lord Powys, was taken prifoner, all his eftates were fequeftered, and he was obliged to compound for them. During the fiege the caftle is faid to have received much damage in its outer walls from the enemy's cannon $t$.

- Pennant, ii. 378. Yorke, 88.

† Whitelock, 106, 


\section{H A P. X.I.}

\section{Welsh Pool to Oswestry,}

The Ëreiddin Hills. - Llan:mynech. - Llanymynech Hill, and Cavern salled Ogo.-Lime 2uarries.-Projpect from the Hill.-Account of Offa's Dyke. - Ofweflry. - Houfe of Induftry. - Account of the Death of Ofwald. - Monafery. - Churchyard's Encomium on Ofweftry, and the Welf People.-Ofaueftry Cafle.-Account of warious Diflurbances in the Marches of Wales. - Siege of Ofweftry Cafle, and daring Attempt of a $Y_{\text {outh, }}$ which fucceeded in forcing open the Gates.-Charters and Trade. - Sketch of the Hiflory of the Welph Marches.

A воuт fix miles from Welh Pool I pafied a groupe of three lofty mountains called the

\section{BREIDdiN Hills.}

The higheft and moft conical of thefe has the name of Moel $y$ Golfa; the fecond Craig Breiddin; and the third Cefyn y Caftell. On one of them an obelifk was erected a few years ago, from a fub. fcription of feveral of the neighbouring families, in commemoration of lord Rodney's defeat of the French fleet, under the command of the Count de Graffe. 
Juft before I arrived at Llanymynech, I had to crofs the furious little river Virnwy by a ferry.

\section{LLANYMYNECH,}

The Village of the Miners, is a fmall white-wathed village, ftanding on the northern bank of the Virnwy. Its name was evidently derived from the mines in which the neighbourhood formerly abounded, and which were worked in the adjoining hill, called Llanymynech Hill, even fo early as the time of the Romans. Of this there are undeniable proofs. One veftige of their work is a large artificial cave, of immenfe length, called Ogo, from whence they obtained confiderable quantities of copper.-The windings of this cavern are very numerous and intricate. Some years ago, two men of the parifh, endeavouring to explore it, were fo bewildered in its mazes, that, when they were difcovered by fome miners who were fent in fearch of them, they had thrown them. felves on the ground, in defpair of ever again feeing the light.-Previoufly to this period, fome miners who were fearching for copper, found in the receffes of the cavern feveral fkeletons; and near them fome culinary utenfils, a fire-place, and a fmall hatchet. Thefe too plainly indicated that the unfortunate wretches had for fome time dragged on a life of mifery in this gloomy manfion. One of the kele. tons had a battle-axe by his fide, and round his left wrift there was a bracelet of glafs beads, like thofe 
thofe druidical rings called Gleiniau Nadroedd, Snake's Beads*. About fifteen years after this firft difcovery, other miners found human bones, and in one inftance a bone of the arm clafped by a golden bracelet. Several Roman coins of Antoninus, Fauftina, and others, have alfo been difcovered in this cavern.

The hill, befides copper, affords zinc, lead, calamine, and fo much lime, as to fupply the whole county of Montgomery, and great part of Shropthire. In the fummer of 1795 , upwards of eight

* Thefe were glafs rings, ufually about half as wide as our finger rings, and generally of a greenith colour. They were invented and ufed by the druids as amulets, or charms. The popular opinion refpecting them in Cornwall and fome parts of Wales is, that they are not glafs. They are believed to be produced at a certain time of the year by a number of fnakes joining their heads together and hiffing : the people fay that a kind of bubble of a llimy fubstance is formed upon the head of one of them, which the reft, by continued hiffing, blow on till it paffes quite over the bodly and off at the sail, when it immediately hardens. -Another opinion prevalent in Wales is, that at that time of the year when the fnakes ufually caft their fkins, a number of them collect together, and fo entwine themfelves round one, that from the rapidity of their motions, they heat and foften its fcaleo and $\mathrm{kin}$, which being thruft from its liead off at the tail, foon after hardens into a folid ring. When this office has been performed to one, another undergoes the fame, till they have all gone through the operation. Some of the inhabitants affert that they have feen them at work: they fay that at thofe times their eyes appear fiery, and gliten in an extraordinary manner; and that they are fo fierce as immediately to fpring at any one who is unlucky enough to difurb them. 
thoufand tons were exported from hence to different parts of the adjacent country. About a hundred and fifty men are ufually employed here during the fummer in burning the lime, and about fifty in winter in breaking and raifing the ftone.-The lead and zinc obtained here, have of late years been conveyed by the Stourport canal to Birmingham, Macclesfield, and other places*.

From the fummit of Llanymynech hill $I$ had an extenfive view over the plains towards Shrewfbury on the eaft; and, cn the other fide, of the rough and uncultivated parts of Montgomeryfhire, in which I either could, or fancied I could, difcern the lofty cataract called Piftyll Rhaiadr, lighted by the beams of the morning fun, and glittering like a ftream of light down the black front of its rock. Below me was the Virnwy, fweeping in elegant curves along the meadows; and towards the fouth of the Breiddin hills, I had a view in Montgomeryfhire of a feries of wooded and pleafant vales.

\section{Offa's Dyke.}

Under the weft fide of this hill runs the rampart conftruited by Offa, king of Mercia, for the purpofe of dividing his country from Wales, called Clawdd Offa, Offa's Dyke. 'This commences from the river Wye, near Briftol, and extends along Herefordhire, Radnorihire, part of Shrophire and Denbighfhire,

* Cam. Reg. i. 271,272 . 
and ends near Treyddin chapel in Flinthire. From the time of its formation, till nearly the conquen, Offa's dyke was confidered as the dividing line betwixt England and Wales: in 1064 a law was made by Harold, directing that if any Welfhman, coming into England without licence, was taken on the Englifh fide of Offa's dyke, he fhould be punifhed with the lofs of his right hand *. It has been conjectured by fome of our hiftorians that this rampart was intended to protect the kingdom of Mercia from the inroads of the Welfh. "But," fays Mr. Lewis Morris, "how came the king of Mercia to build this wall acrofs the ifland? There muft have been other kings to join him; and it feems the Welfh were plaguy troublefome when there mult have been a wall to feparate them. But I cannot be of the common opinion, that this was a defence againft the Welih, for how foon would they have demolifhed a mud wall if they were fuch terrible creatures? If they were a parcel of poltroons, as fome modern wits will infer from this filly fortification, what occafion was there for any wall againft fuch worthlefs animals? Doth it not feem more likely, that upon a peace betwixt the Englifh and Britifh princes, this was an everlafting boundary line between the two nations, and that they all concurred in forming it $\dagger$ ?"

* Speed's Chronicle. Gibfon's Camden, 585.

t Letter of Mr. Lewis Morris to Dr. Robert Vaughan of Nannau, near Dolgelle. Cam. Keg. ii. 498.

Oswes* 


\section{Oswestry}

Is a confiderable market town in Shropfhire, and a place that during the Saxon times was much celebrated. $-A$ little diftance from the town I paffed a large and elegant brick building, a boufe of induftry, erected a few years ago by the joint fubfcription of feveral of the adjacent parifhes, for the ufe of their poor. From every prefent profpect, this place promifes to afford greater comforts to the poor, and in time to be much lefs expenfive to their maintainers, than if they were fupported in their refpective parifhes.

This town was ancient'.y called Ofwaldftre, a name that it is faid to have obtained from the following event: In the year 642 , the contending armies of Ofwald king of Northumberland, and Penda, the ferocious king of Mercia, met here: the former was routed, and Ofwald fell on the field of battle. Penda, with unexampled barbarity, caufed the breathlefs body of Ofwald to be cut in pieces, and ftuck on poles, as fo many trophies of his victory. Thus the place was called Ofwald's Tree, and forne time afterwards Ofweitry*,-In a manufcript account of the town written in $16_{35}$, I find the following note: "There was an old oake lately ftanding in Merburie, within

* Ofwalchlre, às a Welth word, fignifies only Ofwald's tozun. Previous to the death of Ofwald, this place was called Maefirfelth, or Maeferfield, in the kingdom of Mercia.

rOL. II. 
the parifh of Ofweftry, whereon one of king Ofwald's armes hung, fay the neighbours by tradition *."

Ofwald had beels a great benefactor to various monafteries, and his character was fo much revered by the monks, that a fhort time after his death he was canonized; and the field in which he was flain. became celebrated for the numerous miracles that were believed to have been wrought in it.

On the place of martyriom, as the monks have termed it, a monafery was founded, dedicated to St. Ofwald; but there are no evidences at prefent extant of the tine either of its foundation or diffolu. tion. In the reign: of Henry VHI, no part of the building was left, for Leland, who then vifited this place, fays that the cloifter only was ftanding withir the nemory of perfons then living $t^{\text {. }}$

This accurate writer likewife informs us, that when he was here, the houfes of the town were principally formed of timber, and flated.-On the fouth-weft fide of the church there was, he fays, a

* Harician MSS. in the Dritifh Mufearn, No. $198 \mathrm{r}$.

+ His words are, "The chirch was fomerime a monafterie called the White Minfter. After turnid to a paroche chirch, and. the parfonarge impropriate to the abbey of Strewfoury. 'The cloifter ftood in boninum memoria uli monumsnt monachoram." Itin. $\nabla$ : 39. - This shurch had alfo the names of Blanc Minfter, Candida Ecclefra, and Album Monafterizm, from which circum. flance many writers have fuppofed it tohave been fituated at Whitchurch. This, however, cannot have been the cafe, for Lelaus made his inquiries on the fpot, and it fecms not many ycars after fome parts of it were nanding. s: 
free fchool founded by a lawyer of the name of Holbech, fteward of the town and lordhip.-Not far from the church there was a fine fpring of water, furrounded by a ftone wall, (having a chapel over it,) called Ofwald's Well. Of the origin of this well, the inhabitants had a tradition; that when Ofwald was flain, an eagle tore one of the arms from the body, and making off with it, fell and perihed on this fpot, whence a fpring of water immediately guhed up, which has remained ever fince a memorial of the event.-The town was defended by walls, and was moated round, but in the walls there were no towers except thofe of the four gates.-This place, he fays, was alfo principally fupported by its trade in woullen cloth *.

Of the town of Ofwettry, and of the Welih people, we have a curious encomium by Churchyard:

- Ofweitry's a pretie towne full fine, Which may be lov'd; be likte, and prayfed both.

It ftands fu trim; and is maintaynd fo cleane, And peopled is, with folke that well doe meane: That it deferves to be enrould and fhrynd

In each good breat, and every manly mynd.

3s The market there, fo farre exceedes withall, As no one towne comes neare it in fome fort: For lonke what may be witht or had at call, It is there found, as market men report.

For poultrie, fowle, of every kind fomewhat, No place can thew fo much more cheape than that: All kind of cates that countrie can afford, For money there is bought with one bare word.

* Leland's Itin. v. $37 \cdot 33$. 
"They hacke not long about the thing they fell,

For price is knowne of each thing that is bought:

Poor folke, God wot, in towne no longer dwell, Than money had, perlaps a thing of noughtit.

So trudge they home, buth barelegge and unhod, With fong in Weifh, cr els in prayfing God.

$O$ fweete content, $O$ merrie mind and mood, With fireate of brows, thou lov't to get thy food.

- O plaine gond folke, that have no craftie braines, O confcience cleere, thou knowit no cunning knacks:

O harmlefs hearts, where feare of God remaines,

O fimple foules, as furete as virgin waxe.

$O$ happie heads, and labouring bodics bleft, O fillie doves of holy Abraham's breft:

You neepe in peace, and rife in joye and bliffer for heaven hence, for you prepared is."

\section{Oswestrey Ciastr.e.}

On an artificial mount, at the outfide of the wwn, are the remains of this fortrefs; but they are at prefent little more than a confufed heap of thattered walls and rubbih.

According to the Welf hiftorians, it was founded in 1148 by Madoc ap Meredith ap Bleddyn, prince of Powis, an alky of Henry II.* The Englifh records, however, affign to it a more ancient date... They inform us that it was in being before the Norman conqueft, and that William the Conqueror, fhortly after that event, beftowed it on Alan, one of his Norman friends. The artificial mount on which it was placed, indicates it to have been earlier than

* Powel, zo: 
the Norman æra: The Britons and Saxons gave their fortreffes this fpecies of elevation. The Normans built on the firm and natural foil, or rock; but often made ufe of thefe mounts, which they found to have been the fite of a Saxon caftle. This appears to have been the cafe with that in queftion *.

In the year $12 \times 4$, a complaint was laid to the archbihop of Canterbury by Llewelyn ap Grifith ap Madoc, againft the confable of Ofweftry caftle, for compelling him to put to death two young noblemen, in derogation of their birth and extraction; "which difgrace (he ftates) their parents would not have undergone for three bundred pounds fterlingt!" He alleges alfo, that the conftable had twice imprifoned fixty of his men, when each man was compelled to pay ten fhillings for his liberty; and that when the Welin people came to Ofweftry fair, the conftable would feize their cattle, by driving them into the caitle, and refufe to make any fatisfaction

Two years after this the town was deftroyed by order of king John, on account of Llewelyn, prince of Wales, having refufed to aid him in the contentions with his barons. It experienced a fimilar dif-

* Pennant, i. 264 .

+ This is a fingular valuation of parents of the lives of two cbildren.

$\ddagger$ Phillips': Hitory of Shrewfoury, Appendix, 236. 
after in the reign of Henry III., in being burned during an infurrection of the Welih *.

In the fubfequent reign, that of Edward I., Or. weftry was furrounded with walls, that it might be lefs liable to fuffer froin the plundering excurfions of this people.

Thefe, however, do not appear to have altogether. reftrained them, for during the rebellion of Owen Glyndwr, in the beginning of the fifteenth century, it was again plundered and burnt. $\rightarrow$ Ofweftry has likewife thrice fuffered dreadfully by accidenta! fires in the space of thirty years. In 1542 , two long itreets were thus confumed; two years aftarwards there was a fire more deftructive than this; and in $1_{5}^{67}$ two hundred houfes were burnt to the orround, namely, a hundred and forty within the walls, and fixty in the fuburbs, in only two hours, betwixt twe and four o'clock in the morning $t$.

The contefts, robberies, and difurbanees in the marches of Wales, appear to have been continued with little interruption till a very late period. Both Wellh and Englifh feem to have confidered every thing as lawful plunder which they could feize in each others territory. In confennuence of this, the ftewards, the conftable, and the lieutenant of $\mathrm{O}_{\text {s. }}$. weftry, and Powys, entered into covenants in the year 1534 , to reftrain thefe plundering excur-

- Powel, 287, 288.

t Harleian MSS. in the Britiln Mufeum, No. 198 .

frons. 
flons. It was agreed that if, after a certain day then fixed, any perforn of one lordfhip committed a felony in the other, he thould be taken, and fent into the lordfhip where the offence was coimitted, to receive his punifmment; and that if any goods or cattle were ftolen from one lordhip and conveyed into the other, the tenants, or inlabitants of that lordhip, fhould either pay for the fame within fifteen days, or otherwile four principal men fhould reuain in bail or mainprife till they were either paid for or recovered.-Among the records of the draper's company at Shrewbury, there is the foi! lowing order: " ${ }_{25}$ Elizabeth, ${ }_{5} 5_{3} 3$. Ordered that no draper fet out for Ol ftry on Mondays before $6 \mathrm{o}$ 'clock, on forfeiture of $6 \mathrm{s.} 8 \mathrm{c}$. ; and that they wear their weapons all the way, and go in company? Not to go over the Wellh bridge before the bell toll fix." William Jones, efquire, left to the company one pound fix Thillings and eight-pence, to be paid annually to the vicar of St. Alkmunds's church for rading prayers on Monday mornings before the drapers fict out for OFweftry market.

The town of Ofwetry was rendered by its walls a place, of confilerable ftrength; and during the civil wars of the reign of Charles 1. , it was in poffefion of the royalifts ill June 1644 . It was then befieged by general Mytton and the earl of I enbigh with a force confifing of two troops of horfe, and two hundred foot folders. Thefe were fo furious in their attack, that in the fhort fpace of an hour, and 
with the lofs of only one or two men, a breach in the wall was effected, by which they cntered the town. The inliabitants, in confternation, fled for fhelter to the caftle; but an attack was immediately commenced on it by cannon. A daring youth, of the name of Cranage, was perfuaded by fome of the parliament's officers to faften a petard * to the caftle gate. Being well animated with fack, he undertook the defperate enterprize. With the engine hidden, he crept unperceived from one houfe to another, till he got to that next the caitle, whence he fprang to the gate; he fixed his engine, fet fire to it, and efcaped unhurt. This, by the force of its explofion, burit open the caftle gate, and the place was immediately taken. The deputy governor, four captains, and about three hundred foldiers, were made prifoners. From hence the parliament's fol. diers haftened into Lancafhire to other fervice there.

Previoufly to the attack, the governor pulled down the tower and part of the body of the church, which ftood without the walis, left the enemy hould ufe them to the annoyance of the garrifon $t$.

* A petard is an engine made of copper and brafs, fomer hat in the fhape of a high crowned hat, about ten inclies high, feven in diamerer at the top, and ten at the bottom. Its ufe was to break down gates, barricades, drawbriuges, \&c. which were intended to be furprized. "if fur being loaded with gunpowder, it was faftencd to ine place to be forced, and then lighter by a shatch, which bumt fufficienly long, betore the explofion, to allow the foldier to cicanc.

† Whiteloek, 92. 
About a fortnight after its furrender, the king's forces, confinting of about three thoufand foot, and fifteen hundred horfe, under the command of colone? Marrow, attempted to retake this place. Intimation of their approaeh was inmediately fent to fir Thomas Middleton, who haftening to the affiftance of the garrifon, attacked the king's troops, and completely routed them. After the death of the king the caftle was demolined *.

Ofweftry has at different times been favoured with many privileges from its lords. Iis moft extenfive charter was however granted in the year 1406, by Thomas, earl of Arundel, at that time owner of the place. From this the inhabitants derived feveral advantages which they had not before enjoyed. The chicf of thefe were, that neither the lord nor his heirs fhould feize on or confifcate the effects of any perfon in the corporation that died without making a will; and that none of the inhabitants of the lordhips of Ofwettry, Melverley, Kinardlley, Egerley, Ruyton, and eleven adjacent viliages, at that time called the eleven torens, fhould convey cattle or goods to any other fair or market without having previoufly expored them for fale in the town of Ofweitry, under the penalty of fix hillings and eight-pence for each offence $t$.

- Ruthworth, part iii. vol. 2. p. 744, 745. Whitelock, 94.

+ Pennant, i. 268, 269.

Till 
Till about the end of the fixteenth century there was a very confiderable market at Ofweftry for Wellh flannels: Shrewbury, however, foon after this period, deprived it of the principal part of this trade.

Ofweftry and its hundred, at the making of Domefday, formed a part of Wales. They were taken thence, and annexed to England in the eighth year of the reign of Edward I.

\section{The Welsh Marches.}

As the place I am mentioning was one of the principal towns of the marches, and at different times fuffered very greatly from that circumitance, it is proper that I thould here fay fomething of their nature and government.

It appears from various ancient documents, that after the conqueft of England by the Normans, king William placed feveral of his Norman nobility on the confines of Wales, and gave them power to make fuch conquefts in that country as they were able. By this piece of policy a double end was anfwered: thofe whom he had brought over into England were thus left to provide territory for themfelves; and their power tended in fome degree to reduce the Welth people into fubjection. The lands thus feized we holden, in capitc, of the crown of England: feveral of the Englifin nobility, who poffefled property on the borders of Wales, fourd 
found it worth their while to aid thefe incurfions. Such of the Welth as had feignories or lordifhips here, were invited by the king to acknowledge a dependance on the crown under ample promifes, and full refervation of all their rights and privileges.

All the lands rendered thus dependant on the Englifh crown were denominated Baronics Marcbers; and a kind of palatine jurifdiction was ereeted in them, with power to adminifter juftice in the refpec= tive territories, and the king being fupreme lord, wherever their own jurifdiction failed, redrefs was fought in the Englifh courts of law.

This fcheme was continued with confiderable fuccefs for feveral reigns, till at length a wide furip of frontier country, extending all the way from Brifol to Chefter, which formerly belonged to the Welh, became fubject, under a certain tenure, to the Englifh crown. This tenure was, that in cafe of war, the lords fhould fend to the army a certain number of their vaffals; that they fhould garrifon their refpective cafles, and keep the Welh people in fubjection. In return for thefe fervices, the lords feem to have had an arbitrary and mof defpotic power in their own domains. They had the power of life and death in their refpective courts, in all cafes except thofe of high treafon.

In every frontier manor a gallows was erected, and if any Welfhman paffed the boundary line that was fixed between the two countries, he was immediately feized and hanged: every town within the marches had a horfeman armed with a fword and 
fpear, who was maintained for the exprefs purpofe of taking thefe offenders. If any Englifhman was caught on the Wellh fide of this line, he fuffered a fimilar fate from them.

The Welfh people efteemed every thing that they could fteal from their Englith neighbours as lawful prize. On this account many of the latter were compelled to have their dwellings moated round, and to have palifadoes, or ftakes, on the edge of the moat; and thefe inhabitants every night, for better fecurity, drove their cattle within the fence. If a Wellhman could but get a horfe or cow over the boundary line, he had only to cry out " my own," to prevent the claims of his countrymen, for the horfeman could not dare to follow, left he fhould be hanged.

After the conqueft of Wales by Edward I., the baronies marchers were continued, but under regulations fomewhat different from the former. In the reign of Edward IV. they were governed by a lord prefident, and a council, confiting of the chief juftice of Chefter, and three juftices of the peace of Wales. In cates of entergency, other perions were allowed to be called in.

By a ftatute paffed in the reign of Henry Vill., the principality and dominion of $\mathrm{T}^{\top}$ ales became fornally annexed to the realin of England; and the fame jurifdiction and government, and a fimilar adminitiration of juftice, was adopted. All the iVelfh laws, and mont of their peculiar cultoms and tenures, 
were by this ftatute entirely abolifhed. By this Itatute alfo four new counties were made, Radnor. fhire, Brecknockshire, Montgomeryfhire, and Denbighthire. The marches became annexed partly to England, and partly to thefe new counties of Wales. The prefident and council of the marches were, however, allowed to continue as before, and their general court was holden at Ludlow.

A ftatute, however, was paffed in the year $168 \mathrm{~g}$, the fecond of William III., after the death of the earl of Macclesfield, the laft lord prefident, by which the government of the entire principality was divided between two peers of the realm, who had the titles of lords lieutenant of North and South Wales. From this period the marches were entirely abolifhed*.

* Cotton MSS. in the Britih Mufeum; Vitellius, C. i. Phid. lips's Shrew:bury, note, p. 27. 


\section{H A P. XII.}

\section{OsWestry to Ruabon.}

Cbirk.-- Aquedua. - Cburch. - Memoranda of Dr. Sabbeverell.-Chirk Cafle, and extenfive View. - Anecdute refpecing a whim. fist' Painting of $P_{i}$ iyll Rhaiadr. - Hifory of Chirk Carilie. Wismiranda of Sir Foln Trevor, furmerly Ma,er of the Rolis.Beautiful Scene at New Britge.-Ruabon.-Claurch and Monumerts.-Dr. Laroid Pusuel.

THE viliage of Chirk is fituated on the brow of a hill; and from the numerous coal-works and other undertakings in the neighbourhood, it appears to be a place of fome bufinefs:

The Ellefmere canal paffes within half a mile of the village, and is carriad over the river and vale of Ceiriog by a long aqueduct.

In the cburcls at Chirk there are feveral marble monuments in memory of the Middletons of Chirk caftle : the beft of thefe was erected for fir Thomas IViddleton, one of the commanders in the army of the parliament during the civil wars.

\section{Memoranda of Dr. Sacheverell.}

This well known character, whofe hiftory affords a ftriking inftance of the folly and madnefs of party, 
exalting an obfcure individual, poffeffed but of moderate talents, to the greateft height of popularity, was inducted to the living of Chirk in 1709 .

Sacheverell feems to have little talent, learning, virtue, or religion. Furious in high church principles, he courted the popular favour by impetuoully, and without intermifion, exerting himfelf in the mott outrageous and inflammatory difcourfes againt the perfons then in power, and againt the diffenters, in defence of the doctrines of non-refift. ance and paffive obedience.-A fermon that he preached at St. Paul's was of fuch a nature as immediately to attract the attention of the public; and a fhort time after it was printed, upwards of 40,000 copies were circulated over the kingdom.

The clergy in general were ftaunch in his defence, and, to filence the rifing difcontent, it was thought neceffary for the Houfe of Commons to impeach the author of high crimes and mifdemeanors. His trial was heard in Weftminfter hall, and lafted three weeks. During this time Sacheverel was every day conveyed thither in a coach, attended by the moft tumultuous crowds, who all expreffed the greateft concern for his caufe. He was found guilty, but fuch was the popular fury againt his enemies, that the Houfe thought it expedient to proceed no further than merely to fufpend him from preaching for three years, ordering his fermon to be publicly burnt. 
It was before the expiration of this period that he was prefented with the living of Chirk, for his fentence had not precluded him from taking preferment. In his journey hither he was efcorted through the different towns and villages on the road by fuch muititudes of people, and treated all the way with fuch magnificence, that during the progrefs even of our princes fcarcely greater attentions have been fhewn.-At Wrexham above two thoufand perfons, many of them of family and fortune, met and conducted him; and in his return to Oxford he was brought into Shrewfuliry by nearly five thoufand horfemen, beildes an immenfe concourfe of people on foot. Near Bridgenorth he was met by four thoufand perfons on horfeback and three thoufand footmen, moft of them wearing in their hats white knots edged with gold, and three gilded leaves of laurel: the hedges for two miles from the town were dreffed with flowers; and each of the churches was adorned with flags and colours that colt a confiderable fum of money.

Thefe attentions were highly flattering to Sache. verel; but the favour he had thus obtained at length fubfided, except at thofe times when the populace was momentarily rouied, by his inflamnatory difcourfes, to acts of violence againft the principles of juftice and good government.-He died on the $25^{\text {th }}$ of June 1724 s perfevering in the fame fentiments to the laft.

CHYRK 


\section{Chirk Casthe}

Is about a mile and a half from the village. This building, like that of Powys, ftill retains a mixture of the caftle and manfion. It ftands in an open fituation, on the fummit of a confiderable eminence, which commands an extenfive view, into feventeen different counties. On the exterior it retains much of its primitive afpect. It is a quadrangular ftructure, having five towers, one at each corner, and the fifth for the gatervay, in front. The entrance is into a fpacious court yard, a hundred and fixty feet long, and a hundred broad; and on the eaft fide of this there is a handfome colonade. The principal apartments are a faloon, a drawing-room, and gallery; in the latter of which there is a large collection of paintings, confifing, however, almoft entirely of family portraits.

In a room adjoining to the gallery I obferved a fingular landfcape, in which Piftyll Rbaiadr, the waterfall in Montgomeryfhire, is reprefented as falling into the fea. I afked the caufe of this frange impropriety, and was informed that the painter was a foreign artilt; he had been employed by one of the Middletons to take a view of that cataract, and when the piece was nearly finifhed, it was hinted that a few fbeep, fcattered in different parts, would probably add to its beauty. The painter mifook the fuggeftion, and nettled that a perfon whom he judged ignorant of the art fhould prefume to inftruct

VOL, II. 
him, replied with confiderable tartuess, "You wans fonce frects in it? Tieli, well, I will put you fome ipceps in it!" He foon dafhed out the bottom of the picture, and introduced the fea, and feveral foceps, (lhips) fome of which are reprefented as lying at anchor clofe to the rocks.

There is a dungeon to this caltle, as deep as the walls are high: it is lefcendet by a fight of fortytwo fteps. - The builuing is on the whole low and heavy, and wants nagnitude to give confequence to its appearance.

\section{Histort of Chirk Cistre.}

The prefent fructure was the work of Roger Mortincr, the fon of Roger, baron of Wigmore, founded on the fite of a very ancient fortrefs called Cajtcll Crogen.

John, earl of Warren, and Roger Mortimer, were appointed guardians to the two fons of Madoc ap Griffith, a firenuous partifan of Henry III. and Edmard I. Thefe villains murdered their wards, and appropriated the eftates to their own ufe. Níortimer's frare in the robbery confinted of the lands at Nan-heudwy and Clirk, which belonged to the youngeft boy. At the latter of thefe places he found it politic to erect a place of defence. This he was fuffered to enjoy with impunity till his death, which took place in the tower, after an imprifonment of four years and a half, for the commiffion of fome other crime. The property was even fuffered to. 
continue in the family, and his grandfon fold the caftle to Richard Fitz Alan, earl of Arundel, whofe fon, in the feventh year of Edward III., was made governor, with a confirmation of his father's grant. The Fitz Alans poffeffed it for three generations, after which it paffed to Thomas Mowbray, duke of Norfolk, in right of his wife, the cldeft fifter of Thomas, earl of Arundel. On the ciuke's difgrace and exile in 1397 , it was probably refumed by the crown; for it was afterwards granted to William Beauchamp, earl of Abergavenny, who had married the other fifter of the earl of Arundel. On the marriage of the grand-daughter of this nobleman with Edward Nevil (afterwards lord Abergavenny), it was, in the reign of Henry VI., conveyed into that family. After this it became the property of fir William Stanley, and on his execution it efcheated again to the crown. It was befowed by queen Elizabeth on her favourite, Dudley, earl of Leicefter, on whofe death it became the property of lord St. John of Bletio, whofe fon fold it in 1595 to fir Thomas Middieton, knight *, in whofe family it yet continues.

In the civil wars fir Thomas Middleton revolted from the parliament, and defended his caftle, till one fide, and three of the towers, were thrown down by the encmy's camnon. Thefe he, however, rebuilt within twelve, months, but at an expence of not lefs than eighty thoufand pounds.

- Camden. Fennant, i. 28, 286. 


\section{Memoranda of Sir John Trevor.}

$\Delta$ bout a mile from the village of Chirk is Bryn. kinallt, the family feat of the Trevors, defcendants of Tudor Trevor. 'This was the dwelling of fir John Trevor, maiter of the rolls, and fpeaker of the houfe of commons, in the reigns of James II. and William. Being a man of confiderable talents, he found means to ingratiate himfelf with king James, and during his reign obtained fome popularity.He was, however, too fond of money, and this was the caufe of his expulfion from the houfe in 1695 . An act was panfed for creating a fund towards repayment of the debt due to the orphan charity from the city of I.ondon, and Trevor received from the city a purfe of a thoufand guineas, for his fervices in influencing the houfe in their favour; and it was believed that he had received from the fame quarter other fums to a much greater amourit, of which, however, no proof could be obtained. He wouls? have been impeached by the Houfe of Commons for this offence, had the parliament not been unex. pectedly prorogued. He therefore efcaped with no further punifhment than his difmiffal and difgrace.

Trevor is faid, among his other qualifications, to have been an economif. Of this we have a whimfical ancedote: he one day dined by himfolf at the Rolls, and was drinking his wine quietly, when his confin, Roderic Lloyd, was unexpectedly introduced to him by the fide door. "You rafcal, (faid Trevor 
to his fervant), and you have brought my coufm Roderic Lloyd, efquire, prothonotary of North Wales, marfhal to baron Price, and fo forth, and fo forth, up my back fairs. Takè my coufin Roderic Lloyd, efquire, prothonotary of North Wales, mar. fhal to baron Price, and fo forth, and fo forth; you rafcal, take him inftantly back, down my back fairs, and bring him up my front fairs." Roderic in vain remonftrated; and whilt he was conveying down one, and up the other ftairs, his honour had removed the bottle and glafles *.

Sir John Trevor died in 1696 .

About two miles from Chirk, in the road to Ruabon, I was much pleafed with a view down a woody dell, in the bottom of which ran the river Dee. It was the firft time that I had feen this fream furrounded by thofe romantic features for which it is fo juftly celebrated.

This fcene was interefting, but at

\section{NEW BRIDGE.}

About half a mile farther on, it was greatly exceeded. Out of the road, about a hundred yards above the bridge, fuch a fcene prefented itfelf, that with the pencil of a Claude, I could have fketched one of the moft exquifite landfcapes the eye ever beheld. The river here daned along its rugged bed, and its rocky

* Yorke's Royal Tribes, p. Iog. 
banks clad with wood, where cvery varied tint that autumn could afford added to their effect, caft a darkening fhade upon the ftream. With the green oak, all the different hucs of the an, the elm, and the hazet, were intermingled. Above the bridge arofe a few cottages furrounded with foliage. The evening was calm, and the fmoke, tinged by the fetting fun, defcendat upon the vale, whilft the diftant mountains were brightened by his beams into a fine purple. I fat down on the bank of the river, and contemplated thefe beautis till the declining fun had funk beneath the horizon, and twilight had begun to feal over the landfcape, and blend into one every different thade of reflection, and to cover the wholc face of nature with its fober grey.-I forced myfelf away, and purfued my jour. ney to Ruabon, my intended refidence for the night.

\section{RUABON}

Is a village pleafingly fituated on a rifing ground, and has around it the refidences of feveral perfons of fortune. I fpent two or three days very agreeably in this place, and in little excurfions around the neighbourhood.

The church is a good building : it contains an organ, an inftrument very unufual in Welfh churches, which was given by the late fir Watkin Williams Wynne-At its eait end I obferved a table monument of marble, with the date of 1526 , in memory 
of John ap Elis Euton, and Elizabeth Clefeley, his wife :

A tombe, it is right rich and ftately made, Where two do lye, in ftone and aunciem tride. The man and wife with fumptuous folemne guife, In this rich fort, before the aulter lics ".

His liead on creft, and warlike heinct ftayes, $\Lambda$ lion blue, on top thereof comes out : On lion's necké along his legges hẹ layes, Two grantlets white are lying there about. An auncient fquire he was, and of good race, As by his armes appeeres in many a place: His houfe and lands, not fare from thence, do thow His birth and blood were gleat, righlit long ago $f$.

Befides this, there are four other marble monuments, two of which deferve particular attention. One of thefe is in memory of the late fir Watkin Williams Wynne, and the other of his wife, lady Henrictta Williams Wynne. The latter is reprefented by a beautiful figure of Hope, reclining on an urn: the infcription is on a pedeftal, within a ferpent with its head and tail united, expreffive of eternity. If I am not deceived in the recollection, they are both the workmanfhip of Roubiliac.

\section{Dr. David Powel,}

The Welfh hiftorian, was inftituted to this vicarage in the year 1571, and lies buried here.-He was born about the beginning of the reign of queen

* Not at prefent. $\quad+$ Churelyyard. 
Elizabeth; and after he left Oxford, obtained the living of Ruabon, and was made a prebendary of St. Afaph. Thus rendered eafy and independant in his circumftances, he ftudied with great affiduity the ancient hiftory of Britain. For this he was well qualificd by his extenfive acquaintance with the $\mathrm{W}$ clfh and other languages.-He tranflated into Englifh the Hiftory of Wales written in Wellh of Caradoc of Llancarvan; and edited the writings of Giraldus Cambrenfis, which he illuftrated, and corrected by many learned and valuable notes. He died in 1590 , leaving behind him a large colleçtion of ancient manufcripts. 


\section{$(2 x)$}

\section{H A P. XIII.}

EXCURSion From RuABon to Bangor ISCOEd,

Wynn/ay. - reautiful Scene at Nant y Bele.-Overton. - Conjeciur's on the original Planting of $Y_{e w}$ Tirees in Church Yards. - Bangor Ifcoed, the oldeft Monafery in Britain. - Account of Gildtss Nennius, and of $\mathcal{T}_{y}$ flitio, the Authors of two very ancient Hip.ories of Britain.

$F_{\text {Rom }}$ Ruabon, $I$ wandered into the grounds of fir Watkin Williams Wynne, baronet, at

\section{WyNNSTAY.}

Thefe grounds are brought clofe up to the village; they are well wooded, and about eight miles in circumference, I obferved here fome immenfely large oak, afh, and birch trees: the trunk of one of the oaks was near fifty feet in girth in the fmallent part.

I afcended, by its well-ftaircafe, to the top of a handfome, lately erected ftone column, of very con. fiderable height. I had entertained hopes that from thence I hould have had a fine view of the furrounding country, but was difappointed: the profpect was fufficiently cxtenfive, but in no degree interefting. 
At a little difance from the column there is a toleab'y large pool. 'The rivulet that fupplies it is thrown over fone artifinl rock-work, and forms not an irelcgant cafeade.

The houfe is deficient both in elegance and uniformity, having been erected at differcnt periods, and in different filies of architecture.-From the ancient rampart called Watt's Dyke, which paffes through the grounds, this place was formerly called Wattfay : but, on the mariage of fir John Wyme with Jane, the daughter of Eyton Evans, and heirefs of this property, he changed its name to it ynnfay. He inclofed the park, in the year 1678 , with a ftone wall for decr, and planted the avenucs. Sir John died about forty years afterwards, and was buricd at Ruabon. He bequeathed all his eftates to his relative Watkin Williams, afterwards fir Watkin Wil. llams Wynne, bart., the grandfather of the prefent owner.

This place was anciently the property and refi. dence of Madoc ap Grifith Maelor, the potent lord of Bromfield, and founder of Valle Crucis abbey, near Llangollen.

\section{NANT Y BELE,}

Tlje Dingle of the Martin, within the grounds of Wynnftay, is a deep and wooded hollow. The fides are precipitous and rocky; and the waters of the Dee, which roll along the boitom, are blackened by: the fhady banks, and for the moft part concealed from. 
from the eye of the obferver, by the thicknefs of the foliage. In the diftant background, I obferved Chirk caftle, and the country around it, clad in lively colours; whilf, to the weftward, I had a view of Cartell Dinas Brân, crowning the fummit of its iteep. The whole vale of Llangollen, as far as the town, lay nearly in a ftraight line, and was richly varied with wood, rock, and pafture. The fcene was clofed in the horizon by the far diftant Britifh Alps, which bounded the fight.-From this ftation I proceeded along the bank of the Dee, clambering over hedges and ditches, till I found myfelf at Pen y Llan, the feat of Mr. Lloyd, whence I had another charming view of the country.

I returned to Ruabon, and rambled from thence to Bangor Ifcoed, Bangror under the Wood, a village about ten miles diftant. In this excurfion I pafied through

\section{OverToN,}

A pieturofque little village, feated on an eminence at a fmall diftance from the Dee. Near the bridge I had another fine profpect along this romantic ftream.

In the churchyard I faw feveral fine old yeso trees. Thefe, from their fize and beauty, have been accounted among the wonders of Wales.-If the poems of Offian can be confidered as authority, the cuftom of planting yews in biurying-places was adopted in a very remote period. He thus fpeaks 
of two bvers:-_" Here refts their duf, Cuthullin; thefe lonely yews fprang from thcir tomb, and fhade then from the ftorm." $-A$ thort inquiry into the origin of this cultom may deferve attention.

Were they planted to protect the churches from ftorms?

By a ftatute paffed in the thirteenth year of Edward I., which fettles the property of trees in churchyards, it is ftated that trees were.often planted " to defend the force of the sind from hurting the church." This remark, however, feems, by the context, only to apply to fuch trees as were adapted to the repairs of the church and chancel; which were therefore ordered to be cut down for no other purpofe. The growth of yews is much too flow to allow us to fuppofe that they could be intended as any protection to the buildings; and if we could overcome this objection, we ought to find them more generally adopted, and in great numbers in each churchyard, to be rendered of extenfive ufe.

Were they planted to furnilh bow-ftares?

Our ancient legillators do not appear to have ordered any plantations of yews for this purpofe; although there are various laws which encourage archery, and even enter into minute particulars relative to bows and arrows. On the contrary, our old laws, although full of complaints of the fcarcity and dearnefs of bow-ftaves, inftead of directing the cultivation of the yew at home, oblige merchants to import materials for bows from abroad, - A ftatute 
of the twelfth of Edward IV., recites that the king had perceived, by a petition from the Commons, the great fcarcity and exceflive price of bow-ftares, whereby the practice of archery was greatly difcontinued and almoft lof :. it is therefore ordained that " every merchant ftranger, that thall convey into this land any merchandize of the city or country of Venice, or of any other city, town, or country; from whence any fuch bow-ftaves have been before this time brought, thall bring at the fame time four bow-ftaves for every ton of fuch merchandize, on pain of forfeiture to the king of fix fhillings and eight-pence for every bow-ftaff fhort."-Another ftatute, of the firft of Richard III., informs us, that upon the boriyers reprefenting, that " in times paft good and able fuff of bow-ftaves had been brought into this realm as well by Englifh merchants as ftrangers, whereby the inhabitants, bowyers, might competently live upon fuch ftuff, which they bought at $40 \mathrm{~s}$. the hundred, or $46 \mathrm{~s} .8 \mathrm{~d}$. at the moft ;" but which then, by the feditious confederacy of the I.ombards, who frequented the ports of this realm, were at the ontrageous price of eight pounds a hundred; fo that in fhort time this realm was like to fail, as will of ftuff of artillery, as of workmen thereof; - it was ordered, that no merchant of Ve. nice, nor other which ufed to repair unto this realm with merchandizes of thofe parts, fhould bring into this realm any fuch merchandizes, unlefs he bring at the fame time ten bow-ftaves, good and able ftuff, 
Rtuff, with every butt of malmfy, and with every butt of tire, on forfeiture of thirteen fhilings and eight-pence for every butt of fuch wines, and for cach bow-ftaff fhort.-Even fo lately as the thirteenth year of Elizabeth, the fiatute of the twelfth of Edward IV. was ordered to be duly put into execution; and that all merchants ftrangers, ufing to bring wares into this realm from the eanern countries, as wcll as from the ferenty-two Hanfe towns, fhould thenceforth be comprized and meant under the name of fuch merchanis as were bound by the faid ftatutes. This act recites that archery was a fingular defence of the realm, and an occafion not only of many noble victories, but a very wholefome crercife. - Thus it appears that this country cver depeided on the imported bow-fares for their beft and moft raluable bows, which would not have been the cafe if our church-yards had been planted, and well ftocked with yow-trees, for this purpofe. On further inquiry, it appears that the Englifh yew was of very inferior goodncjs; and our brave archers, who were the giory of the nation, and the terror of its enemies, were compelled to have recourfe to fo. reign materials. - In the "At for Bowyers," of the eighth of Elizabeth, the prices of bows are thus fettled :

Dows neet for men's thoning, being outlandifis yew, of beft fort, were to bear no greater price than 6s. Sd. each.

Bows mett for men's flooting of fecond fort, 3 s. 4 d.

Bows of a courfer fort, called livery bows, $2 s$.

Bows of Enrtifis ycev, is.

Thus 
This we fee that bows of Inglifh yew were only equal in value to the moft inferior of the foreign ones; and they feem rather to have been ufed for domeftic exercife and practice, than to be relied on for deeds of valour in the field of battle. But fappofe the trees planted even for this purpofe, we camot conceive it poffible that all our ftatutes would have been filent on the fubject; and we fhould undoubtediy have had much more confiderable remains of them than now occur.

Sir Thomas Brown, in his Um Burial, fays, " it may admit conjecture, whither the planting of yew trees in church-yards, had not its original from ancient funcral rits, or as an emblem of refurrection, from its perpetual verdure."

An intelligent witer has remarked, that in this country there was formerly a procention (as in $\mathrm{Ca}$. tholic countries there finl is) on Palm Sunday, in memory of the entrance of Chrift into Jerufalem, whiere branches of palm-trees were ftrewed in his way. Te have authority that prims were borne in the procenion with us till the reign of Edward VI. An old manufcript flates, that in this country, from want of olive, that "berith greene leves," paln was ufed to be carried in its ftead. From thefe intimations it is evident that fomething green, called palm, was carried in procofion on Palm Sunday, which is fometimes fo early in the year as the I 5 th of Marcin, and never later than the I 8th of April, when very few plants are in teaf: and in fome church-yards in 
eaft Kent the yew-trees are to this day called palms: It is therefore more than probable that the palms were no other than the branches of yew-trees, which are not only always green, but ufually in bloom about this time; and one or two trees, the number ufually found in each church-yard, would be amply fufficient for the purpofe*

Yeiv-trees may alfo have been confidered emblematical of the ftate of mankind. The leaves having a molt poifonous quality, may have been thought reprefentative of mortality; whilt the durable foliage, and the long period through which they flourith, of two or three centuries, are not unaptly fignificant of immortality and eternity.

\section{BANGOR ISCOED}

Is fomewhat more than two miles beyond Overtor. It is fituated on the baiks of the Dee, which here flows under an elegant ftone bridge of five arches.

This place has its chief celebrity from having been the fite of the moft ancient monaftery in Britain, founded, as the old writers affert, by Lucius; the fon of Coel, and firft Chriftian king of Britain, fomewhat prior to the ycar rot. Lucius formed

* Gent. Mag. vol. 49 .

$\dagger$ Spced's Chronicle, i. 507 . According to the acconnt left ns by Rowlands, Lucins ass converted to the Chritian faits from the preacting of Timothy, the fon of Claudia Rufina, a Britifh female of diftinction, who had been a difciple of St. Pitul. Mona Antign:n, 78 . 
it an univerfity, for the increafe of learning, and the prefervation of the Chriftian faith in this realm; and it produced for an age fo unenlightened many learned men. It is faid by fome writers to have been converted into a monatery about the year 530 by Cynwyl or Congelus, who was created the firft abbot*. Others fay that Pelagius the monk, a native of Wales, who had ftudied here in his youth, after having travelled through France, Italy, Egypt, Syria, and various other countries, was made a bifhop, and on his return to England converted this houre $f$.

The monaftery of Bangor was rich in manufcripts, and univerfally celebrated for its valuable library: and Speed ftates, that from its great age, and the number of its learned men, it was acknowledged to be the parent of all the other monafteries in the world.

At the arrival of Auguftine, who was miffioned about 596, from pope Gregory I., to convert the Englifh Saxons to Chriftianity, this monaftery appears to have been in a very flourifhing ftate. There were at this time as many as 2400 monks: a hundred of thefe, in turns, paffed one hour in devotion, fo that the whole twenty-four hours of every day were employed in facred duties $\ddagger$. Bede fays there

* Jones's TVelir Bards, p. ı.

+ Holinfhed, i. 26. 148. Rowlands, I79. Some writers have afferted that Pelagius was never in this kingdom.

$\ddagger$ Speed, i. 206 .

VOL. II.

$\mathbf{k}$

were 
were juft fo many, that being divided into feven parts, each of thefe contained three hundred men, which, with their proper rulers, paffed their time alternately in prayer and labour*.

The monks of Bangor were diffenters from the Romifh church; and, on a conference betwixt Auguftine and its governors, the imperious monk demanded of them that they fhould keep the feaft of Eafter at the fame time the papifts did; that they fhould adminifter baptifm according to the ceremonies of the church of Rome; and "preach the word of life with him and his fellows." In other things, he faid, they would be allowed to retain their ancient cuftoms, infolently concluding, that " if they would not accept of peace with their brethren, they thould receive war from their enemies, and by them, without referve, fhould fuffer death t." They refufed obedience to his injunctions, and refolutely maintained the original rites of their church. Shortly after this period followed the dreadful maffacre of above twelve hundred of the monks by Ethelfrid, king of Northumbria, at the memorable battle of Chefter. This unmanly flaughter the Britifh annals and fongs afcribe to the infligations of Auguftine.

Not long after this event the monaftery became neglected, and went entirely to decay. William of Malmbury, who lived fhortly after the Norman con-

* Bede, lib. ii. c. 2. p. II-I13. Holinned, i. I5.

+ Holinhed, i. 103. 
queft, afferts, that even in his time, there remained only fome relics of its ancient magnificence: there were, he fays, fo many ruincd churches, and fuch immenfe heaps of rubbih, as were not elfewhere to be found *.-Leland fays of it, in the reign of Henry VIII., that its fite was in a fertile valley on the fouth fide of the Dee; but that the river having. fince changed its courfe, then ran nearly through the middle of the ground on which it ftood. The extent of its walls, he fays, was equal to that of the walls round a town; and the two gates, the names of which had been handed down by tradition, had been half a mile afunder. Within the memory of perfons then living, the bones of the monks, and pieces of their clothes, had been ploughed up, in the cultivation of the ground, as well as pieces of fquared ftones, and fome Roman money $t$.

\section{Gildas Nennius,}

A difciple of Elbod, bifhop of North Wales, was abbot of Bangor in the feventh century. This early writer was the author of a hiftory of the Britons in Latin, copies of which are yet extant. All the copies in the public libraries under the name of Nennius, Gildas Minor, Gildas Nennili, \&rc. owing to the ignorance of tranfcribers, are, however, faid to be extremely inaccurate. - This hiftory, with feveral others, was publifhed by Dr. Gale in $169 \mathrm{I}$; but his

* Scriptores poft Bedam, 294. + Leland's ltin. v. 30.

K 2 copy 
copy was very incorrect, and the notes and various readings, it is faid, tend more to confound than infruçt. The editor left alfofeveral parts of the work unpublifhed, on account of the facts there related being found in the hiftory written by Ranulph Higden, an author five hundred years fubfequent to Nennius. This was improper, and, to the character of Nennius, unjuft.-Some hiftorians have fuppofed that the work was commenced by Gildas, the author of the epiftle "De Excidio Britannix," and that it was only continued by Nennius; for it is quoted under the name of Gildas by Tyfilio, and many of the Englifh hiftorians. In the preface Nennius declares it to be his own entire compofition, from traditions, writings, and ancient Britifh monuments, as well as from the works of foreign authors.-It appears that the name of this writer, before he became abbot, was Gildas, but on his preferment he took that of Nennius. The latter, therefore, was probably only his ecclefraftical name; and the various titles of Gildas Nennius, Gildas Minor, Gildas Sapiens, \&c. appear to have been intended, by the tranicribers, to diftinguifh his work from the works of Gildas ap Law, the North Briton. This circumftance obrained for him by Polydore Virgil, and others, the appellation of Pfeudo Gildas, or The Falfe Gildas, without the leaft apparent confideration that there might have been two ancient writers of the lame liame: 


\section{Trsilio.}

While I am fpeaking of the monattery of Bangor, and its eminent men, I ought by no means to leave this writer unnoticed. Tyfilio was a Britifh bifhop, the fon of Brochwel Yfythroc, prince of Powis, and was nearly contemporary with Nennius. $\mathrm{He}$ was the author of a Britifh hiftory intitled Brut y Bren binoedd, or the traditions of the Britifh bards. It commences with the defcent of the Trojan colony, and ends with the reign of Cadwaladr, the lat king of the Britons. This hiftory, about the year 1150 , fell into the hands of Galfrid Arthur, or Geoffry, archdeacon of Monmouth, and afterwards bihop of St. Afaph, who tranfated it into Latin, inferting in his tranflation all the monkifh fables that he could collect. In this ftate the work took the name of the tranflator, and has fuffered the moft violent abufe by all the Englifh, fince the time of Camden, that have written on the Britifh hiftory; and by various French and Dutch writers. This, however, has been done without any acquaintance with the orig:nal work in the Britih language, which is effentialiy different from the tranflation both in general matter, and in the ftatement of facts. 


\section{( 134$)$}

\section{H A P. XIV.}

\section{RUABON TO WREXHAM.}

Erdilig.-Wrexbam.-Church and Monuments.-Anecdote of Elitis rale.-Wrexban Fair.-Trade and Manufacories.

I LEFT Ruabon, and proceeded on my journey towards Wrexham. In order to pafs through the grounds of Erddig, belonging to Philip Yorke, efq.* I left the carriage-road, and went along a foot-path, over the meadows on the right. I obferved confiderable tafte difplayed at Erddig, but all the efforts of art are fo infinitely inferior to the majeftic opera. tons of nature, which I had lately feen in fo much variety, that I cannot fay I derived much pleafure from thefe grounds. - Watt's Dyke runs through them; and not far diftant is the fragment of a wall, conjectured to have been part of a Roman fort.

\section{WREXHAM}

Is a populous market town, and of fuch fize and confequence as to have obtained the appellation of the metropolis of North Wales. The ftreets and

*-The author of a valuable liftory of the Five Royal Tribes of North Walcs. 
buildings are in general good; and the adjacent country is fo beautiful, as to have induced many families to fix their refidence in its vicinity. The centre ftreet, in which the market is held, is of confiderable length, and of unufual width for an ancient town. The common hall is a large and convenient building. This place was known to our Saxon anceftors by the name of Wrightedham, or Wrightlefham. A few centuries ago it was noted as the refort of buckler, or thield makers *.

The church was formerly collegiate, and is yet a molt elegant ftructure. On the exterior it is richly ornamented with gothic fculpture. The tower, which is about a hundred and forty feet in height, is particularly beautiful. On three of its fides there have been ftatues as large as life, of no fewer than thirty faints: two have been deftroyed by falling from their niches. Mifs Seward, in her verfes on Wrexham, has finely expreffed the elegance of this building:

Her hallow'd temple there religion thews,

That erit with beauteous majefty arofe,

In ancient days, when gothic art difplay'd

Her fanes in airy elegance array'd,

Whofe namelefs charms the Dorian claims efface,

Corinthian fplendor and Ionic grace.

* "Wrexham, truly called Wrightlefham, is the only market town of Welfh Maelor, having a goodly church collegiate : there longith no prebendes to it, though it be collegiated. There be fum merchauntes and good bokeler makers:" Lheland's Itin. v. $\$ 2$. 
The interior of the church is phain, but exceedingly neat, being devoid of the load of ornaments common in gothic churches. It contains, among other monuments, two of the elegant workmanfhip of Roubiliac. One of thefe, having the date of 1747, was erected to the memory of Mary, the Naughter of fir Richard Middleton. A female figure is reprefented in the act of burting from the tomb: the countenance is truly angelic, and the mixture of furprize and admiration is fo delicately, and at the fante time fo firmly expreffed, that after gazing for fome moments ftedfaftly on the face, I could almost have funcied it more than ftone. The fainted maid,

Amid the burfting tomb

Hears the laft trumpet fhrill its musy gloom,

With fmile triumphant over death and time,

Lifts the rapt eye, and rears the form fublime.

Againt the wall, an ancient pyranid, a building, from its folidity, calculated to refint the efforts of tim:, is repreferted as falling into ruin. The ridiculous little figure blowing the trumpet might have, been omitted without any derogation from the merit of the fculpture. On the whole, however, it is fo uncommonly beautiful, as to demand the admiration

- of every lover of the art.-The other piece of Roubiliac's performance, is a medallion containing two profile faces of the reverend Thomas Middleton, and Arabella his wife.-Nearly oppofite to the former of thefe monuments there is a recumbent figure 
of Hugh Bellot, of the ancient family of Morton in Chefhire. He was bifhop of Bangor, was afterwards tranflated to the fee of Chefter, and died in the year 1596 . Bellot was one of thofe divines who adhered to the monaftic aufterities long after both law and cuftom had rendered them unneceffary : during the whole of his life he would never admit a female into his family *.-There is under the belfry an antique monument, which was fome years ago difcovered in the ground by the workmen who dug for a foundation for the iron gates of the church-yard. The figure is of a knight in complete armour; his feet reft on forne kind of animal, and round his thield there is an infcription, but this is at prefent illegible.

The altar-piece is a fine painting of the inftitution of the facrament. It was brought from Rome, and given to the church by Elihu Yale, efq. a native of America, who went on fpeculation to the Eaft Indies. Of this perfon, it is recorded by one of the travellers in India, that he ordered his groom to be hanged for having ridden his horfe on a journey of two or three days for the fake of his health: he was tried for this crime in the Englifh courts, and efcaped with a high pecuniary punifhment t. He died in London in the year 1721 , but was int rrred in this church-yard with the following infcription on his tomb:

- Yorke, 22.

† Harris's Collection of Voygges and Travels, i. 917. 
Born in America, in Europe bred,

In Afric travelled, and in Afia wed;

Where long he liv'd and thriv'd-in London dead.

Much good, fome ill he did, fo hope all's even,

And that his foul through mercy's gone to Heaven!

You that furvive and read this tale, take care

For this moft certain exit to prepare,

Where bleft in peace, the actions of the juft

Suell fweet, and bloffom in the filent duft.

The prefent church at Wrexham was finifhed, except the tower, before the year 1472 : the latter, from a date that there is upon it, does not feem to have been completed till about thirty-four years afterwards. In 1647 , during the civil wars, this venerable building was ufed for fome time as a prifon, and feveral of the committee-men were confined in it by the parliament's foldiers, who had mutined for want of pay *

At this town there is a noted annual fair, held in the month of March, which lafts nine days This is frequented by traders from various, and even very diftant parts of the kingdom. The com. modities brought by the Wellh people are chiefly flannels, linen, linfey-woolfey, and horfes and cattle in abundance. Traders from other parts bring Irifl linen, Yorkihire and woollen cloths, and Manchefter and Birmingham goods of all kinds. For the accom. modation of thofe who have goods to fell, there are two fquares, or areas, furnifhed with little hops or boothst.

* Whitelock, 243. + Aikin's Manclefter. 
The two principal inns are the Eagles and the Red Lion, both good houfes. At the former I had excellent accommodations, and experienced the molt obliging treatment.

In the neighbourhood of Wrexham there are feveral manufactories of military inftruments; and in particular a large cannon foundery not far from the town. 


r: (140)

\section{H A P. XV.}

Excursion from Wrexham to Holt.

Village of Holt. - Cafle. - Hiffory of the Cafile.

From Wrexham I made an excurfion to Holt, an obfcure village on the weft bank of the Dee, about fix miles diftant. This was once a market town, and a place of fome confequence; and it fill continues to be governed by a mayor and aldermen. The former is ufually fome gentleman of refpectability who refides in the neighbourhood.-The town was incorporated in the year 1410 , by a charter of Thomas earl of Arundel, which, however, reftricts the burgeffes from being Welfhmen:-the charter runs in this fingular form: "To the burgeffes of our town, and to their heirs and fucceffors, being Englifomen." This arofe, no doubt, from the ha. tred which the lords marchers entertained towards the Wrelf people, on account of the infurrection of their hero Glyndwr, at that time fcarcely fup. preffed *.

This place has alfo the name of Lyons. The cafle was anciently called Caftrum Leonis, which

- Pennant, i. 210. 
appellation Camden conjectures to have been derived from the Roman twentieth legion having been ftationed at a little diftance higher up, and on the other fide of the river.

The two villages of Holt and Farndon are divided only by the Dee, and have a communication by a very ancient bridge of ten arches.-All the fonery of this neighbourhood is flat and unpleafant. The Dee flows through meadows, without any of the beauty or grandeur of rocks, or foliage, that adorn its banks in the more mountainous parts of the country.

\section{Hol t Castle}

Was fituated clofe to the river, and deferded on three fides by a moat forty or fifty yards wide, cut out of the folid rock: the prefent remains confif of little elfe than rock, for this originally feens to have formed the firft eight or ten yards of the caftle. The ftone ufed in the building appears to have been that obtained in making the moat.-The fortrefs confifted of five baftions, of which four were round, and the remaining one, facing the river, fquare: The entrance was by a drawbridge on the weft fide. So little of the mafonry is left, that in the prefent ftate it is impofible to form any idea of its ancient ftrength. The fite is by no means extenfive; and as it ftood on a piece of ground level with the town, it muft have had its principal ftrength in the deap and perpendicular fides of its moat. 
The lands of Holt and Chirk, in the reign of Henry III., and the commencement of the reign of Edward I. were the property of Madoc ap Griffith, a native of Wales who had efpoufed the Englifh caufe. On the death of Madoc, two fons were left, both of them under age; and Edward gave one of them to the guardianfhip of John, earl of Warren *, and the other to the care of Roger Mortimer, the fon of lord Mortimer of Wigmore. To the former boy belonged the lordhip of Bromfield and Yale, in which Holt ftands, and the caftle of Dinas Brân ; and to the other the property of Chirk and Nanheudwy.-The villainous guardians, to difburthen themfelves of their charge, and get poffeffion of the eftates of the children, caufed them both to be murdered. Their inhumanity, fo far from meeting its juft reward, was freely pardoned by Edward, who came in for a thare of the fpoil. He confirmed to Warren the caftle of Dinas Brân, and the lordhip of Bromfield and Yale; to Mortimer he gave the property of Chirk; and the caftle and demefnes of Caergwrle, or Hope, he referved to himfelf. Warren and Mortimer immediately began to fecure their poffefions by erecting on them places of defence. The latter built Chirk cafle, and Warren com-

- Camden is wrong in ftating that John earl of Warren was guardian to "Nadoc, a Britif prince ;" as it was the far. of Madoc that had been entrufted to his protection. 
menced this fortrefs, but dying foon afterwards, it was finifhed by his fon *.

In the ninth year of Edward II., John earl Warren, the grandfon of the founder, having no iffue, gave this cafle, with that of Dinas Brân, and the lordihip of Bromfield, to the king. He was foon after divorced from his wife, and he obtained a regrant of them to himfelf, and Miatilda de Nereford, his miftrefs, for life, with remainders to his illegitimate children, and their heirs. Matilda was the laft furvivor, and therefore at her death, in the fol lowing reign, the property reverted to the crowis. It was, not long afterwards, given to Edward Fitz Alan, earl of Arundel, who had married the fifter of the late owner. In this family it remained for three generations; but on the execution of Richard it appears to have been forfeited to the crown. When, in I 399 , after this event, Holt caftle was delivered to the duke of Hertford, there were found in it jewels to the value of two hundred thoufand marks, and a hundred thoufand marks in money. Thefe had been depofited there, as a place of fafe cuftody, by the unfortunate Richard II. previounly to his expedition into Ireland $t$.

The eftates and title were reftored in the fucceeding reign, and they once again efcheated to the crown. Henry VII. granted them to fir William

* Gibfon's Camden, 682. Aylofi's Rotuli Wallix, $8 \mathrm{r}$. Powel, 213. Carte, ii. 193. Pennant, i. 217. Yorke, 63. + Holinged, ii. 500.

Stanley; 
Stanley; but on his execution refumed them, and took in this cafle plate and money to the value of above forty thoufand marks, which Stanley had obtained from the plunder of Bofworth Field *.

The lordhip of Bromfield and Yale afterwards became the property of Henry Fitzroy, duke of Richmond, the natural fon of Fenry VIII.; and in the reign of Edward VI., of Thomas Seymour, brother to the protector Somerfet, who formed here a magazine of military ftores. On his execution it once more fell to the crown $t$.

During the civil wars Holt caftle was garrifoned for the king, but in 1643 was feized by the parlia. ment. It was afterwards retaken, and in February I $645^{-} 6$ was again befieged by the parliament's forces. The governor, fir Richard Lloyd, defended it for more than a month with the utmolt bravery, but was at length compelled to furrender. Towards the end of this year this caftle, with four others, was difmantled by order of the parliament $t$.

The lordhip of Bromfield and Yale is at prefent the property of the crown; and fir Watkin Wil. liams Wynne, bart. is the fteward.

The inhabitants of Holt contribute with thofe of Ruthin and Denbigh, towards fending a member to parliament,

* Fuller's Worthies of Wales, 34. + Pennant, j., 212 .

f. Whitelock, $77 \cdot 192.197 .231$. 


\section{$(145)$}

\section{H A P. XVI.}

\section{Wrexifam to Mold.}

Romantic Glen.-Caergzurle. - Hiffory of Caergworle Cafle.-Mold. - Church.- Hiffory of Moll Cafle. - Account of Maes Garszon, and the "Alleluia" Viclory.

A вout five miles from Wrexham I paffed through a romantic glen, which would have had confiderable picturefque effect, if this had not been deftroyed by feveral white-wafhed cottages obtruding themfelves on the fight from among the trees. A little beyond this fcene I paffed a neat bridge of a fingle arch, which appeared very beautiful, accompanied by the ruftic cottages overhadowed with trees on the bank of the ftream.-The country I now journied through was fomewhat mountainous; but beyond this vale it became again flat and uninterefting.

\section{CaErgwrle}

-Comes right now to pafie my pen,

With ragged waulles, yea all to rent and torne:

As though it had been never knowne to men, Or careleffe left, as wretched thing forlorn;

Like beggar bare, as naked as my nail, It lies along, whofe wrecke doth none bewayle *

* Churchyard's Worthines of Wales, 122. VOL. II. 
Cacrgwrle, like Holt, was once a flourifhing town, but it is dwindled into an infignificant village.-Its parifh church is about a mile diftant.

There is good reafon for fuppofing that Caergwrle was a Roman ftation, probably an outpoft to Deva. Camden difcovered here an hypocauft, hewn out of the folid rock, fix yards and a quarter long, five yards broad, and fomewhat more than half a yard in height. On tome of the tiles were infcribed the leticrs LEGIO $\mathrm{xx}$, which feem to point out the founders. This is further corroborated by the name of the place. Caer gawr lle, the camp of the great icgion; Gawr lle being the name by which the Britons diftinguifhed the twentieth legion *.

The cafte ftood on the fummit of a high rock. Its prefent remains are very inconfiderable; they are, however, fufficient to indicate that it could never have been a fortrefs of any great importance $t$.

The founder has not been afcertained; but from its confruftion it has been evidently of Britiih origin. -In the reign of Edward I. we find it pofferted by the Englin crown, for that monarch beftowed it, along with the lordfhip of Denbigh, on David, the brother to prince Llewelyn. Whilf in his hands,

* Gibfon's Canden, 683. Fennant, i. 432.

+ " The town of Hope, now decayed, was fumtime burgefid and privileged, and ys caulled in Walfch Cairgorles. Ther flond yet grete waulles of a caftle fet on an hylle, wher be diggid grood mill ftones of a blue git." Leland's Itiu. v. $3^{8 .}$

Roger 
Roger de Clifford, jufticiary of Chefter, cut down the adjacent woods, and endeavoured to wreft the caftle from its owner: this, however, he was prerented from doing by the timely interference of the king. -When David, in 1282 , infidiounly took up arms with his brother againft his former benefactor, he left a garrifon of fome ftrength in the caftle; but it was befieged by a divifion of the Englifh army, and was fhortly afterwards furrendered to them *.

In the preceding account of Holt I have remarked that Caergwrle caftle was excepted from the grant which was made to John earl of Warren of the property of one of the children of Madoc ap Griffith $\dagger$. Edward annexed it, with the tract of land in which it is fituated, to Flintfine: it continued to form a part of this county till Henry VIII. feparated, and added it to the county of Denbigh. It was, however, not long afterwards reitored to its proper county.

Edward I. after the furrender of the garrifon that David left in it, gave the caftle to his confort, Eleanor, from whom it acquired the name of gueen Hope. She lodged here in her journey to Caernarvon; and either during lier abode in the caftle, or very fhortly afterwards, it was by fome accident fet on fire, and burnt $\ddagger$.

$$
\begin{aligned}
& \text { * Powel, } 350 \text {. † Carte, ii. } 193 . \\
& \ddagger \text { Camden. Yorke, } 63 .
\end{aligned}
$$


In the firt year of the fucceeding reign, this cafte and manor were granted to John de Cromwell, on condition that at his own expence he flould repair the caftle *.-Sone years afterward they wore given to fir John Stanley.

The town of Hope receired its firft charter from Cdward the Black Prince, in the year 1351 . By this charter it is directed that the conftable of the caflle for the time being fhould alfo be the mayor, and! he was to choofe annually from the burgeffes tiio perfons as bailiffs. - All the privileges which the inhabitants cnjoyed from this charter were afterwards confrmed by Richard II.-Caergwrle and Hope, in conjunction with Flint, Cacrwys, Rhycldlan, and Orerton, fend a member to parliament

\section{MIOLD}

Is a fmail market torm, confrifing principuliy of on long and wide ftreet.

The clourch is a neat building, ornamented all romint the top of the outfide walls with gothic carvings of animals. The body was erected in the reign of Henry VII., but the tower is of more modem date. The pillars in the interior are light and elegant, and its whole appearance was exceedingly neat. There is a good monument of Richard Davies, efq. of Llanerch, who died in the year $1,28$.

* Dugdalc's Baronagre, ii. 44. + Pennant, i. +35 . 
He is reprefented in an upright attitude, but, unfortunately, the figure has loft its nofe from an accidental ftone thrown through the window.-The epitaph on Dr. Tilliam Wynne of Tower, fome time fellow of All Souls college Oxford, who died in the year 1776 , deferves a place here, not from its eccentricity, fo much as its recording an example of an exprefs direction againf interment within the walls of the church, which ought to be generally followed:

In conformity to ancient ufage;

from a proper regard to decency, and a concern for the health of his fellow-creatures, he was moved to give particular directions for being buried in the adjoining church-yard, and not in the church.

And as he fcorned flattering of others while living, he has taken care to prevent

being flattered himfelf when dead, by caufing this fmall memorial to be fet up in his life time.

God be merciful to me a finier.

There is alfo in this church an ancient cenotaph to the memory of Robert Warton, or Parfew, who was abbot of Bermondey, but in 1536 was tranflated to the fee of St. Afaph. He was interred at Hereford, but having been a confiderable benefactor to the church of Mold, this cenotaph was erected as a grateful memorial of his beneficence. 


\section{Mold Castie.}

From the church-yard a lofty mount called the Bailey Hill, was pointed out to me as the fite of the caftle*. Of the building there are not now, I believe, the fmalleft remains. 'The hill was planted on its fummit, and round the bottom, with larches, firs, and other evergreens.

The caftle appears to have been founded during the reign of, William Rufus, by Robert Montalt, the fon of the high fteward of Chefter. From him the place received its name of M.tont Alt, or De Monte Alto + .

In the year I 44 it was feized and demolifhed by Owen Gwynneld, prince of Wales, and in little more than a century it appears to have feveral times changed owners. At length, in 1267 , Griflith ap Gwenwynwrin wrefted it from the hands of the Englifh, and again deftroyed it + . It was foon rebuilt, and reflored to the barons of 'Montalt.-in 1327 , the lat baron having no iflue, conveyed it to Ifabel, the queen of Edward II., for life, with re-

* "At the north end of Byly ftreate, appere ditches and hilles, yn token of an auncient caftel, or building there. It is now called Mont Brenebyly." Lcland's Itin. v. 35 .

+ This was alfo applicable to the elevated fituation of the caftle, and was fynonymous with the Welfh name $\gamma_{i}$ H'ycilgrig. See I) ugdale's Baronage, i. 527 .

\$ Puwel, 199.326, Matr. Paris, 576. Matt. WTeftm. 190. Holinhed, ii. 23 \%. Wynne, 279. 
mainder to John of Eltham, a younger brother of Edward III. But on his death, without iffue, it reverted with his poffeffions to the crawn.

The lordhip became fome time afterwards the pro. perty of the Stanley family. The earls of Derby poffeffed it till the execution of James, after which it was purchafed, along with the manor of Hope, by fome perfons whofe names I have not been able to learn, who enjoyed them till the reftoration. At the conclufion of the civil wars, the earl of Derby agreed to pay eleven thoufand pounds for thefe manors; but afterwards retracting, the king ordered the former purchafers to be confirmed in their poffeffion. The Derby family, however, by fome means regained the manor of Hope, but that of Mold was loft to them for ever *.

\section{Maes Garmon.}

About a mile weft of Mold, and not far trom Rhual, the feat of the Griffiths, is a place which to this day retains the name of Maes Garmon, The Field of Garmon or Germanus. On this fpot, in Eafter week 448 , was fought the celebrated battle between the joint forces of the Picts and Scots againft the Britons, headed by the bifhops Grermanus and Lupus, who had about two years before been fent into tbis kingdom. Previoufly to the engragement, Germanus inftructed the foldiers to attend

* Pennant, i. $42 \sigma_{\text {i }}$ 
to the word given them by the priefts on the field of battle, and to repeat it with energy through the whole army. When the forces were prepared for the critical onfet, that was to decide the important fate of the day, Germanus pronounced aloud $A_{L}$ LELUIA! The priefts repeated it thrice, and it was afterwards taken up by the voices of the whole army, till even the hills reverberated the found. The enemy, confounded, affrighted, and trembling, fled on every fide. The Britons purfued, and left few alive to relate the difmal ftory. Moft of them fell by the fword, but many threw themfelves into the adjoining river, and perifhed in the flood*. This victory has been called by all the hiftorians Victoria Alleluiatica. - A pyramidal ftone column, erected on the fpot in 1736 by Nathaniel Griffith, efq. of Rhual, commemorates the event in the fol. lowing infcription:

Ad annum

$\operatorname{cccc} x i$

Saxones Pictique bellum adverfus

Britones junctis viribus fufciperunt

In lac regione, hedieque Mars Garmos

Appellata: cum in prrelium defcenditur,

Apotolicis Britonum ducibus Germano

Et Lupo, Christus militabat in caitris;

Alleluia tertio repetitum exclamabant,

Hodie agmen terrore proiternitur;

* The river is at prefent fo very finallow, that it would fcarcely drown a dog: this battle might have taken place during an overflowing of the water in confequence of heavy rains. 


\section{Triumpliant}

Hoftibus fufis fine fanguine;

Palmâ fide non virious obtentâ.

MP.

In victorix Allelviaticr memoriam.

N. G.

MDCCXXXY1.

The date of this battle feems to have been mifsaken both by Mr. Griffith and Mr. Pennant, who each fix it in the year 420. Matthew of Weftminfter, from whofe work the preceding account is extracted, fays exprefsly that it took place in $44 \delta$, and that Germanus and Lupus did not arrive in this kingdom tili about two years before this time*. He mentions nothing of the Saxons having any thare in the bufinels; nor indeed does it appear very probable that they fhould, fince their army was not introduced by Vortigern till the following year. What has been faid, that the Saxons here engagea might have been fuch as came over on fome predatory excurfion, prior to the invitation of Vortigem, can have little validity when fuch evidence both irect and circumftantial is to be adduced to the contrary. The arrival of the Saxons prior to that period, feems however of much lefs inportance in the proof than the arrival of the bilnops, for they evidently were not in the kingdom till twenty-fis years after the generally fuppofed time of the event.

* Matt. Weft. 152-15\%. In Rymer, i. $4 \div 3$, it is faid to have taken place about the year 447 . 


\section{( 154$)$}

\section{H A P. XVII.}

Mold to Ruthin.

Vale of Clayyd.-Llanrbaiadr. -Cluurch. - Epitaph recording a Defcent from one of the Welfs Princes. - The Well at Llanrbaiadr.Rutbin.-Church.-Cafle. - Hiflory of the Town and Cafle.

$F_{\text {Rom }}$ Mold I went again to Denbigh, in order to purfue a regular track through the remainder of North Wales to Shrewfbury, which was the place I had fixed as the termination of my pedeftrian ramble, and from whence I intended to take coach immediately to London.

I was highly delighted with my walk along the vale of Clwyd, from Denbigh to Ruthin. The, views all the way were of the elegant, rich, and here picturefque vale, bounded by the diftant Clwyddian hills. The day was peculiarly favourable to this kind of fcenery; it was dark and hot, and the rolling clouds that hung heavily in the atmofphere. tinged the mountains with their fombre fhade, which gare an indefcribable richnefs to the fcenes. 


\section{LLANRFAIADR.}

I arrived at Llanrhaiadr, The Village of the Cataract ${ }^{*}$, which is fituated on a finall eminence in the midft of this fertile vale.

The clourcls is a handfome ftructure, with a large and fomewhat elegant eaft window, containin' a reprefentation of the genealogy of Chritt from Juti. The patriarch is painted as fprawling upon his back, with the genealogical tree growing from his ftomach. -I was wandering carelefsly about this building, when I caft my eyes on a tombltone containing the following infcription, which affords a memorable inftance of the pride of anceftry which is inherent in the Welfh character:

Heare lyeth the body of John, ap Robert of Porth, ap David, ap Griffith, ap David Vaughan, ap Blethyn, ap

Grifith, ap Meredith, ap Iorworth, ap Llewelyn, ap Ieroth, ap Heilin, ap Cowryd, ap Cadvan, ap Alawgwa, ap Cadell, the

King of Powis, who departed this life the $x x$ day of March, in the year of our Lord God I6 43 , and of his age $x \mathrm{cr}$.

* This is the literal tranflation of the Wein word: wherece the name can have been derived I know not, as there is wo cataract near the place. 
About a quarter of a mile diftant there is a cclebrated fpring called Ffynnon Dyfnog, The Well of Dyfnog. There was on this fpot a bath, and formerly a chapel dedicated to this Welfh faint.

\section{Ruthin.}

I proceeded on my journey, and found the fcenery all the way to Ruthin, The Red Fort, extremely beautiful.- This place, like St. Afaph and Denbigh, is pleafantly fituated on a confiderable eminence nearly in the middle of the Vale of Clwyd. At a little difance behind the town, the mountains feem to clofe up the end of the vale. From difierent fituations in the out?hirts of the town I had feveral fine profpects of the adjacent country. The little river Clwyd runs through this place, and is here fcarcely three yards acrofs... Ruthin is a large and tolerably populous town, having two markets in the week, one on Saturday for meat, and the other on Monday principally for corn. The county-gaol for Denbighthire is here: it is a neat and well-conftructed building.

The church was originally conventual, belonging to a houfe of Bon-hommes, a fpecies of Augutine monks. It was made collegiate in 13 Io by John, the fon of Reginald de Grey, lord of Dyffryn Clwyd, who endowed it with upwards of two hundred acres of land, granted to it many privileges, and eftablifhed feven regular pricfts, one of whom was to ferve the chapel of the garrifon. In this ftate it probably 
continued till the diffolution, but neither Dugdale nor Speed have mentioned its valuation.-The apartments of the priefts were joined to the church by a cloifter, part of which is built up, and now ferves as the manfion of the warden.-The tower is of a much later date than the reft of the building.

It is believed that there was formerly a borfe of white friars in this place: of this there is nothing left except the name.

\section{Ruthin Castae}

Iras fituated on the north fide of the town, and on no great elevation. Its prefent remains are a few foundations of the walls, and the fragments of a tower or two. Some parts of the building appear to have been of valt ftrength and thickness. The fione of which it was formed was of a brick red colour, whence the place had the name of Rhudd Dulin (or Dinas), The Red fort. On the area of the caitle there is at prefent a meaclow, and in another. part a five's court, and bowling-green. The walls alord a fine profpect of the vals. - The following is a defcription of this fortrefs during the fixteenth century, previoufly to its demolition:

This cafte ftands on rocke much like red tricle, The dylses are cut with tool through ftony cragge, The towers are high, the walls are lurge and thicke, 'The worke itfelf would frake a fabje:t's bagge,

If he were bent to build the like a raine.

It refts on mount, and lookes $c^{\prime} \mathrm{cr}$ wood and phayc, 
It hath great ftore of chambers finely wrought "I'lat tyme alone to great decay hath brought.

It Rews within by double walls and wayes, A deep device did firt erect the fame;

It makes oure worlde to think on elder dayes Becaufe one worke was form'd in fuch a frame.

One tower or waull the other anfwers right, As though at call each thing fhould pleafe the fight:

'The ocke wrought round where every tower doth ftand Set forthe full fine by head, by heart, and hand.

The town and caftle of Ruthin appear to have been founded by Reginald Grey, fecond fon to lord Grey de Wilton, to whom Edward I. had given nearly the whole of the vale of Clwyd, as a reward for his active fervices againft the Weinh. His pofterity, who received the title of earls of Kent, refided here, till earl Richard, having diffipated his fortune by gambling, fold the whole property to king Henry VII.-From this time the caftle, being unroofed, fell into decay, till, along with large revenues in the vale, it was beftowed by the bounty of queen Elizabeth, on Ambrofe earl of Warwick. By him it was repaired, and again rendered tenable.

During a fair that was holden at Ruthin in the year I 400, the foldiers of Glyndwr fuddenly entered the town. They fot it on fire in various places, plundered the merchants, and again retired in fafety to the mountains. 
ne civil wars the caftle was retained by the royalift party till February $1645^{-6}$ : it was then attacked, and, after a fiege of near two months, was furrendered to general Mytton. Colonel Mafon was made governor; but in the fame year it was ordered by the parliament to be difmantled. 


\section{G H A P. XVIII.}

\section{Ruthin to Llangolien.}

The Vule of Crucis. - The Pillar of Elifeg. - Valie Crucis Aobeg. Singular Explanation of an Infcriplion.-Llangollen.-Llangollen Bridge and Clutrch. - Plis Neruydd, the Seas of Lady Eleanor Butler and Mifs Ponfonby. - Cafell Dinas Brân.-Craig Eglwyfeg.-Hiifory of Calicll Dinas Brân. - Myfansuy Vechan. - Excurfion round the Vale of Llingollen.-Aqueduct near Pont $y$ C.VJylite. - Views. - The Inn at Llangollen.

I LEFT Ruthin early in the morning. The clouds began to collect, and a drizzly rain came on, which lafted without intermifion till I arrived within four miles of Llangollen. I thus loft feveral probably fine views from the high mountains that form the eaftern barrier of the vale of Clwyd, over which the road winds. During the greateft part of this journey I was fo enreloped in clouds and mift, that I could not, literally, difcern objects that wore twenty yards difant from me.

\section{VAle of Cirucis.}

About ten miles from Ruthin I dcfcended into this, one of the molt charmingly fecluded vales that our kingdom can boan, furrounded by high mountains, 
tains, and abrupt rocks towering rudely into the fky. The bottoms of thefe were, in many places, clad with wood and verdure. In this vale are feated the venerable ruins of Llan Egweft, or Valle Crucis abbey; and from the road, at a little diftance, the fine gothic weft end, embowered in trecs, and backed by the mountain, on whofe fummit ftand the thattered remains of Caftell Dinas Brân, form a fcene finely picturefque. The adjacent precipices were enlivened by the browfing flocks, which were fcat-. tered along their fides, and by

\section{Kites that fwim fubline}

In ftill-repeated circles, fcreaming loud, whilf from below I was entertained with

The cheerful found

Of woodland harmony, that always fills

The merry vale between.

The rugged and woody banks of the Dee, upon my proceeding onward, foon added a frefh intereft to the fcenery of this beautiful retreat.-The vale extends nearly to Llangollen; and at the difance of about a mile, the town, with its church and antique bridge, romantically embofomed in mountains, whofe rugged fummits pierced the clouds, became additional features in the landfcape.

\section{Piliar of Eliseg.}

The vale of Crucis is indebted for its name to this crofs, or pillar, which is to be found in a meadow VOI.. II. 
near the abbey; and jun oppofite to the fe: in: mile-ftone from Llangollen *. This pillar is very ancient. It appears to have been erected upwards of a thoufand years ago, in memory of Elifeg (the father of Brochwel Yfcithroc, prince of Powis, who was flain at the battle of Chefter in 607), by Concenn, or Congen, his great grandfon. The infcription is not at prefent legiblet. The fhaft was once above twelve feet long, but having been thrown down and broken fome time during the civil wars, its upper part, only about feven feet in length, was loft. After thefe commotions it was fuffered to lie neglected for more than a century. At length, in 1779, Mr. Lloyd of Trevor Hall, the owner of the property on which it now fands, caufed this part of it to be railed from the rubbifh with which it was covered, and placed once again on its pedeftal.

\section{Valle Grucis AbBey,}

Or, as it is called by the Welin, Llan Egweft abbey, is about a quarter of a mile from the pillar of Elifeg. It is a grand and majeftic ruin, affording fome elegant fpecimens of the ancient gothic architecture.

* Buck fays the vale took its name from the circumftance of the aibley having poffeffed a piece of the true crofs. This, we are informed, was given to Edward I., who, in return for fo valuable a prefent, granted to the abbey-feveral immunities. Buck's Antiquities. Matt. Wefm. 37 r.

+ Mr. Edward Lhwyd copied it when it was in a more perfuct ftate. See Gough's Camden, ii. $58 z$. 
Mifs Seward has addreffed this abbey in language finely poetical and defcriptive:

Say ivy'd, Valle Crucis, time decay'd,

Dim on the brink of Deva's wandering flood,

Your riv'd arch glimmering thro' the tangled glade,

Your gay hills towering o'er your night of wood,

Decp in the vales's receffes as you ftand,

And defolately great the rifing figh command.

There are ftill remaining of the church the eaft and weft ends, and the fouth tranfept. In the weft end there is an arched door-way, that has been highly and very beautifuliy ornamented: over this, in a round arch, there have been three lancet windows; and above thefe a circular, or marigold one, with eight divifions. The eaft end, from its ftile of architecture, appears of higher antiquity than the other; and its three long, narrow, and pointed windows, give it a heavy appearance. The cloifter on the fouth fide, which a century ago was only a fhell, is now converted into a divelling-houfe, the refidence of the perfon who farms the adjacent land. Three rows of groined arches, on fingle round pillars, fupport the dormitory, which is now a loft for containing corn, approached by fteps from without. The floors are here fo thick, from their being arched beneath, that when the doors are fhut, and the threfhers are at work, even in that part directly over the prefent kitchen, they cannot be heard below.-Part of a chimney in one of the bed-chambers is a relic of a fepulchral monument.-The ornaments 
to the pillars and arches are of free-ftone, and many of them are perfectly frefh and beautiful. The area of the church is overgrown with tall afh-trees, which hide from the fight fome parts of the ruin, but contribute greatly to its picturefque beauty.

I doe love thele auncient ruynes,

We never tread upon them but we fet

Oure foote upon fome reverend hiftoric;

And queftionle fs here, in this open courte

(Which now lies naked to the injuries

Of ftormy weather) fome men lye interred

Who lov'd the church fo well and gave fo largely to't,

They thought it fhould have canopied their bones

Till dombesday: but all things have their cnd;

Churches and cities (which hare difeafes like to men)

Mutt havic like death that we have.

This fober thade

Lets fall a ferious gloom upon the mind

That checks but not appals. Such are the haunts

Religion loves, a meek and lumble maid,

Whofe tender eye bears not the blaze of day.

Valle Crucis was a houfe of Ciftertian monks, dedicated to the virgin mother. It was indebted for its foundation, about the year 1200 , to Madoc ap Griffith, a prince of Powis, who, after various fuccerfes, and acquiring much booty by the reduction and ruin of Englifh caftes, dedicated a portion of his plunder to the fervice of religion! He was interred here. At the diffolution the revenues appear to have amounted to about two hundred pounds per aninum*.

* Powel, 255.-293. Tamier. Yorke, 57. 
I thall conclude my account with a fingular paffage from Mr. Grofe's work on the Antiquities of Great Britain. It contains the explanation by Mr. Griffiths of the Navy Office, of an infcription found on the ruins, and is as good a fpecimen of antiquarian ipfe dixit as I have ever met with:

"Moft of thefe houfes were founded by an injunkion from the popes, by way of penance, upon fome great lords of thofe times, for what the holy church judged infringements on her prerogative; or for fome crime which thofe fathers of the church knew full well how to avail themfelves of.-- Taking the matter in this light, and from the Welf name of the place, the infcription upon the ruins will be intelligible. The characters are mafo-gothic, and franco-theotifan mixt.- -MD H OO HR BMSPOT, ac ha aPO u $\mathrm{S} \doteq \mathrm{PRO} B H Q V$ OES CM $\mathrm{C}$ RQO.-The firt double letters I take to be MAD, or Madocus; H. hoc; OO. monafterium; HR. honori; B. beate; M. Marix; S. fanctx; P. pœ-nitens; OE. Edificavit; ac, et; $h \Theta$. hoc; a P. appropriavit; Ou S. opus; PRO. pro; B. bono; HQV. hofpitioque; OES. ejufdem; CIM. centum marcas; GR. gratis; $Q$. quoque; O. ordinavit.In Englifh, Madoc, a penitent, erecled this monaftcry to the bonour of the bleffed and boly Virgin, and appropriated for this work, and for the better maintenance thereof, an bundred marks, withich be freely fettled on them!" 


\section{LLANGOLLEN.}

From thefe elegant and beautiful fcenes I wandered into the dirty, ill built, and difagreeable town of Llangollen. The ftreets are narrow, and all the houfes are built of the dark fhaly ftone fo common in North Wales. The fituation of this place is, however, truly delightful to the admirer of nature: it ftands on rocks that overlook the Dee, and is furrounded by high and bold mountains.

The bridge, which confifts of five narrow and pointed arches, was originally erected about the iniddle of the fourteenth century, by John Trevor, bifhop of St. Afaph. It is built on the rock, and in a place where it would almoft feem impoffible to fix a foundation fufficiently firm to withtand the furious rapidity of the current, which has worn the fhelving maffes to a black and gloffy polifh. During late years it has undergone confiderable repairs.

In the clutrch I found nothing deferving of attention. The name of the patron faint, who has left behind him a legend worthy even of the Koran, is pretty enough, and of no great length! Collen, ap Groynawe, ap Clydawe, ap Cozurda, ap Caradawe Freichpas, ap Llyr Meirim, ap Einion Urth, ap Cuneddu Wiedig*:-From the church-yard, the lofty mountains, on one of which ftands Caftell Dinas Brân, and the woody banks of the Dee, whofe

* Euniedd y Sainet. Welh Archeology, ii. 52. 
rapid Atream winds along the valley, form a fcene by no means inelegant.

\section{Plas NewYdD.}

About a quarter of a mile fouth of Llangollen is Plâs Newydd, the charming retreat of lady Eleanor Butler and Mifs Ponfonby, which, however, has of late years been probably too inuch intruded upon by the curiofity of the multitudes of tourits who every fummer vifit Llangollen. Lady Eleanor Butler was, I am informed, the youngeft fifter of the late, and is confequently aunt to the prefent earl of Ormond.-Mifs Ponfonby is the grand-daughter of general Ponfonby, who was flain in the battle of Fontenoy. Her father, Mr. Chambre Ponfonby, married Mifs Louifa Lyons, a moft elegant and accomplifhed woman, the fecond daughter of captain John Lyons, clerk of the council in Dublin. This lady lived but a few years after her marriage, and left the prefent Mifs Ponfonoy, her only child.Thefe two females, delighted with the fenery around Llangollen, when it was littlo known to the relt of the world, fought here a philofophical retirement from the frivolties of fafhionable life, crected a dwelling that commands a fine mountain profpect, and have refided here evex fince. 


\section{Castril. Dinas Bran}

Is fituated on a high, and fomewhat conical hill, about a mile from Llangollen. This hill is fo very ftcep on ail fides, towards the fummit, as to render the walk to the caftie not a little fatiguing.-'The building has been about a hundred yards long, and fifty in breadth; and it formerly occupied the whole crown of the mountain. From its extremely elevated fituation it muft have been a place of vaft Atrength. On the fide which is leaft fteep it was defended by trenches cut through the folid rock. The prefent remains confift of nothing more than a few thattered walls. The views from heice on every fide are very grand. Towards the eait I could look along the whole vale of Llangollen, through which the Dee was feen to foam over its bed of rocks; and, beyond the vale, I could fee all the flat and highly cultivated country that extended for many miles. Juft beneath me lay the town of Llangollen. 'Towards the wett I overlooked the vale of Crucis, and the mountains beyond it were all expofed, their dark fides agreeably varied with wood and meadow. On the north-iveft I was much ftruck with the fingular appearance of a vaft rock called Craig Eglwyfeg, The Eagle's Rock, from a tradition that formerly a pair of eagles had their neft, or aëry, here. Leland has miftaken this rock for that on which the caftle ftands, where he fays, "there bredith every yere an egle. And the egle doth forely 
forely affault hym that deftroyeth the neft; going downe in one bakket, and having another over his hedde, to defend the fore ftripes of the egle." For upwards of a mile this rock lies ftratum upon ftratum, in fuch a direction as to form a kind of horizontal fteps, denominated by naturalifts faxa fedilia.-The inhabitants of Llangollen affert, that in one part of the rock there is an opening, whence a long arched paffage leads to the foundation of the caftle. The latter part of this affertion is evidently falle from the fituation of the building; and I could fcarcely even credit the report of a cavern in the rock, for, though fuch is generally believed to exif, I was not able on frequent inquiry either to find any perfon who had himfelf feen it, nor could any one point out its fituation to enable me to examine it.

\section{History of Casteli Din.ls Bran.}

This fortrefs, from the ftile of its architecture, was evidently the work of the Britons. It is fuppofed by fome writers to have been founded by Brennus, the Gaulic general, who is reputed to have come into this country to contend with his brother Belinus. The fimilarity of names feems, however, the only foundation for the conjecture, and the mort accurate hiftorians believe it to have originated at a much later period.--The mountain river Brân runs at the foot of the hill, but whether the fortrefs derived its name froin the ftrean, or the Atream 
from the fortrefs, would be no eafy matter to decide at the prefent day: Mr. Edward Lhwyd, a juftly celebrated antiquary, who lived upwards of a cenltury ago, confiders the former to have been the cafe.

Caftell Dinas Brân was the principal refidence of the lords of Yale, and probably was founded by one of them.-In the reign of Henry III., Griffith ap Madoc refided here. He had married the daughter of James lord Audley, by which his affections were alienated from his own country; and he took part with the Englifh againft the Wellh prince. This induced a perfecution, which compelled him to feek for fecurity in this aërial retreat, and confine himfelf to the walls of his caftle. The Welfh writers fay that grief and hame, not long afterwards, put an end to his life *.-His fon poffeffed the property; and, after his death, the guardianfhip of his two children was given by Ed. ward I. to John earl of Warren, and Roger Mortimer. In the account of Holt caftle, I have ftated that the iniquitous guardians caufed the boys to be murdered, and then feized the eftates to their own ufe. Caftell Dinas Brân was part of Warren's thare in the plunder $t$.

In the ninth year of Edward II., the grandfon of the earl of Warren having no iffue, furrendered this and other fortrefies to the king. Being, how-

* Powel, 194, Pennant, i. 216. 297.

t Gibfon's Camden, 58:2. 
ever, afterwards feparated from his wife, he obtained a regrant of the eftates to himfelf, and his miftrefs, Matilda de Nereford, for life, with remainder to their children. Matilda was the laft furvivor, and therefore on her death, in the thirty-third year of Edward III., they reverted to the crown.-Not long afterwards they were given to Edward Fitz Alan, earl of Arundel; and from him they feem to have followed the fucceffion of the lords of Bromfield *.

In I 390, Caftell Dinas Brân was the habitation of Myfanwy Vechan, a very beautiful and accomplifhed female, a defcendant of the houfe of Tudor Trevor. She was beloved by Howel ap Einion Lygliw, a Welfh bard, who addreffed to her an ode full of fweetnefs and beautyt:

'Mid the gay towers on fteep Din's Branna's cone,

Her Huel's breatt the fair Mylanwy fires,

Oh! harp of Cambria, never hatt thou known

Notes more mellifuent floating o'er the wires,

Than when thy bard this brighter laura fung,

And with his ill-ttarr'd love Llangollen's echoes rung.

Thus confecrate to love in ages flown,

Long ages fled, Din's Branna's ruins thew,

Bleak as they ftand upon thcir fteepy cone,

The crown and contraft of the vale below,

That fcreen'd by mural rocks with pride difplays

Beauty's romantic pomp in every fylvan maze.

At what period this cante was demolifhed, we have no information. Churchyard, who vifited it

- See the account of Hult cafle. † Pennant, i. 298 : 
in the fixteenth century, calls it " an old and ruynous thing *."

\section{VALE of LLANGOLLEN.}

In order that I might fee the beauties of the vale of Llangollen to as great an advantage as poffible, I determined to walk round it. 'This led me through a circuit of about eleven miles. - I croffed Llangollen. bridge, and went along the road leading to Ruabon and Wrexham, on the north fide of the river. The Tcenery in this direction was pretty, but from the lownefs of the road it had nothing particularly interefting. The moft beautiful profpects were thofe that I had by looking back towards the town. In thefe the caftle, from its great elevation, formed a very confpicuous feature; and in many places the Dee added confiderable beauty to the fcene.-I pafied. Trevor Hall, the family feat of the Lloyds, feated on an eminence above the road.

I had proceeded fomewhat more than four miles when I turned to the right, along a road which led over the Dee at Pont y Cyffyllte. Near this bridge I faw the columns of the famous aqueduct formed for conveying the water over the river Dee and the vale of Llangollen. At the time I was here there were eleven erected: they were of ftone, and fquare, and the two that ftood in the bed of the river were each about a hundred and twenty feet high. From a tablet on cne of them I copied the following in-

* Worthines of Wales, 127 .

fcription, 
fcription, which will fufficiently explain the nature of the undertaking:

The Noblity and Gentry of

the adjacent counties

having united, their efforts with

the great commercial intereft of this country; in creating an intercourfe and union, between

England and North Wales,

by a navigable communication of the three rivers,

Severn, Dee, and Merfey,

for the mutual benefit of agriculture and trade,

caufed the firtt ftone of this aqueduct of

$$
\text { Pont Cyfyllty, }
$$

to be laid, on the $25^{\text {th }}$ day of July, MDCCxCr.

when Richard Middleton of Chirk, Efquire, M.. one of the original patrons of the

Ellefmere Canal,

was Lord of this manor,

and in the reign of our fovereign

GEORGE THE THIRD,

when the equity of the laws and

the fecurity of property,

promoted the general welfare of the nation,

while the arts and fciences flourihed

by his patronage, and

the conduct of civil life, was improved

by his example.

1 returned to Llangollen by the Ofweftry road on the fouth fide of the river. This is confiderably elevated above the bottom of the vale, and from hence all the furrounding objects are feen to great advantage. From thefe fteep banks the Dce's tranfparent ftream is feen to wind in elegant curves, along 
the wooded meadows beneath. The mountains on the oppofite fide of the vale are finely varied in thape and tints; and Trevor Hall, feated on its eminence, embofomed in woods, lent its aid to decorate the fcene. From hence Caftell Dinas Brân, and its conical hill, feem to clofe up the end of the vale, and imperioufly to hold in fubjection all the furrounding country. This fylvan vale, juftly celebrated for its numerous beauties, affords many picturefque and highly romantic fcenes.

The Hand is the only tolerably good inn in Llan. gollen, but in fummer I have more than once found it very unpleafant, from the crowd of travellers that are confantly paffing on the great roads to and from Ireland, and from the number of Welih tourifts that vifit Llangollen. I never yet heard any one fay that he received either civility, or good accommodation, at this houfe: I have often heard, and I have experienced the contrary. 


\section{G H A P. XIX. \\ Llancollen to Corwen.}

The Vale of the Dee.-Llandyryilo Hall.-Extenfive Profjecti-

Menoranda of Owen Glyndwur. - Corwen. - Church. - Fisure, que Scene.-Cefyn Creini.-Excurfion to Glynn Bridge.

$A_{L L}$ the country betwixt Llangollen and Corwen is exceedingly beautiful. The road, for about a mile, extends along the picturefque vale of Crucis, which, through its whole length, is adorned with woods, and in many places enlivened by neat little cottages peeping from among the trees.-I had not paffed this vale far before I entered the valley of the $D_{\ell \varepsilon}$, Glyn Dyfrdwy, celebrated as, fome centuries ago, the property of the Wellh hero, Owen Giyndwr. The mountains are high, and their features bold and prominent. From the winding of the river, and the turnings of the vale, almoft every ftep prefented a new landfcape.

I paffed Llandyfilio halli the family feat of the Jones's, feated on a woody flat, near the oppofite edge of the Dee. From its fituation in the bofom. of the mountains, it is fecluded from the world, but there is fo much elegance around it, that it appeared to me a charming retreat. - This Tyfilio, to whom the 
the parifh church is dedicated, and from whom the hall takes its name, was a Wellh faint, and held in fuch veneration, that no fewer than fix churches have been dedicated to him. He was the fon of a prince of Powis, and the writer of the molt ancient hiftory of Britain now extant.

Looking back upon the country I had left, I faw Caftell Dinas Brân, and its accompanying rock, Craig Eglwyfeg, at the head of the vale. The latter forms from hence a very confpicuous object.

About half a mile beyond Llandyfilio, I clambered to the top of a lofty hill on the left of the road. I was confiderably deceived in its height. I fancied that it extended no higher than the ridge vifible from the road; but I had no fooner attained this, than I had another eminence before me: I perfevered, and found two others equally high beyond this.

From the fummit of this eminence I had a view of the whole wle and its various windings, with its ftill more ferpentizing river, immediately beneath me. Caftell Dinas Brân was very evidently lower than my prefent ftation. I could carry my eye along the entire vale of Llangollen, and over the flat country for many miles beyond, to the far diftant mountains on the verge of the horizon.

I defcended to the road, and continued my journey.-Beyond the fourth mile-ftone, the vale began 
to change its appearance. The road, inftead of winding amongft mountains, now lay in a direct line.

About three miles farther on, an oak wood on the left, and a fmall clump of firs on an eminence on the right of the road, mark the place near which the palace of " the wild and irregular" Owen Glyndwr once ftood. There are at prefent no other remains of it than a few fcattered heaps of ftones. Iolo Goch, Owen's bard, about the year i 390 , wrote a poem containing a defcription of this palace. He fays it was furrounded by a moat filled with water, and that the entrance was by a coftly gate over a bridge. The ftile feems to have been of gothic architecture, for he compares one of the towers to a part of Weftininfter abbey. It was a Neapolitan building, containing eighteen aparments, "a fair timber fructure, on the fummit of a green hill."

\section{Memoranda of OWen Glyindwr.}

This celebrated hero, whofe actions make fo confpicuous a figure in the Englifh hiftory at the commencement of the fifteenth century, was the fon of Grifith Vychan, a defcendant of Meredith, prince of North Wales. He received a liberal education; and when of proper age, was admitted a ftudent in one of our inns of court, and was afterwards regularly called to the bar. It is probable that he foon quitted the profeffion of the law, and adopted that of arms, which, as it afterwards proved, was much 
more congenial with his difpofition. He warmly efpoufed the caufe of Richard II., to whom he was fincerely attached. He adhered to his royal mater till the laft, having been taken prifoner with him in Flint caftle; and when the king's houfehold was diffolved, retired to his patrimony in Wales, with full refentment of his fovereign's wrongs. It appears that during the reign of Richard II. he had received the honour of knighthood, for in a legal procefs of that period, he is filed fir Owen de Glendore.

He niarried a daughter of fir David Hanmer, of Hanmer in Flinthire, one of the juftices of the court of King's Bench; and had by her fiveral children.

In'the beginning of the reign of Henry IV. Reginald lord Grey, of Ruthin, taking advantage of the depofal of Richard, and Glyndwr's attachment to his caufe, wrefted from him a confiderable part of his poffefions. Glyndwr applied to the parliament for reỏreis, but in vain. His ambitious fpirit, confpiring with a ferfe of his wrongs, and a deteftation for the ufurper Bolingbroke, determined him to throw off, if poffible, the Englifh yoke, and to obtain by force the government of Wales. He revolved in his mind his ow gुenealogy, a defcendant from the ancient Britif princes: his fuperftitious notions attached to himfelf many of the prophefies of Merlin, and other bards of former years. Thefe, with the dreadful omens that he believed had taken place at his birth, onnfrmed him in the opinion that he was deftined 
to be the redeemer of his country from the tyranny and oppreffion of the Englifh throne. Shakfpere puts a finely defcriptive fpeech into the character of Glyndwr:

\section{At my birth}

The frorit of heaven was full of fiery thapes;

The goats ran from the monntains, and the herds,

Were ftrangely clamorous to the frighted fields:

Thefe figns have marked me extraordinary,

And all the colirfes of my life do thew,

I am not in the roll of common men.

He firt appeared in arms in the year 1400 ; and commenced his warlike career, by attacking his chief enemy, lord Grey. He was fo far fuccefsful as to take this nobleman prifoner; and he compelled him to marry one of his daughters. By this fuccefs his eftates were recovered. Glyndwr now meditated, and foon afterwards performed more extenfive exploits. Aided by the inacceffible mountains of Wales, and foldiers on whofe valour he had the utmoft reliance, he fet at defiance the whole power of England. After a feries of engagements which lafted more than twelve years, he proved himfelf fo formidable an enemy to Henry IV. that at length the Englifh monarch thought it politic to make him an offer of accommodation. Death, however, prevented him from accepting it.. He died in September I415, as it is fuppofed, at the houfe of one of his daughters at Monnington in Herefordlhire; and he probably was buried at that place, but there is 
no memorial whatever of the fpot where his body was depofited.

Superftition feems to have been a reigning folly with Glyndwr during the whole of his life. This, together with his own wonderful exploits, and the defire of infufing terror into the minds of his foes, feems to have been the caufe of his declaring himfelf klilled in magic.

Where is he living-clipp'd in with the fea,

That chiles the banks of England, Scutland, Wales,

Which calls me pupil, or has read to me?

And bring him out that is but woman's fon,

Can tracc me in the tediuus ways of att,

Or hold me pace in deep experiments. -

I can call fpirits from the va?ty decp.

In his general character, Glyndwr appears to have been bold, fpirited, and ambitious; but, from his frong and unaffected attachment to the unfortunate Richard, every one muft efteem him as having been a faichful friend, who had dared to follow his mafter's fortunes to the laft. His fpirit of revenge led him too often to acts of cruelty towards his captured enemies, and even towards thofe of his countrymen who did not thew themfelves active in his caufe. His chief bard, Griffith Llwyd, fpeaks in high terms of his valour:

Loud fame has told thy gallant deeds,

In every word a Saxon bleeds,

'Terror and flight together came,

Obedient to thy mighty name:

Death 
Death in the van with ample ftride, Hewed thee a paffage decp and wile;

Stubborn as fteel thy nervous cheit

A more than mortal's ftrength pofiefs'd.

The monkifh writers, all of whom were under the influence of his enemies, affert, that Glyndw ended his days in the utmoft mifery: that, outcalt from fociety, he wandered from place to place, difguifed in the garb of a fhepherd, and in a moft low and abject condition: that he was forced to fhelter himfelf even in caverns and defert places from the fury of his enemies. But it is evident that if his fituation had been thus deplorable, the Englifh monarch would never have condefcended to propofe terms to fuch a fcourge as Glyndwr had proved himfelf to his kingdom. - The Welth chieftain died unfubdued *.

For two miles before I arrived at Corwen the vale had completely changed its afpect. It was here deftitute of wood, and the low and verdant mountains were cultivated nearly to their fummits. The river Dee had affumed a placid form, and glided filently and fmoothly within its flat and meadowy banks.

* Mr. Pennant, in his Tour in North Wales, p. 32.5-392, has given a very long and detailed account of the actions of this celebrated character. From this account, corroborated by the old hiftorians, the preceding character has been principally drawn. 


\section{CORWEN,}

The Wbite Cboir, is a difagreeable little town, with a white-wafhed church. Its fituation is under a rock at the foot of the Berwyn mountains. - It is a place much reforted to by anglers, who come here for the advantage of fifhing in the Dee, which abounds in falmon, trout, and variaus other fpecies of efcuculent fifh.

The church contains an ancient monument to the memory of Iorwerth Sulien, one of the vicars: In the church-yard there is an apparently very old fquare ftone pillar, that has once had much carved work upon it, but from the effects of time and weather, this is now nearly obliterated.-There is alfo, joinirig upon the church-yard, an alms-houfe, founded in 1709 by William Eyton, efq. of Plàs Warren, in Shrophire, for the ufe of fix clergy, men's widows of Merionethfhire.

A mill on a fream at the back of the inn I found a picturefque object; and fome of the cottages near it are rude, and fingularly built. The young artift would find here a good ftudy or two.

Corwen is celebrated as having been a place of rendezvous to the Wellih forces under their prince Owen Gwynedd; who from hence, in I 165 , put an end to the invafion of Henry II. *

* Cam, Reg. i. 192. 


\section{Cefyn Creini.}

Near the fummit of a hill on the oppofite fide of the river, called Cefyn Creini, The Mountain of Worthip, there is a valt circle of loofe Itones, which bears the appearance of having once been a Brition fortification. This is called Caer Drewyn and $Y$ Caer Wen, The White Fort. It is near half a mile in circumference, but the walls are at prefent in fuch a ftate, that at a diftance they appear like huge heaps of ftones piled round the circumference of a circle. Owen Gwynedd is believed to have occupied this poit, whilt Henry II. had his men encamped among the Berwyn mountains, on the oppofite fide of the vale. It is alfo related that Owen Glyndwr made ufe of this place in his occafional retreats.- The whole circle is perfectly vifible from the road leading to Llanrwht, at the diftance of about two miles from the town.

\section{Griyn Bridge.}

From Corwen I made an excurfion of fix miles to Pont y Glynn, The Bridge of the Glen, on the road leading to Llanrwft. The fcenery along the whole walk had numerous beauties; but from one fituation I had an uncommonly fine view along the beautiful vale of Edeirnion, bounded by the lofty Berwyn mountains, and adorned with the moft pleafing cultivation.The woody glen, at the head of which ftands Pont 
y Glynn, with its prominent rocks, nearly obfcured by the furrounding foliage, after a while prefented itfelf; and then, almoft in a moment, on a fudden turn of the road, appeared the bridge, thrown over the chafm. Beneath it was the rugged and precipitous bed of the river, where, amongft immenfe maffes and huge fragments of rock, the ftream foamed with the moft violent impetuoufity. The tranfition to this romantic fcene was fo monentary, as to feem almoft the effect of magic. The cataract is not very lofty, but from its being directly under the bridge, where the foam and fpray was feen dafhing among the dark oppofing rocks, and having the addition of pendant foliage from each fide, a fcene was formed altogether finely picturefque and elegant. The bridge refts on two nearly perpendicular rocks, and appears to be at leaft fifty fect above the bed of the ftream. - The view from thence down the hollow was grand and tremendous. 


\section{$(185)$}

\section{G HAP. YX.}

CORWEN TO BALA.

The Vale of Edeirnion. -T he Waterfall at Cynzuyd.-Llanderfol. - Account of the Image of Derfel Gadarn, and the Superfitions of the Welj People.-Execution of Friar Foreft, and the fingular Completion of a Propliefy. - Memoranda of the Welph Bard Llywarcb Hên.-Bala.-Bala Lake.-Account of a Fỉh called Gruyniadd found bere.-Dreadful Overflowings. - Excurfion round the Lake. - The Phenomenon called by the Welfb Dear-dor.-An Adventure of Two Gentlemen at Llanwchllyn. - Cafell Corndochon.-Caer Gai.-The River Dee.

THE diftance from Corwen to Bala, along the ufual road, is about eleven miles; but as there was another that for fome miles accompanied the Dee, I was induced to prefer it. This road, as I had imagined from my map, extended along the vale of Edeirnion, which I had fo much admired in my late ramble to Glynn Bridge. I found it fo bad, as in fome places to be nearly impaffable. From its very low fituation I had few opportunities of feeing the elegancies of the vale; but whenever the road paffed over an eminence, I found much to admire. 


\section{Waterfall of Cynwyd.}

At the village of Cynwyd, The Source of Mifclief, (probably fo called in confequence of the courts which formerly were held there by the great men of the neighbourhood, to fettle the boundaries of the adjacent commons, and to take cognizance of encroachments*,) I left the road about half a mile, and proceeded along a deep glen that led me to Rhaiadr Cynwyd, The Waterfall of Cynwyd. The water dafhed from precipice to precipice, among the wood and rocks, in the wildeft and moft romantic manner imaginable. The fcene was fo varied from the confufion of the water foaming in every direction, and partly hidden by the fhrubs and trees growing on the ledges of the rocks, that the pen cannot defcribe it with juftice, and even the efforts of the pencil could only give a faint conception of its elegance. Many detached parts of it afford excellent ftudies to the admirers of picturefque beauty.

I refumed my journey, paffed Llandrillo, The Church of St. Trillo; and afterwards croffing the river, arrived at Llanderfol, another fmall village, whofe church is dedicated to a Britifh faint, called

\section{* Pennant, ii. 72 .}

DERFEL 
Derfel Gadarn.

The church once contained a vaft wooden image of this, its patron faint, which was formerly held in fuch fuperftitious veneration, that people from very diftant parts made pilgrimages to it, and on thefe occafions offered not only money, but fometimes even horfes or cattle. The Welfh people believed that Derfel Gadarn had the power of once reicuing each of his votaries from the torments of hell. On the $5^{\text {th }}$ of April I 537, the fentival day of this faint, no fewer than betwixt five and fix hundred perfons, fome of them from a great difance, came to Llanderfel to make the accuftomed offerings.-The letter from Elis Price, commiffary-general of the diocefe of St. Afaph, to Cromwell the vicar-general, of which the following is a copy, was the firt caufe of this very lucrative antique being deftroyed, to the great difpleafure, no doubt, of the monks, who rioted in the produce of its coffers:

" Right honorable, and my fyugular good lorde and mayfter, all circuminanncys and thankes fett afide pleafithe yt yowre good lordefhipe to be aduifid that where I was conftitute and made by yowre honorable defire and commaundmente comiffarie gencrall of the dyofefe of Saynte Afaph, I liaue done my diligens and dutie for the expulfinge and takynge awaye of certen abufions fuperfticions and ipocry fes ufid withyn the faide dy ofefe of Saynte Affaph accordynge to the kynges honorable rules and injunctions therein made, that notwithittandinge, there ys an image of Darvell Gadarn withyn the faide diofefe in whom the people have fo greate confidence lope and trufte that they come daylye a pill. 
gramage unto hym forne withe kynr, other withe oxen or horfis, and the refle withe money in fo muche that there was fyve or fyse hundrcthe pillgrames to a mans eftimacon that offered to the faide image the fifte daie of this preferte monethe of Apll; the innocente people hathe ben fore aluryd and cntifid to worhipe the faicle image in fo muche that there is a comyn faynge as yet amongit them that who fo ever will offer anie thinge to the faice image of Darvell Gadarn, he hathe power to fatche hym or them that fo offers once oute of hell when they be dampned. Therfore for the reformacon and amendmentc of the premifis I wolde gladlie knowe by this berer youre honorable pleafure and will, as knowithe God; who euer preferme your lordefhipe longe in welth and honor. -Written in Northe Walcs the vi. day of this prefente Aprill (1537).-Youre bedeman and dayelic orator by dutie.

$$
\text { "ELIS Price*." }
$$

The Welfh people had extant a prophefy concerning this image, that it hould "make a foreft blaze," and in the enfuing year an opportunity occurred not only of depriving them of the caufe of their fuperfition, but even of completing the pro. phefy, in a manner, however, that they little expected. A friar obfervant, whole name was Foref, was condemned to the ftake for having denied the fupremacy of the king $t$. The name was thought by the heads of the church a fortunate occurrence, and it was advifed that the image fhould be imme-

* Cotton MSS. in the Brition Mifeum; Cleoratra. E. IV. fol. 55 .

+ On his araignment Foreft replied to the court, in anfwer to the proof of perjury againit him, in having before taken the oath: "I took the oath with ny ouiwerd man, but my inward man never confented to it." Holin/hed, ii, 945. 
Jiately brought to London to confume this wretched friar. To the ftake on which he fuffered was affixed the following elegy:

David Dariel Gatheren,

As fayth the Wellhmen,

Fetched outlawes out of hell.

Now is he come, with fpere and fhield,

In harncs, to burne in Smithfield,

For in Wales he may not dwell.

And Foreft the friar,

That obftinate lyar,

That wilfully nall be dead,

In his contumaciè,

The gofpel dothe deny

And the king to be fupreme head*.

At Llanfawr, The Great Village, two miles from Bala, is the fuppofed place of interment of

\section{The Welsh Bard, Llywarch Hen,}

Who flourifhed in the feventh century. He was nearly allied to the Welfh princes, and to his bardic character united that of a warrior. His whole life was fpent in a feries of vicifitudes and misfortunes, and 'he died about the year 670 , at the great age of a hundred and fifty years. Somewhat more than a century ago an infcription was found upon the wall, near which his remains were fuppofed to have been depofited: this wall is now covered with plafter.-Not far from hence there is a circle of ftones

* Halle's Chroricle, ccxxxiii.

called 
called Pabell Llywarch Hên, The Tent of old Llyzuarch, where it is probable he had a houfe, and fpent the latter part of his days. He had been one of king Arthur's generals, and a member of his council. In his activity in oppofing the encroachments of the Saxons and Irifh, he was deprived of his whole patrimonial poffeffions, and loft every one of his four-and-twenty fons. Having now no friends, he retired to a hut at Aber Cuog (now Dôlguog, near Machynlleth,) to foothe with his harp the remembrance of misfortune, and to vent in elegiac numbers the forrows of old age in diftrefs. One of his poems, particularly, defcribes his misfortunes, and his deplorable fituation, in the moft fimple and affecting language. It opens with the reprefentation of an aged prince, who once ruled in 'magnificence, now robbed of his poffeftions, and wandering in a ftrange country, oppreffed with wretchednefs and poverty. Overcome with fatigue and hunger, he is fuppofed to reft his wearied limbs on the top of an eminence, and to contemplate there the varied and unhappy events of his life. This elegy has appeared in an Englifh drefs: what follows is a felection from it, as the whole would be too long for infertion here:

Hark! the cuckoo's plaintive note

Doth thro' the wild vale fadly float ;

As, from the rav'nous hawk's purfuit,

In Cing refts her weary foot;

And there, with mournful founds and low,

Echoes my harp's refponfive woe. 
Returning fpring, like opening day,

That makes all wature glad and gay,

Prepare's Andate's fiery car,

To roufe the brethren of the war;

When as the youthful hero's breatt

Gloweth for the glorious teft,

Rufhing down the rocky ftecp,

See the Cambrian legions fweep,

Like meteors on the boundlefs deep.

Old Mona fmiles

Monarch of an hundred ifles.

And Snowdon from his awful height,

His hoar head waves propitious to the fight.

But I - no more in youthful pride,

Can dare the fteep rock's haughty fide ;

For fell difeafe my finews rends,

My arm unnerves, my ftout heart bends ;

And raven locks, now filver-grey,

Keep ine from the field away.

But fee!-He comes, all drench'd in blood,

Grven, the Great, and Gwên, the Good;

Braver, noble a, worthieft fon,

Rich with many a conqueft won;

Gwên, in thine anger great,

Strong thine arm, thy frown like fate;

Where the mighty rivers end,

And their courfe to ocean bend,

There, with the eagle's rapid flight,

How wouldt thou brave the thickeft fight !

Oh, fatal day! Ol, ruthlefs deed!

When the fifters cut thy thread.

Ceafe, ye waves, your troubied roar;

Nor flow, ye mighty rivers more;

For Gwîn, the Great, and Gruen, the Good,

Breathlefs lies, and drench'd in blood! 
Four and twice ten fons were mine, Us'd in battle's front to fhine; But_low in dutt my fons are laid, Nor one remains his fire to aid.

Hold, oh hold, my brain, thy feat ;

How doth my bofom's monarch beat!

Ceale thy throbs, perturbed lieart;

Whither would thy thetchld ttrings ftart?

From frenzy dire, and wild affright,

Kecp my ferfes thio' this uight*

\section{BALA,}

'The' Outlct of the Lake, is a market town containing about two thoufand inhabitants. It confifts principaily of one long and wide ftreet, and is fituated at the bottom of a pool, the largeft in the country, called Llyn Tegid, The Fair Pool. It is principally noted for its manufacture of woollen ftockings, and as the autumnal refort of grous hooters. Lord Lyttleton afferts its celebrity for the beauty of its women, and that he faw fome of the prettielt girls here that he ever beheld.

Near the town I paffed a lofty artificial mount called Tommen y Bala, The Tumulus of Bala. This. is fuppofed to have been of Roman origin, and to have been formed here, with a fmall caftle on its fummit, to fecure the pafs towards the fea, and to keep the mountaineers in fubjection. The Wellh

* See the preface to Owen's tranflation of the Elegies of Llywarch Hên. Jones's Welfi Bards. Vaughan's Merioneth. fhire. Camb. Reg. i. 192. 
taking advantage of it, made it one of their chain of fortreffes which extended through the country to the coaft of Flinthire.-The hiftory both of this place and of the town is little known. I only find that the mount was fortified in the year 1202 by Llewelyn ap Iorwerth, prince of North Wales.On the eaftern bank of the Dee, not far diftant, there is another mount called Caftell Gronw Befro Benllyn, The Caftle of Gronw the Fair, of Penllyn, a Wellh chieftain who lived in the fixth century*.

\section{BaLA LaKe,}

Llyn Tegid, or Pimblemere, for this pool has thefe various names, is about a quarter of a mile fouth of the town of Bala. It is by much the largeft of the Wellh lakes, being about four miles long, and in many parts near a mile in breadth. 'The fcenery around it is mountainous, but not fufficiently rude to render it very picturefque. It reminded me of the low mountain-fcenery furrounding Winandermere, in the north of England. From the bottom, however, the diverfified fhores prefent to the eye a pleafing fcene. On the weft are feen the fummits of the lofty Arrenigs. Arran Benllyn, beyond the upper end of the pool, ftretches his black and rocky front into the clouds; and in the extreme difance, in fainter colours, are feen the three fummits of Cader Idris.

- Powel, 258. Pennant, ii. 77.80. Cam. Reg.i. Igr.

VOL. II.

This 
This pool is well ftocked with fifh of various kinds, but in particular with trout, eels, and a fpecies found only in alpine lakes, called, from the whitenefs of its fcales, Groyniadd. It is a gregarious fifh, the Salmo lavaretus of Linnæus. Its greateft weight feldom exceeds three or four pounds. With refpect to the tafte, this fith is generally faid to be infipid: the noble traveller quoted in a preceding page, afferts, however, that it is fo delicate, that his friend would prefer the flavour of it to even the lips of the fair maids of Bala. The time of fpawning is in the month of December. Thefe fifh ufually keep at the bottom of the water, where they feed on finall fhells and aquatic plants.-It is generally believed by the inhabitants of the neighbourhood, that atthough the Dee runs directly through this' pool, the gwyniadds are never to be caught in the river; nor, on the contrary, are the falmon with which the river abounds, ever taken in the pool. Hence Churchyard;

A poole there is thro' which the Dee doth paffe,

Where is a fin that fome a whiting call:

Where never yet no falmon taken was,

Yet hath good ftore of othe: fifnes all.

A bove that poole, and fo bencath that flood

Are falmons caught, and many a fin full good, Hut in the fame there will no falmon bee,

And neere that poole you fhall no whiting fee.

This is a fingular circumftance, but there appears fome truth in it. The honourable Daines Barrington, 
ton, who made many inquiries refpecting it, obferves to the affertion, that they never' encroach upon each other; that he had feen a falmon caught in the lake more than two hundred yards from the bridge, and that he had been authentically informed of feveral of the gwyniadds having been caught in the Dee near Llandrillo, eirght miles from Bala *.-The fifhery of Bala lake is the property of fir Watkin Williams Wynne.

The overflowings of this pool are at times very dreadful. Thefe, however, feldom take place, except when the winds, rufhing from the hollows of the mountains at the upper end, drive the waters fuddenly along. In ftormy weather great part of the vale of Edeirnion will fometimes be overflowed. By the united force of the winds and mountain torrents, the water towards the bottom of the pool has been known to rife fix or eight feet in perpendicular height. On the contrary, in calm and fettled weather, it is always very imooth. There have been fome inftances, in fevere winters, of its being entirely frozen over; and when covered with fnow, it has been miftaken by travellers for an extenfive plain.

Excursion round Bala Lake.

In this excurfion, of about ten miles, I croffed the bridge over the Dee, and proceeded along the

* Phil. Tranf. for 1767 . 
eaftern bank of the pool. From near the church of Llangower, a pleafing vale was feen to open on the oppofite fide, bounded by mountains, and clofed at the end by one of the Arrenigs.

I had paffed the head of the pool fomewhat morethan half a mile, when I found the narrow lane which leads to Llanwchllyn, The Church above the Lake. I left the road, and foon afterwards entered the Vale of Twrch. Nature is feen in all her majelty here; but as lord Lyttleton obferved of the Berwyn. mountains, "it is the majefty of a tyrant frowning over the ruins and defolation of a country." There were no marks of habitations or culture; and heath, mofs, lichens, and a few grafes, feemed the only vegetation. The furrounding mountains were as rude as defcription can paint: the moft prominent of thefe was Arran BenHyn, which here prefented: only a feries of naked crags and precipices.-From hence I croffed the river Twrch, Thc Burrower *.

\section{Phenomenon Chleed Daear-Dor.}

- My guide now pointed out a piece of land, of confiderable extent, nearly covered with innumerable mafles of broken rocks. Thefe, he faid, had all been conveyed thither in the fummer of $178 \mathrm{I}$, by what the inhabitants of the mountains call Daear-

* The Welh word́ Twrch fignifies a bog : this river, therca fore, feems to derive its name from its fometimes impetuoufly tumbling along the ftones or earth that oppofe its progrefs.

Ders 
Dor, a breaking of the earth. The daear-dor is a diflodgement, by means of water, of a vait quantity of the furface of the ground, or, as in the prefent inftance, of a conficierable part of fome of the rocks among the higher mountains. An unufual volume of water defcending fuddenly from the clouds becomes lodged in fome confined fituation: by degrees it penetrates the earth, and this loofering, the whole mafs is fwept along before the torrent, till it meets with refiftance in fome of the vales below, where it is therefore depofited. The accident near Llanwchllyn happened after a violent ftorm of thunder. The banks of the Twrch were overflowed, and the torzent carried every thing before it that was not actually embeổded in the rock. Seventeen cotiages, ten cows, and a valt number of fheep, befides the foil of all the meadows and corn-fields along its courfe, were overwhelmed and deftroyed. This meadow, in which the river depofited its chief contents, was rendered totally unfit to be any more cultivated. The dimenfions of fome of the pieces of rock borne here by the fury of the torrent, are almof inconceivable. Two of the fones came in contact, which were each near twenty feet long, eight broad, and fix deep, and by the collifion one of them was fplit. Eight other fones, about half this fize, were carried near nine hundred yards beyond. Five bridges were fwept away; and had not the inhabitants of Llanwchllyn, providentially, reseived timely alam, every one of them would have 
been deftroyed. The only perfon miffing was a poor old woman, who was confined to her bed by ficknefs *.

Whilf fpeaking of the neighbourhood of Llanwchllyn, I muft digrefs a little from my fubject to relate a whimfical adventure which happened to a gentleman of my acquaintance, Mr. D., an artift, and his friend, whilft at this village a few fummers ago.Thefe gentlemen, in a pedeftrian excurfion round Bala lake, found themfelves, on their arrival at Ilanwchllyr, fatigued and hungry. As neither of them could fpeak a word of Welih, they were compeiled to have recourfe to figns in order to make themfelves underftood. Thefe fo far anfwered their purpofe, that a man whom they met in the village exclaimed in anfwer, "eze" (intended doubtlefs for "ycs"), and pointed with his finger to a kind of hut, from the rafters of which two or three dirty candles, and a few bits of bacon were fufpended. On entering they again made the figns of eating and drinking, and the woman, though beyond meafure aitonifhed at their manners and appearance, had fenfe enough to condust them to what they conjectured to be the public-houfe. Here their attention was fixed upon fome fragments of bacon, which had hung fo long, that all the ftrings had nearly cut their way through. They explained by figns, as well as they were able, what it was they wanted, and the

- Pennant, ii. 8 . 
female of the houfe brought out tbree eggs. This was a flender fupply for two hungry men. They both called out "more," the woman anfwered " eze," but brought out the frying-pan. They thook their heads, fhe fetched a fauce-pan. Here they found a difficulty that they knew not how to encounter. A bright thought fuddenly came into the other gentleman's head:- " D., you can draw, afe the woman for a piece of cbalk, and draw an egg." The abfurdity of the idea was fuch, that Mr. D. could not refrain from a loud and hearty laugh. It was, however, at laft agreed, that the woman fhould be fuffered to boil the three eggs, but that when the brought them to the table, D. was to fnatch them from her, and pretend to eat them all himfelf. The plan fucceeded; the woman laughed immoderately at the conteft, and running out with a cry of " eze, eze, eze," foon afterwards brought in four eggs more. There was no difficulty in making the payment for this rude cheer: $\mathrm{Mr}, \mathrm{D}$. held out fome filver in his hand, from which the honeft Welfnwoman took eighteen pence for the feven egrs, and a quart of ale!

On the fummit of a high and craggy rock, at fome difance from the road, and about a mile from Llanwchllyn, are the remains of Caftell Corndocbon, an ancient Britifn fort. It was of a fomewhat oval form, and has confinted of a fquare tower, and another oblong, but rounded at the extremity. I

04

have 
have met with no hiftorical data whatever refpecting this fortre's.

In my return I obferved an eminence on the weft fide of the head of the pool, which the guide informed me was called Casr Gai. There was on this fpot a fort that belonged to Cai Hir ap Cynyr, or, as Spencer has called him, 'Timon: he was the folter-father of king A.rthur, who during his youth refided here. The Romans are fuppofed to have had a fortrefs on this fpot; and many of their coins have been dug up in the neighbourhood*. This place of defence was doubtlefs conftructed to guard the pafs through the mountains. Of its hiftory I am altogether ignorant.

\section{The River. Dee.}

The fource of the Dee is under one fide of $\mathrm{Ar}$. ran Benllyn, the high mountain at the head of Bala pool.-Its name is thought to have been derived from the Welfh word Dwy, which fignifies fomething divine. Some centuries ago it was held in fuperftitious veneration by the inhabitants of the country, from what were then believed the miraculous overflowing of its banks at times when there had been no preceding heavy rain: and from its being believed to have foretold fome remarkable events by changing its channel t: Hiftory informs

* See Spencer's Faerie Queene, book i. canto ix., and Camb, Reg. i. Igr.

+ Giraldus Cambremis, lib. ii. c. iis. 
us, that when the Britons, drawn up in battle array on its banks, have been prepared to engage with their Saxon foes, it was their cuftom firft to kifs the earth, and then for every foldier to drink a fmall quantity of the water *-The name is certainly not derived, as many have fuppofed, from Dû, black; for, except when tinged by the torrents from the mountain moraffes, its waters are perfectly bright and tranfparent. In Spencer's defcription of Caer Gai, the dwelling of old Timon, the forter-father of Arthur, the colour of the Dee is confidered very different from black:

-Lowe in a valley green,

Under the foot of Rawran, moffe o'er,

From whence the river Dee, as fllver clene,

His tumbling billows rolls with gentle roar.

That lover of the marvellous, Giraldus Cambrenfis, informs us very gravely, that the river Dee runs through Bala lake, and is difcharged at the bridge near the town, without their waters becoming mixed. He doubtlefs means to fay that the river might be traced by its appearance from one end of the lake to the other. Giraldus believed every thing that the inhabitants chofe to impofe upon him.

* Gibfon's Camden, 556. 


\section{H A P. XXI.}

\section{BALA TO SHREWSBURY.}

Cafcade at Pont Cynzuyd.-Rbizuedog. - Trûm y Sarn. - The Bersuyn Mountains. - Llangynog. - Slate Q Quarries. - Hazardous Made of conveying Slates from the Mountain into the Vale. - Lead Mines. - Llanrbuiadr. - The Cataract of Piflyll Rbaiadr. - The $V$ ale of Langedzuin. - Knockin. - Account of the fingular D:foowery of a Murderer. - Kynafion's Cave in Nefs Cliff.-Moniford Britge. - Shrezufbury.

Leaving Bala, I turned my fteps towards England, and occupied two days in the journey from hence to Shrewbury. Thefe, from fevere rain that fet in when I had got about ten miles from Bala, and lafted with little intermiffion till I arrived at Shrewfbury, were rendered two of the mont unpleafant days I had fpent in the country.-At my outfet the morning was, however, very ferene. The fun, in exhaling the dews, gave a delightful air of frefnnefs to all the furrounding objects. The whole fcene was enlivened by the mufic of the birds, whofe various tones and elegant ftrains would have interefted lefs ardent admirers of the works of nature than myfelf. Every thing feemed to partake of a general fprightiness. The thrilling tones of the ky-lark were heard on every fide: the notes of the blackbird choed from anong the diftant foliage, 
Whilt now and then fweet Philomel would wail, Or ftock-doves plain, amid the foreft deep, That drowfy rufted to the fighing gale; And ftill a coil the grafs-hopper did keep.

Thefe rural objects continued, however, for very few miles; for I then entered on a fucceffion of dreary and open moors, which might have charms for the fportfman, but they had none for me.

About a mile and a half from Bala, I paffed a bridge called Pont Cynzuyd. The bed of the turbulent little ftream is here crowded with huge maffes of rock, deeply excavated into circular hollows by the furious eddying of the water. In one fituation theie rocks, with the ftream rufhing down amongf them, form a fmall but pleafing cafcade.

A little beyond the bridge ftands Rhiwedog, $T$ be abrupt Afcent. This was an ancient family feat; and a vale in its neighbourhood was the fcene of that fevere battle betwixt the Britifh and Saxon forces, in which the aged Llywarch took an active part, and loft his only furviving fon.

From the fide of a fteep, on the edge of the moors, I was prefented with a diftant view of the vale of Edeirnion, whofe verdure and fertility formed a f triking contraft with my bleak and dreary fituation. - The road now led me over Trûm y Sarn, The Caufeway of the Ridge, a place that has its name from being near a lofty heath-clad mountain, which I paffed at a little diftance towards the fouth. It is 
one of that immenfe range of mountains which ex. tend fifteen or fixteen miles, and are called Berwyn Mountains. 'The two molt elevated fummits are Cader Ferwyn, and Cader Fronwen.-I arived at a noted bwlch, or pafs, which divides the counties of Merioneth and Montgomery, called Milltir Gerig, The Stony Mile.

\section{LLANGYNOG.}

I had now a view into the curious and romantic sale of Llangynog, a hollow fo completely inclofed on all fides by inountain barriers, as apparently to afford no outlet to the refidents in its bofom. The mountains feemed in many places nearly perpendicular, and their cliffs too fteep to be fealed by any other than thofe moft active of all Britin animals, the fheep and goats. Thefe I obferved browfing along the fides with the utmoft unconcern. The bottom was entirely in a ftate of cultivation, but principally as meadow land: it was interfperfed with the houfes of the farmers and their labourers.

A tolerably good road took me from the edge of this vale, by a defcent, fomewhat fteep, firt into the hollow, and then to the fmall and comfortlefs village of Llangynog, The Church of St. Cunog.

\section{Slate Quarries.}

From a ftupencous rock, which rifes on the north fide of the village, are obtained thofe flates for which 
this neighbourhood is celebrated through all the adjacent counties *. The quarries are fituated high up in the mountain. I obferved that the mode of conveying them to the vale was different from that practifed near Llanberis, which I have already defcribed, but it appeared much more dangerous. The flates are loaded on fmall fledges, which are to be conveyed down the fide of the mountain, along winding paths formed for the purpofe. Each of thefe fledges has a rope by which it is faftened to the fhoulders of a man who has the care of conveying it. He lays frrm hold with his hands, and thus, with his face towards it, begins to defcend. The velocity which the fledge acquires in its defcent is counteracted by the man's ftriking forcibly againft the prominences with his feet. This manœuvre, fince he goes backward, and has at the fame time fome attention to pay to the fledge to keep it in the track, muft be difficult to attain, and long practice alone can render it eafy. The danger to an obferver feems very great: on inquiry at the village, I was, how ever, informed that a ferious accident had fcarcely ever been known to occur from it.

* Betwixt November 1775 and November 1776 , upwards of 904,000 nates were fent from hence at different rates of betwixt fix thillings and twenty hillings per thonfand. Pennant, ii. 347 . 


\section{LEAD Mines:}

At Craig y Mwyn, about two mifes and a half from Llargynog, fomewhat more than a century ago, a vein of lead ore was difcovered, fo valuable as to yield to the Powis family, for forty years, a clear revenue of at leaft twenty thoufand pounds a year. It had been worked to the depth of about a hundred yards, when on a fudden the water broke in, and became fo powerful, that the proprietor was cempelled to abandon the undertaking *. Ever fince that time the mines have continued nearly filled with water, but fome gentlemen a few years ago determined to attempt their recovery, and for this purpofe levels were to be driven in various parts of the mountain, if poffible, to drain off the water. Whether they have proceeded in the attempt, or given it up, I have not the means of being informed. -Befides thefe there are fome mines, but of lefs importance, near the village, which were worked when I was at Llangynog. The produce of thefe $\dot{I}$ was informed was very trifing.

On my leaving Llangynog, the clouds gathered round the fummits and fides of the mountains, and the rain foon afterwards began to defcend in tor: rents. This village appeared, however, fo wretched a place for a wearied traveller, that I had no in- 
ducement to return for thelter. In the greateft misfortunes we are generally able to find fome object on which we can reft with fatisfaction: it foon occurred to me that the drenching of my clothes would be amply compenfated by the increafed volume of water at the cataract of $P$ iftyll Rhaiadr, which I intended to vifit in the morning. The idea of this gave me fo much pleafure, that when I became fairly wet to the $\mathrm{kin}$, I was altogether carelefs as to perfonal comfort; and now the fafter and more heavily the rain defcended, the better a great deal I was pleafed with it.

\section{LIANRHAIADR.}

In this ftate it was that, after about two hours flippery walking, and my clothes dripping with wet, I arrived at Llanrhaiadr, The Village of the Cataract, fituated, like Llangynog, in a deep hollow, furrounded on all fides by mountains, whofe fummits were now entirely obfcured by clouds. This hollow is called Mochnant, The Vale of the rapid Brook. The houfes, or rather cottages, of the village are irregular; but, as moft of them were old and overgrown with vegetation, it had from many points of view an appearance highly picturefque.

I found very tolerable accommodations, even for the night, at the Coach and Horfes, an inn, or rather public-houfe, whofe exterior does not befpeak the good opinion of the traveller. 
Dr. William Morgan, who firft tranflated the Bible into the Welfh language, was vicar of this place. He was afterwards rewarded with the hithopric of Llandaff, and in $160 \mathrm{I}$ with that of St. Afaph.

\section{Pistyll Rhaiadr,}

The Spout of the Cataract, the moft celebrated waterfall of this country, rufhes down the front of an almoft perpendicular rock, that terminates a vale at the diftance of about four miles from the village. The vale is narrow and well wooded; it is watered by the little river Rhaiadr, which here conftitutes the boundary line betwixt the counties of Denbigh and Montgomery, and it affords many pleafing and beautiful fcenes. The upper part of the cataract, when the fun fhines upon it, is vifible to a great diftance; and along this hollow its filvery and linear appearance give an air of fingularity to many of the views.-Pifyll Rhaiadr is upwards of two hundred and ten feet high; and for near two thirds of this height, the water is thrown down the flat face of a bleak, naked, and barren rock ; from thence it rages through a natural arch, and betwixt two prominent fides into the fmall bafon at its foot. The whole fcene is deftitute of wood, but it has fo much fimple grandeur, that trees would injure, rather than heighten the general effect. When vifited after very heavy rain, a fingular occurrence is to be remarked. The water in its defcent is obftructed by 
the mals of rock, through which it feems by time to have forced a paffage, and it is faid to burit through it with a vaft quantity of fpray, appearing like frioke from the explofion of a cannon.-I was told that the late worthy vicar of Llanrhaiadr, Dr. Worthington, with a view of gratifying the curious, had a pair of flood-gates fixed on the ftream, above the cataract, occafionally to obftruct the paflage of the water: when a fufficient quantity had been collected behind them, they were fuddenly thrown open, and the rufhing down of the flood is faid to have afforded one of the grandef fpectacles imaginable.-This gentleman alfo erected a fmall building, at the foot of the rock for the accommodation of vifitors, which is found very convenient to thofe who bring refrefhments along with them.

On my return from the cataract, I left Llanrhaiadr, and proceeded along the road which leads through part of the vale of Llanisedwen. I paffed Llangedwên hall, a handfome ftone edifice, the property of fir Watkin Williams Wynne. This place was a favourite refidence of the late baronet, but it is feldom vifited by the prefent owner.

I now arrived once again at Llanymynech. Betwixt this village and Shrew bury I had fo much rain, as to render the journey in every refpect dreary and uncomfortable. 'Through the thicknefs of the mift I could but juft difcern the Breiddin Hills, at the diftance of a few miles on the right : their funmits were perfectly obfcured in clouds.

$$
\text { YOI. II. }
$$

KNO: 


\section{KNOCHIN,}

A village about five miles from Llanymynech, has once been a place of fome celebrity. The hall was the refidence of the family of L'Eftrange, who built the town. They had on its fite a caftellated manfion fo early as in the reign of Henry II. The laft of the family was Joan, who married George Stanley, the cldeft fon of the firft earl of Derby. The following occurrence is faid to have taken place, fome years ago, in the neighbourhood of Knochin:

A man of the name of Elkes was left guardian to his brother's fon. This boy was very young, and the only obftacle to Elkes becoming poffeffed of confiderable property. He had long revolved in his mind the manner in which he could rid himfelf of this incumbrance, and at length hit upon the following inhuman expedient: a poor child of the village was directed to take the boy to a diftant corn-field to play and gather flowers. Elkes met them near the fpot, and directed the other child to return immediately home. He then took his ward up in his arms, walked with him to the end of the field, where he knew there was a tub nearly full of water, and forcing his head into it, held him in that pofition till the child was fuffocated. The neighbours foon obferved that the boy was miffing; the poor boy who had accompanied him to the field told his fimple ftory, and a party of them, on fearching the place, difcovered the body. Informa- 
tion foon reached them that Elkes had fled towards London. Two horfemen were therefore immediately dilpatched in purfuit of him. Thefe men were riding along the road near South Mims in Hertford. thire, when they were furprized by the fingular actions of two ravens, that were perched on a cock of hay in an adjoining field. The birds made an unufual noife, and furiouly pulled about the hay with their beaks. Curiofity alone, the men faid, induced them to alight, and fee what could be the caufe of fuch fingular actions. They threw down the heap of hay, and were aftonifhed to difcover beneath it the man of whom they were in fearch. He afferted that, thefe two birds had followed him inceffantly, from the time that the murder had been committed. This unhappy victim of avarice was conveyed to Shrewfbury, tried, condemned, and afterwards hùng in chains on Knochin heath *

\section{Kynaston's Cave,}

A few miles from Knochin I paffed under a high rock of red free-ftone, called Nefs Cliff. In the fouth-eaft fide of this rock there is a cave, which has the name of Kynafton's Cave. This was a place of occafional retreat to Humphrey, the fon of fir Roger Kynafton, conftable of Harlech caftle, and a party of his mad companions. He was outlawed in the fixth year of the reign of Henry $\mathrm{VII}_{2}$, was

* Plillips's Hittory of Shrew Bbury. A pp. 233 . 
pardoned in the year following, and died in 1534. $\mathrm{He}$ is remembered by many ftrange pranks, and ftill continues the talk of the neighbouring peafantry.

Leaving this rock, I foon afterwards faw, by the road-fide, a fmall building, from which feveral boys were coming. An infcription over the door arrefted my fteps for a moment:

God profper long this public grood, A fchool ereeted, where a chapel food.

In what this originated I did not learn.

I croffed the Severn at Montford bridge; and in about an hour afterwards ended my pedeftrian excurfion at Shrewtbury. A defcription of this town will occupy the enfuing chapter. 


\section{(213)}

\section{H A P. XXII。}

SHREWSBURY.

Shrewjbury Cafle. - Walls. - County Gaol. - Bridges. - Shrewfbury Albey.-Ancient Oratory.-St. Giles's Church.-St. Alkmund's Church.-Daring Feats on the Point of the spire.A Singular traditional Story.-St. Mary's Church.-Account of a Man killed in fiding down a Rope from the Spire, to a Field, acrofs the River.-St. Fulian's Church. - Old St. Chad's.-New St. Chad's.-The Quarry. - Account of the Houfe of Induftry.The Ruins of the Three Friaries.-Public Buildings. - Hifory of Shrewfoury. - Lift of remarkable Events.

SHREwsBury is a town of confiderable magnitude and importance, fituated on a floping ground, and nearly furrounded by the Severn. The ftreets are irregular, and many of the buildings very ancient. -This place once formed the capital of Powilland, and was for fome years a feat of the Wellh princes.

\section{Ciastle.}

In my tour through the town and fuburbs I firft: vifited the caftle. This is built of a red ftone, and fituated on an eminence above the river, juit in that part of the town where the river leaves it undefended. Its foundation has been afcribed to Roger de Montgomery, the great earl of Shrewlbury, who 
lived in the reign of William the Conqueror, but of the ancient ftructure there is not at this time much remaining. It is the property, and forms one of the refidences of fir William Pulteney, in right of his Iady, Henrietta, baronefs of Bath. 'The owner, however, very feldom vifits the place.-The kecp ftood on a large artificial mount, which feems to prove it of Saxon or Britih origin.

'The caftle continued in poffeffion of the two fons of the founder till the reign of Henry I., when that monarch chofe to take it into his own hands. After the reftoration of Charles II. it was granted to Francis, lord Newport, afterwards earl of Bradford; and fome time confequent to this grant it became the propsuty of the Pulteney fanily.

\section{WALLS.}

Robert de Belefme, fon to Roger de Montgomery, was the firlt who attempted to defend the town by walls. This he did, by building from the caftle down each fide of the river for a confiderable diftance; and thus he fecured himfelf for a while from the attacks of his enemy, Henry I. The remaining part of the walls was erected in the reign of Henry III., at the requeft of the inhabitants, to fortify the place againft the inroads of the Welfh. So great, however, was the want of money for the completion of the undertaking, that thirty-two years elapfed, before they could be finifned.-A very fmall portion of the walls is now left. From one fituation near 
them I had a good profpect of part of the fuburbs of the town.

\section{County Gaol.}

At a little diftance beyond the caftle, and, like that building, on the elevated bank of the Dee, I faw the county gaol, a large and handfome ftructure. It is built of brick, and in a fituation that cannot be furpaffed for the purity, and confequent healthinefs, of its atmofphere. In a niche over the entrance there is a buft of Howard. The outer walls were begun in the year 1789 , and fome of the apartments were ready for the reception of prifoners in 1796 , but the building is fcarcely yet finifhed.

I proceeded along a pleafant terrace walk to the end of the building, whence defcending to the river, I found a foot-path which led me to the Englifh bridge. From hence the caftle, the river, and the town, partly hidden by trees, with the fpires of St. Mary's and St. Alkmund's churches, formed a beau. tiful and pieturefque fcene.

\section{The Stone Bridge, 。}

Called alfo the Eaft bridge, the Englifh bridge, and the New bridge, is an elegant ftructure, of feven arches, which was 'built about thirty years ago.Near the middle of it are the water-works, from which the town receives its fupply of that very effential article of life.-On the weft fide of the 
town, in a direction nearly oppofite to this, is the other, called the Welfh bridge. This is a late erection. The ancient bridge had a gate, and towers at cach end, a necefiary defence againt the turbulent neighbours on that fide of the water.

\section{Shrewsbury ABbey}

Is fituated in the fuburbs of the town, a little beyond the ftone bridge. The prefent remains confift of only the weft part, from the crofs ifle to the wert tower. The choir, the cloifter, and chapter-houfe, are entirely deftroyed. Of the fide inles, the arches are yet left, and the eaft end of the prefent church is a modern wall that has been run up betwixt two of the ancient columns. It is fuppofed to have been made parochial; and to have received this addition in the reign of queen Elizabeth. The great towver is fill left, and contains a fine gothic vindow, over which is a ftatue, fuppofed to reprefent the founder, Roger de Montgomery. The whole building is of the fame kind of red ftone as the caftle, and, except the weat window, is in the Norman gothic file of archtecture, with plain arches, and maffy columns.- On the fouth fide of the altar there is a recumbent figure, in a coat of mail, and in the act of drawing a fword, which is believed to have been the monument of ITontgomery - An infcription intimates that it was difcovered among the ruins of the abbey, and that, in 1622, it had been directed 
directed by the heralds at arms to be carefully preferved, in confequence of which it was placed in its prefent fituation.

The hiftory of the abbey is fhort. It was founded by Roger de Montgomery, and his countefs Adeliffa, in the year 1083 , and dedicated to St. Peter and St. Paul. Its monks were of the Benedictine order, and firft brought over from Seez, in Normandy; and the earl, by permifition of his lady, became himfelf one of the religious of his own abbey. He endowed it largely, and encouraged all who were dependant on him to become benefactors. At his death, about nine years afterwards, he received here an honourable interment.-Robert, the fourth abbot, procured, though with much difficulty, the bones of St. Wenefred, and had them enfhrined here.-The property of the abbey at the diffolution was valued by Speed at about five hundred pounds per annum.-On the church being made parochial by queen Elizabeth, it received the name of St. Crux, or the Holy Cross, in the abbey of Shrewbury, which name it ftill retains.

In the garden of fir Charles Oakely, - on the fouth fide of the church, is a fmall, but elegant octagonal building, the remains of an ancieni oratory, belonging to the abbey, now called St. Wenefred's Pulpit.

Churches. 


\section{Churches.}

The remaining clurches in Shrewfbury are,

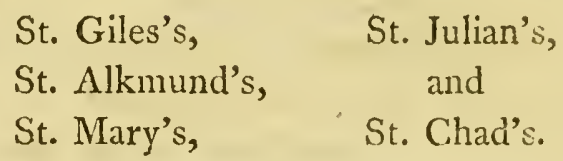

St. Criles's cburch is fituated on the flirt of the fuburbs, about a mile eaft of the abbey. It is an ancient, finall, and inelegant, but fomewhat picturefque building. It boafts a higher origin than the abbey, and in domefday book is called "the parifh of the city." It is at prefent annexed to the church of Holy Crofs, or the abbey. The bones of St. Wenefred, when they were removed from Denbighthire to Shrewfbury, are faid to have been firt, for a time, depofited in this church.--In the churchyard, but now almoft obliterated, is an inicription to the memory of William White, a quarter-mafter of horfe, in the reign of William III.:

In Irifh wars I fought for England's glory;

Let no man fcoff at telling of this ftory.

I faw great Schomberg fall, likewife the brave St. Ruth, And here I come to die, not there in my youth.

'Through dangers great I have pafs'd many a ftorm,

Die we all muft, as fure as we are born.

St. Alkmund's clourch is remarkable for its handfome fpire. It contains an eaft window of ftained glafs, the workmanthip of Eginton of Birmingham. This was put un in the year 1795 , and, as I was informed, 
informed, coft about two hundred pounds. Its execution was infinitely fuperior to any thing that I had before feen in glass. A figure reprefenting Faith is in the attitude of kneeling on a crofs. Her arms are extended towards a crown, which appears from the clouds; and the countenance bears an interefting expreftion of mingled adoration and wifdom. "Be thou faithful unto death, and I will give thee a crown of life," is the motto. The lights appeared to me well difpofed, and the drapery good. The colours are fo managed as to prevent any glaring effect from the pallage of light through a tranfparent medium; a fault too ofien obfervable in paintings on glafs.

This church is faid to have been founded by the heroine Ellleda, the daughter of king Alfred. The body of the building is modern, but the tower and fpire appear of confiderable antiquity.

In the year 1621 , about four yards of the top of the fpire were taken down, and rebuilt by a man of the name of Archer, who came from St. Alban's. His fool-hardy feats are yet in the mouths of the inhabitants. On Saturday, the $22 \mathrm{~d}$ of February, he climbed up the outfide of the fpire to the top, and brought down the weather-cock, notwithftanding its fize and weight were fuch that he could with difficulty holi it. On the $3 \mathrm{~d}$ of March he climbed up again, and put the weather-cock in its former place, turning it about feveral times, ftanding upright on the iron crofs, and fhaking both his hands and legs. In the 
following week he climbed up, taking with him a drum, and a long bow and arrows. He ftood upright on the closs, beat the drum, and hhot an arrow from the bow. On the $13^{\text {th }}$ of March he again went up, and turned the weather-cock round like a wheel: he fhook about his hands and legs, and continued hallowing and fnouling there for more than two hours. In every one of thefe daring exploits the man was in a ftate of intoxication.

If we may believe a manufcript written by the reverend Dr. Taylor, and depofited in the Free School library, the devil appeared in St. Alkmund's church in the year 1533 , as the prieft was at high mafs. . During a great tempon and darknefs he paffed through the cliurch, mounted up the fteeple, and, tearing away the wires of the clock, left the print of his claws on the fourth bell; and in his way out took off one of the pinnacles! This is a fingular mode of accounting for a violent thunderftom, and it will appear the more fingular when the reader is informed, that the prince of darknefs on this occafion appeared clad in the habit of a grey friar!

St. Mincy's cluturlb bears the apparance of great antiquity. The fouth and went entrances are beneath arches of Norinan arechitecture. This church was founded by king Eign! and it formerly had a dean and feven prebenciariss. Before the foundation of the abbey, it was efteemed the principal church in the town. It is a donative, and in the nomi- 
nomination of the mayor, and the head mafter of the Free School.

From the elevated fituation of the building, and the great height of its fpire, the latter has frequently fuffered from high winds. In 1739, the weather-cock was blown on one fide, when a perfon of the name of Cadman engaged to take it down, which he foon afterwards did, and then put it in its place again. This man was an adventurer on church fteeples of a different defcription from the man I have juft mentioned. He fixed a rope from the top of the fpire to a tree in a field on the oppofite fide of the river, and to various other places; and for a few times lided from thence without injury: but on Candlemas day in the fame year, after beating a drum, firing piftols, \&c. he attempted to flide down the rope acrofs the river, but it broke foon after he had trufted his weight upon it, and he was confequently dafhed to pieces.-He was buried on the fame day, the $2 \mathrm{~d}$ of February I739, at the foot of the fteeple, and a plain flab was fixed to the wall over his grave, with this quaint infcription, now fcarcely legible:

Let this fmall monument record the name Of Cadman, and to future times proclaim How by'n attempt to fly from this high fpire, Acrofs the Sabrine ftream, he did acquire His fatal end. 'Twas not for want of Akill, Or courage to perform the tafk, he fell, No, no, a faulty cord, being drawn too tight, Hurried his foul on high to take her flight, Which bid the body, here beneath, good night. 
St. Julan's church. The body of this building is of brick, and the tower of ftone; the former is of modcrn erection. When or by whom the church was founded is not known: it was formerly ftiled a Royal Chapel.

St. Chad's cluturch has very Iately been erected, at fome diftance from the ancient building of the fame name. Of the latter, part of the chancel is yet fanding, and is kept in repair as a chapel to the burying-ground. - This building (old St. Chad's) - Atood on the fite of a palace of the princes of Powis, which was deftroyed by fire during the Saxon wars. The church was probably erected not long afterwards. In the year 1393, the firft ftructure was burnt down by the careleffnefs of one of the workmen who was mending the leads. The fellow obferving the mifchief he had done, and that the flames had become too powerful for him to extinguifh them, ran home, put fome money in his pocket, and atteinpted to efcape, but was drowned in fording the river. On an inquifition before the coroners of the town of Shrewflury, the jury found, "That John Plomer, working upon the leads of St. Chad's church, and perceiving the fame in flames through his neglect, ran to his own houfe in the High ftreet, put five marks, four fhillings and fix-pence in his pocket, and fled; a when he came to the ford at the Stone Gate, endeavouring to make his efcape, he was drowned in the river Severn".-In order that this lofs might be retrieved, king Richard II. granted to the bailiffs and conmonalty of the town, for three 
years then following; a quittance from their feefarm, and likewife from their arrears of taxes then lately granted by the parliament to the king. The fabric erected from this indulgence is that of which the ruins are ftill left.

The Nerv St. Chads is built near the ground called the Quarry. It is highly ornamented. The principal entrance is through the weft door, into a circular veftibule that contains the ftairs leading to the galleries. The body of the church is circular, and in its appearance rather like a place of amufement, than a temple of God. The blue and white rails in front of the galleries, remind us too much of theatrical decoration. The fupporting pillars both above and below are out of all proportion. The upper ones are in the Corinthian order, and though the intention may have been to give an ap. pearance of lightnefs to the building, they are inexcufably too long for their diameter: one cannot always fhut out an odd affociation of ideas, and thefe columns, the moment I entered the church, reminded me of a range of long mould candles. The columns that fupport the galleries are of a different order, and, I prefume, by way of contraft, are as fhort and thick as the others are long and fmall. In addition, their bafes are made level with the tops of the pews, giving an appearance of want of fecurity. and firmnefs to the galleries. Thefe pillars correfpond exceedingly ill with the other parts of the building. All circular churches muft alfo reft under one very material 
material inconvenience; they are all, it is true, well calculated for fecing, but the articulation of the minifter, which ought to be the principal object attended to, is, in buildings of this nature, generally deftroyed by the reverberation of found.-I fhail add a fimple memorandum, which I found in the journal of an artift, whofe judgment even the architect of this church would fcarcely choofe to queftion: "In Shrewbury there are five churches, one of which, St. Chad's, is new, and, if the expreflion may be ufed, is a complete picture of deformity."

\section{The Quarry.}

From this building I defcended immediately to the Quarry, a molt delightful walk, along an avenue of limes, which led me to the Severn, and then a confiderable difance each way along its bank. The trees are large and old, and even in the hotteft days of fummer afford a fheltered and pleafant retreat. The ground is the property of the corporation; the part appropriated to paiturage is let to the irlhabitants, and the profits are ciffributed among the burgeffes.

\section{Tie House of INDUSTRY}

Is the fine brick building which is feen from hence on the oppofite lofty lank of the Severn. I croffed the river by the ferry with one of the directors, and was fhewn every thing within it that I vas defrous of feeing: 
The erection of this elegant ftructure was begun in the year 1760 , for the purpofe of receiving part of the foundlings from the great hofpital in London. Thefe were to be put out to nurfe in the country; and when of proper age were to be brought into the houfe, and inftructed in fewing, knitting, carding, fpinning, \&xc. till they were old cnough to be put out apprentices. The hofpital in London difcontinued fending children, and in confequence the building became ufelefs as to its original purpofe.The expences of its eredion amounted to more than twelve thoufand pounds. - It was afterwards made a place of confinement for prifoners of war.

An act of parliament was obtained by the inhabitants of Shrewibury to enable them to form a houfe of induftry for the poor of their feveral parifhes, and this building was purchafed and opened for the reception of its objects in December 1783 . The buildings, neceffary alterations, furniture, \&cc. coft feven thoufand pounds.

The inhabitants of thefe parifhes that are rated and affeffed, and poffeffed of property to the amount of thirty pounds per annum, or that are rated at fifteen pounds, are incorporated as grardians of the poor. From thefe there are chofen twelve directors, each of whom ferves his office for three years; and to the board of directors the management of the whole bufinefs of the houfe is entrufted. They meet, in a room appropriated to their ufe, twice a wcek.

VOL. II,

The 
The number of men, women, and children in the houfe when I was there, amounted to about four bundred. Their employment confifts principally in preparing their own clothing, which they do from the raw material to its finifhed ftate. The neceffary machines and implements are arranged in different apartments; and perfons verfed in fcribbling, carding, and fpinning wool, are cmployed to infruct the paupers. Weavers were likewife engaged, and a fhop was allotted for their accommodation. Work. ing rooms are alfo fet apart for hoemakers, taylors, \&ic. where the paupers who have been brought up in thefe occupations are employed, and where one divifion of the boys are taught to work. The largent apartments are allotted to the carding and fpinning rooms. The girls are by rotation employed and infructed, as much as pofíble, in cooking, managing the affairs of the kitchen and laundry, and in wafhing, fcouring, and fuch other work as may beft qualify them for fervice.-The ufual hours of working are from fix o'clock in the morning to fix in the evening, from the $\mathrm{r}$ ft of March to the middle of October; and from feven in the morning to fuch an hour at night as the directors choofe to appoint during the remainder of the year. They are al. lowed half an hour at breakfaft, and an hour at dinner. No work is done on Sundays; Saturday afternoons, from four o'clock ; Good Friday; Chriftmas day, and the two following days; Monday and T́uefday 
Tuefday in Eafter and Whitfun weeks; and on Shrew bury-fhow day.

To encourage the exertions of the poor, the directors make them an allowance of a fixth part of their earnings, as a gratuity; and this meafure has been crowned with the happient fuccefs. Twopence out of every fhilling that they hare earned during the week is paid to them at the end of it : this reward, whilft it has been found fieficient to ftimulate their endeavours, has not been fo abundant as to prociuce, however laid out, any bad effect. The working children have the fame proportion of allowance from their labours as the adults: but the fteward takes care of this little property, and keeps an account with each child, fubject to the infpection of the dircctors; he allows them what he thinks prudent to expend, and the reft is fuffered to accumulate. When it amounts to a fum fufficient for the purpofe, the girls generally petition to have it expended in a Sunday's drefs of a quality fuperior to the uniform of the houfe. The favings, of the boys are ufually referved till they are bound apprentice, when thefe are laid out in whatever may be of ufe to them in their refpective fituations.

The punifhments of the idle and refractory are inflicted in various ways. For fmaller offences they are clothed in fackcloth, have a clog faftened to them, or are deprived of the above gratuity. For more flagrant mifconduct they are confined to a cell where they are kept apart from all the reft, and 
fed only with bread and water. If they are mutinous, and endeavour to excite a fpirit of fedition among their companions, they undergo corporal punifhment. 'The latter has, however, been very feldom found neceffary; but, whenever it is inflicted, it is done in the prefence of all the perfons of the houfe, and, as might naturally be expected, has never failed to produce a very ftriking and ufeful effect.

During the fummer months the paripers rife at hali-paft fire, and in winter the prayers and breakfaft are over before the break of day.-The fires and candles are extinguifhed in the cvenings at nine o'clock from the ift of May to the ift of September, and at eight during the reft of the year.-There are ftated hours for naking the beds, cleaning the dormitories, wafhing and combing the children, \&c. by which means a conftant attention to that cleanlinefs is kept up which fo greatly excites the attention of every ftranger, and ftrongly recommends the exa cellence of the inftitution.-The whole family breakfaft, dine, and fup together in the dining-hall : they are claffed feparately, the men, the women, the boys, and the girls at their refpective tables.

A general bill of fare is appointed, fo that the provifion for each day is prepared without any pere plexity or confufion: 
BREAKFAST.

Dinner.

Supper.

\begin{tabular}{|c|c|c|c|}
\hline Eunday. & Broth. & $\{$ Butcher's meat, and $\}$ & Broth. \\
\hline londay. & $\begin{array}{l}\text { Mill-por- } \\
\text { ridge. }\end{array}$ & Bread and cheefe. & $\begin{array}{l}\text { Marhed } \\
\text { potatoes. }\end{array}$ \\
\hline uefday. & $\begin{array}{l}\text { Milk-por- } \\
\text { ridge. }\end{array}$ & $\begin{array}{l}\text { Stewed meat, with } 1 \\
\text { tatocs, or orher g } \\
\text { den-1tuff. }\end{array}$ & $\begin{array}{l}\text { Peafe } \\
\text { foup. }\end{array}$ \\
\hline ednefday. & $\begin{array}{l}\text { Milk-por- } \\
\text { ridge. }\end{array}$ & $\left\{\begin{array}{c}\text { Peafe-pudding, an } \\
\text { ftewed pork. }\end{array}\right.$ & Broth. \\
\hline hurfday. & Broth. & $\left\{\begin{array}{l}\text { Butcher's meat, } \\
\text { gaiden-fuff. }\end{array}\right.$ & Broth. \\
\hline iday. & $\begin{array}{l}\text { Milk-par- } \\
\text { ridge. }\end{array}$ & $\left.\begin{array}{l}\text { Yeaft dumping, or hot } \\
\text { cake, (a pound for an } \\
\text { adult, childrenin pro- } \\
\text { portion) and milk. }\end{array}\right\}$ & $\begin{array}{l}\text { Mahed } \\
\text { potatoes. }\end{array}$ \\
\hline $\mathrm{y}$. & $\begin{array}{l}\text { Milk por- } \\
\text { ridge. }\end{array}$ & $\begin{array}{l}\text { Stewed meat, with po- } \\
\text { tatoes, or other gar- } \\
\text { den-ftuff. }\end{array}$ & Broth. \\
\hline
\end{tabular}

The quantity allowed for breakfaft is a pint either of broth or milk-porridge to each adult; and to the children in proportion.-For dimer, the grown up perfons have nine ounces of meat, fix ounces of bread, a trencher full of roots or greens, and a pint of beer. Working boys and firls have each five ounces of meat, four ounces of bread, with roots or greens, and half a pint of beer. The children drink water.-At fupper the adults are allowed a pint of broth or foup, and nine ounces of bread; and the children in proportion. The other fuppers confift of a trencher full of potatoss mahed with milk, and a pint of beer.-As it would create an endlefs trouble to weigh out every feparate $\mathrm{mefs}$, when one has been weighed, the reft are afcertained by the bulk. 
The perfons who manage thefe and all the other immediate concarns of the houic, are a fteward and matron, who are anfwerable for their conduct to the board of lirectors.

At a little difance fiom the houfe there are two ranges of builuing that run parallel with each other. The one contains apartments to which the poor are fent, on their adnifion, to be ftripped and wathed; and, if found to have any cutaneous, or other infectious diforder, they remain there till they are cured: there are, of courfe, feparate wards for the women and the men. Adjoining to this there is an apartment to which the dead are immediately conveyed, to remain till their interment. In the fame range is another apartment, called the Fever Room. In the oppofite range is the houfe infirmary, with feparate wards for the men and women; where the fick and infirm are lodged under the care of nurfes, and attended by the apothecary of the houfe. In furgical cafes, the patients are generally fent to the county infirmary.

The chaplain reads morning and evening prayers in the chapel every day, when all the paupers, both men, women, and children, attend; and on Sunday aftemoons he reads prayers and preaches.

The advantages of this inftitution became apparent in a very fhort time after it was commenced. Notwithfanding the heavy experices neceffarily attending an eftablifment of this nature, the inhabitants of the different parifies found that even durirg 
the firft year, the fum required for the maintenance of the poor was near two thoufand pounds lefs than the fum raifed for that purpofe in the preceding year: and they now derive a moft important pecuniary advantage from this eftablifhment. The aged and infirm are comfortably provided for, and the young are trained in habits of indufery and virtue. A complete ftop has been put to the great frauds and abufes that prevailed in the parochial expenditure; and even thofe poor who have laboured under temporary diftrefs or difability, have been more liberally affifted and relieved in their oron druellings, than had before been found practicable. Thus, while the poor have derived thefe important benefits from the inftitution, the inhabitants have alfo been greatly relieved in their parochial taxes. The amount of the reduction in the term of twelve years was very near twenty thoufand pounds.

But a fill greater advantage is derived to fociety in general, and to the immediate objects in particular, by the feeds of virtue and haprinefs that are carefully fown in the minds of the younger branches of this little community. Children thrown upon the parifh from their birth are put out to nurfe, where they remain till they are of age fufficient to be admitted into the houfe. The nurfes are occafionally required to bring them before the directors, that thefe niay obferve that care is taken of them, and that the children may be identified, and thofe frauds guarded againft which have not unfrequently 
been practifed. When taken into the houfe, the chiluren are put under the care of the houfe nurfes, the boys in one nurfery, and the girls in another. As foon as they are capable, they every morning and afternoon attend the fchool-room, where proper inftructors are provided. Here they are taught to read. Soon after they are five years old they are taken into the factory, or fpinning-room, and begin to fpin yam at the long wheel, under the tuition of a fpinning mitrefs; and then they attend the evening fchool, after the working hours are over.-They amufe themfelves after their meals, and at fome other times, in a large piece of ground behind the houfe, and inclofed by a funk fence. By habit their daily employment foon ceafes to become irkfome. They fee their little companions around them, ail engaged like themfelves; and from their cheerful countenances and general vivacity, it is apparent that they are contented and happy.

Mr. Howard once went through the houfe; and not only the apartments, but the paupers themfelves, particularly the children, underwent a very critical infpection. He obliged many of the latter to take off their fhoes and ftockings, and thew him the foles of their feet. He expreffed much pleafure and fatisfaction as to the mode in which the affairs of the houfe were managed.

The fituation is one of the moft healthy that could have been chofen, and at the fame time uncommonly beautiful. The front of the building commands a 
fine view of the town and fuburos of Shrewfbury. The trees of the Quarry form the appearance of a wood in front of the houres, above which the churches of St. Mary, St. Alkmund, and St. Chad, are particularly confpicuous. Beyond thefe objects is feen the round hill of the Wrekin, and others of the Shrophire mountains.-At a little diftance from this ftation, and in an oppofite direction, the Breiddin hills are vifible, and an extenfive tract of country towards Wales*.

Croffing the Severn, from the Houfe of Induftry to the Quarry, by the ferry-boat, I was foon afterwards thewn a few ancient walls of the houfe of Autin, or Augufine Friars. This ftood clofe to the river, at a fhort ditance from the Quarry. It is fuppofed to have been founded by fome one of the Stafford family.

The Grey, or Francifcan Friary, was fituated a little to the fouth of the fone bridge. Its ruins now form part of a dwelling houfe. It is fuppofed to have been founded fome time prior to. 1353 .

The Black, or Dominican Friary, ftood near the river, between the cafle and the ftone bridge, at the bottom of St. Mary's Water Lane. Its foundation is afcribed to Maud, the wife of Jetriy, lord

* For a very minute and interefting account of the Houfe of Induitry at Shrewfury, with many valuable obfervations on the fubject, fee the work of Mr. Woud, publifhed by Longman and Rees, 8vo. price 3 s. $6 d .-18 \mathrm{co}$.

Genevil, 
Genevil, about the year 1265 . The two fons of Edward IV., who are believed to have been murdered in the Tower by order of Richard duke of Gloucefter, afterwards king Richard III., are faid, with what truth I know not, to have been born in this friary.

\section{Pubilic Buildings.}

The Free Scbool ftands in a ftreet leading to the caftle. It is a large antique ftone building, with a fquare tower, and contains, befides a very good fchool-room, a dwelling-houfe, chapel, and library. In the latter there is a valuable collection of books, and feveral natural and artificial curiofities. This fchool was founded in 1552 by king Edward VI.; and the original building was confructed of timber. The prefent edifice was erected about forty years afterwards.

The Infirmery ftands near St. Mary's church-yard.

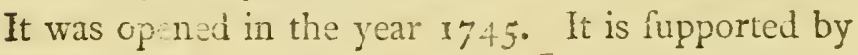
voluntary benefactiors, and its benefits extend not only to the town and county, but to all proper objects, without diftinction of place. The average number of in-patients is about five hundred, and of out-patients feven hundred.

Millington's Hofital is fituated on an eminence above Frankwell, a fuburb byond the Welh bridge. It is a handome b.:ck building, arid was founded in I7.34, under the direction of the will of Mr. James Milington, formerly a draper of Shrewibuiy. It 
maintains twelve decayed houfe-keepers (fingle perfons), and a charity-fchool, for twenty boys and twenty girls, from the diftrict of Frankwell, if fuch are to be found, and if not, from the neareft part of the parifh of St. Chad. No diffenters of any denomination can have relief from this charity: it is confined to perfons of the orthodox principles of the church of England.

St. Chad's Alms-boufes, for decayed old men and women, were founded in 1409 by Bennet Tupton, a brewer of Shrewibury. They are fituated in old St. Chad's church-yard.

St. Mary's Alms-boufes, in Ox-Lane, near St. Mary's church, were founded about the year 1460 , by Digery Waters, a draper. He is faid to have lived here among the poor people. They are confined principally to old perfons, and thofe from St. Mary's parifh only. The people have clothes, and a fmall falary allowed them.

The Charity-School in Back-Lane was founded in 1724, under the will of Mr. Alderman Bowdler. This is intended for poor children of the parifh of St. Julian, and if fuch are not found, of the parifn of Holy Crofs.

The Subfription Cbarity-School, for infructing and clothing poor chiliren, is fituated by the road-fide, leading to the abbey. It was begun in the year 1708. The boys are taught to read, and the girls to read, few, and knit. 
Befides thefe may be mentioned the Torun Hall, in which the affizes are holden, and where the magiftrates tranfact public bufinefs; and the Market. Houfe, where the drapers hold their market for Welh cloths and flánnels.

\section{History of Shrewseury.}

The town of Shrewfbury boafts a very remote origin, but the exact date of its foundation cannot at this day be afcertained. It is fuppofed to have been firft built from the ruin of the Roman Urica. nium, or the Vreken Ceafter of the Saxons, whofe fite has been difcovered at WTroxeter, a village on the bank of the Severn, about four miles diftant. The Wellh name for Shrewbury: was Pen Gwern, The Head of the Alder-Graves; and the Saxons called it Scrobbes Byrig, on account of the eminence on which it was fituated baing covered with wood. I have before related that it was once the capital of Powilland, and a feat of the Wellh princes.

In the reign of William III., Shrewbury was granted to Roger de Miontgomery, who fhortly afterwards founded the caftle and abbey. At this tine it was called a city, and had two hundred and fifty-two citizens. Whenever the king paffed through the place, twalve of the higheft order of thefe were compoilur, whether he was fleeping or waking, to altend on his perion; and as many, with hores and arns, were alo to attend him whenever he took 
the recreation of hunting in the neighbourhood. Thefe fervices were impofed as a punifhment; for, not many years before the conquelt, Edric Streon, duke of Mercia, having, near this place, lain in wait for, and murdered prince Afhelm, as he was return. ing from the chace.

The burgeffes of Shrewbury had many privileges even before the conquef; ; and Henry I. on the forfeiture of Robert de Belefme, fon to Montgomery, feized the town into his own hands, and granted to the burgefles their firft charter. By various grants and charters in this and fubfequent reigns, the burgefles, amongt others, were allowed the following privileges:-To hold all pleas except thofe of the crown:- to receive toll and cuftom from all the Welih that traded in the town.--They were exempted from pontage, toll, and all exactions of burgeffes throughout the kingdom, except London.Their goods could not be feized for any forfeiture made by their fervants. - They could in no cafe be fummoned to appear before any others than burgeffes, their peers. - No fherifi, or other officer, could difrain within the libertias of the town;-and no burgefs could be arrefted, nor have his goods feized. In the reign of Elizabeth the town was incorporated; and the charter of the incorporation was afterwards confirmed by Charles I. and James II. The corporation confifts of a mayor, twenty-four aldermen, forty-eight afliftants, and inferior officers. - The town returns two members to parliament.

Several 
Several parliaments have been holden in Shrewrbury. The firft that was fummoned formally by writ, met in September 1283 . By this, David, the brother of Lleweiyn, prince of Wales, was tried for high treafon, and condemned: he was the firft perfon who fuffered the death of a traitor, in the form of tire fentence now in ufe.-Another parliament was holden here in 1397 , which, on account of the great number of people that were affembled in it, was called the Great Parliament. By a ftrange conceffion of this parliament, Richard II. obtained an unexampled ftrctch-of power, that the whole govemment of a nation fhould devolve on the king, twelve pecrs, and fix commoners. A bull from the pope was thought neceflary to confirm fo irregular a proceeding.

Of the military tranfactions relative to this place, the moft important was the battle fought here in July 1403 , beft known by the name of The Battle of Shrexyloury, between lking Henry IV., and the foldiers commanded by Henry Percy, furnamed Hotfpur. It had been the defign of the infurgents from the north, to make themelves mafters of this town and caftle, and then to firengthen their forces by a junction with Owen Glyndwr and his countrymen. The activity of Henry prevented this junction, and faved his crown. Coning up with Percy's army at this town, the high fpirit of that hero would not fuffer him to wait the arrival of Glyndwr, who was encamped near Ofweftry, but he hazarded a conteft 
even with his inferior force. The fight commenced early in the morning, and after a violent ftruggle of three hours, Percy's party was completely routed, and himfelf, and about five thoufand of his men, were flain. The earls of Worcefter and Douglas were taken prifoners, the former of whom was foon afterwards beheaded at Shrewibury.-The fcene of this contention was a place fince called Battlefield, in the parifh of Albrighton, about three miles diftant.

One of the ordinances made by Alcock, bifhop of Worcefter, and Anthony, earl Rivers, in April $147 \hat{\partial}$, for the government of Shrewibury, was as follows:

"Firft that the bayliffs for the time beinge iuftly, truly and endifferently thall execute their offices, accordinge to their liberties and laudable cuftomes, without any corruption favor or parcialitie. And that they fee yf any perfon come into the towne there abydinge two days fufpicioufly, without any lawfull errand or occupacion, that then he the third daye be putt in prifon there to remayne till he have founde furety of his good abearing; or els to auoyde the towne." Any perfon fo committed by the warden, and four men, was not to be declared out of ward by the bailiffs without confent of the fame warden and four men. Thefe injunctions were to be obeyed, under the penalty of a hundred pounds, half to be paid to the king, and the remainder to the town *.

* Cotton MSS. in the Eritih Mufeum; Vittellius, C. i. 
In the year 1485 , Henry earl of Richmond, afterwards king Henry VII., arrived at Milford Haven, from Bretagne, and he had fo far paved the way for his reception in this country, as to meet with little oppofition till he came to Shrewbury. Here, howcver, the gates were thut againft him. He fent meffengers to demand that the gates be opened to admit the rightful fovercign of England. The head bailiff, whofe name was Iriytton, appeared at the gate, and anfwered, "I acknowledge no fovereign but king Richard III., whofe fervants I and my townfmen are. I folcmily fwar, that before any otíner enter this torun, be frall fir.t make bis way over my body. By this expreffion he mearit that he would fuffer himielf to be flain, rather than admit any but his acknowlciged monarch. The meffengers returned to Henry, and they were again fent on the following morning, to requeft that the earl of Richmond might be fuffered to pafs. They pledged themfelves, for the earl, that no injury whatever flould be done to the town, or its inhas bitants, and that Mytton himfelf fhoulci alfo be faved from the guilt of perjury. The bailiff having in fome meafure changed his mind fince his laft interview with the meffengers, did not object to thefe lenient terms. Henry entered the town by fepping over the body of Mytton, who laid down for the purpafe in the gatewaj.-From hence he paffed on to Bofworth-Field, where the decifive battle was fought in which Richard III. was Ilain. 
It is affirmed of this entry of the army of Henry VII., that a malady unknown before was introduced into Enyland, called the fweating, ficknefs. It raged for upwards of fixty years in the kingdom, carrying off many thoufand people, and ait laft ended in this town, in the year I551. A fhort time berore this period it was fo violent here, as to tuke off no fewer than nine hundred and rinsty purfons in the courfe of a few days. The difeare began with a violent perfiration, which continned till cither the death or recovery of the patient. It fcldon lafted more than twenty-four hours, fo that thofe who happened to be taiken ill in the ciay time, were put to bed with their clothes on to wait the event; and thofe who were feized in the night were ordered to remain in bed, but on no account to fleep. This fingular and dreadful malady feems to have origin nated among the levies that Henry had raifed on the continent, which had been raked out of hofpitals and gaols, buried in filth, and, without any autention to their health or comfort, immeciately crowled on board the tranfports.

In the civil wars, Shrewfoury was garrifoned for the king, and frr Michael Earnly was made governor. General Mytton made two unfuccefsful attempts upon it, but in February i' 644 the place was furrendered to him. Crowe, the lieutenant, was afterwards hanged for his treachery, or cowardice. The governor, and feveral perfons of rank, were made prifoners; and the town was plundered. Mytton, foon after the 
fiege, was made governor, and he received the thanks of the Houfe of Commons for his good fervices.

In a chronological lift of remarkable events at Shrewbury, are recorded the following fingular occurrences :

1282. This year the theriffs of Salop and Stafford were compeiled to provide two hundred wood cuttcrs, to cut down timber and other obftructions, in order to make way for the king's army to enter into Wales.

1427. A bye law was made againft fwine wandering about the town: the penalty was cutting off an ear for each of the two firft offences, and forfeiture for the third.

1519. The brewers were ordered by the corporation not to ufe that wicked and pernicious weed, hops, in their brewings, under the penaliy of $6 s .8 d$.

I 547. This year Adan Mytton and Roger Pope, the bailiffs, ordered the picture of our lady to be taken out of St. Mary's church; and the pictures of St. Mary Magdalen, and St. Chad, out of St. Chad's church, and burned.

1552. The magiftrates of Shrewibury were reftrained by act of parliament from licenfing any more than three perfons to fell wine within the town.

1585. On the 15th of May, lord Robert Devereux, earl of Effex, came through the town, before whom the free-fchool fcholars made feveral orations, as he paffed through the caftle gates; they ftanding in battle array, with bows and arrows in their hands.

16: It was in this year ordered by the corporation, that two perfons fhould be conftantily ftationed in each ftreet to fearch for-vagrants. 


\section{Churchyard, the Poet.}

As I have fo frequently had occafion to quote the writings of Churchyard, it is but proper that he fhould have a place at the end of this chapter. Very little is, however, known of his life. He was boin at Shrewbury, a defcendant, as he fays himfelf, "of right good race," and flourifhed in the reigns of Henry VIII., Edward VI., Mary, and Elizabeth. His verfes are neither elegant nor fmooth, but they are generally fuppofed to abound in faithful defcription. His Worthinefs of Wales was his principal work, but he alfo wrote in verfe, "A Defcription and Difcourfe of Paper, and the Benefit it brings, with the fetting forth of a Paper Mill near Dartford." - He died about the year I 570 ; and his epitaph, written by himfelf, is preferved in Camden's Remains :

Come Alecto, and lend me thy torch, To find a Churchyard in a church porch;

Puverty and poetry his tomb do enclofe, Wherefore, good neighbours, be merry in profe. 


\section{$(244$}

\section{CHAP. XXIII.}

The Maniers and Customs of tire Wersh.

Account of the "Yetho Manners in the Truclfih Cintury. - Mocis of Fighting.-Domefic Cu,Roms and Drejs. - T be Officers belonging to the Cour: in the Tenth Century. - The OfNecrs of the Nobinty.$V$ arious fungular Laws anel Cufloms of this Period. - itite of Socicty in the fubfequent Centuries. - The Lazes of the Chace. - Tha ancicut Games. - Wi elfb and Englifis Contcis after the Infur rection of Glyndiur.- ThE MANNFRS OF THE MODERN WELSH.-Impofitions fometimes prabified on Englifis Travellers.-Irafcibility.The Welg Cottnges. - Women. - Curigfity. - Superfitions. - Account of a fuppofed Find of aërial Bings called Finockers. Witches. - Coelcerth. - Yr Eryr. - anaull Corph. O Offering of Enemies.-Wells of Scints. - Plygain.-Lecks on St. Davill's Day. - Terming. - Mrode of Courtjuip calied Bundling.-Cuffoms at Wedaings. - Funerals. - Ofierings at Funerals. - Reajon for not interring on the Nortb siles of Cluurcies. - Pluminger the Graves.

If accounts of the manners and habits of life of the inhabitants of difant nations be found interefting; the aborigines of our own ifland, and a people that now form part of our owncommonwealth, muft certainly be entitled to fome attention. Compollicd, as the Welh people were, to feek for fhclter in this obfcure corner of Britain, near fourteen centuries ago, from the perfecutions and treachery of their Saxon foes, their manners have had many fingular 
and interefting fatures, from the moft remote psriods of their hiftory. Their own referved difpofitions, originating in a natural want of confidence in thofe from whom they had experienced only injuries and onpreffion; and the mountainous nature of their country, entirely fecluded them from all commerce, and prevented them from fettling any amicable connexions with their neighbours. They therefore retained their own inflitutions, and their own paculiar cuftoms, for many fucceeding centuries. "An account of fome of thefe have been tranfmitted to us by their bards, and of others by their hiftorians.

Gerald Barry, (better known as Giraldus Canbrenfis,) archdeacon, and afterwards bifhop of St. David's, travelled through Wales, his native country, in 1187 , with archbifhop Baldwin, to preach the crufades, and convert the unenlightened Welih*. He has left us, though mingled with much fuper. ftition, and with many incredible ftories, a minute, and, as it is generally believed, an accurate detail of the character of this people.

Ire informs us that the pride of anceftry was carried amongit then to the greateft lengths; and that this fpirit was fo deeply rooted, that even the loweft of the peafantry could regite from memory the names

* Their difcourfes were entireiy in Latin, notwithet unding which tirey made multitudes of profelytes! Baldwin and Gitaidus have not inaptly been comparca to Don Quixote ard his fquire Sancho Pança. 
of their predeceflors for many generations. - Their pafions were violent, and their refentments keen. They were vindictive and bloody in their anger; and when occafion ferved, would fometimes revenge themfelves for injuries committed at very remote periods.

They were a nation of foldiers, every man being obliged to bear arms in times of diftrefs. The armour was light, confifting only of a fmall target to defend the breaft; and their weapon was a javelin. Thus furnifhed, they profecuted a war rather by incurfions, and forced marches, and conquered their enemies rather by furprize, than by real ftrength or courare. In a pitched battle, they were no way equal to the Englin foldiers, who were clad in heavy armour, and were further defended by large helmets. Their principal manœuvre was to draw their enemies to engagement near the edge of fome extenfive morafs, over which their lightnefs and agility would allow them, in cafe of danger, to retreat in fafety. They fought on foot, and made one furious onfet: if this was refinted, they were immediately thrown into confufion, and could not be rallied till they arrived in fecurity amongft the mountains or moraffes, where they were confident their heavily armed foes would not dare to purfue them. Here they waited in fecurity till another opportunity occurred of falling upon their enemies.

The greateft number of the ancient Welh led folitary lives in the forefts, on the borders of which 
they formed their dwellings. The huts of the lowert clafs were conftructed with little art or expence, their exterior being nothing more than a covering of interwoven oziers.

They defpifed trade and the mechanic arts; yet, though they had little money; they were altogether without beggars. The liberality of the fuperior orders was fuch, that all partook of their bounty. The hofpitable entertainment both of friends and firangers was efteemed by them a virtue. As foon as a traveller entered the houfe of any of the great men, he delivered his arms to the guard; and fome of the domeftics immediately brought to him a reffel of water. If he intended to remain all night, he fuffered them to walh his feet: if he merely withed for refrefhment or repofe, he rejected this fervice. This offering of water for ablution was their mode of giving invitation.

Almolt every houfe was provided with a harper, and the frangers were entertained in the day time, (when they did not prefer the amufements of the chace,) with the converfation of young women, and the mufic of the harp. Giraldus is particular in his encomiums on the talents of the WJelfh people in mufic. He fays that moft of them could play on the harp, and that in the wit and ingenuity of thir fongs, and in extemporaneous effufions of genius, they greatly excelled all the other weftern nations. - The frangers were all affembled in the evening to an entertainment that was provided for them in 
the hall, according to their numbers and rank, and according to the ability of the loft. They were placed by threes; and the difhes were put on frefh ruhles. In thefe entertainments there ias no p:ofufion, nor were any incentives to cxceis introduced. I prefune they placed the difhes on their knees, for Giral'us informs us they had no table. The holt and hofeis remained ftanding during the whole tine, to fee that every one was ferved with as much food as he wanted.- Then the hour of ret approached, the domeftics fcattered a few ruthes along the fides of the room, and covered thefe with a hard and rough cloth, the produce of the country, by way of a bed. On this they all laid down together, in the fame drefs they had worn during the day. The fre was kept burning all night in the middle of the room; and thofe who found themfelves cold, or found the bed, from its hardnefs, uncomfortable, occafionally refoited to $i$.

The drefs of the men at this periodifeems to have confifted, principally of a kind of fhir $t$, and a fmall cloak: 'they ihaved away every part of their boards, except a whifker on the upper lip. Both fexes were very particular in prefering the whitencfs and elegance of their tceth. They were almoft continually to be feen in the act of rubbing them, fometimes with a piece of green hazel, and at other times with a bit of woollen cloth. Their invariable abfinence from hot food tended greatly to preferve their teeth. 
In the tenth century, about two hundred and fifty years previous to the date of the account given by Giraldus Cambrenfis, the royal manfion confifted only of a hall, pariour, and bed-rooms; butlery, fable, dog-kennel, granary, and bakehoufe *.

At this period the drefs of the ling confifted of a mantle and tunic, fhirt, breeches, fhocs, ftockings, and gloves, and a cap made of different kinds of nkins. The queen's drefs did not differ much from this,-No other fuel was ufed than wood. The bed was of firaw: indeed, ftraw was continued in the royal bed-chambers of England, till even towards the conclufion of the thirteenth century.

There were twenty-four principal oficers belonging to the court. - Of thefe, the firt in rank was the ' penteulu,' cr mayor of the palace. This perfon was always a prince of the blood; and he had, with various perquifites, a falary of three pounds a year. One part of his duty was to entertain at his table fuch perions as had been turned out from the royal board for mifbehaviour, and to intercede for their pardon. The chaplain was fecond in rank. Next to him fucceeded the ferward of the houfenold. The latter provided the meat and liquor, was mafter of ceremonies, and the tafter. Among his perquilites he was allowed as much, "plain ale" from every cafk that he brought in as he could reach with

* Leges Wallica, lib. i. c. 47 - From thefe lawis, foinded by Howel Dda, Howel the Good, about the year 950, much of the inmediately enfing account has been extracted.

his 
his whole middle finger when immerfed; as much "fpiced ale" as he could reach with the fecond joint; and as much " mead" as with the firlt joint of the finger immerfed. The fourth officer of the court was the bead falconer. When this perion gave any entertainment in his private apartments, he was entitled to three horns of the beft liquor of the palace, and one difin. He was required to bring his cup in perfon to the hall at every repletion of it, left he fhould drink too much, and nerglect his birds. When he had been fuccersful in his fport, the prince rofe to meet him, and fometimes held his ftirrup while he alighted from his horfe. The court poet, or barper, filled the eighth place. It was his duty, when the king's domeftics went out on any plundering expedition againft the Englith, to attend and play before them: and when the armies were about to engage, he fung to tham the fong called " The Monarchy of Britain." The ' gofdenww;, or king's forgemt, was ninth in rank. One part of his duty was to prevent unbecoming noifes in the hall by ftriking the columns with his wand. The cloief buntfman, and the prefudent of the grooms, ranked next each other. 'The former, at a certain time of the year, was allowed to hunt only for the king, but at other fcaions he was at liberty to do this for himfelf. His horn was formed from that of an ox, and was valued at a pound. He was allowed every winter an ox's hide, to form his lealhes of, and in fummer he had a cow's hide to cut into fpatterdathes. 
dafhes. The twelfth place was given to the phyy $\mathfrak{i}_{-}$ cian, or rather the furgeon. 'For flight wounds of the perfons attendant on the court, he had as a fee that part of their garment which had been ftained by their blood. He had, however, an allowance in money, of a hundred and eighty pence, for more ferious injuries. The porter was reckoned among the officers of the court. This perfonage provided ftraw for all the beds, and kindled all the fires in the palace. He was obliged to know the face of every man who was entitled to admifion into the royal hall. One, of his perquifites was, of the fwine that paffed through the gate, any fow that with one hand he could lift up by the brifles, fo that her feet fhould be as high as his knees. He was allo entitled to every animal without a tail that paffed through the gate :-and, at each of the three great fentivals, he was allowed to drink three horns of an highly valued liquor, called " the Twelve Apoftes." Among the remaining officers I find the mafer of the bounds, the butler, the cook, the lampligbter, and the chambermaid.

In this eftablinment we obferve tine mafter of the hawks, the chief groom, the poet laureat, the lamplighter, and the cook, all ranked immediately among the great officers of fate. Such a precedence was naturally given them in a court, generally devoted, as all criginally ware, and as in all illiterate ages ever will be, to the pleafures of the featt, and the diverfons of the chace. 
The different ranks in fociety were, the king, dukcs, cars, lords, barons, efquires, yeomen, vaffals, and faves *

The onferes of the principal nobiliey were, a fteward of the loufhold, chamberlain, chaplain, almoner, ufher of the hall, gentleman of the horfe, butier, cook, baker, door-keeper of tha chamburs, porter, groom of the hore, and apparitor, with their afliftants.-One part of the uhir of the hall's duty was, every day after dinner, to deliver, in an audible roice, an account of the expences of the table for that ciay, and to admonif all the perfons prefont to cconomy.

The king had the right of commanding evcry parfon within his dominions to join his army at all tines when he thought it necefiary, and once a year he had the power of fonding them even beyond the linits of his country.-During the abfence of the king; the auhority of the court was vened in the chaplain, the neward, and the judge.

After there particulars rutive to the W $\mathrm{W}$ ld court, and the himh ranks of fociety, I fuall recite fome particulars from the old laws, and then proceed with the fubfequent hiftory of the manners of this people.

Little attention or rofpect fcems to have been paid by this race of wariors to the fair fex. By one of thir laws it is decreed, "thut whofoever.

* Drenin, Tw, for, Jarll, Arglwydd, Dawn, Uchelwr, Gwrëang, Alltud, and Cath. 
thould trike the queen, or fnatch any thing forcibly out of her hand, fhould forfeit the royal protection." -Nothing can furely exceed the brutality and injuflice of the following pinifment for feduction. After complaint had been made by the female of the defertion of her lover, the jutge ordered that the offender thould provicie a buli at fome fixed time and place. As foon as it was brought to the fpot, the tail was fhaven, and well greafod; and, thus prepared, was infroduced through a weker door. Here the female was to lay holl of it; two men were to goad the beutt; and if, by dint of firength, the could retain the bull, the was to have it as a fatisfaction for the injury, fhe had fufained: if not, the got only the greafe that ramained in her hands.

The Britin fair were declared marriagable at the age of fourteen. The lover adurefod himfel in all caies to the father of the maid. If he ayeed to their union, he introduced his daugher to har futor. A few clays concluted the whole tufnces, for the father had an authority fo abfolute, that his dangh. ter had not cren the power of refufinl. If the difliked the lover whom he had recommended, fhe had no other refource than cither the tears of intreaty, or the dangers of night*. If, however, after maniage, the continued to dinike he: huband, fhe might, by the Wellh laws, be, feparated from him on vety fiight grounds; it was a fufficient caufe if fhe difco-

* Whitaker's Hiftury of Manchefter, ii. I36. 
vered that he had an ill-fcented breath. With re. fpect to the hufband, he was not allowed to civorce his wife, but for the moft ferious offences. If the called him opprobrious names, pulled him by the beard, or iquandered away his goods, the injured fpoufe might give her thrce blows with a ftick on any part of her body except the head. If, however, he beat her more feverely, or for a lefs caufe, he was liable to a heavy fine.

The compenfation for the murder of a mayor or chancellor was a fine of a hundred and eighty-nine covrs. For the murder of the chief of a family, the fine was thrice this number of cows; of a king's villein, it was fixty-three cows; and a pound and a half was reckoned full fatisfaction for the murder of a found-bodied flave. - The barbarous cuftom of exempting from capital punißment, even the moft atrocious afiafin, by payment of a fine, was retained much longer in this country than in any other part af Britain. It was practifed by the lords marchers in the fifteenth century, and even in the year 1536 an inftance occurred in Merionethfhire of five pounds being received in compenfation for the commifion of a muruler*-For leffer offences this people had various atonements. A Welfhman, for the lofs of his finger, received from the offender one cow and twenty pence; for the lofs of his nofe he had fix oxen, and a hundred and twenty pence; and for being pulled by the hair, a penny for every finger,

* Wynne, 407 . 
and two-pence for the thumb, the infruments of infult.

A Welfhman, whole born, having no debafel blood, was accounted a free native gentleman.

If a villein, with confent of a baron, took any one of the baron's fons to bring up, that child was made by the laws a participator in the property and inheritance of the villein, in the fame maniner as his own children.

The Welfh laws prefcribed three fciences which no villein could texch his children without the confent of his lord; but if the lord fuffered any of them to fludy one or more of the fciences for a certain time, fuch children were by that means rendered free, and could be no longer ranked among the villeins. Thefe fciences were fcholar/hip, bardifm, and fmithcraft. Of the latter, however, it fhould be remarked, that the term fmithcraft had, doubtlefs, a much more comprehenfive fenfe than we at prefent give to it. The profeffor of fmithcraft mut have been acquainted with different branches of knowledge which are now practifed feparately, fuch as the arts of raifing the iron, and other kinds of ore, and converting them into metal.

The Welth had among their laws two very fingular ones. If any perfon killed the cat that was about the king's palace, the was to be hung up by the tail in fuch a manner that her head fhould touch the floor, and fo much wheat was to be paid as a forfeit, as, being heaped around her, would 
cover the tip of her tail. - If a dog was of fo favage a difpofition as to bite people who did nothing to offend him, and had done it thrice, and his mafter fill neglected to kill him, he was to be tied to his mafter's foot, and not at a greater length than two fpans, and in that fituation to be killed. Three cows were alfo to be paid as a fine to the king.

The Welfh princes, and other lords of particular territories, were owners in chief of all the lands, and fovercign lords of all their fubjects and bondfmen. To thefe they difributed the townhips and hamlets, to be' holden by particular tenures, and fubject to fuch conditions as the owners thought fit to impofe. Thefe tenants were either free natives, or perfect flaves. The former had the liberty of going whither they pleafed, had the uncontrolled power of buying and felling, with other immunities; but the others conftituted even part of the property of their lords, who could difpofe of them in whatever manner they pleafed. They had the power of offering them to fale in the fame manner they would their cattle. This inhumąn cuftom prevailed in Wales for many years after the death of the laft prince of Wales. There is yet extant a deed of fale, dated even fo late as the year I 448 , by which feven llaves and their families became transferred from one perfon to, another, in the townmip of Porthaethwy in Anglefea.-All the tenants, both bond and free, were fubject to feveral fervices which they were obliged to perform. They 
were not only compellable to attend the king in his wars, but they were obliged to attend their refpective lords when engaged in their petty contentions, fome of them for a limited time, and only to particular places, but others indefinitely to any part of the country, and what was of fill more effential confequence, at their own colt. Certain of them had to maintain the prince's fteward, his horfes, cattle, falconers, lawks, or fome other part of his eftablifhment. In the building of houfes, or mills, fome of them, from their tenures, were obliged to carry the ftones, others timber, fome to repair the roofs, and fome the walls. Some had alfo to repair the wears, fome to hedge the warrens, and fome to attend the offices of the larder or lkitchen.--Befides thefe tenures, there were certain lands that were holden, not under any lord or prince, but of faints, or the patrons of churches. The tenants of this property filed themfelves abbots. Of thefe there were feven in the ifland of Anglefen, and a great number in the other parts of Wales*

By the old Welfh laws, every man's inheritance was civided among his children, but the youngeft fon had the principal houfe. The lands, even till within a few centuries, were in no cafe fuffered to devolve to a female; rather than this they efcheated to the lord. The owner had, however, the power,

* Rowlands, $321,122,127.129 .133$.

$\mathrm{V} O \mathrm{OL} ; \mathrm{II}$; 
which he frcquently exercifed, of mortgaging them, and fometines by way of providing a marriage portion for the daughters. Thus Robin Vaughan of Henblas, charged his lands with a mortgage of twelve pounds, in part of his daughter's marriage. portion *.

The ancient Weln followel the pleafures of the chace with great avility, and various kinds of animals were the objects of their purfuit. Among thefe have been enumerated the ftag, the boar, a fwarm of bees, the falmon, the cock of the wood, the fox, the hare, the roe, and "climbing animals," fuch probably as martins, fquirrels, and wild cats. Some of thefe do not accord with the prefent ideas of objects of amufement in the chace; they were, however, all compreinended in the code of laws relative to this diverfion, formed by one of the Weln princes in the twelfth century.-The mode of hunting thole animals that could be purfued by dogs, was with hounds or greylounds; thefe were held in leafhes, and from thence let 1 lip at the aninals. No perfon was allowec to kill an animal of the chace on its form, or at reft, on pain of forfeiting his bow and arrows to his lord. When feveral hounds, the pro. perty of different perions, were let nlip at an animal at the fame time, the perfon whofe dog was neareft the beaft when it was laft in fight, was entitled to 
the fin. A' bitch was excepted, unlefs it could be proved that the was pregnant by'a dog that had before won a fkin.

Every perfon who carried a horn, was to be fo far acquainted with his purfuit, as to be able, whenever he was called upon, to give a fcientific account of the nine preceding objects of the chace. All perfons unable to do this, were confidered only as pretenders to the fcience, and, confequently, whenever fuch were difcovered, they forfeited their horns.

The king had the power of huinting wherever he pleafed within his own dominions. If, howerer, an animal was purfued and killed on any genttleman's eftate, and not followed and claimed by the huntfman the fame night, the owner of the land might convert it to his own ufe; but he was under a ftrict injunction to take good care of the dogs, and to preferve the fkin.

A ftag at this period was efteemed equal in value to an ox; a hind to a well-grown cow; a roe to a goat; and a wild fow to a tame one. Wolves, foxes, and fome other noxious animals, had no value, and any perfon was allowed to kill them. The hare had no value; and for this fingular reafon, becaufe it was believed every other month to change its fex: the fame was the cafe with the badger, becaufe in fome years it had a difeafe which the Wellh called the meafles. 
This people had ancicnily twenty-four zames. The firft and principal of thefe were what they dencminated the fix fiats of acivity: running, leaping, fwimning, riding, and the difplay of ftrength in fupporting and huring heavy weights.- T'o thefe fucceded the four cxeritis of wcapons: archery, throwing the javelin, huring with a fling, and fencing with a frord and target, or a two-handed fword. The latter whe included alfo playing with the quarterfaft.-Next came the three rural fports: lumting, fining, and hawking:- then the feren domejic and literary games: poetry, playing on the harp, reading Welh, finging a fong with the harp and crwth, finging an ode in four parts with accentation, heraldry, and embaify :-and, laftly, the four inforior games: ches, draughts, or thuilleboard, back-gammon *, and tuining the harp.

In confeguence of the dreadful contefts that took place betwixt the Welth and Englifh during the rebellion of Orin Glyndw, in the beginning of the fifteenth century, an act paffed the Englifh parliament in 1401 , by which any whole-born Welhman was prevented from purchafing property, or being male a burgeis in any of the Englin towns; nor wcre this pcople allowed to hold any civil ofices whatever in England. Complaints were daily mad:

* Our game of back gammon fecms to have had its origin in this. The words bacb and gammon fignify in the Welh lano guage, an inferior laind of battle or conteft. 
of their incurfions, and of their ftealing cattle, and other property, fometimes to a very great amount. It was in confequence enacted that, in any cafe where reftitution was not made within feven days, it was lawful for the perfons thus aggrieved, to arreft any Welfhmen who came with cattle or goods for fale from the diftrict where the offenders refidecl. Thefe were to be detained till full fitisfaction had been made.-From this time, for the fpace of three years, no Englifhman was allowed to be convicted at the fuit of any Welhman in Wales, but by Englifh juftices, or by the judgment of whole-born Englifh burgeffes.

By an act of parliament two years fubfequent to the above, it was directed that no Englifh burgefs who married a Welfh-woman fhould have franchifes with the Englifh burgeffes; and all fuch perfons were prevented from holding any office in Wales, or in the marches.-This ftatute declares that the Welfh harper"s, who are here denominated "wafters, rymers, minftrels, and other vagabonds," had moved fedition, provoked loofenefs among the Welfh, and greatly impoverifhed them; it was therefore ordained that they be no longer "fuftained to make comorthies, or gatherings on the people there."-No Welfhman was allowed to wear arms, or to bring any arms or victuals into any of the Welfh towns, without efpecial licence for the purpofe. Nor could a Welfhman have any houfe of defence; but all the Wellh cafles and other fortreffis were directed to 
be garrifoned by Inglifhmen only, entire ftrangers to the Welfh, who fhould be fent from fome diftant parts of England.

The Welh people appear in their turn to have entertained equal feverity againt the Englifh. Prior to the reign of Henry $\mathrm{V}$. they had a cuftom, called the afach, by which it was neceflary to have the oaths of three hundred men, before an Englifhman, who had been accufed of any crime, could be acquitted. Before its abolition by this monarch, an accufed Englifhman was liable to continue in gaol for life; as among his enemies, even a far fmaller number of compurgators than this ftrange law re: quired could not have been obtained. Fienry ordained that every attempt to enforce this cuftom? flould be a penal offence, and the profecutor yas liable to two years' imprifonment, to pay treble cofts, and a fine and ranfom before he could be releafed.

It appears by an act paffed in the reign of king Henry V., that many of the Welh had entered the Englifh counties, and hiding themfelves in the woods during the day time, had frequently in the night carried off into their own country the king's liege fubjects. There they had fometimes detained them amongt the mountains for fix months and upwards, till they were ranfomed by their friends. Perfons thus offending were declared guilty of felony, and a mode is prefcribed by this act for their feizure and punithment.

Thefe, 
Thefe, and other enormities, were found in the fubfequent reign ftill to be practifed, and an act of parliament was pafied fill further to reftrain the Wellh in their outrages. This, however, feems to have had little effect, except for the moment, for they foon relapled into their former habits.

Even in a ftatute of fo late a period as the year 1536 , it is declared that " the people of Wales, and the marches of the fame, for long time paft, have continued to commit divers thefts, murders, rebellions, burnings of houfes, and other heinous mifdemeanors, which feem deeply rooted in this people, as not likely to ceafe unlefs by fevere correction and punifhment." In confequence of the difficulty of putting an end to thefe outrages by lefs powerful means, an act was paffed in the following year, by which the principality of Wales was declared to be thenceforth " incorporated, united, and annexed to the realm of England :" that all the natives fhould enjoy the rights and privileges of Englifhmen : and that the laws, ordinances, and ftatutes of England, and none other, fhould for ever afterwards be ufed as the laws, ftatutes, and ordinances of Wales.-By this act four new Wellh counties, and one new Englifh county, were created, namely, Brecknockthire, Radnorfhire, Montgonery hire, Denbighthire, and Monmouthhire. 


\section{This Matigers of THE MODERN TVEtsh.}

From ancient I now defcend to modern times; and from defcribing that hardy race of warlike chan racters which were witi fo much difficulty fubdued by the Englifh monarchs, I proceed to make fome remarks on their prefent fate, in which this poople enjoy a degree of happinefs and tranqquillity that in! feudal times the cominy never experienced.

While quar:els rage did nou ifh ruirieft wrack, And Owen Glyndore fet blosdie broyles abroach;

Full many a towne was fpoyld and put to fack, A ald cleane confirn'd, to countites foule reproach. Great calles mis'd; fayre builuings burnt to duit, Such revel reigned, that men dictive by lutt:Brit fince they came, and yielud duto lawe, Moft meeke as lambe, within one yoke they diawe.

In thofe mountainous and fecluded parts of Walcs, as fome of the interior of Cacrnarvonthire, Merio. nethinire, and Denbighnire, that are yet fcarcely known to the Englifh tourit, the manners of the inhabitants differ very effentially from what will be obferved near any frequented road. The peopla feem there to have an innocence and fimplicity of character, unknown in the populous parts of oux own country. Among thefe it is that we are to fearch for thofe original traits, and that native hof? pitality, fo much the boaft of the Welfh writers. Wherever the Englifh have had uninterrupted com. munication, the money of which they have been fo 
lavifin has afrorded, an irrefiftible temptation for the lower claffes of the inhabitants to practife impofitions: in fuch fituations the people differ little from the like clars amongft us, On all the great roads, they feem to pride themfelves in being fufficiently expert to over-reach their Saxon neighbours in any of their little bargains. $\Lambda$ Welfh gentleman of undoubted veracity informed me, (and in various inftances I have myfelf experienced its truth, ) that it is a common practice amongft his countrymen, to ank for any article they have to offer for fale nearly double the fum they will take; thofe perfons who are acquainted with thefe practices never give them the full price for what they purchafe. I have good authority for afferting that at fome of the inferior inns, if an Englihman fits down at table with Welfhmen, the charge for his eating will be at leaft one third more than that of each of the reft of the company. This is a provoking impofition.

A ruftic bafhfulnefs and referve feem to be general features in the character of the Wellh people, and frangers, unaccuftomed to their manners, have often miftaken thefe for indications of fullennefs.It is ufual to fay of them that they are very irafcible. This may be the cafe, but from what I have myfelf feen, I am inclined to think, that the natural rapidity of their exprefiion in a language not underfood, has often been confrued into pafion, without any pther more certain grounds. Perfons who form thicis ideas from the opinions of others, without being 
being at the trouble of making obfervations for themfelves, are often deceived and mifled. Such, I am confident, has been the cafe a thoufand times in the judgments formed on the prefent fubject.

The loweft claffes bear indications of extreme poverty, yet they feem to enjoy good health. Their dwellings are cottages, or rather huts, built of ftones, whofe interftices are clofed with peat or mud. On a mere infpection, they would feem the habitations of wretchednefs. They are in general fo dark, that, on firft entering, the glare of light down the chimney alone takes the attention. The following is a good picture by Mr. Hutton of one of the better kind of cottages made uncommonly neat for the celebration of a wedding dinner:

Arriving, I crept through a liole in the donr,

Some ftones were laid down, and fome not, on the floor.

The whole was ore dark room, with three windows fo fmall,

That the light down the chimney quite out ftript them all.

But this great relief came to foften their cares,

Neither fober nor drunk could they tumble down ftairs.

'Two beds grac'd the manfion, which made it appear

That cleanlinefs, prudence, and order reigned there.

The tables and cupboards, which, opened to view,

Shew'd the hand of induftry had polifhed their hue.

The fhelves and their crockery, both china and delph,

iVere clean, and were orderly rang'd on the fhelf.

Dad, mam, and nine children, which fortune beftow'd,

In harmony liv'd in this darkfome abode;

Nor can we confent to call thofe people poor,

Where prudence fteps in, and bars want from the door. 
The ufual food of the labouring Welfh is bread, cheefe, and milk; and fonctimes what they call Atumery, a compofition of oatmeal and milk. Animal food and ale are by no means among their uiual fare.

The women of the mountainous parts of the country are generally of a middle fize, though more frequently below that than above it. Their features are often very pretty, but in point of figure they are in general uninterenting; and their long, and thickly matted hair, crowned with hats fimilar to thofe worn by the men, affords the unpleafant idea of a due want of cleanlinefs. They wear long blue sloaks that defcend almoft to their feet. 'Thefe they are feldom to be feen without, even in the hottelt weather; owing to the frequency of fhowers in a country furrounded with mountains. On their legs they have blue ftockings without any feet to them: they keep them down by means of a loop faftened rounid one of the toes. In the more unfrequented parts the women feldom wear any fhoes, except on a Sunday, or the market-day, and even on thofe days they often carry them in their hands as they go along the roads. I have fomeimes feen fix or eight of them, after their journies from the adjacent villages, feated on the bank of a rivulet, in the act of wafhing their feet previoufly to their entering the towns. During thefe journies they often employ their time in knitting, and a heavy fhower of rain will not fometimes compel them to give up their work. 
work. Their employment within doors, befides their family duties, is chiefly in fpinning wool.

What has been repeatedly afferted of the Welfh people, that they are naturally inquifitive and curious refpecting ftrangers is certainly true, but it is a circumftance by no means peculiar to this country. In all wild and unfrequented parts of the world it is the fame, and it is in fuch parts of Wales that this difpofition is chiefly obfervable. It is eafily accounted for when we confider their manners of life, and general ignorance. Surprize on the appearance of ftrangers, where in their limited ideas there could feem no inducement to repay the trouble or expence of a journey, would naturally excite their woncer, and this as naturally leads to the queftions "Where clo jou come from ?" - "Why do you come here?" -and, "Where do you go to from hence?"Unfatisfied with my anfwers, that I was an Englifhman come to vifit the mountains and waterfalls, I have often and often been afked with the utmort fimplicity, "Are there then no rocks nor rivers in England?" In all accounts of travels through unfrequented countries we find this difpofition to curiofity very common, and a flight acquaintance with the nature of the human mind is fufficient to allay any furprize that may be excited in difcoyering that it is prevalent in Wales.

They are much inclined to fuperftition, but in all countries we find that there are multitudes of weak 
and foolifh people. In England, moft of the peafantry fwallow with credulous avidity any ridiculous ftories of ghoits, hobgoblins, and fairies. There is, however, in the Welfh, certainly a greater inclina. tion to credulity than what at leaft an Englifhman can difcover among our own people. There are few, indeed, of the mountaineers of Wales, who have not by heart a ftring of legendary ftories of thofe difembodied beings. - The cavern in Llanymynech hill, not far from Ofweftry, has been long noted as the refidence of a clan of fairies, of whom the neighbouring villagers relate many furprizing and mifchievous pranks. Whilft they have ftopped to liften at the mouth of the cave, they have fometimes eren heard the little elves in converfation, but this was always in fuch low whifpers, that (with reverberation along the fides and roof of the cavern) the words were rendered indiftinguifhable. The ftream that runs acrofs a diftant part of this cavem, is celebrated as the place where the fairy wafherwomen and labourers have been heard frequently at work.

Confiderably allied to the fairies is another fpecies of fuppofed aërial beings, called by the Welfh krockers. There, the Wifh miners fay, are heard undraground, in or near mines, and by their noifes gencraily point out to the workmen a rich vein of ore. The following are extracts from two letters on this extraordinary fubject, written by Mr. Lewis Morris, a man eminent for his learning and good fenfe. 
Being myfelf unable to add any comment, I thall tranfcribe them verbatim *.

" People who know very little of arts or fciences; or the powers of nature, (which, in other words, are the powers of the author of nature,) will laugh at us Cardiganihire miners, who maintain the exiftence of knockers in mines, a kind of good-natured impalpable people, not to be feen, but heard, and who feem to us to work in the mines; that is to fay, they are the types, or forerumers of working in mines, as dreams are of fome accidents which happen to us. The barometer fails before rain or ftorms. If we did not know the confruction of it, we fhould call it a kind of dream, that foretells rain; but we know it is natural, and produced by natural means, comprehended by us. Now how are we fure, or any body fure, but that our dreams are produced by the fame natural means? There is fome faint refemblance of this in the fenfe of hearing; the bird is killed before we hear the report of the gun. How ever this is, I mun fpeak wcll of the knockers, for they have actually ftood my very good friends, whether they are aërial beings called fpirits, or whether they are a people made of matter, not to be felt by our grofs bodies, as air and fire, and the like.

* They were written to his brother, Mr. William Morris, comptroller to tire Cuftoms at Holyhead. The firft is dated the I t th of October, and the other the th $^{\text {th }}$ December, 1754 . 
"Before the difcovery of Efgair y Mwyn mine, thefe little people, as we call them here, worked hard there day and night; and there are abundance of honett, fober people, who have heard them, and fome perfons who have no notion of them or of mines either; but after the difcovery of the great ore they were heard no more.

"When I began to work at Llwoyn Llwoyd, they worked fo frefh there for a confiderable time, that they frightened fome young workmen out of the work. This was when we were driving levels, and before we had got any ore; but when we came to the ore, they then gave over, and I heard no more talk of them.

"Our old miners are no more concerned at hearing them blafing, boring holes, landing deads, $\& c$. than if they were fome of their own people; and a fingle miner rvill ftay in the work, in the dead of the night, without any man near him, and never think of any fear, or of any harm they will do him. The miners have a notion that the knockers are of their own tribe and profeffion, and are a harmlefs people who mean well. Three or four miners together fhall hear them fometimes, but if the miners ftop to take notice of them, the knockers will alfo ftop; but, let the miners go on at their own work, fuppofe it is boring, the knockers will at the fame time go on as briks as can be in landing, blafing, or beating down the looje; and they are always heard a little diftance from them before they come to the ore. 
" Thefe arc odd affertions, but they are certairily facts, though we cannot, and do not pretend to account for them.-We have now very good ore at Llwyn Llwyd, where the knockers were heard to work, but have now yielded up the place, and are no more heard.-Let who will laugh, we have the grcateft reafon to rejoice, and thank the knockers, or rather God, who fends us thefe notices:"

The fecond letter is as follows:

"I have no time to anfwer your objection againft knockers; I have a large treatife collected on that head, and what Mr. Derham fays is nothing to the purpofe. If founds of voices, whipers, blafts, working, OI' pumping, can be carried oñ a mile underground, they flould always be heard in the fame place, and under the fame advantages, and not once in a month, a year, or two years. Juft before the difcovery of ore latt weck, three men together, in our work of Llwyn Llivyd, were ear-witneffes of knockers pumping, driving a wheel-barrow, \&c.; but there is no pump in the work, nor any mine within lefs than a mile of it, in which there are pumps conftantly going. If they were thefe pumps that they heard, why were they never heard but that once in the fpace of a year? And why are they not now heard? But the pumps make fo little noife, that they cannot be heard in the other end of Efgair $y$ Niwyn mine when they are at work.

"We have a cumb and deaf taylor in this neighbourhood, who has a particular language of his own, 
by figns; and by practice I can underftand him, and make him underftand me pretty well; and I am fure I could make him learn to write, and be underftood by letters very foon, for he can diftinguifh men already by the letters of their names. Now letters are marks to convey ideas, juft after the fame manner as the motions of fingers, hands, eyes, \&c. If this man had really feen ore in the bottom of a fink of water in a mine, and wanted to tell me how to come at it, he would take two fticks like a pump, and would make the motions of a pumper at the very fink where he knew the ore was; and would makè the motions of driving a wheel-barrow: And what I thould infer from thence would be, that I ought to take out the water, and fink, or drive in the place, and wheel the ftuff out. By parity of reafoning, the language of the knockers, by initating the found of pumping, wheeling, \&c. fignifies that we thould take out the water, and drive there. This is the opinion of all old miners, who pretend to underftand the language of the knockers. Our agent and manager, upon the ftrength of this notice, goes on and expects great things. You, and every body that is not convinced of the being of knockers, will laugh at thefe things, for they found like dreams; fo does every dark fcience. Can you make any illiterate man believe that it is polfible to know the diftance of two places by looking at them? Human knowledge is but of fmall extent, its bounds are within our view, we fee nothing beyond thefe; the 
great univerfal creation contains powers, \&c. that we cannot fo much as guefs at. May there not exif beings, and vaft powers, infinitely fmaller than the particles of air, to whom air is as hard a body as a diamond is to us? Why not? There is neither great nor fmall, but by comparifon. Our knockers are fome of thefe powers, the guardians of mines.

"You remember the ftory in Selden's TableTalk, of fir Robert Cotton and others difputing about Mofes's fhoe. Lady Cotton came in, and arked, "Gentlemen, are you fure it is a thoe?" So the firft thing is to convince mankind that there is a fet of creatures, a degree or fo finer than we are, to whom we have given the name of knockers, from the founds we hear in our mines. This is to be - done by a collection of their actions well- attefted; and that is what $I$ have begun to do, and then let every one judge for himfelf."

Thefe letters are curious, though the reafoning is far from conclufive. When I was in the country; I was very defirous of fecing a copy of the remarks on thefe fuppofed aërial fprites, that Mir. Morris refers to in the fecond letter, but was not able to meet with fuch.-In endeavouring to account for the noifes, for we muft believe that fuch noifes have taken place, it has been remarked that they might perhaps have proceeded from the echo of the miners at work, or from the dropping of water in fome hollow places in or near the mine. Thefe conjectures are, however, "very infufficient, if we are to credit Mr. 
Morris's affertion, (and he was a man not likely to make an affertion without being convinced of its truth,) that whilft the miners are engaged in one kind of work, the knockers, as they are called, are carrying on another : while for inftance, as he fays, the miners are boring, the knockers are blafting, the former conjecture muft fall to the ground; and the droppings of water could in no cafe produce an effect that might be miftaken for blafing. I am acquainted with the fubject only from report, but I can affure my readers that I found few people in Wales that did not give full credence to it. The elucidation of thefe extraordinary facts muft be left to thofe perforis who have better opportunities of inquiring into them than I have. I may be permitted to exprefs a hope that the fubject will not be neglected, and that thofe who refide in any neighbourhood where the noifes are heard, will carefully inveltigate their caufe, and, if poffible, give to the world a more accurate account of them than the prefent.-In the year 1799, they were heard in fome mines in the parifh of Llanvihangel Y fgeiviog, in Anglefea, where they continued, at intervals, for fome weeks.

The lower clafs of the Wellh yet continue to believe in the exiftence of witches. Many old women, therefore, only becaufe they happen to be old, and perhaps deformed, have to bear the odium of preventing the cows from yielding milk, and butter 
from forming in the churn. They are alfo believed to poffefs the power of inflicting diforders both on men and cattle, and that they feldom neglect to do it when they have been offended. This will well account for the notion of witches having been ftrenuouly maintained fome centuries ago even by the moft enlightened perfons of the age. Old women, on whom the generally odious epithet of witch has been once fixed by the popular voice, have found it their intereft, and in Wales to this day find it their intereft, to deny nothing that is alleged to them. They become thus held in fuperftitious fear by the people, and in many inftances obtain an eafy livelihood from their fuppofed extent of power. Whereever they ank alms, it would be (fay the common people) the death of a cow or horfe, or perhaps even of one of the family, to refufe them; and the neighbouring pafantry, much as they hold them in deteftation, believe it their own intereft to keep then always in good humour. The old women thus live, in fome meafure, in affluence, with little other trouble than feeding and training up three or four cats, and at. tending minutely to the concerns of their neighbours.

On the eve of All Saints, the Welfh people, as foon as it is dark, kindle great fires near their houfes, which they call coelcerth, or bonfires. This cuftom has been fuppofed, though probably without any foundation, to have originated with the druids, and to have been intended by them as an 
offering of thankfgiving for the fruits of the harveft. Sometimes fifty or a hundred of thefe fires may be feen at once, and round each the people dance, hand in hand, at the fame time finging and fhouting in the moft riotous and frantic manner imaginable. In many places a cuftom is retained of each perfon throwing a few nuts into the flame, by which they pretend to foretell the good or ill fortune that will attend them during the enfuing year. If, by the expanfion of air within them, the nuts burft, they immediately conclude that they are doomed to die within twelve months. - On the day after All Saints the poor children go about the towns and villages to beg bread and cheefe.

On the eve of St. John the Baptift, they place little bundles of the plant called St. John's wort over their doors, or windows. Thefe they believe will purify their houfes, and drive away all fiend. $s$ and evil fpirits. The druids had a cuftom fimilar to this, in which they ufed fprigs of vervain.

The young people have many pretended modes of declaring their future lovers. Moft of thefe are, however, common to the peafantry of our own country, which renders it needlefs to repeat them here.

I have been informed that a diforder fomewhat refembling, St. Anthony's fire, which the Welfh people call $1 r$ Eryr, the eagle, is fuppofed to be at 
any time cured by the following kind of charm. A perfon, whofe grandfather, or great grandfather, has eaten the fleth of an eagle, is to fpit on the part affected, and rub it for a little while with his fingers. 'This is efteemed an infallible remedy. A maid-fervant of a gentleman of my acquaintance who refides in Caernarvonfhire, declared, in my hearing, that the had been cured of this complaint by an old man whofe grandfather had eaten of an eagle. She faid that he at the fame time ufed fome words, to aid the charm, which the could not comprehend.

It is an opinion very prevalent within the diocefe of St. David's in Pembrokefhire, that a fhort time previous to the death of a perfon, a light is fometimes feen to proceed from the houfe, and even from the bed, and to purfue its way to the church where the body is to be interred, precifely in the fame track that the funeral will afterwards follow. This light is call canwyll corph, or " the corpfe candle."

A Atrange cuftom prevails in fome obfcure parts of North Wales, which, however, the clergy have now almoft abolifhed. This is termed the "offering of an enemy." When a perfon fuppofes himfelf highly injured by any one, he repairs to fome church dedicated to a celebrated faint, or one who is believed to have great power over the affairs of men; here krieeling on his bare knees before the altar, and offering a piece of money to the faint, he utters 
the moft virulent and dreadful imprecations, calling down curfes and misfortunes on the offender and his family even for generations to come. Sometimes the offended perfons repair for the fame purpofe to fome facred well, dedicated to a faint. Mr. Pennant was threatened by a man, who fancied he had been injured by him, " with the vengeance of St. Elian, and a journey to his well, to curfe him with effect *."

Some of thefe wells are held in great repute for the cure of difeafes; and the faints are alfo occafionally applied to for the recovery of ftolen goods. -In the parifh of Abergeley, in Caernarvonhire, there was formerly a well dedicated to St. George, who was the Welih tutelary faint of horfes. All thefe animals that were diftempered were brought to the well, fprinkled with water, and received this bleffing: Rbad Duw a Saint Siors arnat, "the bleffing of God and St. George be on thee." It was the cultom for thofe who kept a great number of horfes, at certain times to make an offering of one of them to the faint, in order to fecure his bleffing on all the reft.-If a well of any faint was near the church, the water for baptifm was always fetched from thence; and, after the ceremony, the old women would frequently wath their eyes in the water of the font.

- Tour in Wales, ii. 337. 
Some years ago it was a cuftom in the churches of North Wales, whenever the name of the Devil occurred, for every one of the congregation to fpit upon the floor. This was done to fhew their contempt of the evil fpirit. Whenever the name of Judas was mentioned, they expreffed their abhorrence of him by friking their breafts.

On the morning of Chrifmas day, about three o'clock, the inhabitants ufed formerly to affemble in the churches; and, after the prayers and fermon were concluded, they continued there finging pfalms and hymns with great devotion till daylight. Thofe who through age or infirmity were difabled from attending the church, invariably read the prayers in their own houfes, and fang the appropriate hymns. This act of devotion was called plygain, " the crowing of the cock*." It has been a general belief among the fuperftitious, that inftantly

\section{At lis warning,}

Whether in fea, or fire, in earth, or air,

'Th' extravagant and erring fuirit hies

'To his confine.

But, during this holy feafon, the cock was fuppofed to exert his power throughout the night:

Some fay, that ever 'gainft that feafon comes

Wherein our Savour's birth is cclebrated,

The bird of dawning lingeth all night long:

And then, they fay, no fpirit walks abroad;

* Pennant, ii. 340 : 
The nights are wholefome; then no planets frike;

No fairy takes; no witch hath power to charm:

So hallow'd and fo gracious is the time.

The Wellh yet retain the cuftom of wearing leeks in their hats on St. David's day. On the firft of March 640 , the Wellh forces under command of king Cadwallo obtained a fignal victory over the Saxons. The battle happened near a large piece of ground in which this vegetable was cultivated, and the foldiers put leeks into their hats in order to diftinguifh themfelves. Since this period the leek has been retained as a badge of honour. "s The Welfhmen (fays Fluelin to Henry V.) did goot fervice in a garden where leeks did grow, wearing leeks in their Monmouth caps; which, your majefty knows, to this hour is an honorable padge of the fervice *."

The middle and lower claffes of the people were formerly much addicted to tcrming, that is, brewing a barrel of ale at fome favourite ale-houfe, and ftaying there till it was all drunk out. They never went to bed, though the term fhould even laft a whole week. They flept in their chairs, or on the floor, as it happened, and the moment they awoke they renewed their jollity. At length, when the barrel was exhauted, they reeled away home. The hero of this Bacchanalian rout always carried off the fpiggot in triumph.

* Shakfpere's Henry V., act iv. 
The peafantry of part of Caernarvonthire, Anglefea, and Merionethfhire, adopt a mode of court/.bip, which till within the laft few years was farcely eiven heard of in England. It is the fame that is common in many parts of America, and termed by the inhabiants of that continent bundling. The lover fteals, under the fhadow of the night, to the bed of his fair one, into which (retaining an effential part of his drefs) he is admitted without any fhynefs or referve. Saturday or Sinday nights are the princi. pal times when this courthip takes place, and on thefe nights the $m s_{\star n}$ fometimes walk from a diftance of ten miles or. more to vifit thetr favourite dam. fels. - This ftr. ange cuftom feems to have originated in the farc" "ty of fuel, and in the confequent unpleafantnefs 0 , $f$ fitting together, in the colder parts of the year, vithout a fire. Much tias been faid of the innor ence with which thefe meetings are conducted. Thi ${ }^{\prime} s$ may be the cafe in fome infances, but it is a very common thing for the confequence of the intercourfe to make its appearance in the world within two or three months after the marriage cere. mony has taken place. The fubject excites no particular attention among the neighbours, provided the marriage be made good before the living witnefs is brought to light.- Since this cuftom is entirely confined to the labouring claffes of the community, it is not fo pregnant with danger as on a firt fuppofition it might feem. Both parties are fo poor, that they are neceffarily conftrained to render their s

iflue 
iffue legitimate, in order to fecure their reputation, and with it a mode of obtaining a livelihood.

Their weddings are ufually attended by all the neighbours, fometimes to the number of thirty or upwards. After the ceremony, the day is dedicated to feftivity, and is chiefly fpent in drinking and finging. At a wedding in the little village of Llanberis, I obferved in the church as many as twenty or fiveand-twenty attendants. A collection is made on their return to the houfe to defray the expences of the occafion, to which of courfe every one contributes. A good idea of the reit of the bufinefs may be collected from a pleafant account of a wedding-feaft in Cwm y Clo, near Llanberis :

A fire of fquare peat, and fufficiently dricd, TVas fpread on the hearth, and at leaft four feet wide;

Over which took their ftation fix kettles or more, Which promifed a feaft, when they opened their ftore; And round this flat furnace, to keep them quite hot, Were plac'd twelve more veffels, which held-God knows what. Four cooks, in fhort bed-gowns, attend by defire, Like the witches in Macbeth, to Atir up the fire.

Forty trenchers, with dull knives, and forks made no brighter, Were fpread on fome napkins, which once had been whiter, Supported by planks, forty feet long, or more, Completely were rais'd on the grafs out of door. But here we are bound the word table to offer, 'That our verfes' great diguity never may fuffer. The table prepar'd, and the cooking completed, 'Twas perfectly needful the gueits hould be feated. Loofe boards werc ere cted on ftones with great art; But proving too hard for a certain broad part, 
A number of cufhions were inftantly made,

But not with a needle $\rightarrow$ no; formed with a fpade.

The fineft of ling, root and branch, from the common,

Par'd off, prov'd a cuihion for man and for woman.

Now folks, male and femaic, came in by whole dozens, Of neighbours, acquaintance, of friends, and of coufins.

It excited furprize, from a region of rocks, That orderly people thu uird iffue by flocks.

Black ftockings, bidc cloaks, and men's bats, all admire, Which appear'd to be every female's attire.

Wiste many a longing eye glanc'd at the board, The word dinner founded-acceptable word!

Five butts of boil'd beef of a gigantic fize,

On the board took their ftation, with joy and furprize;

On thefe clofe attended, as guards rang ${ }^{2} d$ for pleafure, As many mafh'd peas as would heap a ftrike meafure; With cabbage a pyramid, much like a tteeple:

All thefe were furrounded with-thirty-eight people.

'The moment arriving when dinner was o'er, The places were taken by thirty-eight more; And then a third fer, nearly equal to thefe, Sat down to the cabbage, the beef, and the peas; Befides about fifty remaining behind,

Who ftuck to the tankard, for none of them din'd.

And now an old difh open'd wide at each finner, A's if it would fay-" Pay a thilling for dinner."

Eight ftrike of brown malt, which Cacrnarvon had feen, And colt the bride's father two pounds and fourteen, Was brew'd into drink, that would make one man mad, But given a fecond would make his heart glad. Each quart brought back fixpence, and that pretty foon, Iis cot was a public-houfe that afternoon. 
The glafs going round-no - the mug I would fay,

The lads and the laffes began to look gay, To fmile on each other, to toy and to joke;

I was an obferver, but not a word fpoke.

The bard, in a rapture, his harp handled foon, And twang'd with his fingets, to try if in tune; The people felected and pairing began, Each lafs was indulg'd with the choice of her man; Than Anazons more than like fairies were fecn, Full thirty gay couple to dance on the green.

Joy held his firm ftation till morning was come ; When each fwain had the plearure to lead his nymph home.

In South Wales, previous to the wedarings of the peafantry, a herald with a crook or wand, adorned with ribands, fometimes makes the circuit of the neighbourhood, and proclaims his bidding, or invitation, in a prefcribed form; but the knight-errant cavalcade on horfeback, - the carrying off the bride, -the refcue,-the wordy war in rhyme between the parties, which once formed a fingular fpectacle of mock conteft at the celebration of nuptials, is now almoft, if not altogether laid afide, throughout erery part of the principality .

The funerals are attended by greater crowds of people than even their weddings. In the funeral that I attended at Llanberis, which has been de. fcribed in the preceding volumet, there were at leaft a hundred attendants. - A cuftom prevails in

* Cam. Reg. rol. ii. 
this country of each individual of the congrega tion making fome offering in money on thefe occafions, which, if done in the church, is paid as a mark of refpect to the clergyman. This cuftom, which is at prefent confined to North Wales, has doubtlefs been retained from the Romifh religion, where the money was intended as a recompence to the priefts for their trouble in finging mafs for the foul of the deceafed. In fome cafes, where the clergyman is not refpected by his parifhioners, the offerings are made on the coffin at the door of the houfe where the deceafed refided, and are diftributed amongft the poor relatives. When, however, the offerings are made in the church, and the other mode very rarely occurs. The whole of the morning or evening prayers for the day, and the ufual part of the burial fervice in the church, are firft read: the next of kin to the deceafed then comes forward to the altar table, and if it is a poor perfon, puts down fixpence or a fhilling, but if he is fufficiently opulent, half a crown or a crown, and fometimes even fo much as a guinea. This example is followed by the other relatives, and afterwards by the reft of the congregation whofe fituation in life will afford it, who advance in turns, and offer. When the offering of filver is ended, a Mort paufe enfues, after which, thofe who cannot fpare any larger fum, come forward, and put down each a penny (a half-penny not being almitted). Collections on thefe occafions have been known to amount to ten or fifteen pounds, but where the re- 
latives are indigent, they do not often exceed three or four hillings. In cafes where families are left in diftrefs, this money is ufually given by the clergyman to them. When the collection is entirely finifhed, the body is taken to the grave, the remainder of the burial-fervice is read, and the awful ceremony is there clofed.-The offerings at Llanbublic, the parifh church of Caernarvon, fometimes amount to fifty or fixty pounds a year.

It is ufual in feveral parts of North Wales, for the neareft female relation to the deceaied, be the widow, mother, fifter, or daughter, to pay fome-poor perfon, of the fame fex, and nearly of the fame age with the deceafed, for procuring llips of yew, box, and other evergreens, to ftrew over and ornament the grave for fome weeks after interment; and in fome inftances for weeding and adorning it, on the eves of Eafter, Whitfuntide, and the other great feftivals, for a year or two afterwards. This gift is called Diodlys, and it is made on a plate at the door of the houfe, where at the fame time the body is ftanding on a bier. It had its name from the cuftom, which is now difcontinued, of the female relative giving to the perfon a piece of cheefe with the money ftuck in it, fome white bread, and afterwards a cup of ale.-When this previous ceremony is over, the clergyman, or, in his abfence, the parifh clerk, repeats the Lord's prayer; after which they proceed with the body to the church. Four of the next of kin take the bier upon their fhoulders; a cuftom 
which is confidered as expreflive of the higheft mark that even filial piety can pay to the deceafed. If the diftance from the houfe to the church be confiderable, they are relieved by fome of the congreoration; but they always take it again before they arrive at the church.-I have been informed that in fome parts of the country it is ufual to fet the bier down at every crofs-way, and again when they enter the church-yard, and at each of thefe places to repeat the Lord's prayer.

In fome parts of Wales it was formerly cuftomary. for the friends of the dead to kneel on the grave, and there to fay the Lord's prayer for feveral Sun. days fubfequent to the interment, and then to drefs the grave with flowers.-It was alfo reckoned fortu. nate for the deceafed if a thower of rain came on while they were carrying the body to church, that his coffin' might be moiftened with the tears of heaven.

I have obferved that in moft parts of North Wales, the fame practice prevails which is common in England, of crowding all the bodies into that part of the church-yard which is fouth of the church. The only reafon that I have heard the Wellh people give for this cuftom is, that the north is the rurong fide. The true reafon, however, is, that formerly it was cuftomary for perfons, on entering a churchyard, and feeing the grave of a friend or acquaintance, to put up to heaven a prayer for the peace of their foul; and fince the cntrances to churches were 
ufually either on the weit or fouth fide, thofe perfons who were interred on the north efcaped the common notice of their friends, and thereby loft the benefit of their prayers. Thus the north fide becoming a kind of refufe fpot, only patipers, Aillborn infants, or perfons guilty of fome crime, were buried there*.

In Mr. Pratt's Gleanings through Wales I obferve a charmingly animated defcription of the neatnefs and elegance of the Welh church-yards, and of the attention that is beftowed by the furviving selatives, to the graves of their kindred: but I am forry to fay, if this gentleman has ftated facts, that the cuftom is not general, as he has afferted; it muft be completely local. During the feren months that I fpent in vifiting and examining North Wales, I never faw, nor could I ever hear, of an inftance of the graves being weeded every Saturday; "of their. being every week planted with the choiceft flowers of the feafon," or that, if a nettle or weed were feen on the Sunday morning, the living party to whom the grave balonged, "would be hooted, after divine fervice, by the whole congregation."

* Groets Clio, 222 . 


\section{( 290$)$}

\section{H A P. XXIV.}

\section{Essay on the Origin and Character or THE WELSH LANGUAGE* .}

The Charager of the Ianisuag. - Of the Poetry. - Other Languages Dia'cess of the Welp. - Analogy betwixt the Hebrew and Welfs. Betwixt the Greck and Welfh. - The $W$ elp Letters, and their Force.-Lif and Explanation of feveral of the primitive W'ords. - Lif of Weifu Words in common Ufe. - The Saxon Alphabct moft probably belonging to the WI elfh. - Prefent Sitate of the Welfe Langrage.

THE Welfh is a rich and copious language, which (however harfin and unpleafant it may found to forejgn ears) has numerous elegancies, and many beautiful forms of exprefion. Its copiounnefs is without rival, principally arifing from the various combina-

* For the principal part of this effay, (which is intended only for the intruetson of the Englin traveller, ) I am indebted to the following works:--Commentarioli Britannize defcriptionis fragmentum, auftore HumfredoLhwyd; - Powel's Hittory of Wales; -Edward Lhwyd's Netes in Gibfon's Camden;-Rowland's Mona Antiqua rctaurata; -Owe!s's Tranflation of the Elegiea of Llywarch Hên;-Owen's Welfin Dictionary;-Jones's Relics of the Weln Dards;-the Monthly Magazine;-and the Cambrian Regifter, rols. i. anl ii. I have alfo to acknowledge, in addition to the above authorities, the correfpondence and corrections of $\mathrm{my}$ valuable friend, the reverend Ftter Williams of Llamîng, in Caemarwonthire. 
tions of its verbs. Each of thefe has about twenty modifications, by means of qualifying prefixes; and in cvery form they can each be conjugated, either by inflexions like the Latin, or by auxiliaries, as in the Englifh language. The author of Letters from Snowdon has juftly remarked, that the Welfh languagre, at the fame time that it boafts " the foftnefs and harmony of the Italian, has all the majefty and expreffion of the Greek." Of this I fhall tranfcribe two fingular inftances: the one in an englyn, or kind of epigram, on the Silk-Worm, compofed entirely of vowels; and the other in a diftich on Thunder, the grandeur of which is fcarcely furpaffed in any language :

O'i wiw $\hat{w} y$ i weu ê â, a'i weuau

O’i wyan y weua;

E' weua ei we aia',

A'i, weuau yw ièuau iâ.

I perih by my art;

Dirg my own grave:

I fpin my thread of life;

My death I weave.

Tân a dî̀r yn ymwriaw,

Yw'

The roaring thunder, dreadful in its ire,

Its water warring with aëi ial fire*.

The metre of the poetry is very artificial and alliterative. The language abounds with confonants

* Jones's Welf Bards.

U 2 
and monofyllables, which, as they are incompatible with quantity, the bards were not able to reduce into concord by any other means than by placing its harther confonants at fuch intervals, fo intermixing them with the vorvels, and fo adapting, repeating; and dividing the feveral founds, as to produce an agreeable effect from their fructure. To the ears of the natives the Welin metre is extremely pleafing ; and it does not fubject the bard to more reftraint than the different forts of feet occafioned to the Greek and Roman poets. The laws of alliteration were prefcribed and obferved with fuch fcrupulous exactnels, that for many centuries a line, not perfectly alliterative, was condemned as much by the Welh grammarians, as a falfe quantity was by the Greeks or Romans.

The Weln, the Cornifh, and the Armoric * land guages, agree in their grammar, fructure, and nomenclature; and the Irifh, and Erfe or Gaelic, are fundamentally the fame with the Welh, though they differ much, in confequence of the long feparation of the inhabitints, in dialect and pronunciation. They all proceeded from one common fource, the ancient Celtic, or Britih tongue.

* Armorica, or Bretarne, in France, was colonized by the Britons about the year 34 . Its name is properly' Ar y-môr-ucha," "On the upper Sea." The natives of Cornwall began to lof " their ancient language in the reign of queen Elizabeth. I believe the latter is uow extinet.

There 
There is alfo a very ftriking analogy betwixt the Hebrew and the Wellh languages. The primitive and derivative words have, in many inftances (allow. ing for the different modes of pronunciation) fo exact a refemblance, that it is evident feveral of the Welfh words muft have had their origin in this, the moft ancient language of mankind. Even the Welfh now fpoken has more founds agreeing with the Hebrew, than with all the other languages together. The following are infances of their agreement in fingle words:

\begin{tabular}{lll} 
Hebrew. & Welfh. & \multicolumn{1}{c}{ Englif. } \\
Bagad & Bag’d & A great many. \\
Bareh & Bara & Meat or victuals. \\
Cir & Caer & A fortified place. \\
Cis & Cift * & A cheft. \\
Denah & Dyna & This or that. \\
Gad & Câd & An army. \\
Gadah & Gadiaw & To pafs by. \\
Gavel & Gafaelt & Tenure, or lands bounded. \\
Geven & Cefyn & A ridge, or back. \\
Hanes & Hanes & To fignify, or account. \\
Jiffal & Ifel, or Ifelu & To throw down. \\
Mah? & Mae? & What? where? how? \\
Maguur & Magwyr & A habitation, or dwelling. \\
Malas & Melys & Stwcet, or to fweeten. \\
Mar & Maer & A lord. \\
Me-ab & Mâb & A fon. \\
Mohal & Mcel & A hill.
\end{tabular}

* The word kift for cheit, ufed in many parts of Yorkthire, may have had its origin in this Britith word.

+ Hence the peculiar tenure called Gavelkind. 
294 ESSAY ON THE ORIGIN AND CHARAC'TEK

\begin{tabular}{lll} 
Hebrez. & We'js. & \multicolumn{1}{c}{ Engli/b. } \\
Nadu & Nadu & Thiy moan, or lament. \\
Nafe & Nef & Joyful. \\
Path & Pcth & A part, or portion. \\
Reith & Rhith & Appearance. \\
Sac & Sich & A fack. \\
Sethar & Sathru & To throw under the fees.
\end{tabular}

But it is not in fingle words merely that the Welfir and Hebrew languages agree: they are likewife fo nearly allied in their grammatical forms, that it would be difficult to adduce even a fingle article from the Hebrew which is not alfo to be found in the Welfingrammar: and there are many whole fentences to be found in both languages which in the words are exady alike:

Hebrew. Byllang ad anicth cal neoth Jangeob. Welfh. By-llwng adon-ydh holl neuodh Jago. Englifh. The lord hẳs firallowed up all the tabcrnacles of Jacob.

Hebrezu. Derech bethah iitsengad,

Welfh. Dyrac buth-hi ai-i-fengyd.

I. The road of her houfe lie would tread.

2. The avenue of her dwelling he would go to tread.

Hebrezu. Me huaze malec hacâvodh Jehovah títhâoth hua malẹ hacâvodh. Selah!

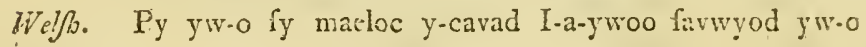
maeloc y-cavad. Sela!

s. Who is the king of Clory? The Lord of Hofts, he is the king of Glory. Selah?

2. Who is he that is poffefior of attainment? "I that ami be of hofs,", he is poffeffor of attáinment? Behold *.

* Literal tranflation.

Hebreac, 
Hebrew. Mageni ngal elöim.

IVel乃. Meigen-i hwyl elyv.

1. My fhield is from God.

2. My protection is from the Intelligences.

Befides this fingular conformity in the Hebrew and Welfh languages, the latter has alfo in many refpects a near refemblance to the Greek. Many of the words that have the fame fignification, have the fame, or nearly the fame, found in each. Their articles, pronouns, prepofitions, and affixes, are frequently alike. The verbs generally agree in the form of their inflexions, and often in the identity of found. It is conjectured that with more than half the words contained in Parkhurf's Lexicon, there are words in the Welh language that have the fame found and fignification. The following are a few of the inftances:

Greek.

A $\omega$

$\Delta \alpha x p v$

$\Delta$ oxpuw

$\Delta x \sigma x \omega$

$\Delta v \delta \alpha \sigma \times \omega$

$\Delta$ ขw

$\Delta n$

$\Delta$ evpew

$\Sigma \lambda \Sigma: \omega$

F. $\mu .6$

$\mathrm{F} \xi_{\mathrm{W}}$

Iva

s. $\alpha \div \alpha$
Welp.

Aru

Dagyr, deigyr

Dagru, deigio, and dcigraw

Dyfcu, from dyfc, learning

Dydd?cu

Deuo

De

Dyre

Aelu, aclëu, eulïu

Imi

Echw, uchw

Ina

Kyd, kyda

\section{Englifs.}

To plow.

A tear.

To hed tears.

To tcach.

To teach, to inftrues.

To come.

Truly, in truth.

Hither.

To pity.

T'o ine.

Out, without.

That, to the end that

$\left\{\begin{array}{l}\text { Againft, along, by reafon } \\ \text { of. }\end{array}\right.$ 
Cinok. li, ils.

Axo; Lios, Lisus

Masaww Merwino

Min $\mathrm{Mo}$

$\mathrm{N}_{2} \xi \quad \mathrm{Nês}$

$N(i b, v i \quad \mathrm{Ni}$, nyni

Naw, wa Nyein, "ijn

O) $\omega$ Oio

Fuxs 'Raca
Einglifis.

$\left\{\begin{array}{l}\text { A people, a number of } \\ \text { nen, a muititude. }\end{array}\right.$ 'l'o carife to decay. I, flt, that not, nut Night.

Wh, us iwo.

Of us (wo).

"iv thisk, or tear in mind. A rake.

It the Wein language had its origin in the Hebrew, of which, all circumitances confidered, there can be little doubt, this analogy betwixt the TVelfh and Greek is oilly wirat night be expected.

The ancient TTelfin innuícipts contain as many as thirty-eight different letters, ol characters. Thefe, fince the invention of printing, and the confequent introduction of the Roman letters, have necefiarily been reduced in number. Two, and even three letters, are now, in fome inflances, adopted to exprefs what had before a fingle appropriate character. -The uncompounded letters are $A, B, C, D, E$, $\mathrm{F}, \mathrm{G}, \mathrm{H}, \mathrm{I}, \mathrm{L}, \mathrm{M}, \mathrm{N}, \mathrm{O}, \mathrm{P}, \mathrm{R}, \mathrm{S} ; \mathrm{T}, \mathrm{U}, \mathrm{W}$, and $\mathrm{Y}$ : the compounds are, Ch, Dd, Ff, IVg, Ll, Ph, and Th. The rowels are fometimes lengthened by an accent, marked thus, $\hat{a}, \hat{e}, \hat{i}, \hat{o}, \hat{u}, \hat{w}^{*}$.

* $\mathrm{V}$ is fometimes ufed inflead of $\mathrm{F}: \mathrm{B}$ and $\mathrm{P}, \mathrm{C}$ and $\mathrm{G}, \mathrm{U}$ and $\mathrm{Y}$, are alfo occafionally ufed for each other; as were alfo formerly $\mathrm{V}$ and $\mathrm{M}$. 
The following is an account of thofe letters that, in their powers, differ from fimilar ones in the, Englifh language :

A has only the found of our open $a$ in the word lard: as cafeell, a caftle.

C, invariably, is hard, as the Englifh $k$ : thus cader, a fort, is pronounced kader. C joined with $\mathrm{w}$, and having a vowel fucceeding, fupplies the place of our $\mathrm{Qu}$.

$\mathrm{Ch}$ (marked ç in Mr. Owen's Welh Diktionary) is a guttural, of the fame power as the Greek $\chi$.

$D d$, or, as it is fometimes written, $d h$, is an afpirated $d$. It has wearly the found of $t b$ in the word $t$ bis: $d l d a$, good, is pronounced tha.

F has the found of our $v$ : thus fclen, yellow, is pronounced volen.

Ff fupplies the place of orir fingle $f$.

$\mathrm{G}$ is invariably hard, as the $g$ in gain.

I has the fame found as it has in the Italian language, of $e e$, as in our word feen: thus cill', a retreat, is pronouncer keel.

Ll is an afpirated $l$, having much the found of $t b l$ : thus llan, a church or village, is pronounced much like tblan.

$R$, when it begins a word, is always afpirated.

$\mathrm{U}$ has the found of $i$ in the word fin: thus pump, five, is pronounced pimp.

WW is a vowel, and has the power of our oo in foon : thus rbizv, an afcent, is pronounced rbioo.

$Y$, in fome words, has the found of the Englifh $i$ in fint thus fymon, a well, is pronounced finnon. It has alfo fometimes the found of 0 in the word boney; and fometimes of $z$ in mutdo 
Primitive Words that frequently occur in the Names

$$
\text { of Places, Eंc. }
$$

Aber, a confluence; the fall of a leffer water into a greater, as of a brook into a river, or a river into the fea : thus Aberdovey fignifies the place where the Dovey juins the fea.

Avon, what fows; and thence a ftream or river. The river Marvddach, near Barmouth, is ufually called Avou varur, sthe great river.'

Allt, a cliff, the feep of a hill. Penall, 'the head of the fteep,' near Machynlletl.

Ar, upon, bordering or joining upon. Harlech, 'on the cliff,' in Merionethmire.

Each, and bychan, little: the feminine genders are vacb and vychan, or vichan. Glyder bach, "the little Glycier,' a mountain near Llanberis.

Bód, a dwelling or ftation. Bôdeiniol, 'the dwelling of Daniel." Bron, the breaft: feminine fron. Cader Fronwen, "the mountain of Fronwen,' or 'the white breait,' is one of the Berwyn mountains.

Bryn, a hill. Bryn y Croes, 'the hill of the crofs.'

Bwolch, a gap or pafs betwixt rocks or mountains.

Cader, a fortrefs, or ftrong hold; fometimes a feat, or place, of obfervation.

Cacr, a fortified place, ufually conftructed with ftones and mortar; thus diftinguifhed from Dinas, which generally implied a rampart of loofe ftones and earth.

Caffell, a caftle. Cafiell Dolbadarn, 'Dolbadarn caftle.'

Cefyn, the back; a ridge. Cefyn Creini, "the rock, or mountain of worfhip,' near Corwen.

Carncll, a heap of ftoncs, a huge rock. Carnedd Llewelyn, 'I.lewelyn's mountain.'

$\mathrm{Cil}$, a retreat. Llan $y \mathrm{Cil}$, " the church in the retreat near Bala.' 
Clawd, a dike; fometimes a fence, wall, or ridge. Clazud Offa, 'Offa's dike,' and Clazucl cocl,, 'the red ridge,' a part of Suowdon.

Clogwyn, a precipice. Clogwyn du'r Arda'u, 'the black pre: cipice,' part of Snowdon.

Coed, a wood. Coed Euloe, 'Euloce wood,' near Hawarden, in Flint thire.

Cors, a marh, or bog: the word, in its ufual acceptation, fignifies 'refds.' Cors y Gafjeg, 'the mare's bog,' in Denbigh. Shire.

Craig, a rock. Craig Eslwyleg, 'the eagle's rock,' near Llangollen. From this word the Englifh crag, of the fame fignitication, is derived.

Cruia, a great hollow, or glen. Crum 'Idruel, " the hollow of Idwel,' near Llanberis.

Dinas, a fort, or fortified place, confructed in general with a rampart of loofe ftones and earth, without any cement.

Dôl, a meadow, or dale, in the bend of a river.

Draus, a door, pafs, or opening. Drws Ardudwy, 'the pass of Ardudwy,' near Harlech, Merioneth hire.

Dü, black. Cefynd du, 'the black ridge,' betwixt Caernarvon and Srowdon.

$D_{y}$ fryn, a wide cultivated valley. $D_{y}$ fryn Clwyd, the vale of Clwyd.'

Ffymon, though generally fignifying a fpring or well, is fometimes ufed for the fmall lakes on the higheft parts of the mountains; as Fymmon frech, 'the fpotted pool,' Ffynnon felen, 'the yeilow pool,' \&c. near Llanberis.

Gurth, a mountain that bends round, or that inclofes.

Glan, a bank, or fhore: in compofition lan, as Rhyddlan, "the red hore,' Flinthire.

Glyn, a deep vale, through which a river runs; a glen, Pont y Clyn, 'the bridge of the glen,' near Corwen.

Gwern, a watery meadow. Ga'ern Einion, 'Eirion's meadow, a farm not far from Harlech.

Guyydd, a wood, wody, or wild. 
Groyn, white: feminine grven.

Goch, or coch, red.、Clawdil coch, ' the red ridge,' a part of Snowdon.

Llan, a fmooth plot, a place of meeting, the church-place or village, and, figuratively, the church.

Llech, a flat ftone, or crag, a fmooth cliff. Harlech, 'upon the cliff' in Merionethfhire.

Llwyn, a grove, or copfe. Llwyn on, 'the ah grove.'

Llyn, a pool, pond, or mere: plural Llyniau.

Maen, a ftone. Maentrurog, ' the ftone of Twrog,' a church in the vale of Ffeftiniog.

Maes, an open field. Maes Porth, 'the field of the port,' in Anglefea, nearly oppofite to Caernarvon.

Mawr, great: feminine vawur. Mynydd mawr, "the great mountain,' betwixt Caernarvon and Beddgelert.

'Morfa, a marfh. Morfa Rbyddlan, 'Rhyddlan marfh', FlintThire.

Mynydd, a. mountain. Mynydd mawr, ' the great mountain.'

Nani, a narrow hollow, or ravine. Nant Frangon, 'the beaver's hollow, near Bangor.

Pen, a head, top, or end. Penrbyn, 'the head of the promontory,' near Bangor.

Pifyll, a narrow ftream, or fpout of water. Pifyll $y$ Gain, 'the fpout of the Cain,' near Dolgelle.

Plâs, a hall, or manfion. Plâs Nervydd, 'the new manfion,' in Anglefea, near Moel y Don ferry.

Pont, a bridge. Pont Seiont, "the bridge over the Seiont," near Caernarvon.

Porth, a port, or harbour. Porth yn Llyn, " the harbour in the promontory of Llyn.

Rbaicidr, a cataract. Rbaicdr mawr, 'the great cataract,' neat' Aber, Caernarvonihire.

Rbiw, an afcent. Rbiwedog, 'the abrupt afcent,' near Bala. Rhôs, a moift plain, or meadow. Penrlsos, "the head of the plain,' a village in Anglefca. 
Rbyn, a nofe, generally ufed with the word $P_{c n}$, and then fignifying a promontory.

Rbyd, a ford, ' Rbyd Elen, 'Helen's ford.'

Sarn, a caufeway. Trum y Sarn, 'the caufeway of the ridge,' not far from Bala.

Tal, the front, head, or end. Tal y Llyn, 'the head of the pool,' near Cader Idris, Merionethlhire.

Traeth, a fand on the fea-fhore. Traeth mawr, near Beddgelert; Caernarvonhire.

Fref, or Tre, a town or townhip. Trefdraeth, "the town on the fand,' near Newborongh, Anglefea.

Ty, a houfe. Ty dì, ' the black houfe,' a farm betwixt Cacrnarvon and Ilanberis.

rnys, an ifland. Ynys Seiviol, 'Seriol's ifland,' or Prieftholme ifland, off the cont of Anglefea.

Welp Tords in common Ufe.

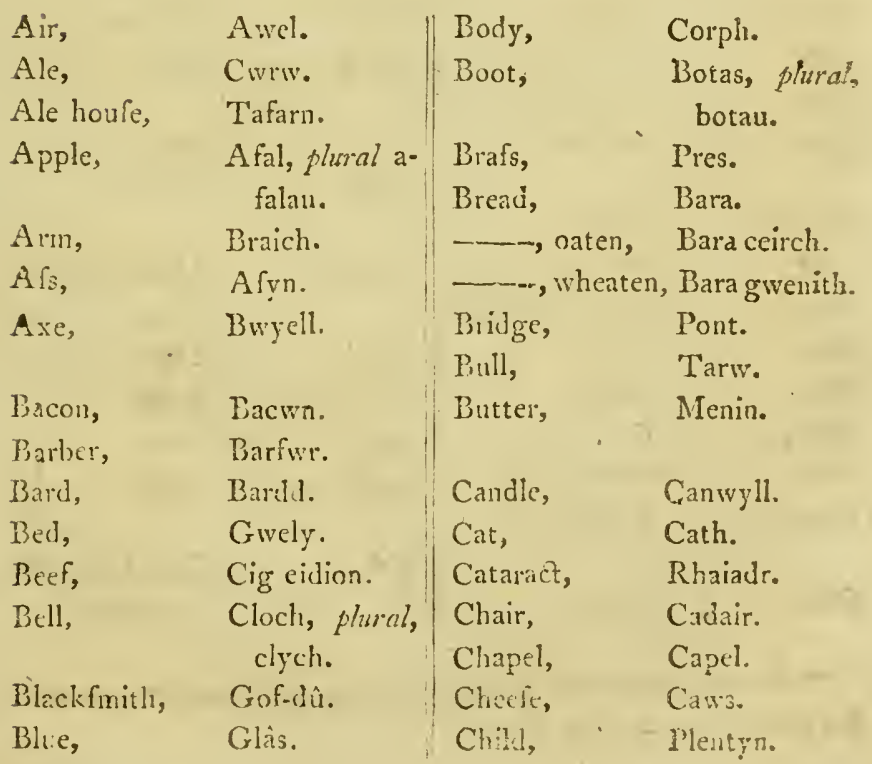




\section{ESSAY ON THE ORIGIN AND CHIARCTETC}

\begin{tabular}{|c|c|c|c|}
\hline Church; & Llan, eglwys. & Goofe, & Givydd. \\
\hline Coal, & Glo. & Grave, & Bedd. \\
\hline Coalt, & Glan, y-mốr. & Gun, & Gwn. \\
\hline Cook, & Cog. & Guide, & Fforddwr: \\
\hline Cow, & & & \\
\hline & gwarthieg. & Hand; & Llaw. \\
\hline Crean, & Hufen. & Harp, & T'elyn. \\
\hline Croes, & Croes: & Harper; & Telynwr. \\
\hline Crow, & Brân. & Hat, & Het. \\
\hline Cup, & Cwpan. & Head, & Pen. \\
\hline & & Heath & Grûg. \\
\hline Dinner; & Ciniaw * & Hedge; & Cae. \\
\hline Difn. & Difgyl. & Hill, & Bryn. \\
\hline Doctor, & Meddyg. & Hog, & Mochyn. \\
\hline Dog, & Ci, pl. cwn. & Horfe; & Ceffyl. \\
\hline Door, & Drivs. & Houfe, & Ty, pl. tai. \\
\hline Drink, & Diawd. & & \\
\hline & & Inni,. & Tafarn. \\
\hline Earth, & Daiar. & Iron, & Haiarn。 \\
\hline Eaft, & Dwyrain. & Ifland, & Ynys. \\
\hline $\begin{array}{l}\text { Egg, } \\
\text { Eye, }\end{array}$ & IV $\mathrm{y} \cdot$ & & \\
\hline $1 y<$, & Liygad. & $\begin{array}{l}\text { King, } \\
\text { Knife, }\end{array}$ & $\begin{array}{l}\text { Brenin. } \\
\text { Cyllell. }\end{array}$ \\
\hline Father, & Tad. & & \\
\hline Feet, & Traed. & Lake, & Llyn, pl. Llyro \\
\hline Finger, & Bys,pl.byfedd. & & i2u. \\
\hline Fire, & Tàn. & Land, & Dacar. \\
\hline Fifh, & Py§g. & Leather, & Lledr. \\
\hline Fleft, & Cig. & Leg, & Coes. \\
\hline Foot, & 'Troed,pl.traed. & Loaf, & Torth. \\
\hline & & Man, & Dyn,pl.dynic \\
\hline Goat, & Gafr. & & or gwyr, \\
\hline
\end{tabular}

* This word fignifies properly a meal, and is occafionally ufed for breakfaft as well as dinner. 
OF THE WELSH LANGUAGE.

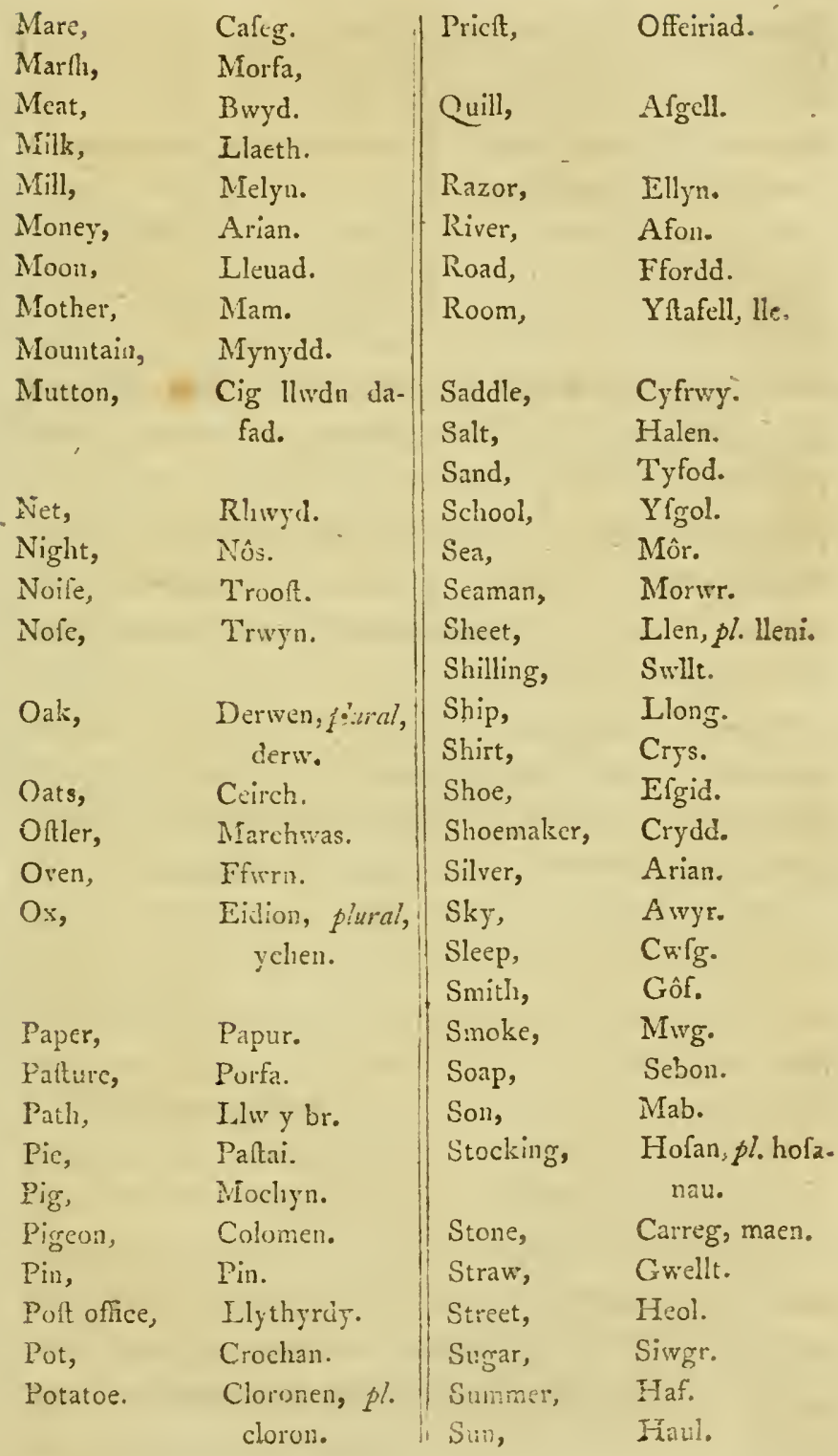

Table, 


\begin{tabular}{ll||ll} 
Tabie, & Bwrld, llech. || Vaie, & Dyffrym. \\
Tailor, & Taeliwr. & Veal, & Cigllo. \\
Teeth, & Daint. & Wall, & Mur. \\
Thluread, & Edau, edef & Wafherwoman, Golchyddes. \\
Towel, & Llaw-liain. & Water, & Dwr. \\
Town, & Tre. & Well, & Ffynnon. \\
Tree, & Pren. & Wheat, & Gwenith. \\
Trout, & Lrithyl. & Wine, & Gwin.
\end{tabular}

The prefent Welfh letters are the fame that are ufed in England, but there appears fufficient proof that the alphabet, now called the Saxon alphabet, really belonged to the Britons, and was ufed in their writings many centuries previous to the Saxon invafion. When the Britons were driven out of Mercia, a few of the moft learned were fuffered to remain, and from theie, it has been conjectured, the Saxons were firft inftructed in the ufe of letters. It is deferving of remark that Afrerus and Scotus, the inftructors of Alfred, were both Welfhmen.

When the Saxons firft came into Britain, about the middle of the fifth century, they appear, fays Dr. Johnfon, who examined every record extant on the fubject, "to have been a people without learning, and very probably witbout an alphabci."

It has been juftly remarked by the learned and indefationable Rowlands, that if they had brought the ufe of letters with them from Saxony, or whereever they came from, there would have been fome remains either of infcriptions or manufcripts in that country, minls.s they had all come over, to a man, and brought 
brought with them all their books, and their tombftones alfo. In no part of Germany is there fuch a character as the Saxon to be found.-That they invented the letters after their arrival in Britain, is altogether improbable; for, at all events, there was at that time the Roman character ready to their hands, and in common ufe.-The Irih hiftorians fay that they borrowed them from that country. It is probable that the Irifh had the letters, as well as their language, in common with the Britons; but there was little neceffity for the Saxons to go over into Ireland to borrow what they would find in their own ifland and neighbourhood.

That the Britons ufed this alphabet in the moft remote periods, feems alfo extremely probable, exen from an expreffion of Cæfar, in his defcription of the Druids, "Gracis literis utuntur," " they ufe the Greek letters :'-feveral of thofe, now called the Saxon characters, have a great refemblance to the letters of the old Greek alphabet.-Many of the ancient Britifh manufcripts are alfo written in the Saxon character, as part of the Liber Landavenfis, and feveral depofited in the libraries in North Wales:-In one of the prefaces to Lhwyd's Archæologia, there are three ftanzas of the ancient Pictin poetry, which the author difcovered in the Highlands of Scotiand. They were written on vellum, in this old character, or in one very nearly refembling it, and he believed them to be above a thoufand years old.-There is yet to be feen on a ftone over the fouth door of the VOL. II. 
church of Llangadwaladr, in Anglefea, this infcription, in the old character: "Catamanus rex fapientifinus, opinatiffimus oninium regum." Catamanus, or Cadvan, died in the beginning of the feventh century. The church was founded by his grandfon-About the reign of Charles II., the fexton of Lanbabo, in Anglefea, was digging a grave, when he by chance difcovered, at the depth of feveral feet, an ancient tombltone. It was taken out and depofited in the chancel, where it is yet to be feen. It has on it the figure of a man, in long robes, with a coronet on his head, and a fceptre in his hand. Round the edge there is a Latin infcription in thefe old chamcters, mixed with the Roman. It was defigned to commemorate Pabo poft Prydain, Pabo, the fiopport of Britain, who lived about the period when the Saxuns firt entered Britain. He has been celebrated for his valour in the contentions, with the Britons, againft the Picts and Scots:- - he was the founder of the church of Llanbabo.-There are many other monumental infcriptions in North Wales in this ancient character.

Another evidence that the Britons had an alphabet previoufly to the arrival of the Saxons, is adduced from infcriptions on Britifh coins ftruck fome centuries before. In Dr. Stukeley's impreffions from the coins of the ancient Welfh kings, there is one from a coin of Bleiddyd, or Bladud, king of Britain, about nine hundred years before Chrif. This is now lodged in the Cotton mufeum. There are others 
thers of Manogan, about a hundred and thirty years before Chrift; of Cynvelyn, or Cunobelin, king of the Caffivellauni, at the commencement of the Chriftian æra, \&c.

In the reign of Henry VIII., a table of metal, apparently of lead and tin mixed, was difcovered at Ambrefbury in Wilthire, infcribed with many letters, but in a character fo uncommon, that neither fir 'Thomas Eliot, nor Mr. Lily, the mafter of St. Paul's fchool, were able to underftand them. It was in confequence neglected; it might otherwife have led to fome important difcovery.

Previoufly to the arrival of the Romans into thefe iflands, the Welfh, then the Britifh language, was the only language in ufe. From the Romans fome new words were added to its dictionary. After the expulfion of the inhabitants by the Saxons, it fled with them to the mountains, receiving, however, a few additions from this people. In the Highlands of Scotland, Wales, Ireland, and Cornwall, it continued to be ufed for many centuries, in exclufion of every other language. In many parts of North Wales it continues yet to be fpoken in its original purity. The Englifh have, indeed, for a few cen. turies, been fo much encroaching upon this country, as to have rendered their own the fafhionable language, and in general the only language fpoken by the hirgher orders of the people. Attempts have $\times 2$ alfo 
alfo been made to introduce the Englin tongue into general ufe among the lower claffes, but hitherto with no great fuccefs. Englifh charity-fchools have for many years been inftituted in various parts of the principality, but thefe feem to threaten nothing ferious againt the language of the country. The little that the children learn from inftructors who themfelves know but little, is foon afterwards loft in the natural preference they have to their own tongue, and the little orcafion that they have to fpeak any other. To fay that the majority of the Wellh are entirely ignorant of the Englifh language would be wrong, for in thofe parts of Flinthire, Denbighfhire, and Montgomeryfhire, adjacent to the Englifh counties, they fpeak it very fluently. It is in Angle$\mathrm{fea}$, and the mountains of Caernarvonhire and Merionethfhire, where the greateft ignorance of it is to be obferved; but here, in the great roads, I had commonly Englifh anfwers to my queftions; and even in more obfcure fituations, by a little perfeverance, or by the exhibition of money, I have obtained the anfwers I fought for.

A late Wellh writer has remarked that "fome advocates for the abolition of the Wellh tongue are vain enough to prognofticate a near approaching day, when it will be numbered with the dead languages. They fee fome few families on the borders, and about a dozen imkeeners upon the poft-roads, who fpeak Eriglifh only; but there are thoufands, 
and tens of thoufands in the wilds of Wales, who have learned the language of their parents, and of their country, as naturally and as innocently as they fucked their mother's breafts, or breathed the common air: thefe have neither opportunity nor inclination to lean any other tongue. This is the impregnable fortrefs of the Wellh language, where a rivetted, cordial antipathy againft the Englifh tongue, caufed by the cruelties of Edward I., and of the Lancaftrian family, dwells as commander in chief. Storm this garrifon, and overturn Snowdon from its bafe*!"

* Of the truth of the cruclies faid to have been inflicted by Edward I. on the bards, further than profcribing the profeffion of bardifin, there feems great doubt. Allowing, however, all that have been alleged to him, in their fulleft extent, to be true, thefe crueltics cannot furely be adduced as jutt caufe for obfervations fo illiberal as the above againt the prefent Englifh, living five hundred years after the fuppofed date of thefe events. In the lower orders of the Welh, fuch prejudices 'might be overlooked, from their ignorance, and the want of knowing better: but from an intelligent writer, and a clergyman, thefe, and remarks like the following, though too illiberal to wound our feelings, are certainly inexcufable:- " This mode of burlefquing the Weln (for the wrong pronunciation of fome Englifh words) originated in the ridicule with which the Saxon victors treated their conquered vaffals; and which is till carried on, in fpite of reafon and liberality, by the folly and ignorance of the defcendants of our once infulling foes."

The "boorifhnefs" of the Englin peafantry "has no rival, and of their ignorance a clergyman of their own gives us SATISFACTION, who, a few years ago, on coming to his parifh, 
within twenty miles of the metropolis, could get no anfwer from feveral of his parihioners, to a very plain queftion, viz. "Who was Chrift?' Can we find fuch ignorance in Wales, - the wilds of Ireland,-or the Highlands of Scotland ?"'-See a ftatifical account of the parifh of Llanymynech, in Montgomeryinire, by the reverend Walter Davies of Meivod, inferted in the Cambrian Regifter, i 280. 


\section{$(311)$ \\ C. H A P. $\mathbf{X X V}$.}

SKetch of the History of the Welsh Bards AND Music*.

Acsount of the Druids, their Funizions, Manners, and Cuftoms.Their Externination by the Romans. - The fubfequent State of Poetry and Mufic. - The Reformation effeted by Griffeth of Cyman, in the Truelfith Centary. The Claffes of the Bards.The Eifeddfod, or Triennial Agembly. The Degrees in Poetry and Mufic. - The Privileges and Revesures of the Bards. - Their fuppofed MafJacre by Order of Edward I. - Their Hiffory. continued from thence to the prefent Time.-Aicourt of the Wells Mufical Infruments. -T The Harp. - The Crwutb. -The Pibcorn. - Obfervations on the Wel/h Mufic.-Objettions to the Laws of Counterpoint being known among the ansient Bards; and the generally fuppofed Antiquity of the prefent national Tunes. - Chasratier of the prefent Wells Mufis.

$F_{\text {rom }}$ all the authentic memorials extant refpecting the ancient Britih bards, it appears that in the carly periods they conftituted that order of men denominated by the Latin writers Druids. They were divided into three principal claffes of druid, bard, and ovate $f$.

They

* This fubject will be found more extenfively illuftrated in Mr. Jones's two works, "The Mufical and Poetical Relics of she Welh Bards," and "The Bardic Mufeum."

- † Denominated in Wclih derwydd, bardd, and orydd.Derwydd Ggnifies the body of the oak, and, figuratively, the 
They had one chief, or arch-druid, to whom the whole order paid implicit obedience; and under whofe directions their moft important affairs were conducted *. He held an annual tribunal, to which the people were regularly affembled, and in all caufes fubmitted to his judgment, his determination was conclufive, and from it the parties could have no appeal. After the death of the arch-druid, the next in dignity and reputation, decided by a majority of rotes of the inferior orders, fucceeded to his high office $\uparrow$.

The employment in which the druids were chiefly occupied, was the exercife of religious functions, for it was their fole prerogative to prefide over the various rites and myfteries of their worhip.-It was confidered the office of the bards to fing their religious precepts to the people: to fing to the harp at nuptials, obfequies, games, and other folemnities; and at the head of the armies to chant the praifes of thofe perfons who had fignalized themfelves by virtuous or heroic actions. To the ovate the conduct of the moft trivial duties appertaining to their

man of the oak, from derw an oak, and $y d d$, a Welfh termination of nouns. - Bardd fignifies the branching, or what fprings from, derived from bâr, a branch, or top. - Orydd implies a difciple, from $\hat{o} v$, raw, and $y d d$, the termination above explained. Jones's Bards, p. 2.

* His omnibus Druidibus preeft unus, qui fummam inter eos labet auctoritatem. Cæefar, lib. vi. f. гз.

+ Ibid. 
religion devolved. The perfons who filled this clafs were in a kind of noviciate to the higher and more important offices of bard and druid. They had the care of the facrifices, and principally occupied their time in the ftudy of natural philofophy.-In the tragedy of Caractacus all thefe orders are recog: nized: Vellinus, having fpoken of the arch-druid, fays,

His brotherhood

Poffers the neighbouring cliffs.

On the left

Refide the fages fkilled in nature's lore :

The changeful univerfe, its numbers, powers,

Studious they meafure, fave when meditation

Gives place to holy rites: then in the grove

Each has his rank and function.-Yonder grots

Are tenanted by bards, who nightly thence,

Robed in their flowing velts of innocent white,

Defcend, with harps that glitter to the moon,

Hymning immortal Atrains.

The druids and the bards were the divines, the legiflators, and the phyficians of the ancient inhabitants of this country. They compofed hymns for their facred temples, and thefe they accompanied with their harps. In later periods, when the druidical orders had fuffered from the encroach. ments of the Roman power, they were employed in recording the defcent of families, in emblazoning their arms, and compofing fongs on the valiant actions of illuftrious warriors, which they chanted to the mufic of their harps. Thus, con. fequently, 
fequently, they became the national hiftorians. On important occafions, the bards were made ambaffadors between contending chiefs; but at all times their perfons were held facred. "Cairbar (fays Ofian) feared to ftretch his fword to the bards, though his foul was dark. Loofe (faid the noble Cathmor) the bards. They are the fons of other times. Their voice thall be heard in other years, when the kings of Temora have failed." They were exempted from all military fervices, even in times of the greatef danger; and whenever they attended their patrons into the field of battle, to fing their heroic actions, a guard was affgned for their protection.

The druids certainly worfhipped either a multiplicity of deities, or one God under feveral different appellations*. To them they officed human victims: thieves, robbers, and other malefactors, were preferred; but if thefe were not to be had, they facrificed innocent perfons. Diodorus Siculus afferts that condemned criminals were referved, and at the end of every five years were all facrificed at once. Captives of war were alfo immolated in the fame manner $t$.

I have been informed that one relic of druidical facrifice is yet obferved in fome parts of North

- Among thefe were Teutates, or Mercury, and Apollo, Mars, Jupiter, and Minerva, under different Britifh names. Cæfar, lib. vi. f. 17 .

+ Strabo, vi. 198. จ. 32. Cxiar, vi. 16.

Wales. 
Wales. When any contagious difeafe breaks out amongft the horned cattle, the neighbouring farmers each contribute towards the purchafe of a bullock, which is led to the verge of fome precipice, and caft headlong down. This act they call brurw caeth $i$ gythraul, "cafting a captive to the devil."

It has been faid that the druids taught the Pythagorean doctrine of the tranfmigration of fouls; Lucan and Marcellinus, however, each reprefent them as teaching, that after death the foul retired into fome higher orb, where it enjoyed a fate of perfect happinefs *.-They performed all their acts of worthip in the open air; and in places appropriated to the purpofe, furrounded with groves of oak $t$. In thefe they had their mounts and hillocks, which were denominated gorfeddau, from their fitting aloft upon them when they pronounced their decrees and fentences, and made their folemn orations to the people; and in thefe they erected thofe fingle upright ftones to which fome writers think they yielded divine honours, as the memorials of their deified warriors.

The druids placed a very high myitery in the milletoe that grew on the oak. At the clofe of their year they marched in folemn proceffion to gather this plant, in order to prefent it to their Gods. They invited all to affift in this ceremony, by proclaiming to the world-"The NEW $\Upsilon_{\text {LAR }}$ is at band,

* Lucan, i. 455. Mareell. xv. 9 .

+ HiR. Nat. lib. xvi, c. 44. 
gather the mifletoe." As foon as all the facrifices were ready, the prieft afcended the tree, and with a golden hook cut off the mifletoe, which was received on white linen fpread on the ground for that purpofe. Two white bulls, that had never been yoked, were now brought out and offered in facrifice, and prayers were made for the profperity of thofe on whom fo precious a boon had been beftowed. The miftletoe thus gathered was deemed a certain antidote to all kinds of poifon; and it was ufed as a fpecific in various difeafes.

The fixth day of the moon commenced the druid's month, and on this day it was that their moft facred folemnities were performed. It appears probable that, with the generality of mankind, they fet apart alfo one day in feven for religious worthip. They had other feftivals and folemnities, but at prefent we know not what they were.

In all the orders of druidifm the hair was worn very fhort, and the beards extremely long. All wore long habits; and the druids, when performing their religious rites, were clad in robes of white, emblems (they taught) of their truth and piety. The bards on thefe occafions wore azure garments, with cowls to them, as fymbols of heaven, peace, and fidelity. The garments of the ovates were green, emblems of learning and truth.

The candidates for the rank of druid underwent a noviciate of twenty years. During this time they had to learn thofe almoft innumerable verfes in which 
which the principles of their religious and civil polity had been preferved by uninterrupted tradition through many centuries. They were, indeed, acquainted with the ufe of letters, but they did not deem it lawful to commit thefe verfes to writing, in order that their intellectual faculties might be ftrengthened, and alfo that their myfteries fhould be withheld from the contemplation of the vulgar.The metre in which thefe oracular inftructions were communicated to the people, was a kind of triplet ftanza. The Englifh reader will have a tolerable idea of their conftruction from the following tranflation of five of them, inferted (with feveral others) in Jones's Relics of the Welfh Bards. Thefe have the fame number of lines and feet as the originals; and the fenfe is preferved as nearly as the limits of the metre would allow. The two firft lines do not feem to have much connexion with the laft; there, appears, however, to have been no fmall degree of art employed in their compofition. In the firft lines the druid defcribes either actions that are familiar to every one, or the appearance of vifible objects. He then concludes with a moral precept, or a proverbial fentence ; and by annexing to it undoubted fact, art: fully implies that the truth of the maxim is as clear and well eftablifhed as the identity of material objects :

In the oak's high towering grove,

Dwells the liberty I love.-

Babblers from your truft remove. 
Liberty I feek and have,

Where the green birchen branches wave.-

Keep a fecret from a knave.

Snow a robe o'er hamlete flings;

In the wood the raven fings. -

Too mucb Jleep no profit brings.

When the mountain fnow is fpread,

Stags love funny vales to tread.-

$\checkmark$ ain is forrow for the dead.

Fair the moon's refplendent bow,

Shining on the mountain fnow. -

Pedce bo wicked never know.

The immenfe power that the druids had acquired, drew on their heads the vengeance of the Romans, who in other inftances were not often intolerant. The pretext for firt attacking them was the cruelties committed in confequence of the horrid rites of their religion : the true reafon appears, however, to have been the great influence that they had obtained over the minds of the people. In Gaul they are faid to have been entirely deftroyed under the reign of the emperor Claudius, before the year 45: and, in Britain, Suetonius Paulinus, the governor of the country under Nero, having taken the inland of Anglefea, not only cut down the facred groves of the druids, and overturned their altars, but alfo confumed many of the druids in their own fires*. All who efcaped this maffacre fled immediately from the country, and fought for refuge in Ireland, the iflands of Man and Bardfey, where the Roman fword had not then reached.

* Tacit. Ana, xiv, §o. 
From the deftruction of the druids by the Romans to the commencement of the fixth century, we have but few accounts (and thefe very obfcure and imperfect) of the actions of the bards; but at this period they began to refume the harp with an energy that for many centuries had been unexampled, to animate their country to refift the Saxon yoke. From the ninth to the eleventh century, if we are to judge from the few pieces faid to have been compofed during that time, their mufe feems again to have received a check.

The hiatus continues till the time of Griffith ap Cynan, who reigned in Wales in the beginning of the twelfth century. This prince effected a very effential reformation in the diforders which had prevailed among the bards. He had been educated in Ireland: and either from having imbibed a parthality for the mufic of that country, or from the fuperior excellence of the Irifh to the Welfh muficians, he invited feveral of the moft eminent of them into Wales, under promifes of great reward; and with their concurrence and advice formed a complete body of infitutes for the amendment of their manners, and the correction of their art and practice *.

To effect this reformation it was firft neceffary to divide them into claffes, and to affign to each clafs 2 diftinst profeffion and employment. The qualifications neceffary for a bard were declared to be

* Powel.

learning 
learning and genius, a fkill in pedigrees, an acquaintance with the laws and metres of poetry, a knoweledge of barmony, a fine voice, and ability to play on an inftrument. It was made their office to applaud the living, and to record the memorable actions of the dead. They were divided into three grand orders of poets, beralds, and muficians; and each of there again branched into fubordinate diftinctions.

Of the poets, the firft and principal clafs confifted of hiftorical or antiquarian bards, who occafionally pretended to infpiration, and the confequent powers of prophefy. They were critics and teachers, and to them belonged the praile of virtue and the cenfure of vice. From their great practice and fuperior qualifications, their poetry, and the powers of their genius, were confidered fupereminent.-The fecond clafs was formed of the domeftic bards. Thefe refided in the manfions of the great, to celebrate their warlike actions, and their amiable qualities. They fang the praifes of generofity, contentment, domeftic happinefs, and all the focial virtues; and thus contributed to enliven the leifure of their patrons.

The herald bards were confidered as the national chroniclers. They were well verfed in pedigrees, and the blazonry of arms; and in the works of the primary bards. They could trace back the pedigrees of their princes and nobles not only as far as the Trojan refugees, but even to the creation of the world. Their poetry was of a more humble kind than that of the firft order of bards: it was ufually 
- confined to fubjects of jocularity, mimickry, invective or reproach.

Of the mufical bards, the firt clafs was appropriated to performers on the harp. The fecond contained performers on the fix-ftringed crwth. The third confifted of fingers, whofe employment it was to fing to the harps of others the compofitions of the poetical bards: but in all thefe a variety of óther qualifications was expected.

A triennial meeting of the bards, called the eifteddfod, was alfo appointed by Griffith ap Cynan for the regulation of poetry and mufic. By this affembly the honnorary degrees were conferred. Its prefident was the bard, who, after a mufical and poctical contel, was declared fuperior to all the reft. It was ufually held at Aberfiraw, in Anglefea, the royal feat of the ancient princes of North Wales; but fometimes at Dine Vawr, in Caermarthenfhire, the refidence- of the princes of South Wales; and fomctimes at Mathraval, in Montgomeryfhire, the palace of the princes of Porrys.

It was neceffary for cvery perfon who wifhed to be enrolled in the eifteddfod, in order to procecd to degrees in potry, firt'to obtain permifion of the prince, or lord, within whofe juriftition he refided *. On his prefentation at the enfining afiembly he was required to explain the five THelih metres of fong; and to fing them in fuch a manner, that one of the

* The reafon for this was, that a vaffat, o: his admiffion into the practice of poetry and milic, acquired the privileges of a frecmain, and an honourable rank in focicty.

VOL. II. 
principal bards would declare upon his confcience, that the perfon was competent to be admitted. He then became a pupil to fome one of the principal bards, whom he annually attended in Lent, and without whofe approbation he could make no compofition public. During thrce years, till the next eifteddfod, he remained an under-graduate, or "probationary ftudent of poetry *."-At this eiftedalfod he was examined for the degree of "bachelor of the art of poetry." - After another like interval, he took the degree of "mafter of the art of poetry." For the latier it was required that he fhould underftand the rules of grammar and rhetoric; that he fhould analyfe and explain the alliterative concatenations of the language, and fing melodiounly, in parts, twenty-one of the metres.'To the pcncerdl, or " profeffor of poetry," who attained his degree at the next enfuing eifteddfod, belonged the whole myftery of the art. It was neceffary that his qualifications fhould be much fuperior to thofe of all the perfons who were ad. mitted to the other degrees; and it was declared particularly requifite that he fhould have a facility in compofing, in praife of the great, what would be heard with moft delight, and longeft retained in memory.

The degrees in mufic appear to have been very fimilar in their nature to thofe in poetry. The higheft was pencerdd atbraw, or "doctor of mufic."

* The Welh appellation was difgybly/pas cerdd davod: for the firtt degree, or that of bachelor, it was dit. $y y b l$ diff $y$ blaidld; and for the next difgybl penceirddiaidd. 
The eifteddfod was a rigid fchool. The poetical, or mufical difciple, who, at the expiration of his triennial term, was not able to attain a higher degree, was always condemned to lofe that which had been previouny conferred upon him.-The laws of the eifteddfod alfo ordained, that if a difciple was feen in taverns, or other places, playing at any game for money, any perfon prefent fhould be authorized to take from him all the money he had in his purfe. For mockery and derifion, or the invention or propagation of falfehood, the difciples were punifhed by fine and imprilonment: the laws fay that the bards thall be peaceful in their manners, friendly in their difpofitions, and humble in their fervices to the prince and all his adherents.

The bards were at all times held in the higheft repute, not only by the nobles, but even by the princes of Wales. The court bard was, in rank, the eighth officer of the king's houfehold, and was very often of his council. Whoever committed only a flight injury to his perfon was fined fix cows, and a hundred and twenty pence. The murderer of a bard was fubject to the penalty of a hundred and twenty-fix cows. He attended the prince's army to battle, and, in cafe of conque?t, was rewarded with the moft valuable beaft that remained after the prince's fhare in the fpoils had been taken away. Nothing can difplay more forcibly the eftination and influence which the bards enjoyed in the early periods, than their remarkable prerogative of peti- 
tioning for prefents by occafional poems. 'This cuftom they carried to fuch lengths, and fuch refpect was conftantly paid to their requens, that at the remodeling of their laws by prince Griffith ap Cynan, it became neceflary to lay this privilege under fome reftaint. From this perion they could not afk for the prince's horfes, hawks, or greyhounds, nor any other polfefion beyond a certain value; nor for any hing that the orner particularly efteemed, or which could not be replaced.

Their revenues arofe from prefents that they received at nuptial folemnities, and from the fees that were paid to them during their circuits at Chrifmas, Eafter, Whitfuntide, and in their triennial clera, or grand circuit. On thefe occafions they were received into the houfes of the great, and remained there as long as any feafing lifted. They were alfo allowed a certain fum out of every plough-land within their diftrict. Their payments were proportioned to their degrees.

Befides the regular, or graduated bards, there were four clafles of inferior and unlicenfed bards. Thefe were a meaner and-more unfkilful fort of muficians and poets. They were pipers, players on the threeftringed crwth, taborers, and buffoons. They had no connexion whatever with the eifteddfod; and their eftimation. and emoluments were equally inconfiderable.

The period that intervened betwixt the beginning of the twelfth, and the end of the thirteenth centuries, 
turies, or betwixt the reign of Grifith ap Cynim, and that of the laft prince Llewelyn, is the brighteft for talent in the bards that the Wein annals can boaft. During this interval fome of the noblet monuments of their genius were produced. Unfortunatel $j$, horwever, at the prefent day little elle is extant than the names of the bards.

- By the cruel policy of E.dward I., who, although he had conquered the country, did not think himfelf fecure in his triumph, whilft the warm and energetic fongs of a race of men, deemed alnioft infpired, were permitted to orerawe the vulgar, was effected, if we are to believe the affertion of fir John Wymne, a total mafucre of the Welfh bards. Whether Edward proceeded to this inhuman extremity or not, is at prefent a matter of little in:portance, it appears certain that he adopted modes of preventing the bards from exercifing their function. By this means they were reduced thenceforth to employ their facred art in obfcurity and forrow.

In the infurrection under Owen Glyndwr, at the beginning of the reign of Henry IV., the martial fpirit of the Britin mufe was once more revived to celebrate the enterprizes of the Wellh hero. Like himfelf, the bards of his time were "irregular and wild;" and as the taper, glimmering in its focket, gives a fudden blaze before it is extinguifhed, fo did they make one great effort of their original and daring genius, which foon afterwards was buried, with their hero, in the grave. 
Under the patronage of king Henry VII., the Cambro-britifh mufe was once again reftored. This monarch re-eftablifhed the eifteddfods, which for many years had been difcontinued; and the firft employment. given to the bards was that of making out from their authentic records the pedigree of the king.

A long interval of anarchy enfued, which was in fome meafure clofed by queen Elizabeth, who appointed cominiffioners to affemble an eiftcddfod at Caerwys in the year ${ }_{15} 68$. The perfons thus einpowered by her had inftructions to advance, at this meeting, the ingenious and fkilful to the accuftomed degrees, and to reftore to the graduates their ancient exclufive privilege of exercifing their profeffion. The reft were by this commifion commanded to employ themfelves in fome other labour, to which they were equal, on pain of being apprehended and punithed as ragabonds.

Soon after this time the bardic mectings again dwindled, till at length they almoft ceafed to exift. A fociety inflituted in London, called the groyneddigion, or North Wales men, have within thefe few years attempted to raife the art once more from oblivion. To this end they convened annual meetings in fome village or town in North Wales, and afligned fubjects for candidates to write upon, with honorary medals to fuch as were fuccefsful. One of the firft of thefe meetings was held about eight years ago at Corwen, in Merionethfhire. In an eiftedd. 
eifteddfod affembled at Caerwys, in May $179^{8}$, there were prefent twenty bards, eighteen vocal performers, and twelve harpers.

In the early periods of the Britin hiftory, the bards were confidered as the national hiftorians. During their triennial perambulation they collected and recorded all the memorable tranfactions refpecting the country that came to their knowledge. They were allowed for this labour a regular ftipend, and the bardic laws rendered them liable to imprifonment, lofs of place, and great difgrace, if they either fet down falfities, or wiffully mifreprefented facts. No man was allowed to defcribe a battle, unlefs he had himfelf been on the fcene of action. Some of the chief bards were the marnhals: they fat in council in the field, and were the informers of the prince or generals of the ftate of the combat. Thofe men could not be ignorant of any circumfances of im. portance that were there tranfacted.

\section{The Welsh Musical Instruments.}

The mufical inftruments known to the ancient Welh were only three in number, namely, the barp, the cruth, and the pibcorn, or, as it is fometimes called, hornpipe.

The barp was in fuch eftimation in Wales, that to play upon it with fome degree of fkill, was, in the early centuries, confidered an accomplifhment indifpenfibly requifite for every gentleman. It was

$$
\text { r } 4
$$
alfo 
alfo on this inftrument that the harpers were accuftomed to play in the manfions of the Welfh princes and nobility.-For many centuries it had only a fingle row of ftrings, and it was fo fmall as to be much confined in the compafs of its notes. In this ftate it was necefiary to tune it entirely afrefh whenever the performer withed to change the key he was playing in. When, however, an accidental flarp or flat was requifite in the midule of a tune, the performer was able to produce this by running up his haind clole to the uppermoft bar, and fopping the fring with his thumb, whilf at the fame time he dexterouny played the note with his finger. This piece of dexterity is now entirely loft-By the bardic law's, the under-graduates were only allowed to ufe harps itrung with horfes hair, curioufly plaited, and not with cat-gut, like the harps of the prefent day. The bodies of fome of thefe were covered with leather, over the wood, which was fewred at the back extremely tight. The pegs with which the Atrings were fcrewed were made of bone or ivory. It appears that fome of thefe-inftruments were remaining even fo lately as in the beginning of the fifteenth century; for a minftrel of this period thus defcribes himfelf and his harp:

If I have my harp, I care for no more, It is my treafure, I keep it in ftore;

For my harp is made of a good mare's fiin, 'The llrings be of horfehair, it maketh good clin. My f.ng, and my voice, and ny harp do agree, Much like the buzzing of an humble bee; 
Yet in my country I do make paltime,

In telling of prophefy which be not in rhyme.

With refpect to ftrings of cat-gut to the harps, as at prefent univerfally adopted, they were anciently much dinliked by the bards. Dafydd ap Gwilym, who died about the year I 398, thus fpeaks of them : "David had, not one ftring from dead fheep. 'The minfrels of the ferious prophet David, with all the cumning of their divination, never formed one harp exquifitely pleafing, but of thining hair. Wife is the eafy and fprightly defcription of the harp ftrung with black glofly hair.-There is none who would with for life amongft us, fhould he be fkilfed in mufic; for there is nothing but the din of this leathern harp; (fie on the office!) profperous it fhall not be, played on with a horny nail of unpleafant form*; only the gracelefs bears it.-I love not its guts founding eventful difgult,-its trunk, and its hoarfe found, were but formed for an age-ivorn Saxon.-Let every mufical profefior, from the Englif? marches as far as Mona's ifle, learn to play on a fair harp, with jetty hair; and to impart infructions as was ufual in the time of our old forefathers; as for the other giftlefs twanging one, let no difciple bear: it in the face of day!"-Some time elapfed before the double harp, or harp with two rows of

* Galilco, in his dialogue on ancient and modern mufic, fays that the performer on the harp fuffered his nails to grow to a confiderable length, trimming them with great care, and forming them fomewhat like the quills on the jacks of a harpficord.

frings 
ftrings was invented. This fupplied the deficiency, and in fome degree obviated that difficulty of playing the flats and fharps, which in all the preceding inftruments had for fome centuries been found almolt infurmountable.-The next improvement was in the invention of the triple harp. This, which is the harp now in common ufe in Wales, had its origin about the fourteenth century. Its compafs extends to five octaves and one note, namely, from $A$ in alt, to double $\mathrm{B}$ in the bafs. The three rows contain in the whole ninety-eight ftrings. The two outer rows are diatonics, and both tuned in unifon; and the middle row conftitutes the fharps and flats. The latef improvement that the harp has undergone, is in the invention of pedals for producing the femitones. For this we are indebted to a perfon of the name of Simon, who refided in Bruffels fomewhat more than forty years ago. To this inftrument there are but thirty-three ftrings, which are merely the natural notes of the diatonic fcale, the reft being made by the feet. It is an ingenious and ufeful contrivance, and has thus not only rendered the inftrument capable of infinitely greater expreffion than it ever had before, but any pallage can be executed on it that can be played on the harpfichord.

The croth, which is another of the Welf inftruments, is now fo nearly out of ufe, that even its name is farcely known to fome of the prefent harp- 
ers.-In its conftruction it is nearly allied to the violin, having fix ftrings, and being played by means of a bow. Its length is near two feet, its breadth at the bottom ten inches, and thicknefs an inch and a half. Its fides are continued in a fraight line through the whole length, and, as well as the finger-board, are joined at the top to a crofs-bar on which the tuning pegs are fixed; the upper part by this means forms a kind of frame round the hand.

Four of the ftrings are conducted down the fingerboard, and the remaining two leave it about an inch to the right. The former only are played with the bow; the latter are ftruck with the thumb, and form a kind of accompaniment to the others. Thefe are all fupported by a bridge flat at the top, (and not, as in the violin, convex, ) by which it follows that in drawing the bow acrofs them the ftrings muft all be ftruck at once, and thus produce, with proper fingering, not a fucceffion of notes merely, but of concords. The bridge alfo is not placed at right angles to the fides of the inftrument, but in an oblique direction, one end entering the found hole and refting on the back (ferving by that means the purpofe of a found-poft), and the other end placed on the belly juft above the other hole. It is tuned by pegs with a key or wreft, in a manner fimilar to the guittar. The following are the notes of each of the itrings. 


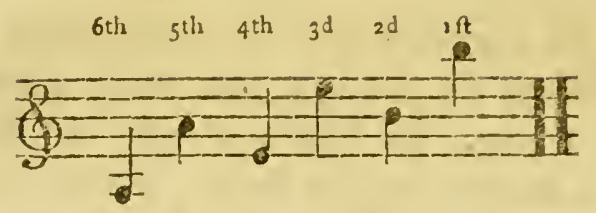

I difcovered by chance an old man at Caernarvon, who had a crwth, and was able to play a few of the old tunes upon it. The tone was far from agreeable, being altogether cxceedingly harfh. In the prefent cafe this might however be in a great meafure owing to the want of talent in the performer, and to an inftrument in itfelf ill conftructed. This old man was perhaps the only perfon in the principality, then living, who retained any practical knowledge of the inftrument.-We have no authentic information refpecting the crwth of more ancient date than the fifteenth century. There was however the figure of an inftrument very much refembling it, among the outfide ornaments of the abbey of Melrofs, in ScotIand, built about the time of Edward II. The crwth is fuppofed by fome writers to have been the original or prototype of the whole fidicinal fpecies of mufical inftruments. It feems to be mentioned as fuch in Hudibras:

His fiddle is your proper purchafe

Won in the fervice of the churches;

And by your doom muft be allow'd

To be, or be no more a crowd.

It feems, from a paffage in Spencer, to have been, at leaft fometimes, played in concert with other mufical inftruments : 
Hark how the mintreis 'gin to fhrill alond,

Their merry mufic that refounds from far;

The pipe, the tabor, and the trembling croud,

That well agree, withouten breach or jar.

A player on the crwth was denominated a cruther or crowther, and hence originated not only Butler's name of Crowdero, in Iudibras, but the furname, common in many parts of England, of Crowther*.

The Pibiorn or Hornpipe was another infrument anciently ufed in Wales, and in fome parts of Cornwall. It received its name from both the extremities being made of horn, the one to collect the wind blown into it, and the other to carry of the founds. Its length was about nineteen inches and in blowing, the air founded the tongue of a reed concealed within. In front there wrere fix holes for ix of the fingers, and there was one behind for the thumb. The tone is faid in fome meafure to have refembled that of an oboe. It was a rural pipe, and ufed by the ancient fhepherds for amufement while tending their flocks. It is now very feldom to be met with, nor was I, in either of my joumeys, able to hear of any perfon who poffefled one of them. This infrument very probably gave name to that kind of dance now called born-pipe.

* The Welfh had another intlrument of this kind wich only three ftrings, it was in confequence denominated cratb tritbant. The performers on this were held in very low ellimation by the bards on account of its want of harmony, and the fmall degree of Aill tequifite to the playing of it. 
In the conclufion of this chapter, it may be proper to fay fomething refpecting the generally fuppofed antiquity of the prefent national tuncs of the Wellh. Thofe writers who wifh it to be underftood that the lares of counterpoint were known amongt the bards, reft a confiderable portion of their argument on the account given by Giraldus Cambrenfis, of the finging of the Britons, about the year I188. "The Britons do not fing in unifon like the ininabitants of other countries; but in many difterent paris: fo that when a company of fingers amono the common people meet to fing, as is ufual in this country, as many different parts are heard as thcre are performers, who all at length unite in confonance with organic fruetnefs. In the northen parts of Britain, beyond the Humber, on the borders of Yorkfhire, the inlabitants ufe the fame kind of fymphonious harmony, except that they only fing in two parts, the one murmuring in the bafs, and the other warbling in the acute or treble. Nor do thefe two nations prictice this kind of finging fo much by art as by babit, which has rendered it fo natural to them, that neither in Wales, where they fing in many parts, nor in the North of England where they fing only in two parts, is a mmple melody ever well fung. And what is ftill more wonderful, their children as foon as they attempt ufing their voices fing in the fame manner *."

* Cambrix defcriptio. 
The glaring improbabilities in this account, as applying to the prefent laws of mufic, tend to prove that Giraldus could know very little of the fubject of which he treats. Any one acquainted with the firt difficulties attending the practice of finging in parts, can have no very exalted idea of the harmony of an zuntaught crosud, or fuppofe it little better than the diffonant paans of a good humoured mob; in which the parts would be as various as the pitch of voices of which their chorus was compofed. How all thefe could however have united at laft in the confonance of organic fiwcetnefs can' never be explained without fuppofing their tafte for mufic of a more barbarous caft than ours. As to children naturally finging in harmony as foon as they were out of the cradle, the 'idea is too ridiculous to require a moment's hefitation in pronouncing it altogether abfurd. If however, incredulity can be vanquifhed with refpect to this account of the early perfection of Welfh mufic, it would be by a manufcript lodged in the library of the Welfh fchool, near London, that was formerity the property of Mr. Lewis Morris. It contains feveral pieces for the harp, that are in full harmony or counterpoint: they are written in a peculiar notation, and fuppofed to be as old as the year I 100 ; at leaft fuch is the known antiquity of many of the fongs here mentioned. But whether the tunes, and their notation are coeval with the words, cannot eafily be proved. The title is 


\section{MUSICA NEU BERORIFTH."}

"The followiur manufcript is the mufic of the Britains, as " Settled by a congrefs or meeting of the matters of mufic by" " order of Gryffydd ap Cynan, prince of Wales, about A.D. " $\$ 100$, with fome of the moft ancient pieces of the Britains, "fuppofer? to have been handed to us from the Britilh Druids.

"In two parts (that is, bafs and treble) for the harp.

"This manufcript was wrote by Robert ap Haw of Bodwigan, " in Anglefey, in Charles the Firtt's time.

"Some part of it copicd then out of Wm. Penllyn's book."

If the Welfh people expect to prove the antiquity of thofe freet melodies fo well known in the prefent day, from this book of acknowledged authority, they will be greatly aifappointed. Thefe rude leffons are fuch in their melody as might be expected in ages when not mufic only, but when all the arts, in our countries, were in a ftate of infancy. Having had the perufal of this manufcript, I found the mufic exprefled by letters of the aiplubet, with certain other marks which cannot perhaps at this day be explained. Double fl appears to be the loweft note, after which the firt feries feems to be gi, ai, bi, ci, di, ci, fi, and the next $\overline{\mathrm{f}}, \overline{\bar{j}}, \overline{\bar{a}}, \bar{b}, \overline{\bar{c}}, \overline{\mathrm{d}}$, $\bar{c}$, written in characters fimilar to the following fac-fimiles. It is impoitible to fay that theie Icters ftand for the fame founcis as the like letters in the modern mufic: this is however of little confequence in the proof that I would inftitute. If they do, we find fome of the chords that are admitted into our harmony, but others occur that are mere jargon. The melodics whether thefe reprefent our founds or not, are extremely un- 
couth and barbarous. In proof of this I thall felect a few of thofe that appear moft fimple, and eafy of comprehenfion, firft giveing a fac-fimile of the original, and afterwards what appears to me an illuftration of it, in our notes.

Caniadd y Gruyn Bibydd, from p. 36.

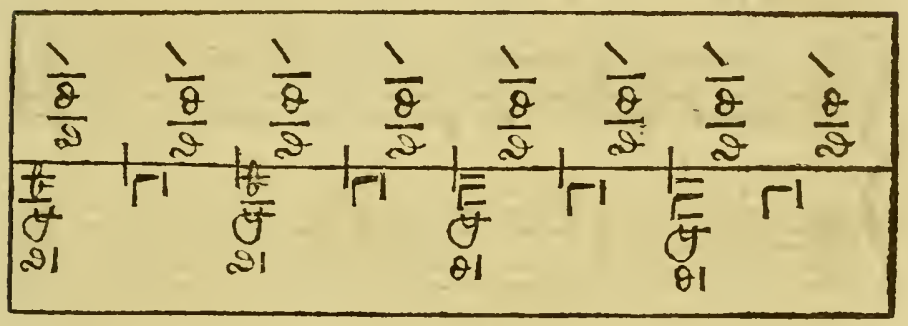

Var. I.

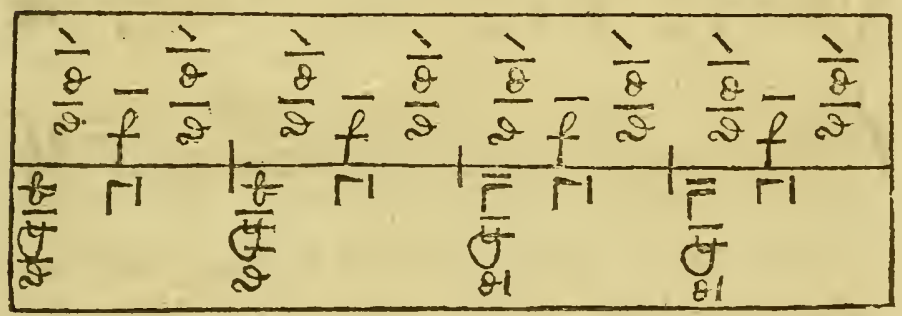

The fame in modern notes.

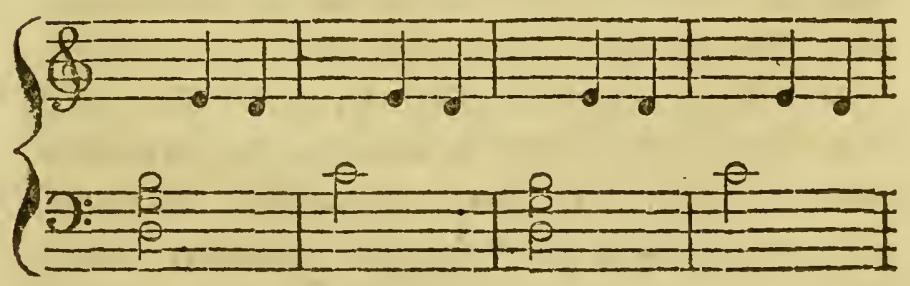

VOL. II. 
$33^{8}$ SKETCH OF THE HISTORY OF THE

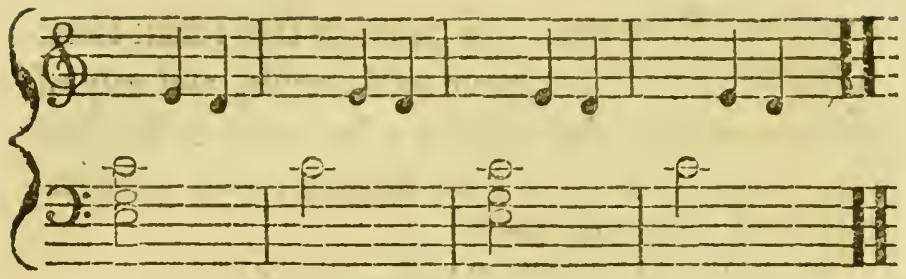

Var. I.
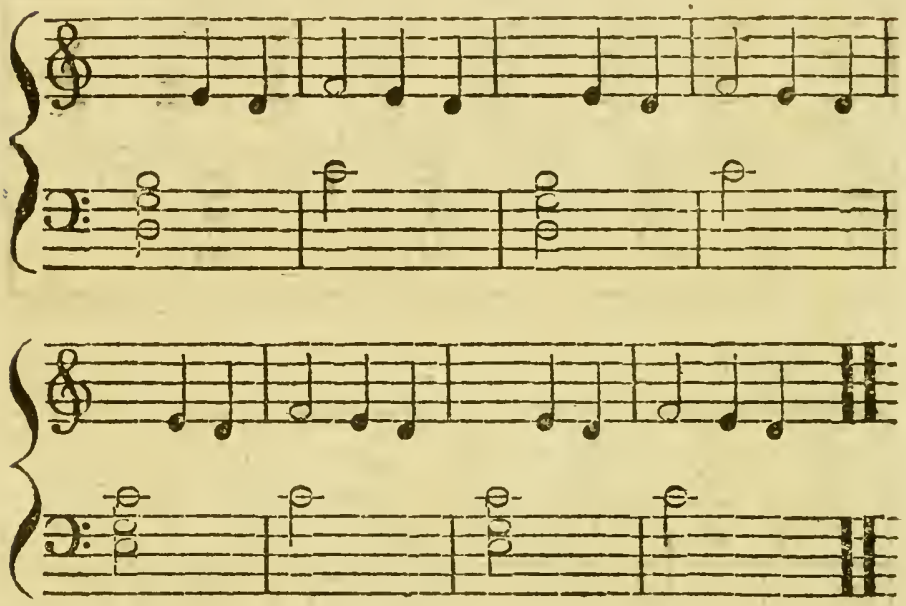

The piece I have here felected is an air, with one of its variations. In the treble of the former we obferve a conftant recurrence of two notes (be thofe what they may) precifely in the fame order throughout. The variation is produced merely by the fingle note $\vec{f}$ being inferted alternately, in the place of a reft. The oblique mark \ above the letters implies that the notes muft come in fucceflion, the upper one firt, as this mark / fignifies a contrary fucceffion. 
I hall next quote a fubject, and its firft variation, from page 28 of this manufcript:

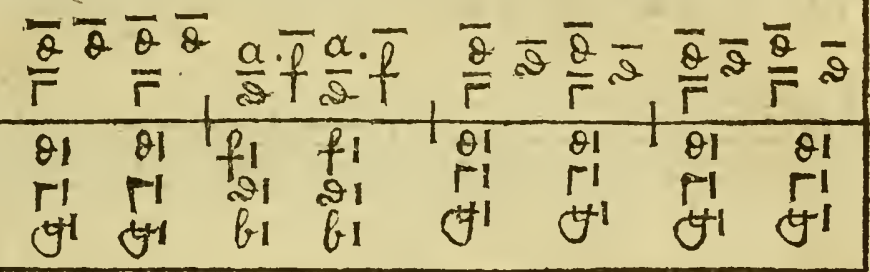

Var. I.

\begin{tabular}{|c|c|}
\hline 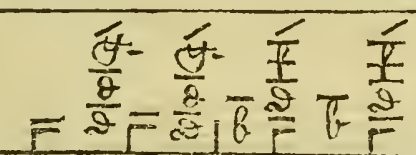 & 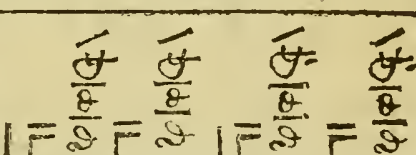 \\
\hline 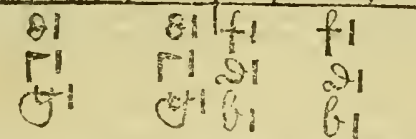 & 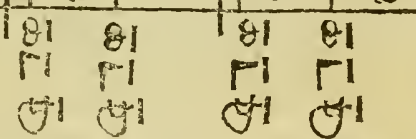 \\
\hline
\end{tabular}

The fame in modern notes.
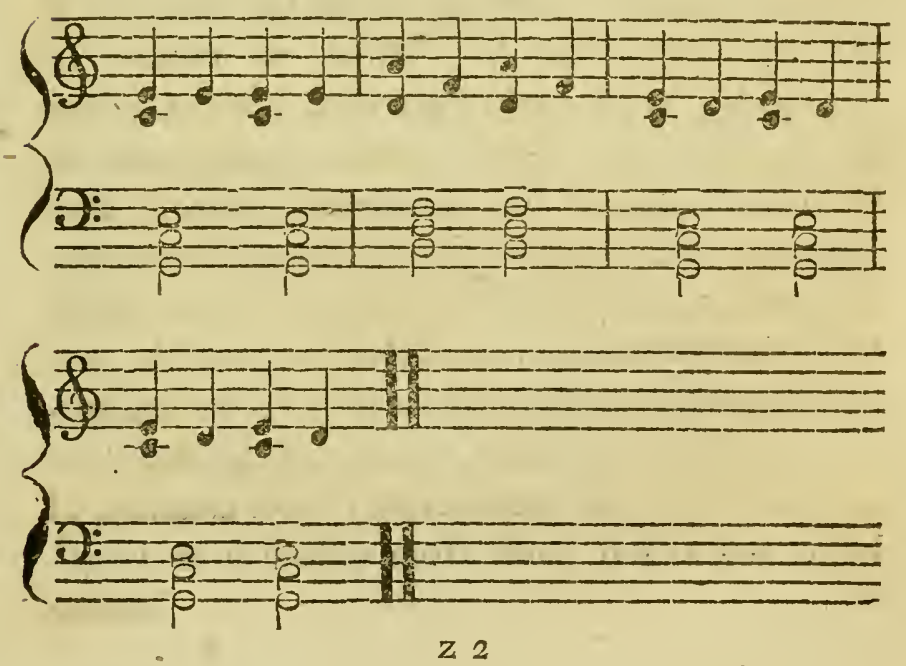
Yar. I.
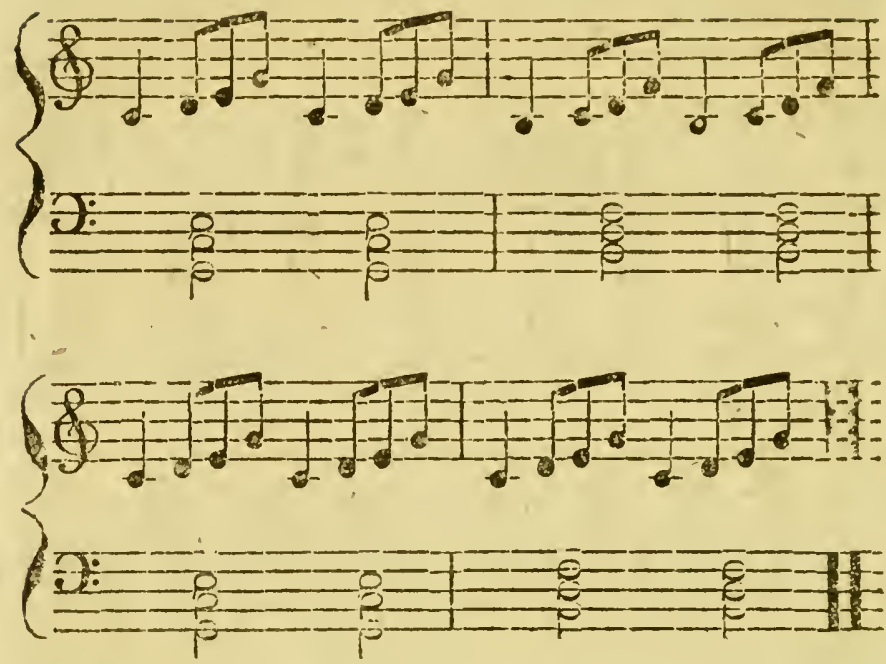

Here we have a recurrence of notes (for whatever the characters may fignify, they are evidently the fame) nearly as frequent as in the laft, and if the explanation may be allowed, we obferve an abominable jargon in the harmony. The dot after fome of the upper notes I cannot explain.-In all the other mufic of this manufcript, which I have examined with confiderable care, there feems a great famenefs, and a conftant recurrence of notes, totally unlike the varied and beautiful melodies of the prefent day.-We muft not refufe affent to the explanations, becaufe the mufic would not be fuited to modern ears. We are in every refpect creatures of habit, and as our mufic from cuftom is at length becone 
become familiar to us, fo might thefe Welfh melodies be agreaable to the ears of the Wellh people of the early periods, and fo is the uncouth mufic of favagre tribes to their own people at the prefent day. As fingular an inftance as can perhaps be adduced in proof of this, is related in Kepler's celebrated work "Harmonices Mundi." He fays, that whilft he was at the houfe of the Turkifh ambaffador at Pragie, he one day attended the prayers. One of the priefts fang fome part of the folemnity in the following notes, which, when he retired, Kepler wrote down:
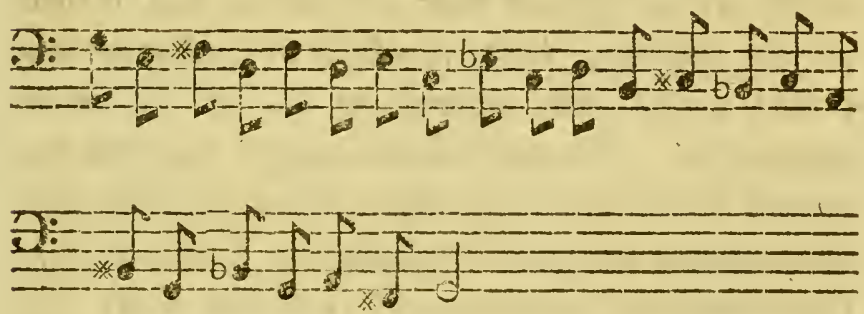

This kind of melody, Kepler fays, appeared by no means fortuitous, but was evidently derived from a depraved fyftem.

Dr. Burney doubts the antiquity of the counterpoint of this Wellh manufcript. He fays further; "That the ancient inhabitants of Wales were great encouragers of poetry and mufic, cannot be difputed, as many fpecimens of Cambro-Britifh verfification of undoubted antiquity ftill fubfift; and that thefe 
poems, as well as of thofe of ancient Greece and Rome, were originally fung and accompanied with inftruments, is very natural and reafonable to believe; but that a rude and uncivilized people, driven into a mountainous and barren country, without commerce, or communication with the reft of Europe, hould invent counterpoint, and cultivate harmony, at a period when it was unknown to the moft polined and refined inhabitants of the earth, ftill remains a problem difficult of folution."

With the foregoing fpecimens and remarks, it is no very eafy takk to reconcile the accounts which the Welh writers give of their own mufic, and of their prefent melodies, many of which are referred to a period confiderably anterior to that of the above manufcript. We muft either fuppofe that the accounts which the bards have left us of their own proceedings, are much enveloped in fiction, or that this manufcript contains mufic compofed many centuries previous to its date, and when the fcience was yet in its infancy. In this cafe we are fuprized at the counterpoint : by the former fuppofition we fhall be led to conjecture, that moft of the mufic at prefent in ufe, is that of modern times, of which, in. deed, its regularity, and the artfulnefs of its contexture, feem to afford, fufficient proof.

The prefent Wellh mufic, in its characterific wildnefs and irregularity, bears a confiderable refemblance to that of Ireland, but in the fweetnefs of 
its modulation it approaches, though it is much inferior to, the Scotch mufic. The airs that bear marks of greateft antiquity are grave and folemn : the plaintive airs are ftriking and pathetic; whilf the dances and jigs, on the contrary, are extremely lively and cheerful. 



\section{Sixteen Admired}

\section{WELSH Airs.}

'The first of August. Y Dydd Cyntav o Aust .

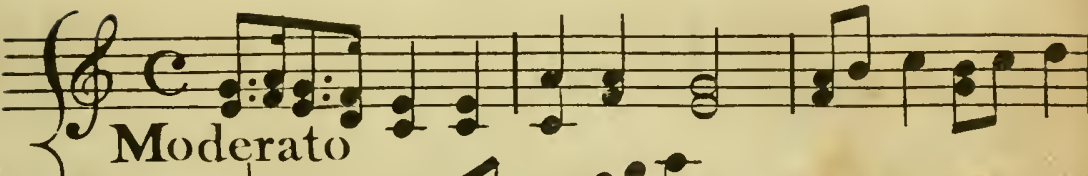

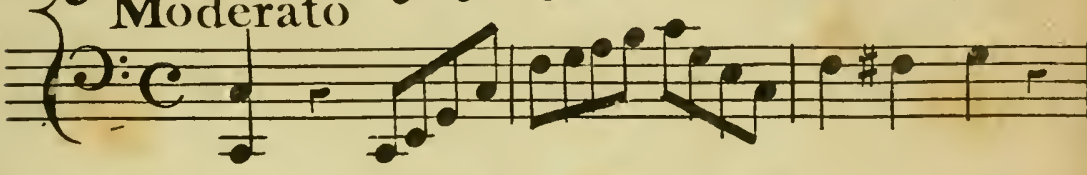

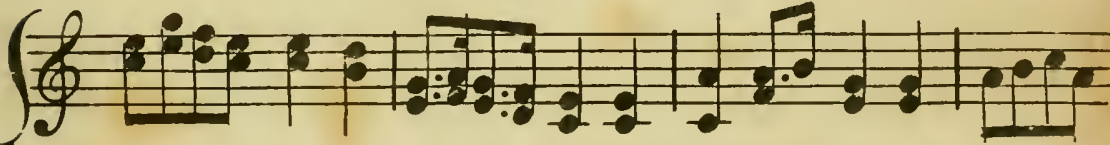

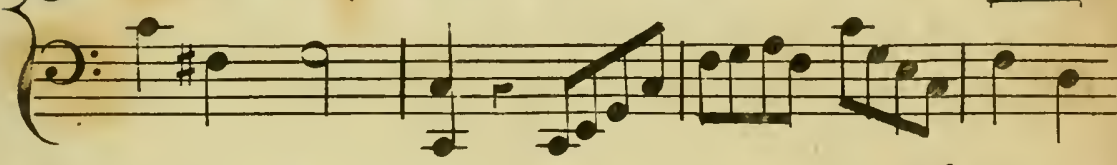

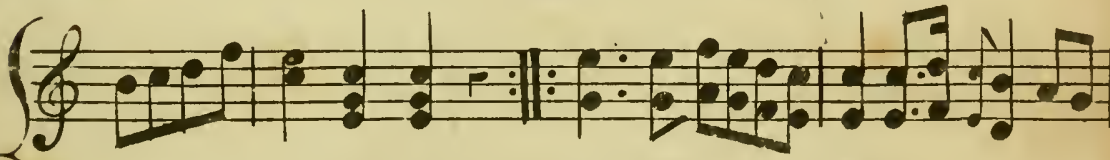
D:1 +
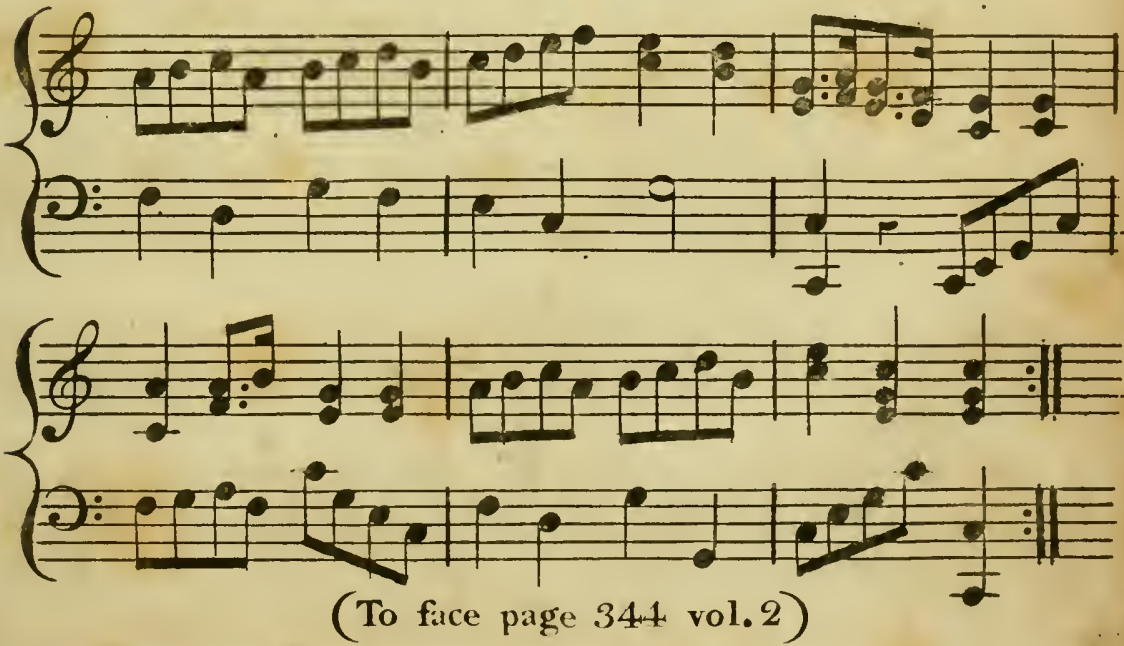

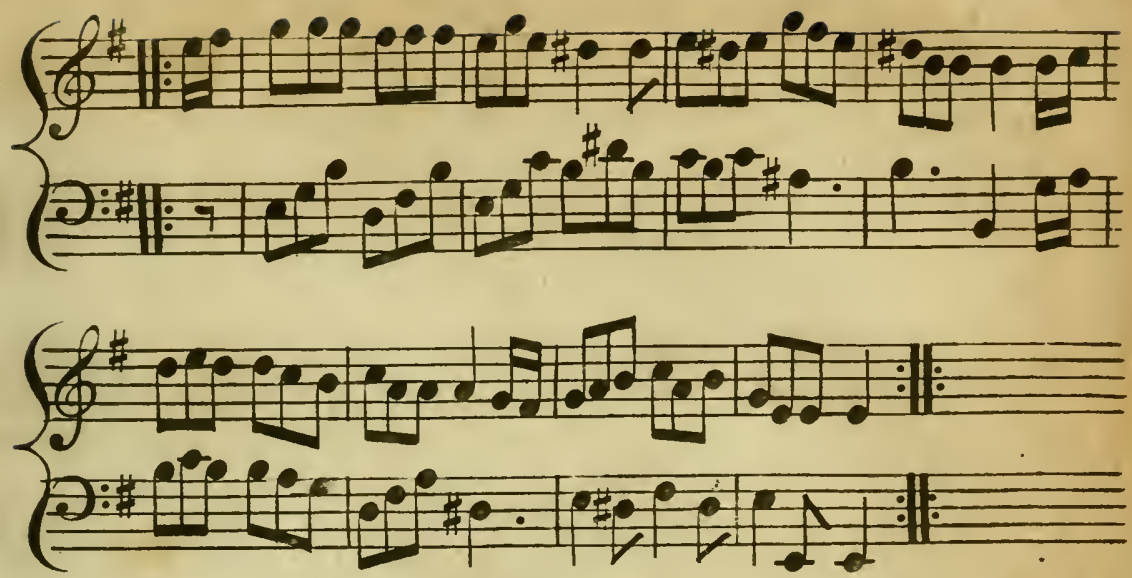

Lady Owen's delight. Dvyrwch Arlwyddes Owain. $=60$ (6) $\{$ Allegretto

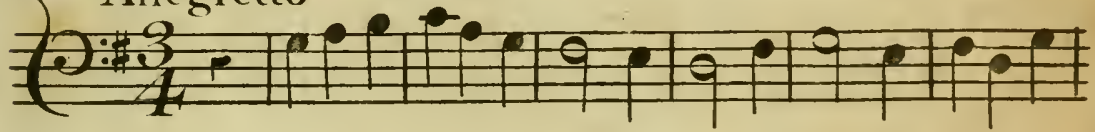
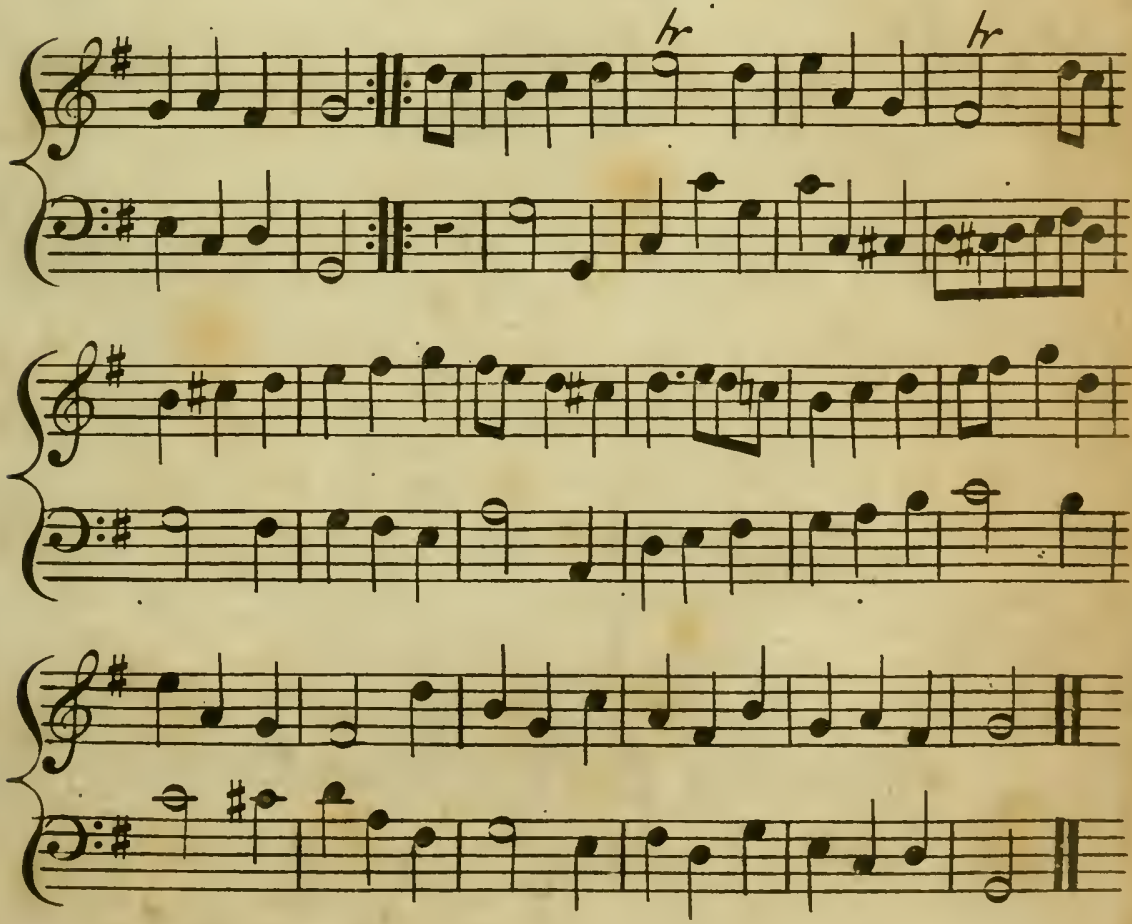

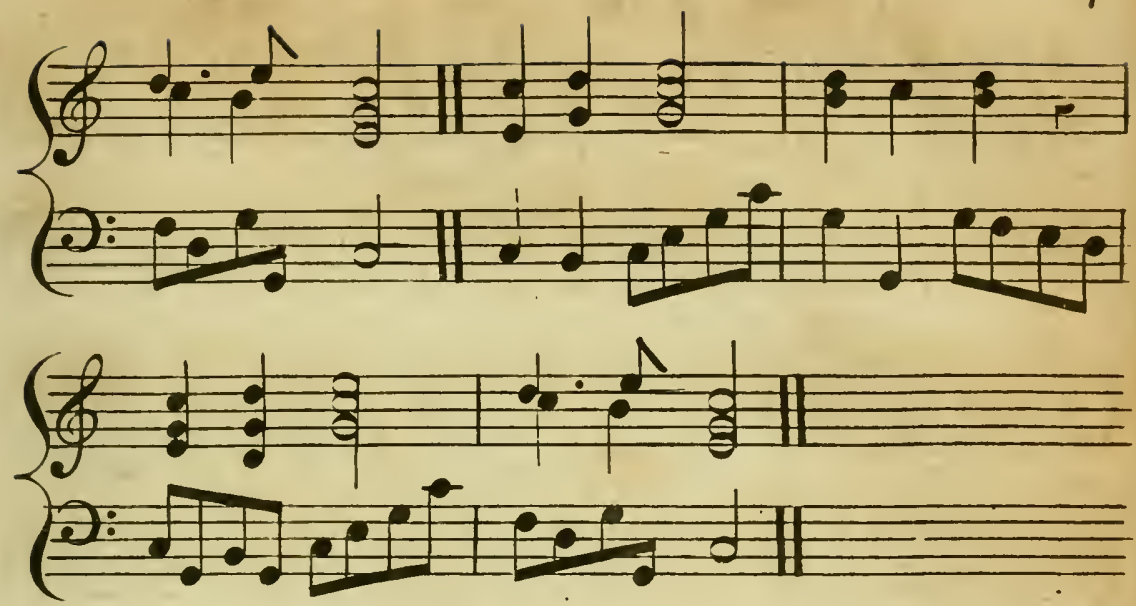

The Ash Grove.

Llwyn On

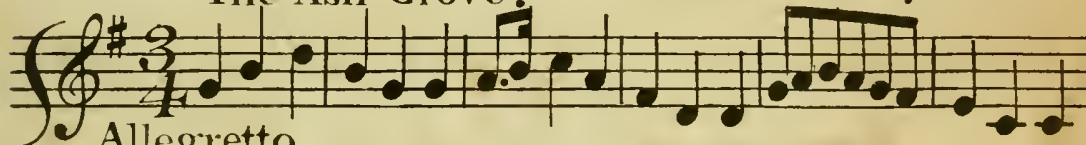

Allegretto

奉计

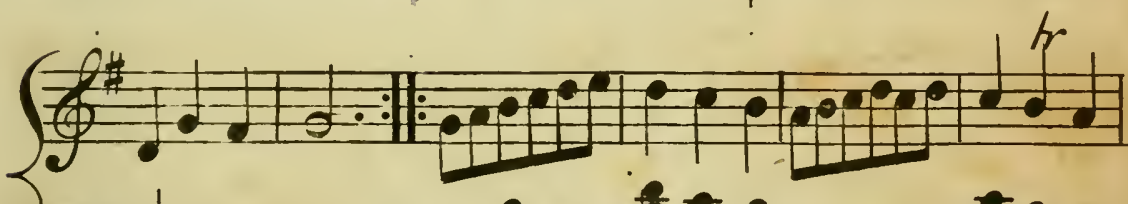
एँ..

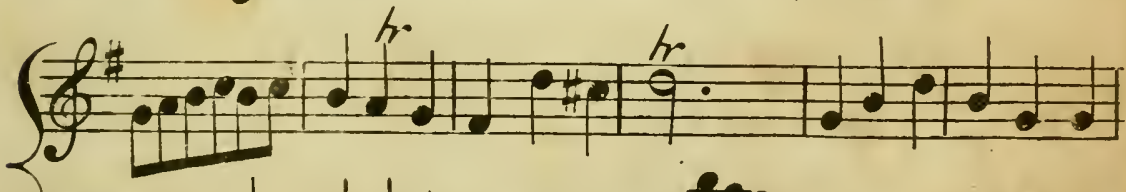

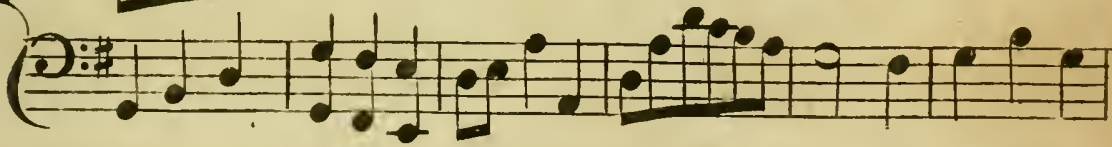

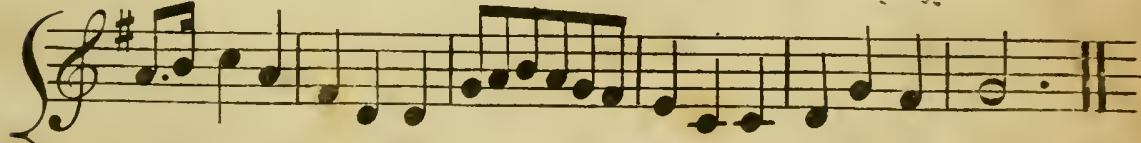

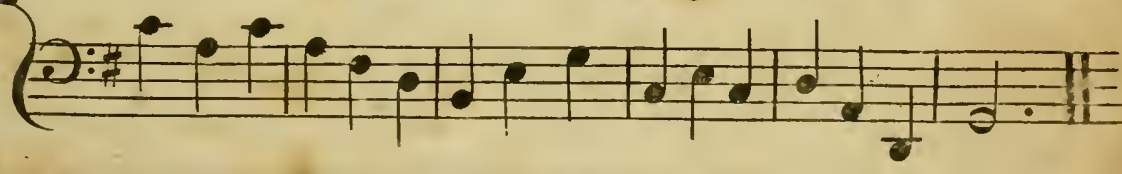


The break of Day. ho Toriad y Dydd. $\{$ Andante

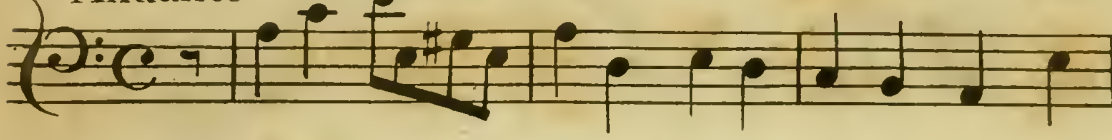

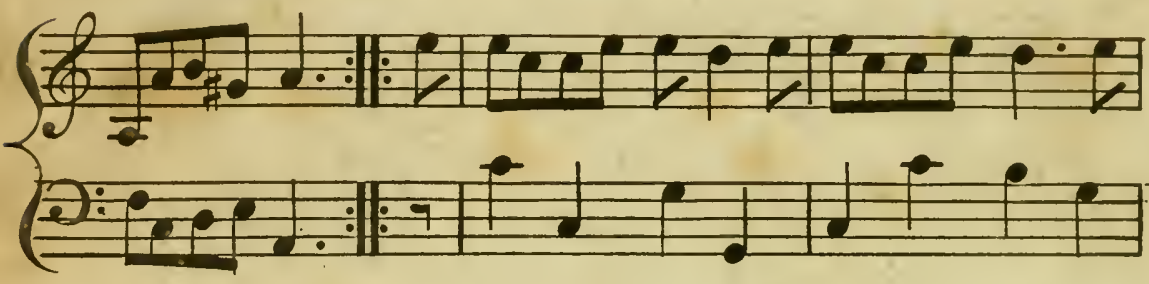

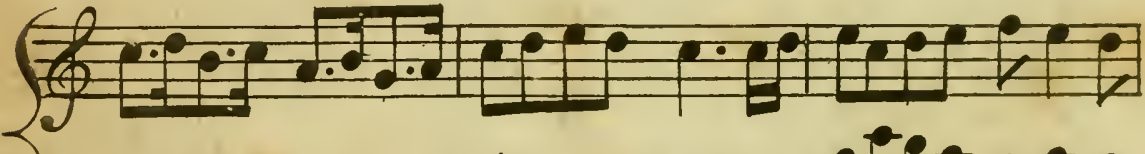
एव:

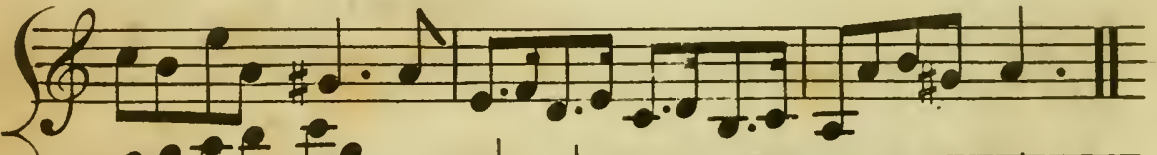

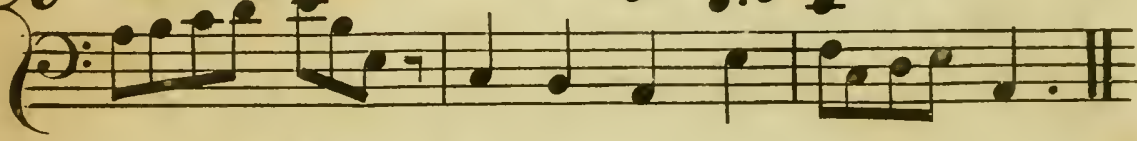
$\frac{\text { All Night long. }}{9}$

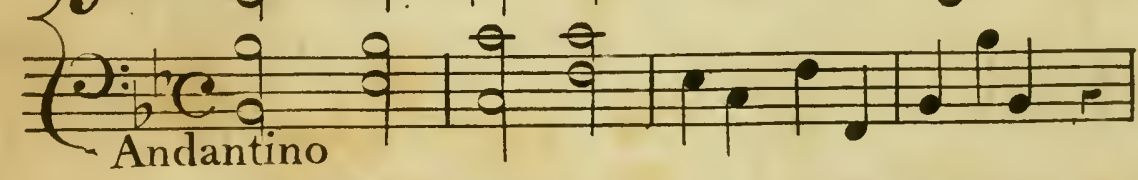

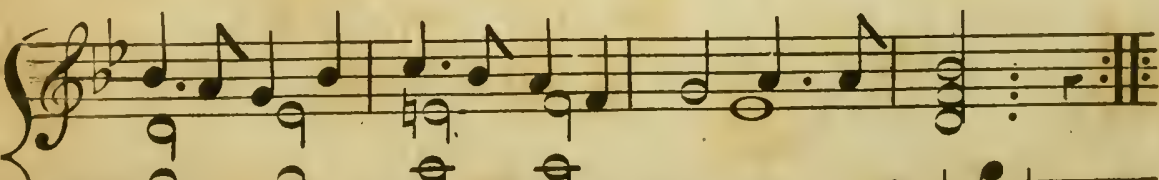
a) 
(b) (2)

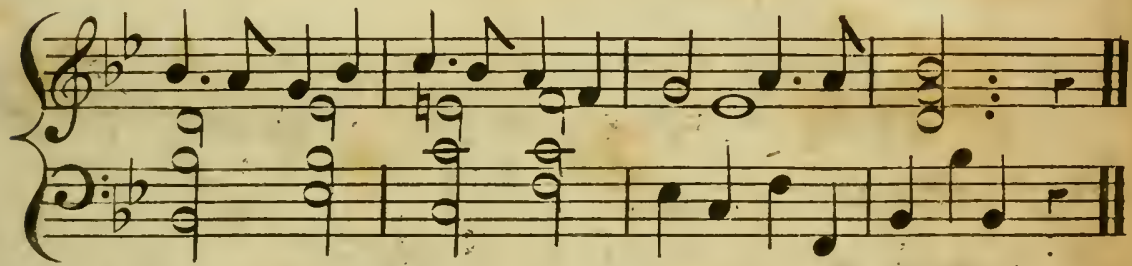
New Years Gift. Nôs Galan .

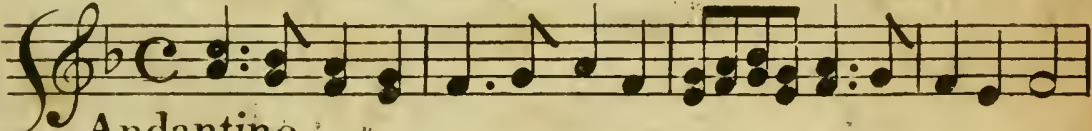
Andantino

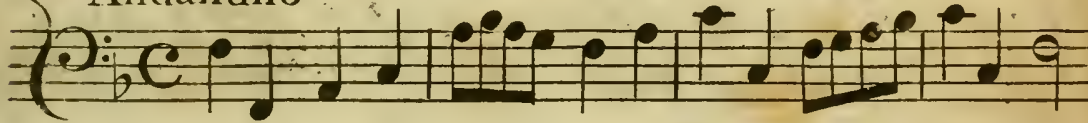

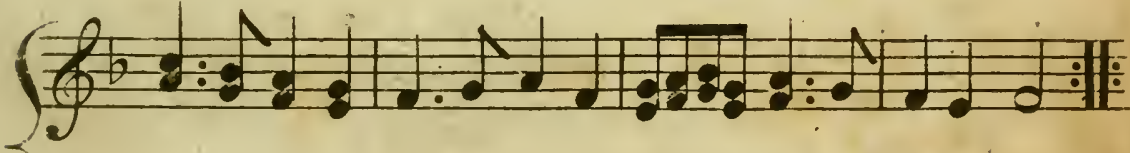

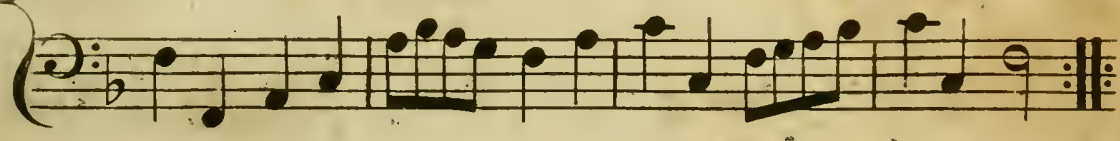

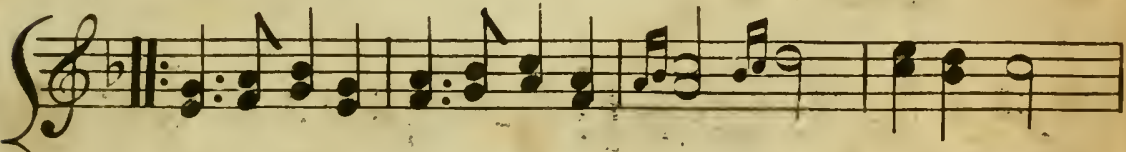

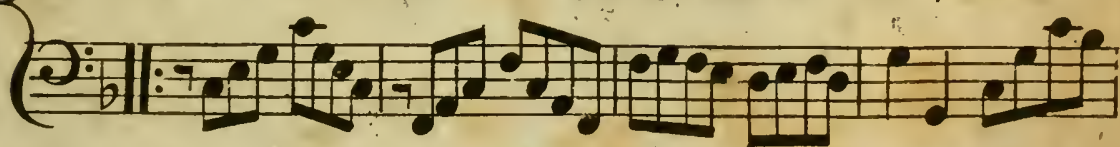

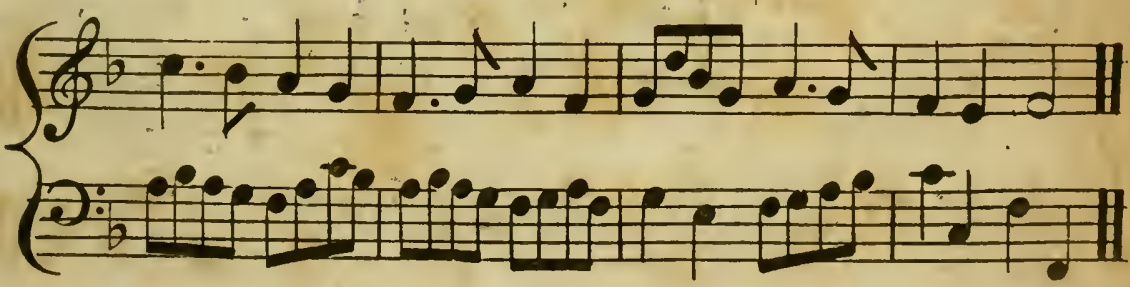


The rising of the Lark. Codiad yr Hedydd .

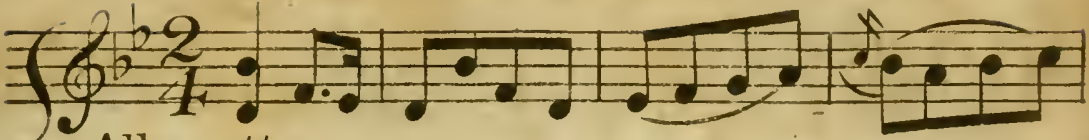
Allegretto

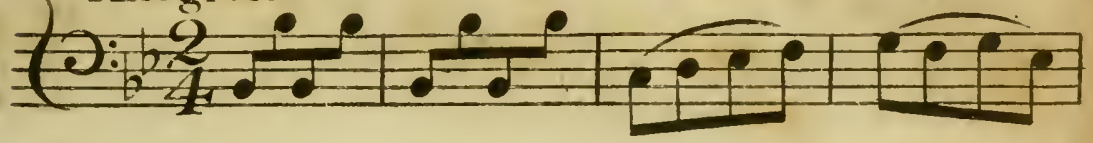
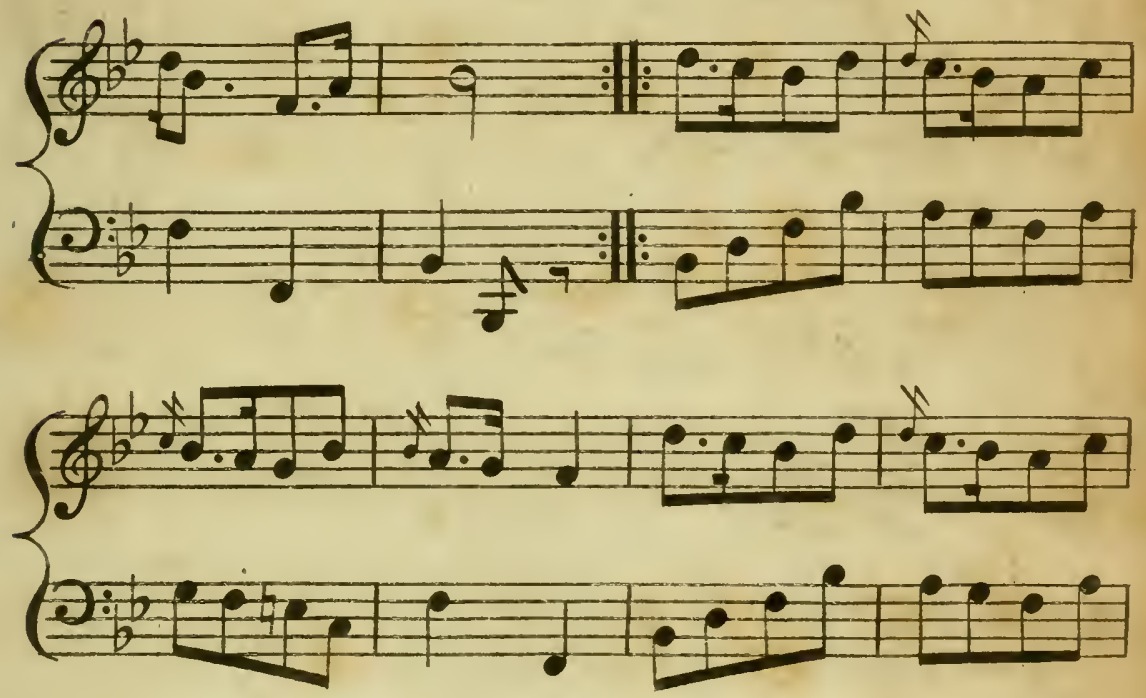

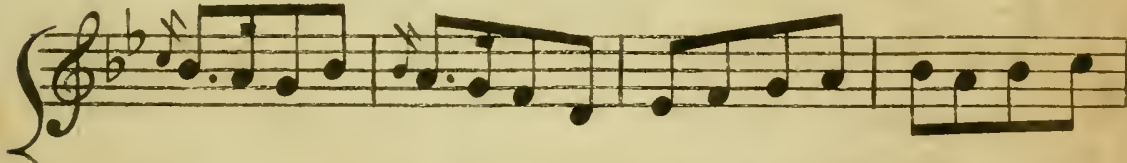
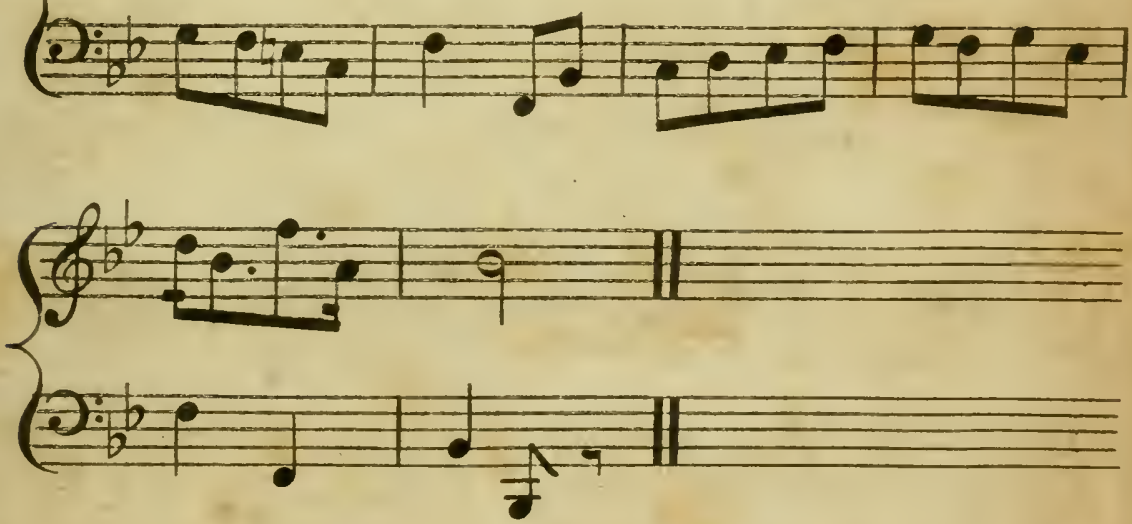


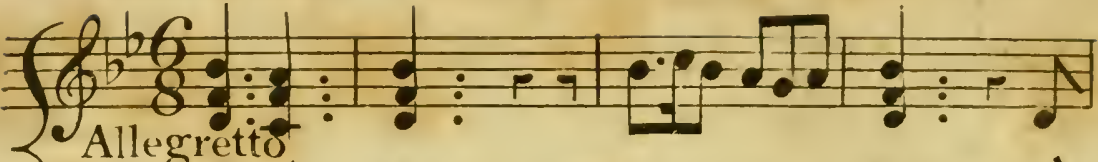

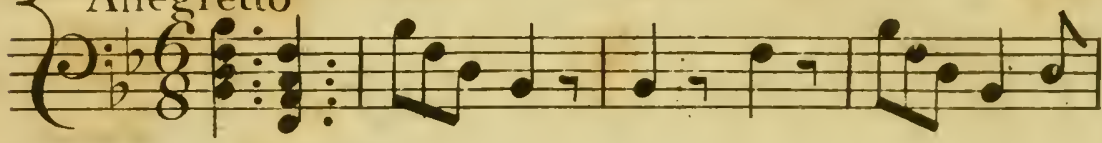

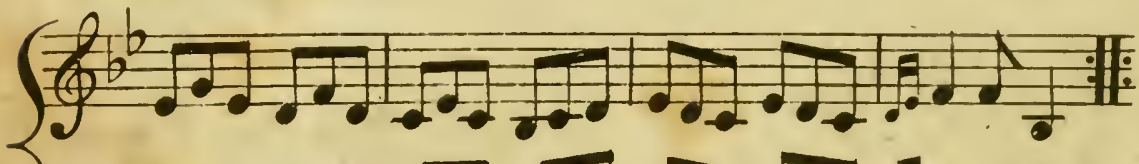

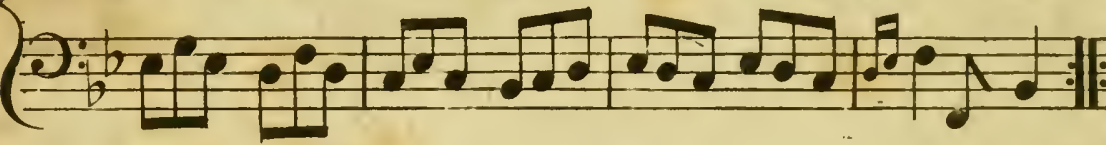

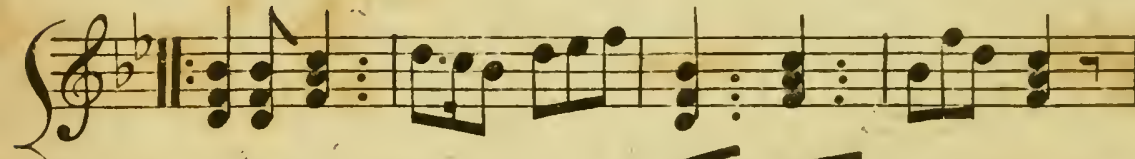
Q

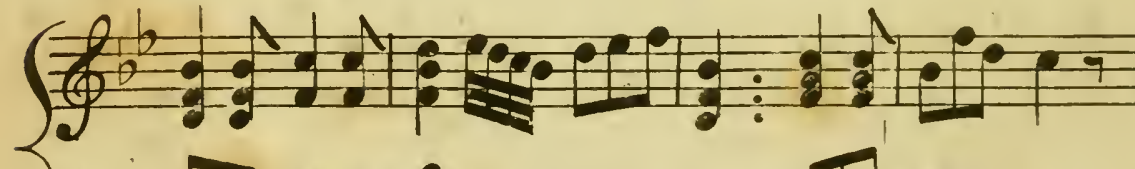

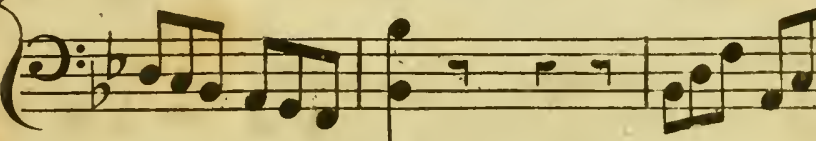

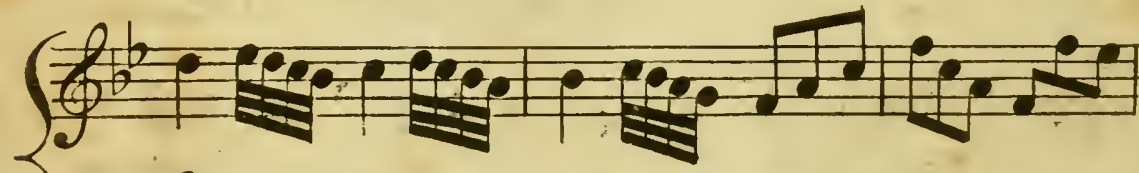

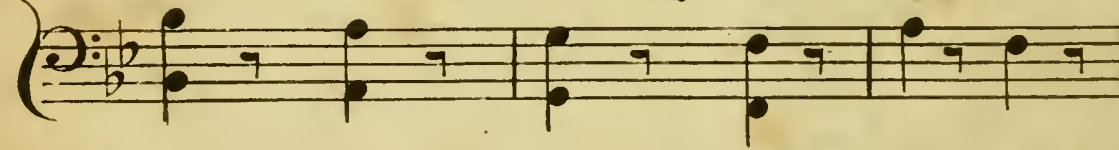
2

(8)

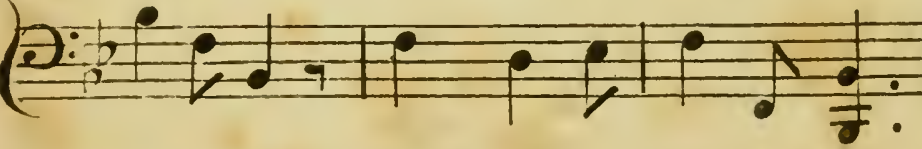




\section{G U I D E}

THROUGH ,

\section{NORTH WALES}

IN THE ROUTE OF THE PRECEDING TOUR.

** At the inns marked with an afterik *, poft-chaifes and horfes are kept.

THE DISTANCE FROM CHESTER TO CAERNAR. VON, ALONG THE USUAL ROAD, (NOT GOING BY FLINT,) IS ABOUT iz MILES.

$A_{T}$ Chefter the tourift may find it worth his while to vifit and examine the cafle and walls, with the courts of juftice, the cathedral, St. John's church, and the rows. If he is an antiquarian, he will derive entertainment from examining the remains of the hypocauft, near the Feather's inn; and fome other relics of antiquity in the neighbourhood.

From Chester to Flint, the Distance is

$$
\text { I5 MiLes. }
$$

About 2 miles from Chelter crofs the Ellefmere canal, and foon afterwards enter the county of Flint.-At $4 \frac{x}{2}$ miles pafs the little village of Bretton.-The mountain on the left is called Warren mountain.-At $7 \frac{1}{2}$ miles, pafs Hawarden cafle, by the road fide, and then enter Hawar- 
den, a village containing a neat church, but little elfe deferving of notice. -2 miles beyond Hawarden, crofs $\mathrm{New}$ Inn bridge. In a copfe about a quarter of a mile to the right of this bridge, are the poor remains of Euloe cafte, not vifible from the road. $-1 \mathrm{O}_{2}^{\frac{1}{2}}$ miles from Chefter, crofs Pentre bridge; and 12 miles, enter the village of Northop. In Northop church there are two or three ancient monunents. - At this place the tourift who is defirous of vifiting Flint, muft leave the great Irin road, and proceed along a road in a direction nearly north, for about three miles $t$.

At Flint there is little worth fecing befides the remains of its caftle, the county gaol, and a large fmelting-houre for the lead ore obtained in the neighbourhood. The inn is the Royal Oak, by no means good. No poft-horfes are kept here.

\section{From Flint to Holywell, $5 \frac{1}{2}$ Miles.}

Two miles from Flint is Bagillt; $-3 \frac{1}{\frac{1}{2}}$, Wallwine turnpike; -and $5 \frac{1}{2}$, Holywell. This is a very unpleafint road, notwithltanding its lying along the bank of the river Dee, here almoft three miles acrofs.

At Holywell the tourift will of courfe vifit St. Wenefred's well; from which the place derives its name. In feveral mills on the ftream that proceeds from this well, he may fee the different proceffes in the preparation and manufacture of lead, calamine, copper, brafs, and cottons. About a mile and a quarter north of the town, are the ruins of Bafing werk abbey. - The principal inn at Holywell is the White Horfe: * this is a good, but very extravagant

+ On the regular road, the following are the diftances:-12 miles from Cheiter, pafs the hamlet of Halkin; - and $18 \frac{1}{2}$, enter the town of Holywell.

houfe. 
houfe. Polt-chaifes and horfes may be had here, as this town is made the firft ftage-town from Chefter.

\section{From Holywell to St. Asaph, io Miles.}

About a mile beyond Holywell, on an extenfive common, are the lead mines.-At $2 \frac{1}{2}$ miles fee on an eminence, at a diftance towards the right, a high circular tower, fomewhat like an old windmill; this is fuppofed to have been a Roman pharos.-About 7 , or $7 \frac{1}{2}$ miles, defcend into the vale of Clwyd. From the fide of the hill there is a very extenfive and beautiful profpect; -Denbigh, at a diftance on the left, St. Afaph in front, and Rhyddlan caftle on the right, with all the varied fcenery of the vale.-10 miles, St. Afaph.

At St. Afaph are a cathedral, bihop's palace, and deanry.- - The tower of the cathedral commands an extenfive view along the vale. The inn is the White Lion *, a good houfe.

If the tourift withes it, he may make the two following excurfions from this place; in the latter, however, he will have but little amufement.

I. Excurfion from St. Afaph to Denbigh, 6 Miles. - The road lies entirely along the vale of Clwyd, but it is fo low, as to afford few good profpects. - At three miles pafs a woody dell that prefents a pieturefque fcene on the right of the road. -6 miles, Denbigh.

See the caltle, a fine ruin. - The antiquarian would vifit Whitchurch, the parin church, about a mile diftant, to fee the monuments of Humphrey Llwyd, the antiquary, and fome of other celebrated perfonages.-There are two principal inns at Denbigh, the Crown and the Black Bull *. The latter is by much the moft comfortable houfe of the two. 
2. Excurfon from St. Afapb to Rbyddlan, 3 Miles.-This road lies alfo along the vale of $\mathrm{Clw} y d$, and, about a mile from St. Afaph, affords a good view of the little city.

At Rhyddian there is the theil of a cafle. No accommodations are to be had at this place, but what a very paltry public-houfe can afford.

From St. Asaph to Conway, i $8 \frac{1}{2}$ Miles.

Four miles from St. Afaph, on the right of the road, is Kinmael, the feat of the reverend Edward Hughes, one of the proprietors of the Anglefea copper mines.-At $4 \frac{3}{7}$ miles pals the village of Llan St. Siôr, or St. George's; and $\sigma_{\xi}^{\prime}$, Abergeley. At Abergeley there is a tolerably good inn, at which port-horfes are kept. - At $9 \frac{1}{4}$ miles pars Llandulas; and at 8 miles arrive at Conwy ferry-hnufe*. The river is fomewhat more than half a mile acrofs, and muft be paffed in a boat.

At Conwy the tourift may examine the cafte, tan ancient manfion, called $\mathrm{P}$ âs Mawr, $\rightarrow$ the poor remains of the abbey,-and the church. The moft comfortablenipis is, the Harp*.

From Conwy the two following very pleafunt excurfiows mixy be made.

1. Excurfon from Conwy rand the Greidldin, in the rubole about 18 Miles. - This excurfion cannot be performed any way fo well as on fout. Crofs the ferry, and proceed to Teganwy, the feat of Mrs. Williams, near which are the poor remains of Diganwy caftle, about a mile and half north of the ferry-houfe.-Continue the route along the weft fide of the promontory to Gogarth, a ruined palace of the bihops of Bangor, ahout 6 miles from the ferry.F.xamine the high rocks that form the northern extremity of the Great Ormes Head,-and return by Gloddaeth and 
Bodfcallon, two elegant feats belonging to fir Thomas Moftyn, bart.

2. Excurrfon along the Vale of Convuy to Caer Rbuin, and the Waterfall, about 8 Miles; $-\Lambda$ mile from Conwy pass the village of Kyflin.-At $5^{\frac{1}{2}}$ miles is Caer Rhûn, where there are confiderable remains of the Conori:um of the Romans. In a mountain weft of the road, and vifible from thence, 13 miles beyond Caer Rhûn, is the grandeft cataract perhips in Great Britain. It is near a bridge called Pont Dolgarrog, under which its waters flow, and it is called by the country people Rhaiadr Mawr.

From Conway to Bangor Ferry, i $6_{\frac{1}{2}}^{\frac{1}{2}}$ Miles.

About 3 miles from Conwy, defcend along the tremendous hoilow of Sychunt; and about 5 miles, pafs the mountain Penmaen Mawr.-At 7 miles is the village of Llanfair Vechan; and 9 miles, that of Aber. Near the bridge at Aber there is a mound on which once ftood a houfe belonging to the princes of Wales; arid, at the diftance of about two miles, at the extrenity of a highly romantic vale, is a cataraft well worth vifiting. At Aber there is a fnall, but comfortable inn. -13 miles from Conwy is the village of Llandygai. The church contains a monument to the memory of archbihop Williams. $-13^{\frac{2}{2}}$ miles is Penrhyn cafte, the feat of lord Penrhyn. -15 miles is the city of Bangor; - and $16 \frac{1}{2}$, Bangor Ferry.

At Bangor the cathedral is worth vifiting.

The inn at Bangor Ferry* is a very good one.

From Bangor Ferry a very pleafant excurfion may be made to lord Penrbyn's fate quarries; the romantic -vale called Nant Frangon; the waterfalls of Benglog; Llyn Ogwen, and Llyn Idwel. The whole route would be about 26 or 28 miles, but the greateft part of it may be performed in carriages, 
carriages, or on horfeback. - There is through Nant Frangon a carriage road through the village of Capel Curig to Llanrwit.

\section{Prom Bangor to Caernarvon, 9 Miles.}

The road affords fome fine views of the Rraits of Menai, and the furrounding country.

At Caernarvon the tourift will of courfe vifit the caftle. -From the rock behind the hotel, and from the Eagle tower of the cafle, are very extenfive views. - Half a mile fouth of Caernarvon is Llanbublic, the parith church, near which are to be feen fome remains of the Roman Segontium. -The Hotel + at Caernarvon is, without any exception, the beft and moft comfortable inn in North Wales.

From Caernarvon, as a centre, various excurfions may be made.

1. To the village and lake's of Llanucris, about to miles diftant *. Here is one of the moft romantic vales in the kingdom; and about three miles beyond it, one of the rudeft mountain paffes that inagination can paint. Near Llanberis are the oid tower of Dolbadarn caftle, and a fine cataract called Caunant Mawr; and, on the bank of the upper lake, a copper mine. On the left of the village are the mountains Glyder Vawr and Glyder Bach, in whofe vicinity nearly all the $W$ elfh alpine plants are found. On the right of the vale (and the fummit about $4 \frac{1}{2}$ miles

+ This excurion camot be performed in carriages further than Cwm y Clo, the foot of the lower lake, whence a boat may be had to take the tourit up the lakes. This boat fhould be ordered the preceding day.-A pedeftrian may perform the journey without the aid of a boat, as may alfu a perfon on horfeback. 
diftant from Dolbadarn caftle), is Snowdon. From hence the afcent is fo gradual, that a perfon, mounted on a ftrong Welth poney, may ride very nearly to the fummit.

From Llanberis the excurfion may be varied by going through the above romantic pafs called $\mathrm{Cwm}$ Glâs, into the beautiful vale of Nant Hwynan, and thence to Beddgelert; but, as this excurfion would occupy in the whole near 30 miles, it could not conveniently be performed in one day on foot; on horfeback, however, there would be little difficulty. This excurfion, in its feries of grand and romantic fcenery, is fcarcely exceeded in any other parts of Great Britain.

From Llanberis there is a horfepath to Capel Curig, whence the tourift will find a tolerably good carriage-road to Llanrwit.

2. From Caernarason to the Summit of Snowdon, by Dolbadarn caftle, the diftance is about 12 miles. The chief part of this excurfion may be performed on horfeback.There is another track fomewhat nearer by Llyn Cwellyn, in the road to Beddgelert.

3. From Caernarvon to Lbanraft, returning by the Vale of Ffeftiniog, Tanjbrulch, and Beddgelert; the Difance in the wubole about jo Miles. This excurfion cannot be conveniently performed except on horfeback. The tourift may go either by Llanberis, or the vale called. Nant Frangon, to Capel Curig, where he will find another beautiful vale, and two lakes. The inn at this place affords excellent accommodation, confidering that it is fituated in the interior of the mountains. Many perfons remain here a few days to enjoy the fine fcenery of the neighbourhood, and to amufe themfelves in angling for trout, with which the lakes and all the ftreams of the vallies abound. In his journey from Capel Curig to Llanrwit, the antiquarian would probably 
probably choofe to vifit Dolwyddelan caftle, a Britih ruin, three miles on the left of the road.-About 5 miles from Llanrwit is the celebrated cataract of the Llugwy, Rbaiadr y Wenol. A mile beyond this is the picturefque bridge called Pont y Pair, near the village of Lettws y Coed.

Near Llaurwft is the aucient manfion of Gwydir, once the family feat of the Wynnes, and now the property of the right honourable lord Givydir.-Llanrwit is chiefly celebrated for its fine bridge, built under the fuperintendance of Inigo Jones. The church, or rather the chapel adjoining to the church, is well worth a vifit from the tourift. The inn is the Eagles*, a good houfe.

In his return to Caernarvon, on the prefcribed route, the tourift, at 3 I miles from Llanrwit, will repafs the village of lBettws, from whence leaving the former road, for that leading to Penmachno, he will at 5 and 6 miles pafs two cataracts of the river Conwy, the former, however, not a very confiderable one: the latter, which is called Rbaiadr y Craig Llavgd, is a little to the left of the road, ncar a fmall fulling mill, Pandy, in Welh. -8 miles from Llanrwit he will pafs through the village of Penmachno, and $\delta$ miles farther, after a very uninterefting ride over mountainous moors, will enter the village of Ffeliniog. Here there is a very uncomfortable public houfe. Near Ffeftiniog are the catarants of the Cynfael. $A$ mile from the village he will enter the vale of Ffeftiniog, and pass along it nearly to Tanybwlch, which is about 20 miles from Islanrwh. From Tanybwlch to Caernarvon, the tiftance is 22 miles farther. The inn at Tanybulch $*$ is a very comfortable houfe. -8 miles, crofs Pont Aberglâsllyn:-10 mules, enter Beddgelert:-i 4 , pafs Llyn Cwellya :- i 7, Bettws Garmon: and 22, enter Caernarion. 
4. An excurffon may be made on foot or on horfeback, about 23 miles, fiom Caernarvon to the Pools called Llynian Nantlle, and the flate quarries near Lianllyfni. This part of the country is very fine.

5. Or from Caernarven to Prullheli, diftant 20 miles, returning by Criccieth and Beddgelert, in the whole about 58 miles. This, however, may not be interefting to many tourifts; and very $f e w$ would think their trouble repaid in vifiting the extreme parts of the promontory.

6. Excurfions on the valcr may be made, with a fair wind, to any of the adjacent parts of Anglefea. The fail up the ftraits of Nienai, to Prieftholme ifland, is extremely pleafant in fine weather: A fnall decked cutter, capable of accommadating ten or twelve perfons, may be had of the innkeeper of the hotel. The charge, with two perfons to manage it, is a guinea a day.

7. Excurfion from Caernareon to Holykead, the copper mines, and Beaumaris, in the wulole about 90 Miles. - Crofs the Merai at Moel y Don ferry, 5 miles from Caernarvon.About a mile from the ferry-houfe, on the Anglefea fide, is Plâs Newydd, the beautiful feat of the earl of Uxbridge. Near the houre are two cromiechs, and an ancient tumulus.-At 8 miles from $C_{2}$ ernarvon pafs the village of Llandaniel;-I I, Llanvihangel; $-14 \frac{1}{2}$, Liangefni; and 20, arrive at Gwyndy *. Here there is a good inn, the end of the firft ftage from Bangor to Holyhead.-From Gwyndy it is $3 \frac{3}{4}$ miles to Bodedern; -5 to Llanygenedl; $-8 \frac{1}{4}$ to the Holyhead ifland; - and 12 to Holyhead.

There is little remarkable in Holyhead, except the fituation of the church and church-yard.

The diftance from Holyhead to Amlwch is about 20 miles. The copper mines are about a mile from Amiwch. VOL. II.

is

There 
There is no good inn at this place. Ty mawr, appeared the beft, but the accommodations were only tolerable. Two miles eaft of Amlwch is the fingular churcls of Llanellian.

From $A$ mlwch to Beaumaris the diftance is about $2 a$ miles. Six miles from $A$ malwch pals the extremity of Dulas bay.-At 12 miles pafs Red Wharf bay.-And I3, the village of Pentraeth. The church of this village Mr. Grofe thought fo picturefque as to deferve a place in his work on the Antiquities of Britain. Near Pentraeth is Plâs Gwynn, the refidence of Paul Panton, efq. but chiefly known for its excellent library of Welh MSS.

The only obję worth notice in Beaumaris, is the caftle. Three quarters of a mile weftward is Baron hill, the feat of the right hon. lord Bulkeley.-About a mile north is Friars, the feat of fir Robert Williams bart.; and near it a barn built from the ruins of Llanvaes abbey.-Three miles beyond Friars, are the remains of Penmon priory; and juft off this corner of Anglefea, is the ifland of Prieftholme, celebrated as the refort of various fpecies of fea fowl.-The principal inn at Beaumaris is the Bull's Head, a comfortable houfe.

In his return to Caernarvon, the tourift may either crofs from Beaumaris immediately over to the village of Aber, in Caernarvonhire, or he may crols the Menai at Bangor ferry. The latter is preferable.

\section{From Cafernarvon to Beddgelert, the Disq TANCE IS I 2 Miles,}

Half a mile from Caernarvon, pafs the remains of Segon. tium, and Llanbublic church. -Three miles on the left the woods of Glangwnna, the houfe of T. Lloyd efq. Five miles the village of Bettws, - Six and a quarter 
on the left Plâs y Nant, a houfe belonging to fir Robèrt Williams, bart.; and on the right a fmall cafcade at Nant mill. The high mountain on the right is called Mynydd Mawr, and that on the left, Moel Aelir.-Seven miles, Llyn Cwellyn. See Snowdon on the left; its fumnit may be afcended from hence. The tourift who winhes to - xifit Llyn y Dywarchen, the pool containing a fmall floating inland, muft afcend to the mountain hollow on the right, foon after he has paffed Llyn Cwellyn.

At Beddgelert there has been lately erected a very comfortable inn called the Beddgelert Hotel. The diftance from Beddgelert to Pont Aberglàllyn (the devil's bridge) is about a mile and a half. - From Beddgelert the tourift may afcend to the fummit of Snowdon: the diftance about 6 miles. He mould by all means vifit the vale called Nant Hzuynan, one of the moft beautiful in Wales. In this vale, one mile and a half on the left, is Dinas Emrys, the place from whence the prophefies of Merlin are fuppofed to have been delivered. Two miles, Llyn y Dinas. - Four and a half Llyn Gwywant: in a mouptain on the left of the path a little beyond this pool, is a cataract called Rbaiadr y Crum $D y$ y. There is a horfe-path through this vale to Capel Curig, and Llanrwft.

\section{From Bedpgelert to Tanybwlch, ro Miles.}

One mile and a half, Pont Aberglâflyn. - The new road from hence is exceedingly good, and affords many very beautiful profpects.

The inn * at Tanybwlch, is a fmall but comfortable houfe, ftanding on an eminence that overlooks the vale of Ffeftiniog. - Not far from the inn is Tanybwlch hall, the feat of - Oakley, efq. - The village of Ffentiniog is about 3 miles diftant, near which are the cataracts of the Cyrfael: the road to the village lies along the vale.

\section{A 2}


From Tanybulch to Harlech, 10 Miles.

Crofs the vale of Ffentinog. - One mile the village of Maentwrog. - One mile and a half, having croffed a fmall bridge, there is, about a mile and a half on the left of the road, a cataract called $R$ haiadr $d \hat{u} \cdot-4$ miles Llyn Tecwyn wcha. -5 miles Llantecwyn. $-5 \frac{x}{2}$ Llyn Tecwyn ifa. $-7,-$ Pont y Crudd; - and 10 Harlech.

At Harlech are the remains of a caftle. The public houfe is very fmall. It is kept by a civil man called Anwyi.

From Harlech a guide (John Richards) may be had to the romantic holiow, 4 miles diftant, called Cwm Bychan; and from thence round the ftill more romantic $B$ wlch Tyddiad, and Drws Ardudwy, in the whole about is miles.

From Harlech to Barmouth, 10 Miles.

One mile and $a$ half, the village of Llanfair. $-2 \frac{1}{2}$ miles Llanbedir. In a field on the right, near this village there are two upright ftones, probably what the Wellh of former times erected in memory of fome celebrated warriors. $5 \frac{3}{4}$ Llanddwye. $-8 \frac{1}{4}$ miles, Llanaber, the parih church of Barmouth; -and 10 miles, Barmouth.

There is a charming walk along the beach of the river near Barmouth. This place is fingular on account of many of its houfes being built up the fide of a lofty rock. The Corfygedol arms* is an excellent inn.

From Barmouth to Dolgelle, 10 Miles.

The 2 firt miles are along the beach, one of the moft beautiful rides in Great Britain. -8 miles, Llanellid turnpike. -10 miles, Dolgelle. 
The Golden Lion* at Dolgelle, is a tolerably good inn. From Dolgelle a guide may be had to afcend Cader Idris, whofe fummit is about 6 miles diftant.-2 miles north of Dolgelle, are the remains of $y$ Vaner or Kemmer abbey; and 4 miles beyond, on the left of the road leading to Tanybwich, is Dolmelynllyn, the feat of W. A. Madocks efq. and near it the cataraet of the fame name. -3 miles beyond Dolmelynllyn, are the cataracts, $P_{i} / f_{y} l l y$ Cain, and Rhaiadr y Mawddach. It will be neceffary to take a guide in order to find the latter cataracts.

\section{From Dolgelle to Macirynlleth, 15 Miles.}

Five miles, Llyn Trigrainwyn, 'the pool of three pebbles,' celebrated for a fingular tradition refpecting it. -7 miles, a fmall public houfe, the Blue Lion, from whence a guide may be had to the fummit of Cader Idris, 4 miles diftant. The pool vifible from the houfe is Llyn Mwyngil. I4 miles crofs the river Dorey.

At Machynlleth, there is an old building, in which Owen Glyndwr, is faid to have affembied a parliament. The Eagles " is the beft inn.

From Machynlete to I.lantroloes, 9 Miles.

A bout half way betwixt thefe towns, and near one mile and a half on the right, there is a cataract calied Frrudy Pennant. - Plinlimmon is vifible at a diftance on the right. Iy miles, "crofs the Severn and enter Llanydloes.

The new inn * here is a very comfortable houfe.

From Llanydloes to Newtown, 3 Miles. $6{ }^{3}$ miles Llandinam.-13, Newtown.

The Bear* is the principal inn. - Dolforwyncafte is about 4 miles north-eaft of Newtown. $-I \frac{\pi}{2}$ mile from Newtown, 
near the road leading to Builth, is a catardot, but not worth vifiting.

From Newtown to Montgomery, 9 Miles.

At Montgomery the tourift will probably vifit the caftle and the church. - The Dragon * is a good inn.

From Montgomery to Welsh Pool, 9 Miles.

$7 \frac{1}{2}$ miles pars on the left Powys Cante.

The Oak* is the principal iun at Welfh Pool.

\section{From Welsh Poor. to Oswestry, 5 Miles.}

6 miles, pafs the Breiddin hills, on the right. -9 miles, crofs the river Virumy in a boat. $\rightarrow \frac{x}{3}$ enter the village of Llanymynech. The Crols keys, a fmall inn in this village, is kept by Mr. Robert Bugh, a very ingenious man, the engraver of both the copies of Mr. Evans's map of North Wales.- I $3 \frac{\pi}{2}$ miles, a houfe of Induftry.

At Ofweitry the tourit may vifit the church, St. Ofwald's Well, and the mount on which the cafle ftood. The principal inn is the Crofs keys*.

\section{From Oswestre to Wrexham, I 5 Til Mes.}

$5^{\frac{1}{2}}$ miles the village of Chirk. The tourift may vifit the church, containing fome tolerably good monuments in memory of the Middleton family; the aqueduct over the vale of Ceirog; and 2 miles diftant, Chirk caftle. -8 miles, New Bridge, near which the ficene is remarkably picturefque. - Io miles the village of Ruabon. Near this place is Wynnftay, the feat of fir Watkin Williams Wynne, bart. ( $5 \frac{1}{2}$ miles eaft of Ruabon, is the village of Overton, and g miles Bangor Ifcoed, where there was formerly the largeft monatery 
monaftery in Britain) $13 \frac{x}{2}$ miles from Ofweftry, on the right of the road to Wrexham; is Erddig, the feat of Philip Yorke, efq.

See the church at Wrexham; and in it a moft beautiful monument, in memory of Mrs. Mary Middleton. $-5 \frac{r}{2}$ miles N. E. of Wrexham is Holt, where are the poor remains of a cafte.-There are two good inns at Wrexham, the Eagles* and the Red Lion, * the former however is ufually thought the bett houfe.

\section{From Wrexham to Mold, I $2 \frac{T}{2}$ Miles.}

$+\frac{i}{2}$ miles Cegidog bridge. $-5 \frac{x}{2}$ the village of Caergwrle, near which are the remains of a cafle. -6 , Hope.-12, Mold.

The tourift may vifit Bayley hill, on which the caftle Atood, and the church.-I $\frac{x}{2}$ mile, north-weft of Mold; is Rhual, the feat of the Griffith family, near which is Maes Garmon, where in 448 , the famous Alleluia viEtory was obtained by the Britons over the Picts and Scots.The inn at Mold is the Dragon, a bad and extravagant houre.

From Mold to Ruthin, $8 \frac{i}{2}$ Miles.

At Ruthin are the remains of a caftle. - I forget the fign of the inn*.

From Ruthin to Llangollen, $13 \frac{\text { T Miles. }}{2}$.

About $10 \frac{1}{2}$ miles enter the vale of Crucis. $-11 \frac{\pi}{2}$ pafs the pillar of Elifeg, in a meadow on the left of the road; and $\frac{1}{4}$ of a mile beyond it, on the fame fide, the remains of Valle Crucis abbey. Caftell Dinas Brân is vifible on an eminence behind the abbey.

The principal objects worth vifiting about Llangollen, are, Valle Crucis abbey, and the pillar of Elifeg, Caftell 
Dinas Buin; and the vale of Llangollen. It is a pleafan: morning's ride of about 10 miles, round the vale. Near l'ont y Cyflyllte, 4 miles from the town (at the end of this. ride), the tourift will fee an immenfe aqueduct for the Ellefmere canal, over the vale, and the river Dee.- The princinal inn at Llangollen is the Hand*, where perfons in general complain of bad fare and attendance.

\section{from llangollen to Corwen, io Miles.}

About the third mile-ftone, fee, on the oppofite bank of the river, Llandyfilio hall. -7 miles, the fite of Owers Glyndwr's palace:

$5 \frac{\pi}{2}$, miles weft of Corwen, on the road leading to Llanrwit, is Pont y Glyn, with a fine cataract beneatb it; and $2 \frac{1}{2}$ miles fouth, near one, of the roads to Bala, and behind the village of Cynwyd, is a cataract called Rbaiad Cynwyd.-On the hill oppofite to the town, there is a greas circle of ttones, called $Y$ Caer Wen.-The New Inn *, the fign of Owen Glyndwr, is the only one in the place.

Trom Corwen to Bala, the Distance is 12 Mires.

Near Bala, the principal curiofities are the lake, and ¿wo mounts on different fides of the tow' $n$, on which there have been britint forts. - It is a pleafant excurfion of about 13 miles, on foot or horfeback, "to go round the lake. Crofs the bridge at the north-eat corner, and proceed along the eafterm bank.-- 4 miles, the village of Llangower. - G miles, crofs the river Twrch, and fee the immenfe ftones carried by the lleam in a thunderform, in June $5781,-78$, the villag of IJanwchllyn. A mile begond this place there was an ancicut Britih fort called Caftell

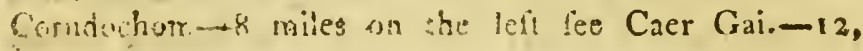
Llanycil, 
Llanycil, the parion churci to Bala.-The Bull* is by much the moft confortable, though not, perhaps, the head inn in this town.

From BAEA TO THE VILLAGE OF LLANRAAIADR; in Montgomeryshire, 5 Mires.

I $\frac{2}{2}$ miles, crofs Pont Cynwyd.-2 miles, Rhiwedog.7 , a pals over the mountains, called Millter Gerrig;: $0 \frac{1}{2}$ miles, the village and vale of Llangynog;- 5 miles, I.lanrhaiair.

The celebrated cataract called Pifyll Rbaicadr is about $4 \frac{t}{2}$ miles north-weft of the village. - At Llanrhaiadr there is a fmall public houfe, the Coach and Horfes, where one bed may be had, and perhaps no more.

From Llainhaiadr to SHrewsbury, 26 Miles.

About $3 \frac{1}{2}$ miles from Llanrhaiadr are the village of Llangedwin, and Llangedwin hall, the latter one of the feats of fir Waikin Williams Wynne, bart.;-8 miles, Llanyblodwel;-10, Llanymynech;-I 4 miles, Knochin;-1 8 miler, Neffcliffe ; -22, crofs Montford bridge.

At Shrew foury the tourift will find amufement in vifiting the caftle; the remains of the walls; the gaol; the abbey: the churches, particularly St. Alkmunds, in which there is, a beautiful painting on glafs, the performance of Eginton of Birmingham; the Quarry; the houfe of induftry; the remains of the three houfes of Auguftine, Francifan, and Dominican friars; the free fchool, and fome other publis buildings. 



\title{
FIORA $A^{-} C A M B R I C A$ :
}

$A$

\author{
SYSTEMATICAL CATALOGUE
}

OF THE

\section{MORE UNCOMMON WELSH PLANTS,}

\author{
เพI' $\mathrm{TL}$ \\ THEIR PLACES OF GROWTH, \\ A ND
}

TIAES OF FLOTERING.

* * Where the places in the enfuing Catalogue are not fully dicfcribed, reference may be made to the Index, and thence to forne other part of the work.

\section{Explanation of the References.}

Smith. Flora Britannica, auctore, Jacobo Edwardo Smitk M. D. 8vo. vol. 1. and 2. 180o.-Eng. Bot. Englifh Botany, by Dr. Smith, and Mr. Sowerby, vol. I-I 2.-Witk. Arrangement of Britifh Plants, by Willian Withering, M.D. 4 rol. 8 vo, 1796.- Éuds. Gulielmi Hudfoni, Flora Anglica, 8vo. 1798 .

\section{CLASS I.}

\section{MONANDRIA.- MONOGYNIA.}

Saticoria herbacea. Mar, Samphire.-Smith, 3.-

S. antiki. Eng. Bot. 4I5.-S. europea. Hudr. 1.-A or

B. Augut, September.

On fea-fhores, generally in a muddy foil, overflowed by the bigh tides, common. 
Hippouris Vulgaris. Mare's Tail._Smith, 4.-Eng. Bot. $7 \sigma_{3} .-\mathrm{P}$. May.

In feveral ditches in the iffe of Anglefea; and in ditch about a hundred yards north-weft of Rhyd marth, near Preftatyn, on the fea-coan of Flint Thire.

Chara flexilis. Smooth Chara.-Smith, 6.-A. July, Auguft.

In a pool called Llyn Aled, in the parift of Llänfannan, Denbighfhire.

Zostera marina. Grafs-wrack.-Smith, 7.-Eng. Bot. 467.-P. Aug.-Sept.

Salt water ditches, not uncommon.

\section{CLASS II. \\ DIANDRIA. - MONOGYNIA.}

Ligustrum vulgare. Privet.-Smith, 12.-Eng. Bot. 764.-S. June, July.

Hedges in various parts of Anglefea, and about Orme's Heard.

Verontca spicata, Spiked Speedwell--Smith, 15.Ing. Bot. 2.-P. June, July.

Gloddaeth, near Conwy; - the hill of Diferth cafte in Flinthire;-and on Penmaen Mawr.

Weronica hybrida. Welfi Speedwell. Smith, 16.-Eng. Bot. 673.-P. July.

On Craig Breiddin, (or as it is fometimes written, Craig $W^{\text {Treidhin }}$ ) a mountain about eight miles north-ealt of Wein Pool. 
Veronica officinalis. Common Speedwell.-Snith, 16. Eng. Bot. 765. -P. May-Aug.

Sides of roads, and in dry fterile ground, common.

Veronica scutelifata. Narrow-leaved Mar/h Speedwell. Smith, 21.-Eng. Bot. 782.-P. July, Auguit.

Marfty ground in Anglefea, not uncommon.

Veronica montana. Mountain Specdruell.-Smith, $2 \mathrm{I}$. -Eng. Bot. 766.-P. May, June.

In the upper wood at Tower, near Mold, Flinthire; and near the rivulet in Garn Dingle, three miles north, wẹt of Denbight.

Pinguicula vulgaris. Conmon Butternoort, or Rot-gra/so -Smith, 27-Eng. Bot. 70.-P. May, June.

In bogs on all the moors.

Utricularia vulgaris. Hooded Milfoil.-Smith, 28.Eng. Bot. 253. -P. July.

In ditches and ftanding waters in Anglefea, not uncommon. Salvia pratensis. Meadow Clary.-Smith, 30.-Eng. Bot. 153.-P. July.

In dry meadows near Llanidan, in Anglefea.

Salvia verbenaca. Wild Englifb Clary.-Smith, 31.Eng. Bot. 154.-P. June-Oetober.

In Rhyddlan church-yard, Flinthire; - -and in various places about the Great Ormes Head.

\section{$=$ \\ CLASS III. \\ TRIANDRIA.-MONOGYNIA.}

Valeriana RUbra. Rad Valerian.-Smith, 37--P. June -September.

Near Llanidan church, Anglefea. 
Iris foetridissima. Stinking Iris.-Smith, 42.-Eng. Bot. 596i.-P. June.

Near the building on Prieftholme ifand, in plenty.

Schoenus compressus. Comprefed Bog-ruß.-Smith, 44. - Eng. Bot. 791.-P. July.

In a marh about a mile wett of Preftatyn, on the fea coaft of Flinthire.

Schoevus albus. White-headed Bog-ruß.-Smith, 46.P. Augurt.

In a bog weft of Dolbadarn caftle, near Llanberis.

SCIRPUS CFispitosus. Scalyjalked Club-rufh.-Smith, 49. -P. July.

Peat-bogs in Cwm Brwyog, near Llanberis.

Scirpus Maritrius. Salt-mark Club-rujh. - Smith, $j \sigma_{-}=$ Eng. Bot. 542.-P. July, Auguet.

In Saltney marn, and Rhyd marth, Flinthire.

Eriophorum vaginatum. Single-beaded Cotion-grafs:Smith, 53.-P. March, April.

In peat-bogs near Llyn Idwel, in Caernarronfhire, and Llyn Aled, Denbighfirire.

Eriophorum polystachion. Broad-leaved Cotton grafs.Smith, 59.-Eng. Bot. 563.-P. A pril, May.

In the fame places as the lait fpecies, but not fo frequently.

Eriophorum angustifolium. Common Cotton-grafs. Smith, 59.-Eng. Bot. 564.-P. April, May.

In peat-bogs among the mountains, fufficieutly common. 


\section{TRIANDRIA. - DIGYNIA.}

Phalaris arenaria. Sea Cumory-grafs. - Smith, 62.Eng. Bot. 222.-A. June.

Among the fea.fand near Newborough, Anglefea.

Phleum Pratense. Common Cat's-tail-grafs. - Smith, 68. P. June-October.

A variety of this grafs is found in Anglefea, with viviparous florets.

Milium Lendigerem. Panick Millet-grafs.-Smith, $76 .-$ Alop. ventricofus, Hudf. ed. 2. 28.-A. Auguft.

In the paftures caft of Merllin farm-houfe, in the parifh of Llanyfydd, Denbighthirc.

Agrostis minima. Sinalleft Bent-gra/s.-Smith, 82.-A. March, April.

In fandy paftures on the fouth-weit coalt of Anglefea, not uncommon.

Arra cristata. Crefted Hair-grafs.-Smith, 83.-Poa criftata. With. 145.-P. July, Auguft.

Barren paftures near Henllan, Denbighhire.

Aira flexuosa. Waved Mountain Hair-grafs.-Smith, 85.-P. July.

- On Crib y Ddefcil, a high rock near Llanberis.

AIR A P.REcox. Early Hair-grafs.-Smith, 87.-A. May, June.

Paftures on the lime-rocks near Henllan, three miles northwẹt of Denbigh.

Merica nutans. Mountain Melio-grafs.-Smith, 92.M. montana. Hudf. 37.-P. June, July.

In Garn Dingle, near Denbigh. 
Merica Cerviea. Purple Melic-grass.-Smith, 93.Eng. Bot. 750.-Aira carteleu, Hudr. 33-P. July, Augure.

In peat-hogs near I.lyn Idwel, Caernarronhise;-and on the Paris tnountain in Anglefea.

Melica uniflora. IVood Melic grass.-Sinith, 91.-P. May, June.

Not uncommon in woods and flady hedges.

POA RIGroa. Hard Meadew grafs. - Smith, 99.-A. June, July.

A mong the lime rocks near Henllan, Denbighthire.

PoA alpisa. Alpine Mleadow-grafs. — Smith, 100.-P. July.

This plant, and alfo a variety of it, with viviparous florets, is found ou the higher parts of Snowdon.

YOA CESIA? Sea-green AYcadow-grafs. - Smith, 103.P. glauca. With. 148.-P. June, July.

High mountains about Llyn Idwel and Llanberis;-and on Clogwyn y Garnedd, Snowdon.

Poa maritrima. Creeping Sea Meadow-gra/s._Smith, 97. -P. July.

On part of the falt-marh, a mile weft of Preftatyn, FlintShire.

Fistuca vivipara. Viviparous Fefoue grafs.-Smith, II 4. F. ovina, var. 4. With. 152.-P. June, July.

On the high mountains of Caernarvonßire, common.

Festuca rubra $\beta$. Welj Fefcue-grafs. -Smith, 116.F. cambrica. With. 156.-P. July, Auguft.

On the ledges of Clogwyn y Garnedd; -and among the higheft mountains about Llanberia.

FEsTUCA 
Festuca bromordes. Barren Fefcue-grafs.-Smith, 117 A. June.

About Denbigh caftle.

Avena pubescens. Dozuny Oat-grafs. -Smith, 140.-P. June.

Very common in the hedges about Garn, near Denbigh.

Arundo colorata. Canary Reed-grafs.-Smith, 147.Calam. variegata, With. 124.-P. July.

On the bank of the rivulet that runs by Dolbadarn caftle, into the upper Llanberis lake.

Arundo arenaria. Sea Mat-queed.-Smith, 148.-Calam, arenaria. With. I23.-P. June, July.

On the fand-banks on the fea-fhore, about Rhil marh, near-Rhyddlan; near Orme's Head; and near 'Towyn, in Merioneththire.

Rotbollia incurvata. Sea Hard-grafs.-Smith, 151.P. July, Augutt.

In Rhil marfh near Rhyddlan; but feldom obfervable on account of the fheep eating it quite clofe to the ground: it may, however, be readily detected on the turf banks in front of the cottages near the Stone houfe, which are formed of fods that have been taken from the marh.

Elymus arenarius. Upright Sea Lyine-grafs. - Smith, 152.-P. July.

Among the fand on the fea-coaft near the Orme's Head:

TRIANDRIA. - TRIGYNIA.

Montra Fontana. Water Cibickrveed.-Smith, 161.-A. April-July.

In fwampy ground, not uncommon.

VOL, II.

B B

CLASS 


\section{C.LASS IV. \\ TETRANDIA.—MONOGYNIA.}

Dipsacus pilosus. Small Teaft.-Smith, 169.-P. Aug.

On the left of the road leading from Newtown to Montgomery, about three miles and a half from the former place; - and near the forge, betwixt Wellh Pool and Ofwettry.

Gaitum boreale. Corofs.leaved Bed-frazu.-Smith, 180. -Eng. Bot. 105. -P. July.

On the ledges of the rocks near Tull Dû, above Llyn Idwel; - and about half a mile from Llanberis, among the gravel by the fide of the fecond rivulet, in the way to Llanrwit.

Rusta pereerina. Wild Madder.-Smith, $18 \mathrm{r}$.-Eng. Bot. 85 1.-R. tinctorum. With. 193.-P. June, July.

In the hedges at Gloddaeth, near Conwy.

Plantago maritima. Sea Plaintain.-Smith, 184.Eng. Bot. 175.-P. June, July.

In abundance on the fea-coafts. - Near Caergwrle cafte, Flint thire;--amonglt the rocks near Tull $\mathrm{D} \hat{\mathrm{a}}$, above Llyn Idwel; - and by the road-fide from Bangor to Holyhead, about two miles from $\mathrm{G}$ wyndy.

Plantago coronopus. Blick's-horn Plaintain.-Smith, 185.-A. May-November.

On all the fea.coafts, generally in a fandy foil.

Centunculus minimus. Small Chaff-rveed._Smith, 186. -Eng. Bot." 53r.-A. June, July.

In a piece of moit ground about a mile from Llanrwh, and within three or four yards of the turnpilse-road leading from thence to Coinwy. 
Aichemilla alpina. Alpine Lady's-mantle.-Smith, 190. Eng. Bot, 244.-P. July.

This beautiful plant is faid to grow on fome of the mouiltains of North Wales, but I have fought for it in vain.

\section{TETRANDRIA.-TETRAGYNIA.}

Potamorgeton granineum. Grafy Pond-queed.-Smith, 196.-P. July.

In the ditche of Rhyl marth, near Rhyddlan.

Ruppia maritima. Tafel Pond-zueed.-Smith, 199.Eng. Bot. 136.-P. July, Auguft.

In the falt-water ditches near Llanddwyn, in Anglefea ; and in thofe betwixt Traeth Mawr and Pont Aberglâs. llyn, near Beddgelert.

\section{$\Longrightarrow$ \\ CLASS. V. \\ PENTRANDRIA.-MONUCYNIA.}

Lithospermum purpuro-coerdenum. Creeping Gromwell.-Smith, 214.-Eng. Bot. 1 17--P. May.

On the top of a buthy hill on the north-fide of the town of Denbigh. Ray.

AnChusa SEMPERvirens. Evergreen Alkant.-Smith, 2 I 5 . Eng. Bot. 45--P. May-July.

Among the ruins of Bafingwerk or Maes Glas abbey, Holywell. This plant appears to have been mittaken by Mr. Waring, in With. 228, for Pulmonaria anguff:folia. Dr. Smith is of opinion that a leaf of it fent to him was that of Symphytum tuberofum.

Pulmonaria maritima. Sea Lungruort.--Smith, 218.Eng. Bot. 368. - P'. July. 
Among the fand on the fea.coaft at Orme's Head; - near Trefarthen, in Anglefea, about half-way betwixt the ferry from Caernarvon and Moel y Don;-by the river Llyfni, that runs from Llyniau Nantlle into the fea, about half-way betwixt Llandwrog and Clynog, in Caernarvonthire.

Sympéptum orficinale. Common Comfrey.-Smith, 218. Eng. Bot. $817 .-$ P. Miy, June.

On the banks of the Alyn, betwixt Wrexham and Chefter, and about half a mile eaft of the road.

Borago officinalis. Common Borage.-Smith, 219.Eng. Bot. 36. P. June, July.

Amongft the rubbin at Diganwy caftle; and on the fum. mit of the rock at Llandudno, both near Conwy;amongt the rubbith on Harlech marth, juft below the caftle.

Hottonia falustris. Featherfoil.-Smith, 226.-Eng. Bot. 364-P. June, July.

In the diches by the road-fide betwixt Pool quay, and the turupike leading to Welh Pool.

Lysimachia vulgaris. Fellow Loofefrife--Sinith, 227 . - Eng. Bot. $761 .-P$. July.

About the fides of pondis in Caernarvonthire and Anglefea, not very uncommon.

Lysimachia tiyrsifiora. Tufted Loofefrife.-Smith, 228. - Eng. Bot. 136.-P. June, July.

This plant is faid to have been found at Llyn Llechylched, but the reverend $H$. Davies informs me that he has fought for it there in vain.

Anagallis tener.la. Bog Pimperiel.-Smith, 230.Eng. Bot. 530.-P. July, Auguft.

In fwampy meadows near Caernarvon, not uncommon. 
Contolvulus solpanellas Sea Bindweed.-Smith, 233. Engiifh Bot. 31/4-P. July.

Among the fand on the fea coaft near Orme's Head;--and on the fouth-weft of Caernarvonfhire and Anglefea.

Campanula kotundizolia. Round leaved Bell fower.Smith, 235.-P. July-September.

A fingle-flowered variety of this plant is very common on the higher parts of all the mountains about Llanberis and Snowdon.

Campanula latrfolia. Giant Bell-fower.-Smith, 236. Eng. Bot. 302 -P. Auguft.

Hedges near Holywell.

Cámpanula trachelium. Nettle-leaved Bell-flower.Smith, 238.-Eng. Bot. 12.-P. July.

Among the buthes near Bafingwerk abbey; - and in the hedges of a wood near the road leading from St. Afaph, to Denbigh.

Campanula glomerata. Clufered Bell flower.-Smith, 239.-Eng. Bot. 90. - P. July, Augun.

In the calcareous paftures near Rhyd y Cilgw'yn, betwixt Denbigh and Ruthin, about two miles from Ruthin.

Campanula hederacea. Ivy-leaved Bell-forver, Smith, 239.-En;. Bot. 73.-P. June-Aug.

In fwampy places in the meadows of the vale of Llanberis, about $\frac{x}{4}$ of a mile beyond the village; - by the road fides near Llanrwft;-and near the cataract, Rhaiadr y We. nol, five miles from Llanrwit.

Lobelia nortmanna. - Water Lobelia.-Smith, 242. Eng. Bot. 1 40.-P. July, Auguit.

Plentifully in the river Seiont, betwixt tha lower pool of Llanberis and Cwm y Clo;-In Llyn y Cwn;-L!yn Idwel; and Ffynnon Frech, all near Liauberis. 
Impatiens noli me tangere. Yellow Balfam.-Smith 243.-A. Auguit.

On the banks of the river Camlet at Marrington, in the parih of Chirbury, about five miles from Montgomery.

Viol $\Lambda$ Palustris. Marß violet.-Smith, 246.-Eng. Bot. 44\%-P. April, May.

Moffy bogs near Llyn Aled, in Denbighthire.

Viola lutes. Yellow violet.-Smith 248.-Eng. Bot. 721.-V. Grandiflera.-Hudf. 380.-P. May-September.

By the road fide leading from Llanrwit to Ffettiniog, near the bridge about a mile from Penmachno;-and on the . road from Machynlleth to Llanydloes, from the tenth mile.ftone nearly all the way to Llanydloes.

Verbascum iychnitis. White Mullein.-Smith, 250. Eng. Bot. 58.-B. July, A uguft.

Betwixt Gresford and little Acton in Denbighthire, about $\frac{x}{4}$ of a mile from the latter place, abundantly.

Atropa belinadonna. Deadly Nightfrade-Smith, 255. Eng. Bot. 592.-P. June, July.

In rough places about Valle Crucis abbey, near Llangol. le11; and by the road fide, betwixt Hawarden and Chefter.

Samolus valerandi. Brookzeed.-Smith, 259.-Eng. Bot. 703-P. June, July.

In the marth near Caernarvon caftle.

Rinamus catharticus. Buckthorn.-.Smith, 261.-S. May, June.

Garreg wen rocks, near Garn, Denbighnire. 
Euonimus europizus. Spindle tree,-Smith 262.-Eng. Bot. 362. S. May.

In the copfe by Euloe cafte, near Hawarden, Flinthire,

Ribes Grossularia. Rough Goofeberry.-Smith, 286. S. April.

Rough places about Denbigh cafte.

Ribes uva-Crispa. Smooth Goofeberry.-Smith, 266.-S. April.

A bout Denbigh cafle, along with $R$. Grofuluria-and in the hedges by the road fide leading from Caernarvon to Bangor.

Glaux maritima. Black Salt-wort.-Smith, 268.-Eng. Bot. I3.-1. June, July.

S.lt marhes near Conwy;-Dulas bay;-betwixt Amlwch and Beaumaris, Anglefea ; - and in other marfhy ground on the lea coafts.

Vinca minor. Leffer Perizuinkle.-Smith, 270.-P. May.

In the hedges by the road fides near Pig y Frân, in the parifh of St. Afaph.

\section{PENTANDRIA.-DIGYNIA.}

Chenopodium maritrmum. Sea Goofe-foot.-Smith, $2 ; 8$. Eng. Bot. 633. A. July, Auguft.

On the fea-coaft near Llanfaglan church, about two miles fouth-welt of Caernarvon.

Beta maritima. Sea Beet.-Smith, 279.-Eng. Bot. 285.-P. Augutt, September.

In muxddy places on the fouth weft coaft of Anglefea.

Salsola Kal. Prickly Salt-wort. - Smith 280.-Engo Bot. 634-A. July.

A mongtt the fand on the coaft of Anglefea, betwi tt the ferry from Caernarvon and Mocl y don. 
Gentiana Pneumonanthe. Marß Gentian.-Smith, 285 .

Eng. Bot. 20.-P. Auguft, September.

In moift and uncultivated grounds in Anglefea, but not common.

Gentiana amarella, Autumnal Gentian.-Smith, 287. Eng. Bot. $236 .-A$. Augult.

In calcareous ground betwixt Holywell 'and Rhyddlan: fides of banks near Denbigh.

Gentiana campestris. Field Gentian.-Smith, 288. Eng. Bot. 237.-A. Auguft, September.

By the road fide leading from Holywell to Rhyddlan, about three miles from Holywell, along with the laft fpecies :-near Llanberis.

\section{Umbellate Plants.}

Eryngium Maritimum. Sea Eryrgo.-Smith, 288.Eng. Bot. 718-P. July, Auguft.

Among the fand on the fea-coaft near Gogarth, under the Llandudio rocks;-and near Harlech in MerionethShire.

Hrdrocotyle inundatum, Floating White-rot.-Smith, 390.-Sifon inundatum. Eng. Bot. 227.-With. 301.B? IVay, June.

In rivulets in Anglefea, very common.

Crithmum Maritimum. Rock Samphire. $\neg$ Smith, 306. Eng. Bot. $819 .-$ P. Auguft.

Rocks above the fea near Llandudno, Caernarronhire;betwixt Clynog and Nevin;-and on the coaft of Anglefea.

Mi um athamanta. Common spignel or Men.-Smith, 308-Ethufa meum. With. 303.-P. May.

In mountainous pafiures near Dolgelle. 
Sium angustifolium. Narronu-leaved water parfinep.Smith, 313.-Eng. Bot. 139.-P. July, Auguit.

In rivulets in Anglefea, not uncommon.

CEnanthr pimpinelloides. Parfley Water-Drapruort.Smith, 318.-Eng. Bot. 347-P. July.

In the falt marfh near Aber, Caernarvonfhire.

OEnanthe crocata. Henlock Water-Dropwort. - Smith, 3rg.-P July.

In watery places, in the neighbourhood of Garn, near Denbigh, too conmon.

Scandix odorata. Sweet Gicely. - Smith, 323.-Eng. Bot. 697 .

Among the trees in the ruins of Valle Crucis abbey, near Llangollen.

Sayrnium olusatrun. Alexanders-Smith, 328.-Eng. Bot. 23u. - B. May.

On Prieftholme ifland near Beaumaris, in plenty.

Anethum foeniculum. Common Fennel -Smith, $33^{\circ}$. B. July, Auguft.

Near the rnins of Diganwy cafte, and on the Great Orme's Head. - In Rhyddlan church-yard.

Apium Graveolens, Will Celery-Smith, $333-B$. Auguit. .

Sides of ditches in Anglefea.

PENTANDRIA.-TRIGYNA.

Sambucus Eivlus. Druarf Elder, - Smith, 336-Eing. Bot. 475 - P. July.

In a hedge on the coatt of Anglefea, near the Moel y Don ferry houfe:-near Llanfaelog, five miles north weft of - Aberffraw, Anglefea :-In a liedge near Harlcch cafte. 


\section{PENTANDRIA. - TETRAGYNIA.}

Parnassia palustris. Grafs of Parmafus.-Smith, 340. Eng. Bot. 82.-P. Aug. - October.

In moit places among the rocks about $\mathrm{Tull} \mathrm{D} \hat{\mathrm{u}}$, above Llyn Idwel.

\section{PENTANDRIA. - PENTAGYNIA.}

Statice Armeria. Thrift.-Smith, 340.-Eng. Bot. 226. $-P$. June - Auguft.

In the Salt-marh near Caernarvon caftle; - fea coaft at Dulas bay, Anglefea.-On the rocks near 'Tull $\mathrm{Du}$, and thofe of Snowdon.

Statice Limonium. Sea Lavender.-Smith, 341-Eng. Bot. I02.-P. July, Auguft.

In the Salt-marh at Dulas bay, Angleíea.

Linom usitatissimum. Common Flax.-Smith, 242.A. July, Auguft.

About a mile and a half from Montgomery, on the right of the road leading from thence to Newtown.

\section{PENTANDRIA. - HEXAGYNIA.}

Drosera rotundifolia. Round-leaved Stun-dew.-Smith, 346. -July, Augurt.

In almoft all the bogs on the moors and mountains of Caernarvonfhire.

Drosera longifolia. Long-leaved Szun-deru.-Smith, 347 , Eng. Bot. 868.-P. July, A uguft.

In peaty bogs near Bedugelert, Caernarvonfhise. 


\section{CLASS. VI.}

\section{HEXANDRIA. - MONOGYNIA.}

Ornithogalum umbellatum. Common Star of Betblebem.-Smith, 364.-Eng. Bot. 130.-P. April - May.

In a wood at Mats y Porth, near Newborough, An. glefea.

Scilla verna. Vernal Squill.-Smith, 364.-Eng. Bot. 23.-P. April-June.

Meadows about Gloddaeth, near Conwy;-and on the fand banks by the Llanddwyn rocks, in Anglefea.

Anthericum serotinum. Mountain Spider-zort. Smith, 367.--Eng. Bot. 793.-P. June.

On the ledges of the high rock called Clogwyn du'r Arddu, betwixt Llanberis and Snowdon;-and on the inaccersable rocks near 'Tuil $\mathrm{D} \hat{u}$, above Llyn Idwel, in abuídance.

Narthecium ossifragum. LancafBire Afphodel. - Smith, 368.-P. July-Auguft.

In all the peat bogs betwixt Cacrnarvon and Llanberis.

Asparagus officinalis. - Common Afparagus. - Smith, 369. - Eng. Bot. 339. - P Auguft.

Sandy banks by the fea fide betwixt Llangwyen and Llan. faelog, near Aberffraw, Anglefea; -and near the pool at Llanfaclog.

Convalinia majalis. Lily of the Valley._Sinith, 390. P. May.

In thady places on the north-weft fide of Garreg-wen rocks, near Garn, Denbigh?hire. 
Juncus Acutus. Great ßarp Sea-rif/3.-Smith, 374.-P. July.

On the fandy coaft near Harlech, and in various other parts of the coaft of Merionethishire, plentifully.

Juncus triglumis. Three-flozvered Ru/b.-Smith, 382.P. July.

In the afcent from Llanberis to Glyder, but only in one fmall fpot that lies between a fmall eminence called Bryn Brás, and a rivulet called Avon Lâs.

\section{HEXANDRIA.-TRIGYNIA.}

Rumex maritimus. Golden Dock.-Smith, 393.-Eng. Bot. 725.-P. July, Auguit.

On Rhyd marfh, near Preltatyn, Flinthire, in abundance.

Rumex digynus. Mountain Sortel.-Smith, 395.-P. June, July.

In the cleft of 'Tull Dû, above Llyn Idwel; - and on the higher rocks of Clogwyn y Garnedd.

Triglochin Maritrieum. Sea Arrozu.grafs.-Smith, 399.-Eng. Bot. 255.-P. May-Auguft.

In the falt-marfh near Cacrnarvon caftle.

\section{HEXANDRIA.-POLIGY. IA.}

Alisma Natans. Flgating Water Plantain. -Smith, 402. -Eng. Bot. 375.-P. July, Augut.

In the lake below Dolbadarn cafle; and in the rivulet that runs part the cafle into the lake:-in the fouth end of Bala lake, Nieriunethinire.

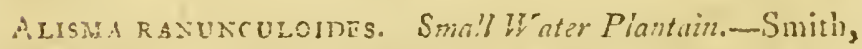
402.- Evg. Bor. 326.-P. July, Augutt.

Ir. Riyd marft, nea: Preftat ýn, Fintfite. 


\section{CLASS VIII.}

\section{OC'TANDRIA-MONOGINIA.}

Epilobium angustifolium. Rofe-bay, Willequ-berb. Smith, 409.-P. June-Aligun.

Among the bufhes in feveral of the meadows in $\mathrm{C}_{w \mathrm{~m}} \mathrm{y}$

$\mathrm{Clo}$, at the bottom of the lower Llanberis lake.

Chlora perfoliata. Yellozu Centaury.-Smith; 413.Eng. Bot. 60.-A. June-September.

On the fide of the hill by the road-fide leading from Wenefred's well at Holywell, to the fea-coaft.

VAcciniUm MYRTILlus. Bilberry.-Smith, 4I.4.-Eng. Bot. 456.-S. May.

In plenty on nearly all the Welh moors and mountains.

Vaccinium uliginosum. Great Bilberry.-Smith, 415.Eng. Bot. 58 1.-S. April, May.

In the moit high woods about Gwydir, near Llanrwit.

Vaccinium vitis idea. Corv-berry.-Smith, 4 I 5 - Eng. Bot. 598.-S. May, June.

On the mountains of Caernarvonhire; and on Cader Idris, in Merioncthhire.

Vaccinium oxycoccus. Cranbiry.-Sinith, 416.-Eng. Bot. 319.-P. May, June.

In the peat-bogs in various parts of the mountains of $\mathrm{Cacr}$ narvonthire.

Ertca tetralix. Crofs-leaved Heath.-Smith, 418.-S. July, Auguit.

On all the moors, in abundance. - Near Dulas bay, in Anglefea, I found a very beautiful white variety of this plant. 
Erica cineren. Fine-leaved Heath.-Smith, 418.-S. July, Auguft.

On all the moors.

Daphne laureola. Spurge Laurel.-Smith, 421.-Eng。 Bot. I I9.-S. March.

Woods and hedges. In Park Pierce; and in the Creit, near Denbigh.

\section{OCTANDRIA. - TRIGYNIA.}

Pot.ygonum bistonta. Great Snakequeed.-Smith, $42 \%$ -Eng. Bot. 509.-P. June.

In the moitt meadow in front of Plâs $\mathrm{On}$, in the parin of Mold.

Polygonum viviparum. Alpine Biflort.-Smith, 428.Eng. Bot. 669.-P. June, July.

On Crib Coch, above Ffynnon Frech, near Llanberis.

Polygonum fagopyrum. Buck-wheat. - Smith, 430.A. July, Auguit.

By the fide of the road that leads from Ruthin to Llangollen, though probably from feed fcattered in its way from fome adjacent fields in which this plant was culti. vated.

\section{OCTANDRIA. - TETRAGYNIA.}

Paris euadrifolia. Herb Paris.-Smith, 43 I.-Eng. Bot. 7.-P. May.

Among the thickets on the north fide of Garreg Wer rocks, and on the oppofite fide of the rivulet.

Adoxa moschatelolina. Tuberous Mofchatell.-Smith, 432.-Eng. Bot. 453.-P. April, May. 
In the hedges about Garn, near Denbigh, common;-and under large fragments of the rocks above Llyn Idwel, half a mile above the pool, in great luxuriance.

C.LASS IX.

\section{ENNEANDRIA.-HEXAGYNIA.}

Butomus umbellatus. Floqvering $R u \mu_{0} .-S m i t h, 435$. -Eng. Bot. 65 1.-P. June, July.

In feveral of the rivulets in the illand of Anglefea.

\section{$=$ \\ CI, ASS \. \\ DECANDRIA. -MONOGYNIA.}

Andromeda polifolia. Mar/h Andromeda.-Smith, 44 I. -Eng. Bot. 713.-S. June.

In a moraffy flat, about a mile north-eaft of Llyn Aled, called Gors y Caffeg, or Mare's Bog;-and in another place about the fame diftance weft of the pool.

\section{DECANDRIA.-DIGYNIA.}

Chrysosplenium oppositifolium. Oppofite-leaved Golder Saxifrage.-Smith, 448.-Eng. Bot. 490.-P. May.

About the fides of rivulets among the higher mountains very common.

Chrysosplenium alternifolium, Aliernate-leaved Golden Saxifrage.-Smith, 447.-Eng. Bot. 54. P. May.

In moilt places in the upper wood at Tower, near Mold.

Saxifraga steliaris. Hairy Saxifrage:-Smith, 4q8.Eng. Bot. 167.-P. June, July. 
Among the rocks near the foot of the waterfall at Aber, in Caernarvonfhire; -and in fimilar fituations about the waterfall', Caunant Mawr, near Dolbadarn caftle.-In almoft all the wet alpine fituations in Caernarvonhire. -On Cader Idris, in Merionethfhire.

Saxifraga nivalis. Cluftered Alpine Saxifrage.-Smith, 449.-Eng. Bot. 440.-P. May-September.

On the rocks about Tull Dû, above Llyn Idwel, and particularly about the upper parts of the chalm;near the fummit of Glyder Vawr; - on the higher parts of Clogwyn y Garnedd; and on Clogwyn du'r Arddu.

Saxirraga oppositifolia. Purple Saxifrage.-Smith, 45 c. -Eng. Bot. 9.-P. April, May.

Among the rocks about Tull Dû and Glyder;-on Clog. wyn y Garnedd;-Clogwyn du'r Arda ; - and Craig y Cae, Cader Idris.

Saxifraga granulata. White Saxifrage.-Smith, $453 .-$ Eng. Bot. 500.-P. May.

In dry places in Garn Dingle, by the rivulet at the bottom of the glade.

Saxifraga thinactruites. Rue-leaved Saxifrage.-Smith, 454.-Eng. Bot. 501.-A. May.

On the walls of the church-yard of Conwy.

Saxipraga cissitosa. Tufted Alpine Saxifrage.-Smith, 455.-Eng. Bot. 794.-P. June.

Very fparingly on the rocks above Cwm Idwely

Saxifraga Palmata. Paimate Saxifrage.-Smith, 456.Eng. Bot. 455.-S. pelrea. With. 890.-P. May, June.

On the rocks near the foot of Tull Dú, above Llyn Idwel. 


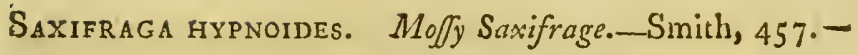
Eng. Bot. 454--P. May, June.

On alpine rocks in Caernarvonfhire, fufficiently common.

Sceleranthus perennis. Perennial Knavuel. - Smith, 458. - Eng. Bot. 352.-P. Aug. Sept.

In fandy places by the road-fide, betwixt Corwen and Bala, that paffes through Llandrillo.

Saponaria officinalis. Soaprwort - Smith, 459.-P. Augunt, September:

A mongft the ruins and rubbith of Bafingwerk abbey, near Holywill; - and in the hedges of the lane that leads from Llanrhaiadr to the cataract of Piftyll Rhaiadr, in Montgomery hire.

\section{DECANDRIA.-TRIGYNIA.}

Cucubalú baccifer. Berry bearing Cbicktuedo -..Smith, 464. - C. bacciferus. With. 4II.-P. June, July.

This plant was found in a hedge near Llanidan, in Anglefea, in the fummer of $179^{\circ}$, by the reverend Evan Lloyd, of Amlwch; but he afterwards fought for it in the fame place in vain.

Silene anglica. Englifb Catcbfy. - Smith, 46,- A. July,

In a corn-field near the coaft, not far from Llanfaglan church, three miles from Caernarvon.

Silene nutans. Nottingbam Catcbfy..-Smith, 466.Eng. Bot. 465.-P. June, July.

Among the ruins of Diganwy cafle; and near Gloddaeth, Caernarvonhire.-On the rocks above the mine works at Dalea Gûch, Flinthire.

FOL. II.

C C

SIIENE 
Silene Maritima. Sia Catclify.-Smith, 468.-P. June -September.

Anong the peibles on the coaft by the Great Orme's Hcad; - on the fea-coaft near Llanfaglan cliurch; near the Llanddwyn rocks, Anglefea; - along the fide of Llyn Cwcllyn, betwixt Caernarvon and Beddgelert; in plenty; - and among the high rocks of Clogiryu du't Arddu, betwixt Llanberis and Snowdon.

Silene acaulis. Mojs Campion.-Smith, 472.-P. May, June.

On the higheft rocks of Caernarvonfhire, not uncommots.

Sieliaria nemorum. Wood Stithruort.-Smith, 473.- Eng. Bot. 92.-P. May, June.

In a hedge clofe to the river, about 100 yards above the ford at Rhyd y Ddae Dwfr, betwixt St. Afaph and Rhyddlan, and on the Rhyddlan ficte of the river.

Strllaria uliginosa. Bog Stitclyuort.-Smith, 476.-A. June.

In a picce of moilt ground about a mile from Llanrwf. and within three or four yards of the turnpike roas leading from thence to Conwy.

Arenaria peplones. Sea Sandwort. - Smith, 4776 Eng. Bot. $189 .-$ P. June, July.

Among the fand on the fea-coaft near the Great'Orme's Head; Cacrnarvonfhire; - and near the Llanddwrn rocki, Anglefea.

ARENARia Marina. Sea Spurrey.-Smith, 480:-A. June - Auguft.

In the falt-murh near Caernarvon cattle; - and near Dulas lay, Anglefea.

ARENARIA 
Arenaria tenuifolia. Fine-leaved Sanácuort,-Smith, 481. - Eng. Bot. 219.-A. June.

Among the fand on an ifland in Llanddwyn, Anglefea.

Arenaria verna. Virnal Sandwort.-Smith, 481.-Eng. Bot. 5 I2.-P. May-Auguft.

Near the fide of the road leading from Holywell to St. Afaph, common;-and in various mountainotis fituations about Llanberis and Snowdon.

Variety $\beta$. Smith, $482 .-A$. juniperina. With. 424 .

Amongt the rocks near Tull Dû, above Llyn Idwel; and on Clogwyn y Garnedd.

Variety $\gamma$. Smith, 4\$2.-A. laricifolia. With. 424 .

Near Tull Dû, growing along with the laft variety.

\section{DECANDRIA.-FENTAGTNIA.}

Cotrledon umbilicus. Navelwort._Smith, 484.-Eng, Bot. 325.-P. June-Auguft.

On old walls and moift rocks in Caernarvonhire and Merionethhire, very common.

SeduM Telephrum. Orpine.-Smith, 485.-P. Auguif.

In hedges near the coaft about Caernarvon;-and among the buhes of the rock called Tuthill, behind the hotel at Caernarvon.

Sedum anglicum. Englifs Stonecrop.-Smith, 486.--Eng. Bot. I 71.-P. June, July.

On the rocks of Caernarvonthire, every where.

Sedum sexangulare. Infipid Stonecrop.-Smith, 488.-

S. acre 3 . Hudf. ig6. -P. June, July.

In the fand near Rhuddgaer warren, Anglefea, nearly oppofite to tìe town of Caernarvon. 
SEDUM RUPESTRE. Rock Stonccrop.-Smith, 490.-Eng. Bot. I 70.-P. July.

On the north fide of Penmaen Mawr, amongt the lonfe ftones above the turnpike road, vcry near the inacceffible rocks:-amongtt the rocks near ' T'ull $\mathrm{D} \hat{\mathrm{u}}$, called Creigiau Hysfa Bengam; -and on a wall fouth of Gw wy dir chapel, near Llanrwit.

Lyennis viscaria. Red German Catchfjo-Smith, 494. -Eng. Bot. 738. - P. May, June.

On the rocks of Craig Breiddin (or Craig Wreidhir), a mountain about eight miles north-eaft of $\mathrm{W}$ clih Pool.

Cerastium alminum. Alpine Chickrveed.-Smith, 500 . -Eng. Bot. 472.-P. June, July.

A mong the rocks of Clogwyn y Garnedd; and on the nortly fide of $\mathrm{Yr}$ Wyddfa, the funnmit of Snowdun;and on the ledges of Clogwyn du'r Arddu.

Cerastium latifolium. Broad-leaved rough Chickiveed. -Smith, 501.-Eng. Bot. 473.-P. June.

On Clogwyn y Garnedd, growing along with the laft fpecies.

Sprergita nodosa. Knotted Spurrey.-Smith, 403.-Eng. Bot. 694--P. July, Auguft.

In fwampy ground in the neighbourhood of Caernarvon, not uncommon.

Spergula subulata. Ciliated Awl-תaped Spurrej.Smith, 505.-S. laricina. Hudf. 203-P. July, Auguft.

In dry paftures about Deûnant, betwixt Llanfannan anc? Denbigh; - and on the firft common on the afcent of the hill from Nant Glyn, towards Henllan; near Den. bigh. 


\section{CLASS XI. \\ DODECANDRIA.-TRIGYNIA.}

Reseda luteola. Dyer's-zued, or Weld-Smith, 512,

Eng. Bot. 320.-A. July.

On the banks of the coaft of Anglefea, betwixt the ferryhoufe from the town of Cacrnarvon, and that at Moel y Don; - among the ruins of Caftell Doiforwyn, near Newtown.

Euphordia portlandica. Portland Splirge. - Smith, 515.-Eng. Bot. 441.-A. July, Auguit.

Amongt the fand on the coaft near Caernarvon;-near the ruins of Llanddwyn abbey, Anglefea.

Euphoreia amygdaloides. Wood Spurge._Smith, 520. Eng. Bot. 256. - P. April, May.

In the wood Letwixt Trap Bridge and Dol Beledr, in the parifh of Henllan, Denbighthire, clofe to a dangerous path called Llwybr y Gorth Goed.

\section{CLASS XII.}

\section{ICOSANDRIA.-MONOGYNIA.}

Prunus Padus, Bird Cherry.-Smith, 526.-T. May.

In woods and hedges in the neighbourhood of Mold, very cominon.

\section{ICOSANDRIA.-PENTAGYNIA.}

PrRus torminalis. Wild Service Pear-tree._Smith, 532. -Cratag. Eorminalis. Eng. Bot. 298. -With: 458.-F. April, May.

On the weit fide of Garreg Wen rocks, near Garn, Den. bighthire, in abundance. 
Pyrdes aucuparia. Mountain Aßo.-Smith, 533.-Sorbus aucuparia. Eng. Bot. 537.-With. 460.-T. May.

In woods and hedges throughout North Wales, very common.

Prrus hybrida. Bafard Mountain Af.-Dmith, 534. _-Sorbus bybrida. With. 461.-T. May.

On the north wall of Caftell Dinas Erân, near Llangollen.

PYrus ARIA. White Beam-tree-Smith, 534.-Crateg. aria. With. 458 . - T. May.

In the fiffures of rocks of Craig Breiddin, MontgomeryNire; - the north end of the Great Orme's Head;-and of the rocks of Penmaen Mawr, immediately above the turnpike road. This is undoubtedly the fhrub that the Wellh call Prcn Lemwn, or "Lemon tree." In the fummer of 1801 , I examined the very plant on Penmaen Mawr, from which all the cuttings are taken for planting in gardens. It derives this rame from the fancied refemblance of its fruit to an extremely diminutive lemon.

Spirat filipendula. Dropwort.-Smith, 534.-Eng. Bot. 284.-P. June, July.

On the dry and elevated land, in a calcareous foil, of Llan. dudno, near Conwy.

\section{ICOSANDRIA.-POLYGYNIA.}

Roosa spinosissma. 'Bumet Rofe.-Smith, 537-Eng. Bot. $187 .-\mathrm{S}$. July.

In dry places about the foot of Penmaen Mawr;-near Llandudno; - in the hedges betwixt Bangor and Caernarvon, and in various other places.

Rosa villosa. Apple Rofo--Smith, 538. - Eng. Bot. 583 : S. June.

In the hedges of the road from Llanydloes to Newtown. 
Rosa tormentosa. Downiy leaved Dog.rofe-Smith, 539. R. villof, var. 2. - With. 466. -S. June-July.

Found in the fame fituations as the laft fpecies.

RuBus inzus. Rapperry.-Smith, 54I.-S. May-June.

In thickets amongt the mountains betwixt Caernarvon and Llanberis; - and in various other parts of North Wales.

Rubus saxatilis. Stone bramble. - Simith, 544.-P. June-July.

A mongft loofe ftones about the Great Ormes Head;-and near Llyn y Cwn above Llanberis.

Rubus chammiorus. Cloud berry.-Smith, 545.-Eng. Bot. 716.-P. May-June.

In the peat bogs of the mountains of Carnarvonfhire and Merionethhire, not uncommon.

Potentilia rupestris. Sirazuberry-fowered Cinquefoil. Smith, 548.-P. June - July.

On the rocks of Craig Breiddin, Montgomeryfhire.

Potentilla argentea. Hoary Cinquefoil.-Smith, 549. Eng. Bot. 89.-P. June-Auguft.

At the foot of one of the towers of Montgomery caftle.

Potentilla verna. Sprizg Cinquefoil._-Smith, $55^{\circ}$ Eng. Bot. 37--P. April-May.

Dry places ahout Gloddaeth near Conwy.

Tormentili $\Lambda$ reptans. Trailing Tormentil._._. Smith 553.-Eng. Bot. 864.-P. June-July.

On banks and about hedges in a fandy and barren foil, fufficiently common. 
Geum rivale. Water Avens.-Smith, 554-Eng. Bot. 106. -P. June-July.

A mong the rocks of the waterfall called $R$ haiadr Mawr, betwixt Conwy and Llanrwit; - and alfo on the rocks very near the fummit of Snowdon.

Comarum palustre. Marßh Cinquefoil. -Smith, 556 . Eng. Bot. 172.-P. June-July.

In ditches near the river Seiont not far from the bottom of the Llanberis pools; - and in muddy and putrid marhes in various parts of Anglefea.

\section{CLASS XIII.}

POLYANDRIA.-MONOGYNIA.

Glaucium luteum. Yellow horned Poppy.-Smith, 563:

Chelid. glaucium. - Eng. Bot. 8. -With. $584 .-\Lambda$. July Augufț.

On the fea coaft about the Great Ormes Head ; - and betwixt Caernarvon and Llanfaglan church.

Papaver cambricum.-Yellow Poppy.-Smith, 568. - Eng. Bot. 66. - P. June-July.

Near a wall by the road leading to Llanrwit, a little beyond the village of Llanberis; - an Craig Breiddin, in Montgomeryfhire;

Nymphea lutea. Yellow Water lily -Smith, 569.- Eng. Bot. I59-P. July-Auguft.

In rivers and ftagnant waters, not uncommon.

Nrmphea alba. White Water-lily.-Smith, 570.-Eng. Bot. 160.-P. July.

In the river Seiont near $\mathrm{Cwm}$ y Clo, at the bottom of the Ilanberis pools; - In Llỵn Tecwyyn Ifa, a pool near the road 
road betwixt Tanybwlch and Harlech;-and in Llyn Mwyngil, betwixt Dolgelle and Machynlleth.

Cistus marifolius. Houry dwarf Ciftus.-Smith, 572. Eng. Bot. 396-C. anglicus. With. 490.-C. birfutus, Hudf. 232.-S. May, June.

On the hill of Diferth caftle near Rhyddlan, Flinthire, plentifully ; - Gloddaeth ; - Llandudno;-and on the weft fide of Burdd Arthur, near Llandonna, about five miles from Beaumaris, Anglefea.

Cistus guttatus. Spotted-flowered Ciffus.-Smith, 573 . Eng. Bot. 544.-A. June, July.

Sandy pafture ground on the mountain near Holyhead, called Llech Ddu.

Cistús her.ianthemum. Druarf Ciftus. -Smith, 575 . S. June-Augurt.

On Diferth cafte hill;-Calcareous paftures about Llandudno, near Conwy; - and on Llanymynech hill in Montgomeryhire.

\section{POLYANDRIA.-PENTAGYNIA.}

A euilegia vulgaris. Common Columbine.-Smith, 578 . Eng. Bot. 297.-P. July.

Thickets near Bangor, Caernarvonfhire.

\section{POLYANDRIA.-POLYGYNIA:}

Thalictrum alpinum. Alpine Meadowerue.-Smith, 584.-Eng. Bot. 262.-P. June.

On the rocks about Llyn y Cwn, above Llanberis, and Tull Dû; -and on Clogwyn y Garnedd,

Tinalictrum Minus. Lefer Meadorv-rue,-Smith, 584. Eng. Bot, 1t.-P. June-Auguft. 
On Diferth cafle hill; -nea. Diganwy caftle; - among the rocks about Tull $D$ ú, and Snowdon;-and on Cader Idris, near Dolgelle.

Ranunculus linguA. Great Sfearwort.--Smith, 588. Eng. Bot. I00.-P. July.

In wet paftures about Caernarvon, common.

Ranunculus Granineus. G affy Cronvfoot.-Smith, 588 . P. April-June.

This plant grows in very dry meadows, - and is faid to have been found in the ncighbourhood of Llanrwit; late botanifts have however fought for it in vain.

Ranunculus parviflorus. Small forwered Crowfort.Smith, 594.-Eng. Bot. 120.-A. May, June.

In a gravelly foil near Holyhead, not uncommon.

Trolzius Eurofeus. Globe Florver.-Smith, 597--Eng. Bot. 28.- P. May, June.

In the hollow immediately below the cataract of Caunant Mawr near Dolbadarn caftle; -in the vale of Llanberis; and in the meadows near Llyn Cowlid,-a lake in the mountains above and nearly north of Capel Curig.

Helleborus viridis. Green Hellebore.-Smith, 598.Eng. Bot. 200.-P. April.

In the wood at Plâs Newydd, near Denbight, the feat of Robert Watkin Wynne, efq.

Hellenorus foetidus. Stinking Hellebore.-Smith, 598 . Eng. Bot. 6r3-P. March, April.

In Park Pierce, and the Creft near Denbigh. 


\section{CLASS XIV.}

\section{DIDYNAMIA.-GYMNOSPERMIA.}

Ajuga alpina. Alpine Bugle--Smith, 604.-Eng. Bot. 477--P. June, July.

Near the fummit of Carnedd Llewelyn, in Caernarvon. Thire.

Teucriom chamerorys. Wall Germander.-Smith, 60\%. -Eng. Bot. 680.-P. July.

In the north-weft hedge of the bowling-green on Ruthin caftle; where it has grown for many years.

Nepeta cataria. Cat.mint.-Smith, 608.-Eng. Bot. I37.-P. July.

In the hedges of the road leading from Bangor to Caernarvon.

VERBENA OFFICINALIs. Common Vervaint.-Smith, 608. -Eng. Bot. 767.-P. July, A uguft.

In wafte places near Caernarvon caftle, in abundance.

Mentha odorata. Bergamot Mint.-Smith, 615.-P. July, Augurt.

This uncommon fpecies is found in a fmall brook or ditch near Capel Curig in Caernarvonhire.

Mentha gentịlis. Bufloy red Mint.-Smith, 621.-P. Auguft.

In poọs and brooks betwixt Mold and Llanwrit.

Galeopsis vizlosa. Downy Hemp-nettle. - Smith, 629:G. grandiflora. With. 529.-A. July, Augut.

In fandy fielda about Bangor. 
Galeopsis versicolor. Large-forvered Hemp-nettle.Smith, 630.-Eng. Bot. 667.-G. cannabina. With, 529.-G. tetrahit. var. 8. Hudf. 259.-A. July, Augurt.

In cornfields about Chirk in Denbighthire; and in many fmall inclofues by the road fide leadirig from Chirk to Llangollen,

Galeobdolon luteum. Yellonu Dead-netile.-Smith, 631. Eng. Bot. 787.-P. May, June.

In the hedge on the left of the road that leads from Llangollen to Valle Crucis abbey.

Lionurus cardiaca. Motherzuort.-Smith, 637.-Eng. Bot. 286.-P. July, Auguft.

In the hedge on the right of the road leading from Hawarden to Holywell, about two miles and a half from Hawarden.

Origanum tulgare. Common Marjormm.-Smith, 639. P. July, Auguft.

Amongtt the ruins of Conwy cantle; - and in the hedges about Llanrwit.

Thrmes acinos. Bafil Thyme. -Smith, 641. - Eng. Bot. 4rr.-A. July, Auguft.

In a dry field betwixt $\mathrm{Ty}$ Newydd and Eriviatt, in the parifh of Henllan, Denbighthire.

Scuteliaria minor. Lefer Scull-cap.-Smith, 646:Eng. Bot. 524.-P. July, Auguft.

In fwampy meadows and paftures about $\mathrm{C}_{\text {çernarvon and }}$ Llanberis.

\section{DIDYNAMIA - ARGIOSPERMSA.}

Lathrie seuamaria. Greater Tootbrwort.-Smith, Gis4. Eng. Bot. 50.-P. April, MJay. 
In thady places clofe to the rivulet, on the weft fide of Garreg WVen rocks, near Garn.

ÁntirRhinum crmbalaria. Iryy-leaved Srapdragon.Smith, 656.-Eng. Bot. 502.-P. May-Nov.

On an old wall before the door of a gentleman's houfe, called the Hermitage, near Beaumaris, Anglefea ; - and on an old wall, near Mold.

Antirrhinum elatine. Sharp-pointed Fleutllis:-Smith, 658.-A. July - September.

On hedge banks about Ty Newydd, in Rhil, in the parith of Rhyddlan, Flinthire; -in the fir it field from the houfe of Plâs Meifod, on the road leading from Plàs Newydd to Henllan, Ienbigh hire.

Antirrhinum minus. Leaft Snapdragon.-Smith, 660.

A. June-Augurt.

Sandy confields, betwixt the village of Abergeley, in Denbighthire, and the fea.

Antirrhinum majus. Great Snopdragon. - Smith, 66 :. Eng. Bot. 120.-P. July, Aliguft.

On the ruins of Baingwerk abbey near Holywell, FlintMire; - on the iown wath of Caernarvon, near one of the doors of the Englifh clurch;-and on old walls about Ruthin, Denbighinire.

ANTIRRHINUM ORONTIUM. Leffer Snapdragm.-Smith, 66) 2.-A. July, Augunt.

In fandy corn fields, along the fea coat betwixt Abergeley and Conwy ferry.

Schrophularia vernalis. Yellow Figruort-Smith, 564.-Eng. Bot. 567.-B. April, May.

In watry places and hedges. Near Gloddaeth, Caernarronfhire; - and about Llanforda, in Merionethfhire, the feat of Sir Wratkin Williams Wysne, bart. 
Lrmosella acuatica. Mudquort.-Smith, 668,-Eng Bot. 357.-A. July, Auguft.

In Rhyd marfh, near Preftatyn, Flinthire.

Orobanche inajor. Greater Broom-rape.-Smith, 66y. -Eng. Bot. 44r. - P. June, July.

In a fandy foil on the cliffs betwixt Caernarvon cafle and Pont Seiont; - and in fimilar fituations on the coaft of Anglefea, betwixt the ferry-houfe from Caernarvon and Moel y Don ferry.

Orobanche minor: Leffer Broom-rape.-Smith, 670.Eng. Bot. 422.-A. June-Auguft.

A mong the ruins of Diganwy cafte, near Conwy; - and in two or three places among thofe of Conwy caftle.

\section{CLASS XV.}

TETRADYNAMIA.-SILICULOSA.

Subuiaria a euatica.-Awl-wort.-Smith, 676.-Eng: Bot. 732.-A. July.

In an alpine pnol, not far from the village of Llanberis, called Ffynnon Frech, plentifully; -and in Llyn $\mathrm{y}$ Cwh.

DRABA INCANA. Tauifed-psided Whitlow-grafs. - Smith, 673.- - Ling. Bor. 388.-B. May, June.

On the high rocks eat of Tull Du, above Llyn Idwel; called Creigiau Hysfa Bengam.

Lepidium latieolium. Broad-leaved Pepper-zuort.Snith, 682.- Eng. Bot. I 82.-P. July.

On hedge banks near the ftone houfe, betwixt the village of Rhyddlan and the iea; - on a fmall common in Den. bigh caftle, above the high gate.

ThLASPI 
Tinlaspi campestre. Cow-crefs.-Smith, 684.-A.June, July.

In dry lancs neăr Caernarvon, not uncommon.

Thlaspi alpestre. Alpine Shéphard's-purfe.-Smith, $686 .-$ Eng. Bot. 81 --P. June, July.

By the fide of a rioulet in a dingle called Nant Bwlch gr Hiarn, about a mile from Llanrwit bridge, and not more than twenty yards from the turnpike-road leading to Conwy.

Cochlearia officinai.is. Common Scurvy-grafs. - Smith, 688.-Eng. Bot. 55 1.-A. May.

On the fea-coaft, near the Great Orme's Head;-and near Barmouth : - on the rocks of Clogwyn y Garnedd.

Var. \%. Smith, 688.-C. groenlandica. With. 573.

This variety is found in great plenty among the moift rock of all the high mountains of Llanberis and Snowdon.

Cochlearia angrica. Englifh Scurvy-grafs. - Smith, 688.-Eng. Bot. 552.-A. May.

Sea fhores, in a muddy foil, on the north-eaft coalt of Anglefea.

Cochlearia Danica. Danifh Scurvy-grafs.-Smith, 689. -Eng. Bot. 696.-A. May, June.

On a wall on the fide of the hill betwixt Caernarvon and Pont Seiont ; - on the fea-coaft near Llanbadric church, the extreme north point of Anglefea.

Igeris vudicaulis. Naked-falked Candy-tuft.-Smith, 6g2.-Eng. Bot. 327.-A. May, June.

On the fide of the hill, by the road leading from Corwen to Llangollen, about half a mile from Corwen; - on the banks of the road about midway betwixt Cerrig $y$ Druidion and Denbigh.

BUNIAS 
Bunias calire. Sea Rocket.-Smith, 694-Eng. Bot: 23 I.-A. June-September.

On the coaft of Anglefea, near Abermenai ferry.

Crambe marttima. Sea Kale.-Smith, 695--P. May, June.

On the fandy fea-coaft betwixt Rhurdgaer and Llandd wyr, Anglefea :-on the coaft in various parts of the promon. tory of Llỳn, Caernarvonhire.

\section{TETRADYNAMIA.-SILIVUOSA.}

Sisymbrium tenulfolium. Wall Rockit.-Smith, 703. - Eng. Bot. 525.-Brafica muralis. With. 522.- Hudf. 290.-P. June-OEtober.

On the walls of Harlech cafle, $\vec{M}$ erionethinire.

Sismubrium Monense. Dwaif Sea Rocket.-Smith, ;04. -Brafica monengis. With. 593.-P. June, July.

In the fand of the fea-coaft near the Great Orme's Hcad; and near the Abermenai ferry, Anglefea.

Erysimum cheiranthoides. Treacle Hedge-mufard.Smith, 708.-A. July.

- In turnip and cornfields near Tan y Llan, in the parin of Llanyfydd, about five miles north-weft of Denbigh.

Cheirantius sinuatus. Sea Stokk. -Smith, 7 10.-Eng. Bot. 462.-B. July, Auguft.

Newborough fands, Anglefea;-and on the fea-coaft neat Penmorfa, Caernarvonfhire.

Arabis Hispida. Alpine Rock-crefs.-Smith, 713.-Car: damine peiraca. With. 577.-Hudf. 293.-Cardamine baflulata. Eng. Bot. 469.-P. June, July.

On the high rock betwixt Llanberis and Snowdon, called Clogwyn du'r Arddu, plentifully. 
Arabis thaliana, Common Wall-crefs.-Smith, 712.A. April, May.

In the neighbourhood of Henllan, Denbighrhire, in abundance.

TURRITIS HIRsUTA. Hairy Tovver-muffard.-Smith, j16. -Eng. Bot. 587.-P. May, June.

On Garreg Wen rocks near Garn, Denbighnhire.

Brassica oleracen. Sea Cabbage.-Smith, 720.-Eng. Bot. 637-B. May, June.

On the perpendicular rocks at the extremity of the Great Ormes Head; near Aberdaron, in the promontory of Llyn ; - and near Harlech caftle, Merionethfhire.

\section{CLASS XVI. \\ MONADELPHIA.-PENTANDRIA.}

Erodium maritimu:r. Sea Stork's-bill.-.Smith, 728. -Eng. Bot. 6.46.-Ger. maritimum. With. 606. - Hudf., 301.-P. May-Septemuer.

On the fea-coaft near the Great Orme's Head; - -on walls betwixt the town of Bangor, and the Penrhyn Arms; - betwixt Caernarvon, and Harry Parry's bridge, on the road leading to Llanberis; -and on walls on the fea-coaft near Llanfaglan church, Caernarvonfhire.

Geranium phzum. Dufky Crane's-bill.-Smith, 729.Eng. Bot. 322.-P. May, June.

In the wood_above Mr. Pennant's garden at Downing, near Holywell, Flinthire.

Geranium lucidum. Shining Crane'sebill.-Smith, 733. -Eng. Bot. 75--A. Miay, Auguft. 
In Thady places about Gwydir chapel, near Llanrwft;and under the bridge wall at $\mathrm{R}$ ûg, near Corwen.

Geranium rotundifolium. Round-leaved Crane's-bill.Smith, 736.-Eng. Bot. 157.-A. June, July.

In rough places and fterile paftures in the neighbourhood of Garn, near Denbigh.

Geranium columbinum. Long-falked Crane's-bill. Smith, 737.-ing. Bot. 250.-A. June, July.

In corn.fields near the Great Orme's Head; - and near Caennarvon:-in the hedge near the fecond mile ftone, on the road from Caernarvon to Bangor.

Geranium sanguineum. Bloody Crane's.bill. - Smith, 738.-Eng. Bot. 272.-P. July-September.

Near Diferth cafte, Flinthire ; -the Great Orme's Head; - and on the fandy cliffs of the coatt of Anglefea, betwixt the ferry-houfe from Caernarvon, and that at Moel y Don.

\section{MONADELPHIA.-POLYANDRIA.}

Lavatera arborea. Sea Trec-mallozu.-Smith, 742.Eng. Bot. 754.-B. July-October.

On the fea-coalt of Anglefea.

\section{CLASS XVII.}

\section{DIADELPHIA-HEXANDRIA.}

Eumaria claviculata. White Climbing Fumitory.Smith, 752.-Eing. Bot. I03.-A. June, Augult.

Under the walls near a farm-houfe in Gwynant, abour three miles and a half from Beddgelert, at the entrance into Cwm Llan; amongt the ruins of Caergwrle caftle, 
Flint Thire;-unde: Glynn bridge, near Corwen;-in a hedge in the lane at the north end of Bala pool; and in the lane leading from Llanrhaiadr to the cataract of Pifyll Rhaiadr.

\section{DIADELPHIA. - DECANDRIA.}

Genista pilosa. Hairy Green-weed. - Smith, 755.Eng. Bot. 208.-S. May, June.

Betwixt Dolgelle and Llyn Arran, at the foct of Cader Idris, about half a mile from the pool.

Genista anglica. Needle Green-queed.-Smith, 756.Eng. Bot. 132--S. May, June.

In uncultivated ground in Cacrnarvonfhire and Anglefea, frequent.

Orobus tuberosus. Heath Per... Smith, 761.-P. May, June.

In Garn Dingle, near Denbigh, and in the woods of that neighbourhood, very common.

Orobus sylvaticus. Bilter Vetch, -Smith, 762,-Eng. Bot. $518 .-$ P. May, June.

In paftures betwixt the inn at Ffefliniog, and the bridge over the Cynfael, near the waterfalls; - in meadows on the bank of the river Conwy, about feven miles above Llanrwf ; - near the cataract at Dolmelynllyn, fix miles fouth of Dolgelle; and near Cerrig y Druidion, and Y Spytty Evan, in Denbighfhire.

Lathyrus syrvestris. Narrozu-leaved Everlafing Pea. -Smith, 765.-Eng. Bot. 805.-P. July, A uguft.

Woods and hedges near Conwy.

Lathyrus latifolius. Broad-leaved Everlafing Pea. -Smith, 766. -P. July, Auguft.

Near Gyffin mill, about half a mile from Conwy.

$$
\text { . D } 2
$$

I.ATHYRUS 
Lathyrus palustris. Marß Everlafing Pea.-Smith, 767.-Eng. Bot. 16\%.-P. July, Auguft.

In moift paftures near Beddgelert, Caernarvonfhire.

Vicia sylvatica. Wood Vetch. - Smith, 768.-Eng. Bot. 79.-P. July, Auguit.

On the fouth-weft fide of Garreg Wen rocks, clofe to the wall that divides the Gan demefne, from that of Galltfaynan; -in the wood beluw Pont yr Allt Gôch, near St. Afaph; -and in the woods at Baron Hill, near Beaumaris, Anglefea.

Ornithopus perpusilizus. Common Bird's-foot.-Smith, 777. - Eng. Bot. 360.-A. May-Auguft.

In dry fandy places betwixt Pont y Gwydriel and Bettws Abergele, Denbighthire; - on the fouth-eaft end of Moel y Gaer, and the rocks above Llanyfydd, Denbighthire; - on the rock called 'Tuthill, behind the hotel at Caernarron.

Astragalus GLycypiyllos. Sweet Milk-vetch.-Smith, 779.-Eng. But. 203.-P. June, July.

On the hills about $\mathrm{Y}$ Spytty, Denbighthire.

Trifolium Glomeratọ. Round-beaded Trefoil.-Smith, 789.-A. May, June.

"On the hill in the front of Garn houfe; and on Henllan Hill, Denbighfhire.

Trifolium fragiferum. Strazuberry-beaded Trefoil. Smith, 791.-P. July, Auguft.

In moft of the paftures on the fea-coaft about Ty Newydd and Preftatyn, near Rliyddlan, Flinthire. 


\section{CI.ASS XVIII.}

\section{POLY ADELPHIA. - POLYANDRIA.}

Hypericum androsemum. Tutfas. - Smith, 800.-P. July, Auguft.

In a hedge near the Menai, betwixt Caernarvon and Llan. fair Ifcaer ; - in the woods at Glangwnna, near Caernarvon; -and amongt the rocks at the cataract, called Rhaiadr Dû, near Maentwrog, Merioneth hire.

Hrpericum dubium. Imperforate st. Fohn's Wort. Smith, 8u2.-Eng. Bot. 296.-P. July, Augun.

In the hedges about Beddgelert, Cacrnarvonfhire.

Hypericum homifusum. Trailing St. Fobn's Wart.Smith, 802.-P. July.

On the fides of dry banks about Caernarvon, not uncommon.

Hypericum montanum. Mountain St. Fobn's Wort.Smith, 803.-Eng. Bot. 37 I.-P. July.

In thickets in mountainous fituations, as near Penmaen Mawr;-on Burdd Arthur, abuve Llandonna, near Beaumaris, Anglefea.

Hypericum hirsutun. Hairy St. Fobr's Wort.-Smith, 804. - P. June, July.

In a wood below Garn coppice, near Denbigh; and in feveral other places in that neighbourhood.

Hypericum pulchrum. Small upright St. Fobn's Wort. -Smith, 804.-P. June, July.

On heaths, and in thickets in expofed fituations betwixt Caernarvon and Llanberis, not uncommon.

$$
\text { D } 3
$$


Hypericum elones. Marßs St. Folin's Wort.-Smith, 805.-Eng. Bot. 109.-.P. July, Augult.

, In borgs on the mountains betwixt Caernarvon and Llanberis; - and in fwampy places in Anglefea.

\section{CIASS XIX.}

SYNGENESIA. - POLYGAMIA EQUALJS.

Tragopogon porrifolius. Purple Goat's-beard.-Smith, 35 3. -Eng. Bot. 638.-T. porrifolium. With. 672.13. May, June.

In moif meadows in the parifn of Whitford, near Holywell, Fliutfhire.

Iedernors taraxici. Alpine Hedpprois. - Smith, 825.Hieraciun tarawici. With. 684. - P. July, Auguft.

In moilt lituatious near Llyn y $\mathrm{C}_{\mathrm{wn}}$, above Llanberis.

Mr. Griffith of Garn, whofe judgment on botanical fubjecis is of great weight, informs me that he believes this plant to be nothing more than a variety of Leontodon autumnale of With. 630. (Heclypnois autumnalis, Smith, 826). $\mathrm{He}$ compared his fpecimens taken from the bank of Llyn y Cirn, with thofe of Dr. Withering, that had been fent from abroad, and they exactly agreed. Mr.G. had, however, the precaution to take one of the roots; and the plaut, car cultivation, became much changed. The ftalk, which had hitherto been fimple, became much branched, and the calyx loft nearly all its woollinefs, whilt the leaves remained unaltered.-Under thefe circumftances he cannot fuppofe them dittinct fpecies.

Hisracium alpinum. Alpine fingle-fowered Hazuk-qued. Smith, 827.-P. July. 
On the rocks near Llyn y Cwn; - on Glyder; - and on the Trigfylchau rocks, near 'T'ull dû, above Llyn Idwel.

Hieracium murorum. Wall Hawkzeed.-Smith, 830. -P. July:

On rocks in Caernarvonfhire, not uncommon; and on the walls of Caftell Dinas B:ân, near Llangollen.

Hirracium sylvaticum. Wood Hawkweed.-Smith, 83 r. H. murorum B. Hudf. 345.-P. Augult.

Near the banks of Llyn y Cwn.

Cichorium intybus. Wild Succory. - Smith, 843.-Eng. Bot. 539.-P. July, Augutt.

In dry pattures near Llandudno, and the Great Orme's Head.

Serratula tinctoria. Common Saqu-wort.-Smith, 845.- Eng. Bot. 58.- P. July, Auguft.

In moift meadows near Beddgelert, common.

Serratula alpina. Albine Sazu-qurt.-Smith, 846.Eng: Bot. 599:-P. July, August.

'On the highett rocks of Clogwyn $Y$ Garnedd, very near the fummit of Snowdon, in plenty, but generally in in. acceftible fituations.

Carduus tenuiflorus. Slender-glonvered Thille.-Smith, 849.-Eng. Bot. 412.-A. June, July.

On the dry bank fides near Caernarvon caftle.

Carduus marianus. Milk Thifle.-Smith, 851.-A. Auguft.

About Diferth cafle, near Rhyddlan; - and Caergwrle caftle near Mold, Flinthire, 
Carduus heternithltus. Melancloly Thifle.-Smith, 853.-Eng. Bot. 675.-C. Helenjides. With. 702.Hudf. 352.-P. July, Auguft.

In the afcent from Llanberis to Glyder.

Santolina maritima. Sea Cotton-weed-Smith, 860. -Eng. Bot. i 4 I.-P. Auguft, September.

On the fandy fea Morc near Abermenai ferry, Anglefea. in plenty.

SINGENESIA - POLYGAMIA SUPERFLUA.

Artemisil Makitima. Sea Vormquood.-.Smith, 86 4. P. Auguft.

On ihe fouth weit coaft of Anglefea.

Gajphalum Diorcum. Mountain Cudrueed.-Smith, 36y.-Eag. Bot: 26́7.-P. May July.

On the rocks in the upper part of the cleft of Tull Dat, atove Llyn Idwell.

Ginarealiem syluticum. Highland Cudqued. - Smith, 869. - P. tuguf.

On Cader Idris ?

Gnaphamuni Recters. Upright auod Cudweed.-Smith, 870.-Eng. But. 124.-1'. A uguft.

On Wirdy Bank Hill, near Denbigh.

Conyza sejarross. Pinzemin's spikenard.-Smith, 875. B. July, AuguR.

Near the ruins of Lafingwerk alsbey ; - on Diferth cafle hill; - fides of the road betwist Caernarvon and Pont Seiont ; and near the houfes at Moel y Don ferry, Anglefes. 
ERIGeron aCre. Blue Fica-bane. - Smith, 877.-B. July - September.

On the ruins of Denbigh cafle;-fandy ground betwixt Rhuddgaer and Llanddwyn, Anglefea; -and on the Meadow in Rutlin caftle.

Senecio visco us. Stinking Groundsel.-Smith, 882.Ling. Bot. 32.-A. July-October.

On the banks of Bala lake, Merionethfhire.

Senecro sylvaticus. Mountain Groundfel._Smith, 883. - Eng. Bot. $718 .-$ A. July.

On bank fides near Pont Aberglâflyn.

Sinicio tenuralius. Hoary Ragruort.-Smith, 884.-Eng. But. 574. - S erucifoilus. Hudf. 366.-P. July, Augun.

In the wood below Garn coppice, near Denbigh;-By the road fide miclway betwixt Llanerch and Dymeirchion, near St. Alaph.

Aster tripolium. Sia Star-wort.-Smith, 838... Eng. But. 87 -P. Augult, September.

In a falt-water ditch near Rhyddlan, by the road fide lealding from thence to St. Afaph; - on the marhy coatt near Dulas lay, Anglefea.

Sutidago virga-atria. - Common Golden-rad.-Smith, 839. - P. July.

A Variety of this plant, the S. Cambrica of With. 7.8, and Hudr. $3^{67}$. and generally called Welfh Go'den rod, is found in great plenty on all the mountains around the village of Llauberis.

InUla Helenium. Elecampane,-Smith, 891.-P. July, Auguft. 
In moilt meadows and paftures betwixt Denbigh and St. Afaph.

InULA CRITHmoInes. Samplire-leaved Flea-baxe.-Smith, 393.-Eng. Bot. 68.-P. Auguft.

Salt mar:hes near Llanddwyn, Anglefea.

Cineraria miegrificra. Muntain Flia.quort.-Smith, 895--Eng. Bot. I 52.-C. Alpina, Hudr.

On the cliffs near Hulylicad.

Antriexis nobilis. Common Chamanile-Smith, 902. P. Augut, September.

In a field near Trefriw houfe, not far from Llanfaclog, Angiefea;-and on Farlech marh, plentifully.

\section{$=$ \\ CIASS XX. \\ GYNANDRIA. - DIANDRIA.}

Orchis girolia. Butterfy Orclis. - With. 21.-Eng. Bot. 22.-P. June.

In moit meadows in various parts of Carnarvonhire; and near Bala lake, Miftrionethfhire.

Orchis pyramidals. Pyrcmidal Orcbis.-With. 23. - Eng. Bot. 1 io.-P. June, July.

In Gluddacth wood, near Conwy.

Orchis conopsea. Srecet Orchis. - TVith. 28.-Eag. Bot. 10.-P. June.

In a frnall bog fouth of Mr. Lloyd's new garden at Wýgfair, near St. Afaph;-and in the meadows of Creiddin, below the rocks of Llandudno.

Satrfium viride. Frog Satyrion or Oribis.-With. 30. - Eng. Bot. 94.-- P. July, Auguft. 
In meadows between the boufe of Frôn, and the upper wood, in the parifh of Miold, Flintthire.

Satrrum almidust. White Satyriont. With. 31.-Eng. Bot. 505.-P. June, July.

In moit meadows near Lord l'enriyn's fate quarries, in Nant Frangon;-in Glyn meadow betwixt Cwm y Clo, and Lolbadarn cafle, in plenty; - and near L.lyn Cowlid, in the mountains north-wett of Capel Curig.

Ophrys ovata. Common Trvay blade. - With. $3:-P$. May, Jure.

In the wood at Maes $y$ Porth, near Newhorongh, Anglefea.

Ophrys spiralis. Ladies Fraccs. - With. 33.-Eng. Bot. 541.-P. July-September.

In old paftures of Caemarronnire, and Anglefea.

Serapias latifolta. Ciommon Feliebrine. - With. 40. Eng. Bot. 260.-P. July, Augůt.

Bỵthe road fide leading from Henllan to Ilanfannan, Denbighthire, about two miles from the former place.

Seratias palustris. Marfo Hellebrine.-Eng. Bot. 270. S. Longifolia...W With. 41.-P. July, Auguit.

In marhy meadows in Caernarvonfhire, and Anglefea.

\section{$\Longrightarrow$ \\ CI.ISS XXI. \\ MONCECIA.-MONANDRIA.}

'/anaicheldia pazust ris. Horned Pond-weed.-With. $\sigma$. -A. July.

In many of the ditches and itagnant waters of CarnarvonShire and Anglefea. 


\section{MONECIA.-DiandRIA.}

Lemina gibia. Lagf Duck's meat.-With, 44--A. July, Auguft.

In ditches on the north-weft fide of Rhyd marfh, near Rhyddan Flinthire.

\section{MIONCECIA. - TRIANDRIA.}

Sparganium natans. Floating Burr-reed.-With. 112. -Eng. Bot. 273.--S. Simplex B.-Hudf. 401.-P. July.

In the pools of Llanberis;-and in Llyn Ogwen, betwixt Bangor and Capel Curig.

CAREX drorca. Small Seg.-With. 86-Eng. Bot. 543, -P. June, July.

In a bog at the upper end of Llyn Idwel.

Carex pulicaris. Flea Seg.-With, 86.-P. June.

- At the botiom of a field called Gerddi, oppofite to Garreg WVen rocks, near Garn, Denbighßhire.

-Carèx arenaria. Sea Seg.-With. 90. f. 20.-P. June.

On the fandy beach near Preftatyn, Flinthire;-and in Conwy marh, Caernarvonthire.

Carex intermedia. Soft Seg.-With. gi.-C. dificho. Hudf - P. May, June.

In moift meadows in the parifh of Rhyddlan, betwixt $\mathrm{PwI}$ y Gurfog and the fea.

Carex pendula. Pendulous Seg-With. 96.-P. May, Inne.

Near the rirulet on the weft fide of Garreg Wen rocks, in the parifh of Ienllan, Denbighhire.

CAREX 
Carex strigosa. With. 96.-P. April, May.

In Garn Dingle, in a wet place near the bottom of the glade.

Carex flava. Yellow Seg, var. 2.-With. 99.-P. June, July.

On the borders of Llyn Idwel.

Carex distans. Loofe Seg.-With. I00.-P. May, June.

On Llanyfydd mountaik, Denbighhire;-and Buckley mountain, Flinthire.

Carex atrata. Black Seg.-With. 105,-P. JuneAugult.

On the mountains about Llanberis, plentifully.

Carex pilulifera. Pill-bearing Seg. -With. $105 .-P$. April-June.

On a dry bank oppofite to the village of Llanberis, in the afcent from thence towards Llyn y Cwrl.

Carex rigida. Hard Seg.-With. I06.-P. April, May. On Crib y Ddefcil, near Llanberis.

Carex ampullacea. Beaked Seg.-With. Iro.-C. ver ficaria. Hudf. 4I3.-P. May-July.

In the bogs near Llyn Idwel.

MONCECIA.-TETRANDRIA.

LitTorella lacustris. Plantain Shore-weed. -With. 194.-Eng. Bot. 468.-P. June-Auguft.

On the bank of the fouth end of Bala lake. 


\section{MONCECIA-PCLYANDPIA.}

Potericm sanguisorba. Upland Bumet. -With. 493. -Eng. Bot. 860.-P. April, May.

On the road fides near Beaumaris, Anglefea, -and on Diferth caftle hill, Flintfhire.

\section{CLASS XXII.}

DICECIA.-DIANURIA.

Salix mergacea. Herbaceous Willogu. - With. 48.-S. July.

Ont the higheft rocks of Snowdon.

\section{DICECIA.-TRIANDRIA.}

Exretrum nigrum. Black-berried Healb.-With. i 76 . -Eng. Bot. 526.-S. A pril, May.

On all the mountainous moors of Caernarvonfhire and Merionethhire, in plenty.

\section{DICEIA.-TETRANIRIA.}

Viseum alburs. Mifetoe. With. 203.-S. May.

On apple-trees in various places betwixt Chirk and Llan. gallen; -in the village of Broughton, Flintihire.

DICECIA.-OCTANDRIA.

Rhoplora rosea. Tellow Refe-zuort.-With. 389.-Erg. Bot. 508.--P. June, July.

On the racks about Tull $D \hat{\text { un }}$ above Llyn Idwel; - on Clogwyn y Garnedd;-and on Craig y Cac, Cades Idris.

DICECIA, 


\section{DICECIA.-MONADELPHIA.}

Juniperus communis. Cammon Funiper Tree.-With. 599.-S. May.

On the rocks of the Great Ormes Head.

Variety. Alpine dwarf Funiper.-With. 599.

On the rocks near $\mathrm{Lyn}$ y $\mathrm{Cwn}$, above Llanberis.

\section{$=$ \\ CI.ASS XXIII. \\ POLYGAMIA.-MUNOECIA.}

Atriplex portulacoides. Sea Purfane.-With. 274. -Eng. Bot. 26r.-S. July, Auguft.

On fea-rocks on the fouth.wett coatt of Anglefea.

Atriplex laciniata. Frofed Orache.-Witil. 274.Eng. Bot. I65.-A. July, Auguft.

On the fouth-weft coaft of Anglefea.

Atriplex IItToralis. Grafs Oracbe.-With. 275.Eng. Bot. 708.-A. Auguft.

On the fouth-weft coaft of Anglefea.

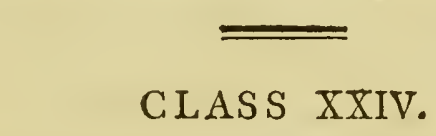

CRYP TOGAMIA. - MISCELLANEE.

Lycopodium clavatum. Common Club-mo/s. - With. 756. Eng. Bot. 224. - P. July, Auguft.

In dry ground on the mountains of Caernarvonfhire and Merionethinire, not uncommon. 
Lycopodum selaginordes. Prickly Club-mo/s. - Wirh. 757. - P. June-September.

On the ligher pasts of the mountains about Llanberis, common.

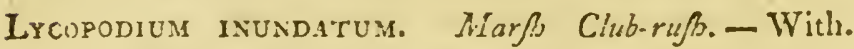
758. - Eng. Bot. 233.--P. June-September.

On moift heaths, and turfy bogs, near Capel Curig, Caernarvonthire.

Lycoponium selago. Fir-leaved Club-moss.-With. 758. Eng. Bot. 233.-P. April-October.

In moift places on nearly all the mountains about Llanberis; - on Snawdon; - and on Cader Idris.

Lycopodium annotinum. Welfh Club ma/s.-With. 759. -P. June-September.

Mr. Griffith of Garn, near Denbigh, found this plant in great abundance about ten ycars ago, near Llyn y Cwn, growirg along with Funiperus communis : but, although he has often fought for it fince, he has never been able to find it.

Lrcopodrum alpinum. Alpine Club-mo/s.-With. 759.Eng. Bot. 234.-.P. July-October.

On all the mountains of Caernarvonfhire, common.

Pilularia grobulifera. Pill-wort. - With. 759.-Eng. Bot. 521 .-P. June-September.

In wet places about two miles from Mold, on the north fide of the road leading from thence to Cheftcr, near Watt's Dyke.

IsOETES LACUSTRIS. Quill-zuort. - With. 760.-P. MaySeptember.

In Fiynnon Frech, a fmall pool in the mountains betwixt Llanberis and Snowdon, plentifully; and in Llyn y Cwn. 


\section{CRYPTOGAMIA.-FILICES.}

Ophioglossum vulgatum. Adder's Tongue.-With. 761 . Eng. Bot. ro8.-P. May, June.

In moift places in Maes y Porth wood, near Newborough, Anglefea.

Osmunda lunaria. Moonzuort.-With. 762. - Eng. Bot. 3 8.-P. May-July.

In old paltures in various parts of 'Anglefea.

Osmunda Regalis. Flozvering Fern. -With. $; \sigma_{3}$.-Eng. Bot. 209.-P. June-Auguft.

In watery places about Pont Aberglâsllyn;-and on the fides of ponds in Anglefea.

Acrostichum septentrionale. Forked Maidnn Hair. -With. 764.-P. July.

In fiffures of the rocks near the fummit of Carnedd Llew. elyn.

PTERIs crispa. Stone Fern.-With. 764.-Ofmunda crippa. Hudf. 450.-P. Augut-September.

On the rocks of almoit all the high mountains of Caernarvon hire and Merionethhire.

Blechnum spicant. Rough Spleenzurt.-With. $76 ; \cdot-$ Ofmunda Jpicant. Hudf. 450.-P. July-September.

On the heaths betwixt Caernarvon and Llanberis.

Asplenium scolopendrium. Hart's Tongue. - With. 766. -P. Aúgut, September.

In fhady places about Conwy cafte;-under the rocks, among the buhes, by the fide of the river, betwixt Caernarvon caftle and Pont Seiont.

VOL. II.

E E

Variety. 
Variety. With the leaves jagged at the edge, and curled Near a petrifying fpring by the fide of a rivulet, at the bottom of Garn Dingle, three miles from Denbigh.

Aspienium ceterach. Common Splénnuort. - With. $76 \%$. -P. May-Oetober.

On moift rocks on the north-welt coafts of Caernarvonfhire $\checkmark$ and Anglefea.

Asplenium trichomanes. Common Maiden Hair.-With. 768.-Eng. Bot. 576.-P. May-October.

On old walls and rocks, common.

Asplenium viride. Green-ribbed Maiden Hair.-With. 768.-P. June-September.

On the moit rocks in the cleft of Tull Dư, above Llyn Idwel; - on Clogwyn du'r Arddu ;-and on Clogwyn 5 Garnedd.

Asplenidu marinum. Sea Splecnwort.-With. 769.Eng. Bot. 392.-P. June-Septamber.

On the Llanddwyn rocks, Anglefea;-and on the rocks of Prieftholme ifland.

ASPLENIUM RUTA MURARIA. Wall Rue.-With. $769_{0}-$ Eng. Bot. 150.-P. June-September.

On old walls throughout North Walcs.

Asplenium adiantum Nigrum. Black Maiden Hair.With. 7705-P. April_CAober.

On walls and thady places about Caernarvon and Bangor, very luxuriantly.

Polypodium vulgare. - Var. Cambrigum. Wel乃 Polypody. - With. 773.-P. June-Odtober.

Near Gloddaeth, Caernarvonfhire. 
Polypodium ronchitis. Spleenzuort Polypody. - With. 773.-Eng. Bot. 797.-- P. Niay-September.

In clefts of rocks on the higher parts of Clogwyn y Garnedd.

Polypodium ILvense. With. 774. - P. July - September.

Among the higheft rocks of Clogwyn y Garnedd.

Polypodium arvonicum.-With. 774.-Acrofichum ilvenfe.-Hudf. 45 I.-P. July - September.

The habitat of this uncommon plant is thus defcribed in Ray's Synopfis: - "It grows on a moitt black rock, almolt at the top of Clogwyn y Garnedh, facing the north-weft, directly above the lower lake." - I fought for it feveral timęs, but in vain. W. $B$. polypodium PHEGopteris. Wood Polypody. - With. 775 . P. June-October.

In the clefts of moift rocks, near Tull Dû.

Polypodium oreopteris. Heath Polypody - With. $775^{\circ}$ -P: \helypteris. Hudf. 457.-P. July-October.

On the heaths betwixt Caernarvon and Llanberis, common. Polypodium theltateris. Marfs Polypody.-With. 776.-P. July-October.

In a moit dell near the village of Llanberis,

Polyponium aculeatum. Prickly Polypody. - With. 777. -P. June-October.

Amongt the bufhes by the river fide betwixt Caernarvon caftle and Pont Seiont.

Polypodium filix femina. Female Polypody. - With. 778.-P. June-September.

In thady hedges, not uncommon. 
Polyodium cristatum. Crefed Polypody.-With. 778 .

P. June-September.

In thady places, and on old walls, not uncommon.

Polypodium Rheticum. Stone Poljpody.-With. 780.-

P. June-September.

On rocks near Ffynnon Velen, above Llanberis;-and near the fummit of Glyder Bach.

Cyathea fragile. Cup Fern.-Polypodium fragile.With. 779.-Hudf. 459.-P. June-September.

In clefts of the rocks of the highelt mountains of Caernarvonhire, common.

Crathea incisa. Laciniated Cup Fern.-Eng. Bot. 163. P. trifidum. With. 779 .

On the rocks about Tull Dü.

Hymenophylium tunbridgense. Tunbridge Goldilocks. -Eng. Bot. 162.-Trich. tunbridgenfe. With. 781.Hudf. 46 1.-P. May-October.

In a hady dell in the vale of Llanberis. 


\section{N D E X.}

A

Vol. Page

Aber,
- , caftle at, now demolithed, -
${ }_{-}$, ferry from, into Anglefea,
- , womantic glen near,
Aberconwerfall at,

Abergeley, - - - -

Aber Mawr, or Barmouth, _ _ _. _ ii. 23

Abermenai,

ferry-boat, particulars of the lors of,

Abermule,

Aberyltwith,

Abren, or Sabrina, ftory of,

Album monatterium,

A'ca Arctica,

\begin{tabular}{|c|c|}
\hline & Vol. Page \\
\hline & - i. 150 \\
\hline & $-\quad$ i. \\
\hline & $-\mathrm{i}$. \\
\hline & - i. 158 \\
\hline - & - i. 152 \\
\hline & - i. 110 \\
\hline & - i. 105 \\
\hline - & - ii. 23 \\
\hline & - i. 418 \\
\hline & - i. $28 \mathrm{r}$ \\
\hline & - ii. 66 \\
\hline & - ii. 50 \\
\hline & - ii. $\sigma_{3}$ \\
\hline & - ii. $9^{8}$ \\
\hline & - i. 350 \\
\hline
\end{tabular}

Alleluia victory, at Maes Garmon, near Mold, account

of,

Allt $\mathrm{Dû}$, nate quarry near Llanberis,

Amlwch,

- fmelting hurfes, and port,

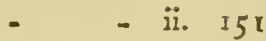

- $\quad$ - i. 226

- - i. 308

- $\quad$ - i. 319

Anecdote of Dr. Cole, and Mrs. Edmunds, at Chefter, io $2 \mathrm{i}$ of James I, on his expedition to Chefter, i. 23 of tir Robert Pounderling, - - i. yl of the removal of the body of Owen Gwynedd

from Bangor cathedral,

- of an old woman's node of getting into her

houfe whenever the had millaid the key of the doors io $2 z Q$ E $₹ 3$

Anecdote 
Anecdnte refpceting the frege of Béaumaris cafle, in

the civil wars of Charles I., of prince Llewelyn and his greyhound, - i. 363 of fir Howell y Fwyall and his battle-ax, i. 405 of fir John Owen, - - _ - i. 407 of Hugh Lloyd Cynfael, - - i. 460 of the valour of David ap Ifan ap Einion, ii. II of fir Richard Herbert, - - - - ii. ib. of the valour of Edward Herbert, efq. grand.

father of the celebrated lord Herbert of Chirbury, ii. 60 of fir Jolun Trevor, mafter of the rolls in the

rcign of James II. - $\quad$ - $\quad$ - $\quad$ - ii. I16

- of two gentlemen at Llanwehllyn, near Bala, ii. I 98 of the difcovery of a murderer, - - ii. 210 refpecting the furrender of Shrewfoury to the

carl of Richmond, afterwards king Henry VII. - ii. 240 Anecdotcs of Mr. Pennant,

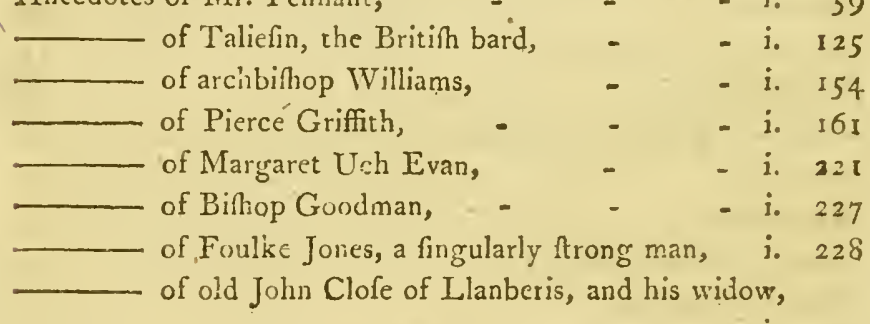

i. 237

of Caddy of Cwm Glâs,

- i. 242

of Dafydd ap Givilym, the Welin bard,

i. 289

- i. 323

- ii. 76

- ii. 110

- ii. 177

of Llywarch Hên, the Welih bard, - ii. 189

- ii. 211

- of Roger Kynafton, -

Alkmund's church, in ShrewBury, - - ii. 219 of Churchyard, the poet, - $\quad$ - ii, 243

Anglefea, excurfion from Caernarvon into, $\quad-$ i. $27 \delta$ Angleftag 
Anglefea, once joined to Caernarvonhire, - - i. 279 - ferries into, - - - - - - i. 280 - the refidence of the ancient Wellh princes, i. 289 - copper mines, - - - - - i. 319 - marine productions of, - - - - i. 340 Arran, a mountain near Snowdon, - - i. 356 Arran Benllyn, - - - - - ii. 193-196 Arrenig mountains, near Bala, - - - - ii. 193 Arvon, the fourteen privileges of the men of, - i. 203 St. Afaph,

- i. 74

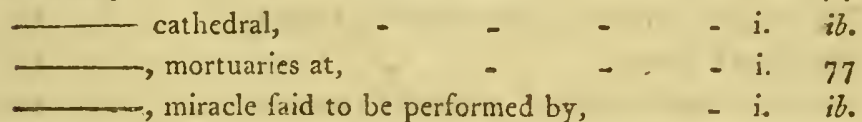
Affach, an old Wcilh cultom fo called, - - ii. 262 Afterias glacialis, - $\quad$ - $\quad$ - $\quad$ - i. 420 Avon Vawr, - $\quad$ - $\quad$ - $\quad$ - ii. 27

Backgammon, etymology of, Bagillt, Bala, - lake,

- overfowings of,

- excurfion round,

Bangor, or Bangor Vawr, in Caernarvonhire, cathedral,

- cantle,

- - - houfe of friars preachers at, - - parih church, Bangor ferry,

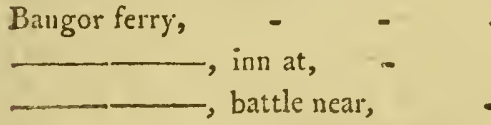

E E 4
- ii. 260

- i. 42

- ii. $10^{2}$

- ii. 193

- ii. 195

- ii. $i b$.

- i. 166

- i. 167

- i. 168

- i. 167

- i. 171

- i. ib.

- i. $i b$.

- i. ib.

- i. 173 Bangor 


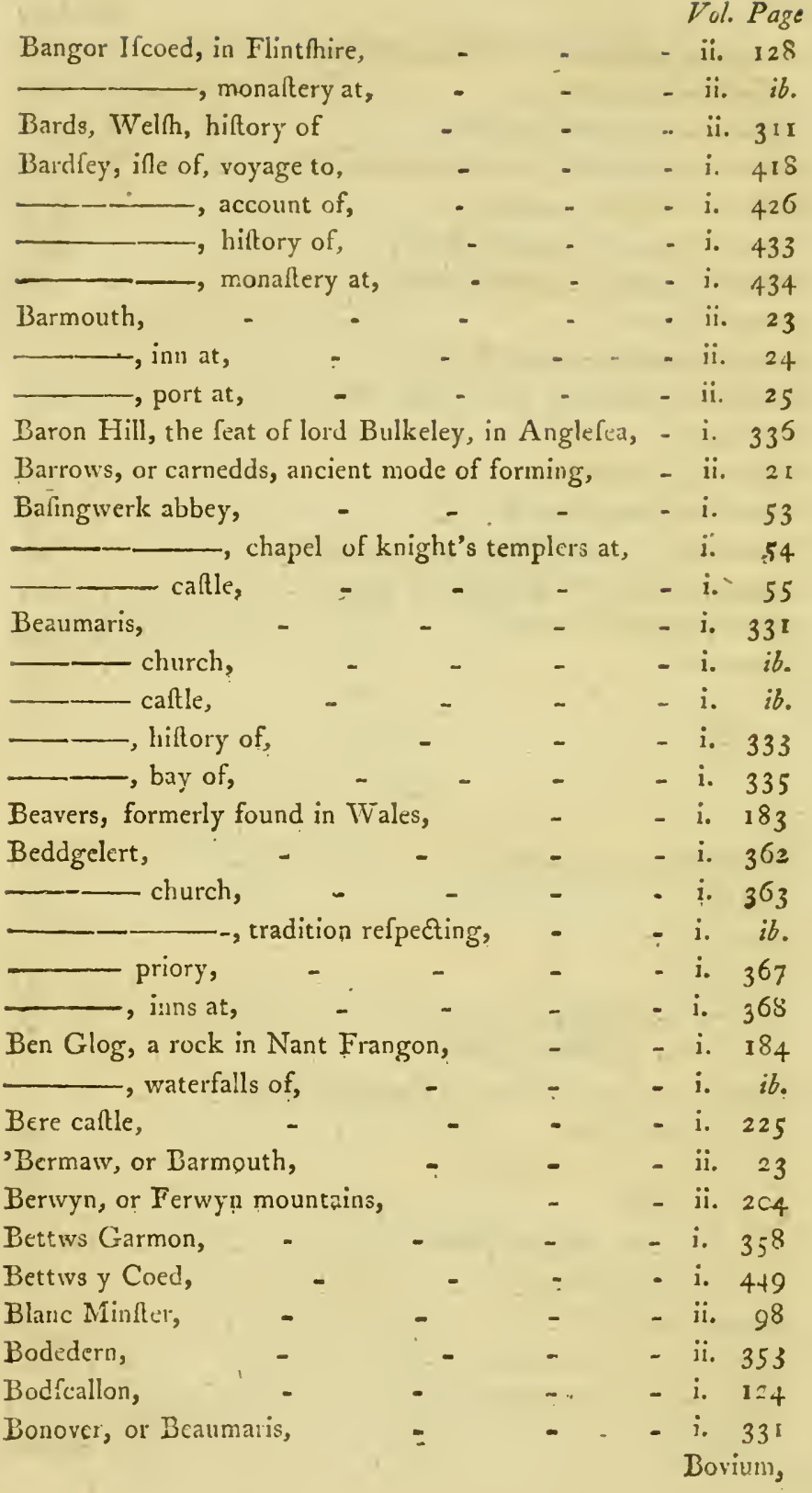


Bovium, or Bonium, the Roman ftation, at Bangor

Ifcoed, in Flinthire,

Braich Ddû,

Braich y Cafn, -

Braich y Dinas, an ancient fort on the fummit of Penmaen Mawr,

Breiddin, or Wreiddin hills, in Montgomeryfhire,

Bretton,

Bromfield and Yale, lordhip of,

Buccinum lapillus,

Bundling,

Bull baiting, at Chefter,

BwIch Cwm Brwynog,

Bwlch Glâs,

Bwlch Tyddiad,

Bwrdd, or Bwrth Arthur,

Bychton,

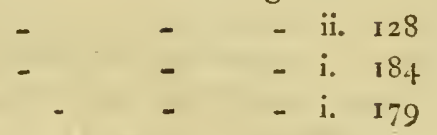

- i. $\quad 47$

- ii. 92

- ii. 345

- ii. 144

- i. 419

- ii. 282

- i. $1 \mathrm{I}$

- i. 262

- i. 260

- ii. IT

- ii. 405

- i. 59

\section{C}

Caddy of Cwm Glâs, anecdotes of,

Cader Ferwyn,

- Fronwen,

Cader Idris, afcent to the fummit of,
- i. 242

- ii. 204

- ii. $i b$.

- ii. 44

Cadman, an adventurer on ropes from church fteeples, killed in a defcent from the fpire of St. Mary's church

in Shrewfbury,

Caunant Mawr, a cataract near Llanberis,

Caer Collwyn, or Harlech catlle,

Caer Cufteint,

Cacr Cybi,

Caer Gai,

Caergwrle,

Caernarvon,

-, inn at,
- ii. $22 \mathrm{r}$

- i. 226

- ii. 8

- i. 204

- i. 306

- ii. 200

- ii. 145

- ii. 146

- i. 191

- i. ib.

Caernarvon 
Caernarvon harbour,

\section{caftie,}

- i. 193

_- privileges and government of,

- i. 194

- i. 201

Caernarvonfaire feuds in the fifteenth century,

- i. 408

Caer Rhûn,

Cacr Segont,

Calamine found in Flinthire,

Cancer bomarus,

Cantref Gwaelod,

- i. 136

Canwyll Corph,

Capel Curig, vale of,

Cardigan bay, , inn at,

Carnedds, account of,

- i. 204

- i. 58

- i. 430

- ii. 20

- il. 278

- i. 439

- i. 440

- ii. 20

Carnedd Llewelyn, a high mountain in Caernarvonhire,

i. $18 \mathrm{I}$

Carreg, near Holywell,

tradition refpecting,

Carreg y Big, near Dolwyddelan,

Carreg y Saeth,

Caftell Cidwm,

—_, tradition refpecting,

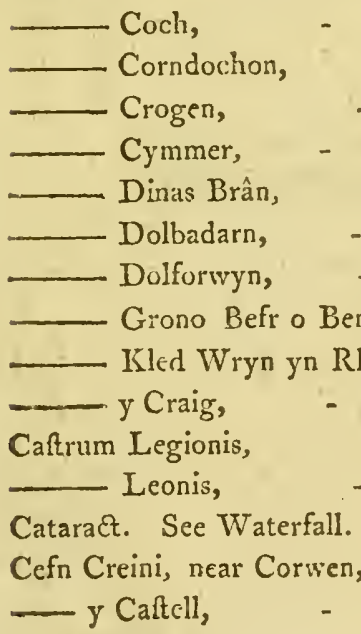

- i. $i b$.

- i. 59

- i. 445

- ii. 16

- i. 360

- i. 365

- ii. 89

- ii. 199

- ii. 114

- ii. 36

- ii. 168

- i. 224

- ii. $6 \mathrm{t}$

- ii. 193

- i. 94

- i. 91

- i. 15

- ii. 140

- ii. 183

- ii. 92 Char, 
Char,

Chefter,

$\longrightarrow$, rows at,

- walls of,

___ roodee at,

- cathedral,

\section{$+$}

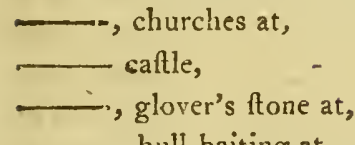

- bull-baiting at,

\section{- , hiftory of,
$\longrightarrow$,
,-
-}

Chirk,

- church,

- caftle, police of,

\section{-, aqueduct at,}

Churchyard the poct, Thort account of,

Cilgwyn fate quarries,

Clawdd Coch,

Clawdd Offa,

Clogwyn du'r Arddu,

- y Garnedd, part of Snowdon,

Clwyd, vale of,

Clynog, church,

Cockles, modes of taking,

Coed Euloe, in Flinthire, defeat of king Henry II. at, i. 34 Coelcerth,

Conovium of the Romans,

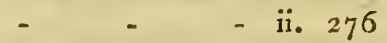

Conftables Sands, near Cliefter, tradition refpecting,

Conwy,

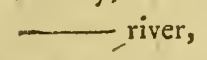

river,

pearl filhery in,
Vol. Page

i. 223.359

- i. 1

- i. 2

- i. 3

- i. 4

- i. 5

- i. 8

- i. 9

- i. 10

- i. 11

- i. $i b$.

- i. 13

- i. 14

- i. 22

- i. 23

- i. 25

- ii. 110

- ii. $i b_{\text {. }}$

- ii. 113.

- ii. 110

- ii. 243

- i. 393

i. 251.385

- ii. 95

- i. 247

- i. 253

i. 72.78

i. 400

- i. 401

- i. $43 \mathrm{I}$
- ii. 276

- i. 110

i. 55

- i. 110

- i. 106

- i. 108

Conwy 


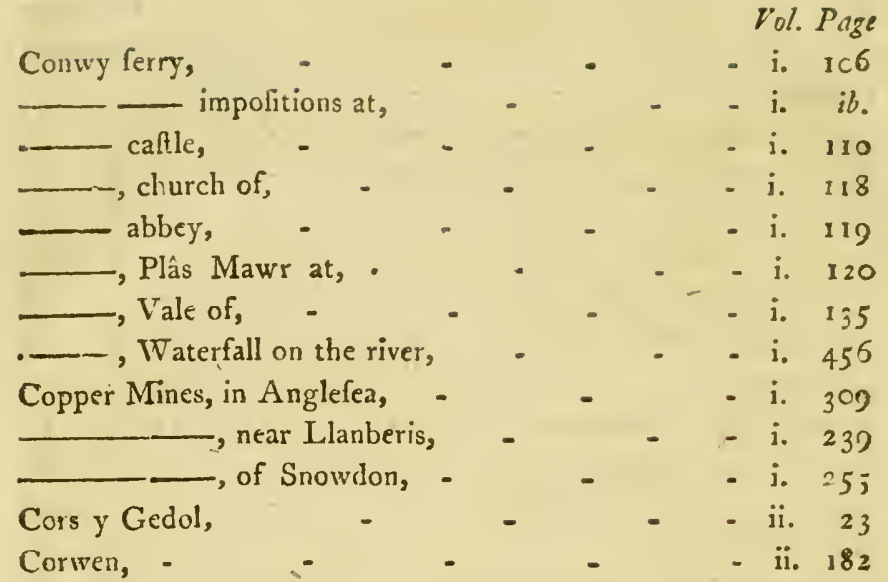

Counterpoint, the laws of, not known among the an.

cient Welh Bards,

Courthip, Welth mode of,

Crabs and lobfters, mode of taking,

Craig Breiddin,

Craig y Cai,
Crategus aria

Creigiau Hysfa Bengam,

- yr Eryri
- ii. 334

- ii. 282

- i. $4 ; 0$

- ii. 92

- ii. 46

- ii. 205

- i. 147

- ii. 288

- i. 253

Creiddin, a hundred of Caernarvonfhire, near Conwy,

excurfion round, plants found in,

Crib Coch, part of Snowdon, -y Ddefcil,

Ciiccaeth, caftle,

Cromlech, etymology and ufe of the,

- mode of erecting,

- near Plâs Newydd in Anglefea,

Cromlechs, lift of, in Anglefea,

Crucis, vale of,

Crwth, Welfh mufical infrument fo called, Crwth Trithant,
- i. 122

- i. 133

i. $28.25 \mathrm{I}$

- i. $25 \mathrm{I}$

- i. $4=4$

- i. $i b$.

- i. $j 00$

- i. 302

- i. 300

- i. 303

- ii. 160

- ii. 330

- ii. 233 Cucking 
Curcking ftool, at Montgomery,

Curig, a Wellh Saint,

Cuftoms, and manners,

Cwm Bochlwyd,

- Brwynog,

Bychan, near Harlech,

- Dyli,

Glâs,

Idwel,

- ii. 75

- i. 441

- ii. 244

- i. $27 \mathrm{I}$

- i. 247

- ii. 15

- i. $3^{83}$

- i. 244

- i. 269

-

- Ilan,

Maentwrog,

Nancoll,

- y Clo,

Cylch Cyngrair, or Druidical Circles,

Cynfael, waterfalls, of the,

Cynwyd, waterfall of the,

- i: ib.

- i. $3^{8 x}$

- i. 62

- ii. 18

- i. 218

- ii. 15

- i. 459

- ii. 186.

D

Dafydd ap Gwilym, the Welih bard, memoranda of, i. $28 \mathrm{~g}$ Dear-dor, phenomenon fo called,

Dee, river,

\section{$\longrightarrow$, fource of,}

- derivation of name of,

Dee, valley of the,

Denbigh,

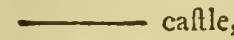

, White Friary at, $\begin{array}{llr}- & \text { - ii. } & 196 \\ \text { - } & \text { - i. } & 24\end{array}$

$\begin{array}{lll}- & \text { - ii. } 196 \\ \text { - } & \text { - i. } & 24\end{array}$

- ii. 200

- ii. ib.

- ii. 175

- i. 94

- i. 95

- i. 103

Derfel Gadarn, immenfe wooden image of, at Llander-

fel, near Bala,

Devil's Bridge, near Beddgelert,

- near Havod, in Cardiganhire,

Diganwy,

Dinas Brân caftle,

Dinas Dinlle,
- ii. 187

- i. 370

- ii. 51

- i. 123

- ii. 168

- i. 397

Dinas 
Dinas Emrys,

Diodlys, a cuftomary gift at Welh funerals,

Diferth,

- ii. 287

caltle,

Dolbadarn caftle,

Dolforwyn caftle,

Dolgelle,

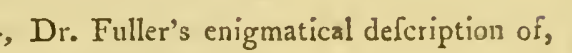

- i. 90

- i. $i b$.

- i. 224

- ii. $6 \mathrm{t}$

- Dr. Fuller's enigmatical defcription of,

- ii. 29

- ii. $i b$.

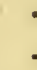

Dolmelynllyn waterfall, near Dolgelle,

Dolwyddelan cafte,

Downing, village,

Druidical Circles,

Druids, hiltory of the,

Drws Ardudwy,

Drws y Coed,

Dulas Bay,

Dwynwen, the Welih Venus,

Dwyryd, river,

Dyffryn Clwyd, or Vale of Clwyd,
- ii. $3^{\circ}$

- ii. $i b$.

- ii. $3^{6}$

- i. $44 \mathrm{I}$

- i. $41^{6}$

- i. 39

ii. $15-19$

- ii. 311

- ii. 17

- i. $39^{2}$

- i. $3^{2} 3$

- i. 296

- i. 462

-i. $72-78$

E

Edeirneon, vale of,

Eglwys Rhôs,

Eifl or Rival Mountains,

Eifleddfod,

E

Elifeg, pillar of, near Valle Crucis abbey,

Ellefmere.canal,

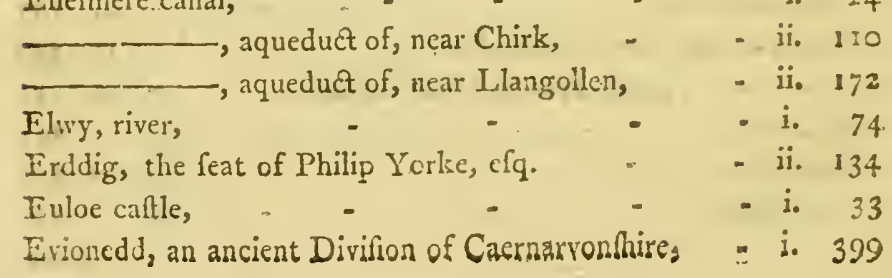

- ii. 185

- i. 132

- i. 400

- ii. $32 \mathrm{I}$

- ii. 161

- i. 24 
F

Vol. Page

Farndon,

Ferry-boats from Cacrnarvonhire to Anglefea, loft, i. 280

Feuds,

- i. 443

- , in Caernarvonfhire during the fifteenth century, i. 408

Ffellining,

, vale of,

Ffynnon Dyfnog,

Ffynnon Frêch,

Filh, monocular,

Flint,

- church,

-. gaol,

- cattle,

Floating ifland,

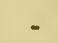

(1)

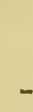

Friars, near Beaumaris,

Frwd y Pennant, waterfall fo called,

Funerals, Welh,
- i. $45^{8}$

- i. 462

- ii. 156

- i. 259

- i. 268

- i. $3^{6}$

- i. ib.

- i. $i b$.

- i. 37

- i. $3^{8}$

- i. 362

- i. 339

- ii. 56

ii. $285,-i, 240$

G

Games, ancient Welfh,

Gannoc,

Garn,

Dingle,

Garreg Wen,

Gerald Barry, or Giraldus Cambrenfis,

Gildas Nennius,

Giraldus Cambrentis,

Glangwna, near Caernarvon,

- $\quad$ - ii. 260

- i. 123

- ii. 369

- ii. $3 \sigma_{5}$

- ii. 374

- ii. 445

- ii. 13 I

- ii. 445

Glâs Llỵn,

- i. 356

Gleiniau Nadroedd, or fnalke's beads,

- ii. $5^{6}$

Gloddaeth,

- ii. 94

Glyder Vawr, afcent to the fummit of,

- i. 133

- i. 274

Glyder 
Glyder Bach, afcent to the fummit of, Vol. Page

Glyder and Trivaen mountains, afcent to the fummit:

$$
\text { of, }
$$

Glyndwr, Owen, memoranda of,

Glynn bridge, near Corwen,

Glyn Dyfrdwy,

Glynllivon, the feat of lord Newborough,

Goodman, bihop, anecdotes of,

Goronwy Owen, memoranda of,

Gorphwysfa, near Llanberie,

Gorfeddau,

Gors y Caffeg,

Grifith, Pieree, ancedotes of, -

Gwern Einion,

Gwydir, near Llanrwit,

Gwynant,

Gwyndy,

Gwyniadd, a fpecies of alpine fin,

Gyrn Goch, a mountain near Clynog,
- i. 266

- ii. 177

- ii. 183

- ii. 175

- i. 400

- i. 227

- i. 323

- i. 246

- ii. 15

- ii. $3^{8} 3$

- i. 161

- ii. 18

- i. 2450

- i. 376

- i. 305

- ii. 194

- i. 402

$\mathrm{H}$

Halkin,
Harlech, -




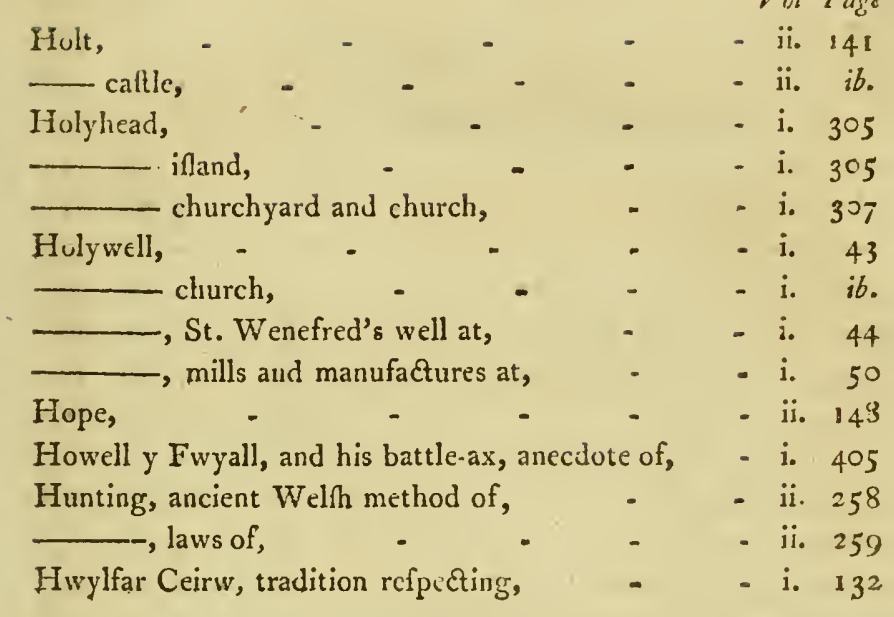

\section{I}

Idris, giant, tradition refpecting, - - - ii. $4 \mathbf{I}$ Jones, Foulke, a remarkably ftrong man, anecdotes of, i. 228 Ifland, floating, - - $\quad$ - $\quad$ - $\quad$ - i. $3^{62}$ Jumpers, a fingular fect of calvinifical methodifs, i. 208

K

Kemmer, or Y Vanner abbey, near Dolgelle, - ii. $28.3^{2}$ Kinmael, - - $\quad-\quad$ - $\quad$ ii. 348

Knockers in mines, a fuppofed kind of aërial beings,

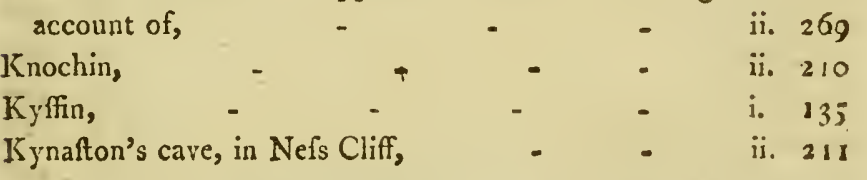

I

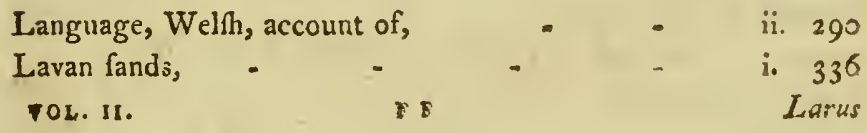




\section{Larus marinus,}

Lead Mines, near Holywell,

Leeks, why worn on St. David's day,

Llanaber,

Llanberis, vale of,

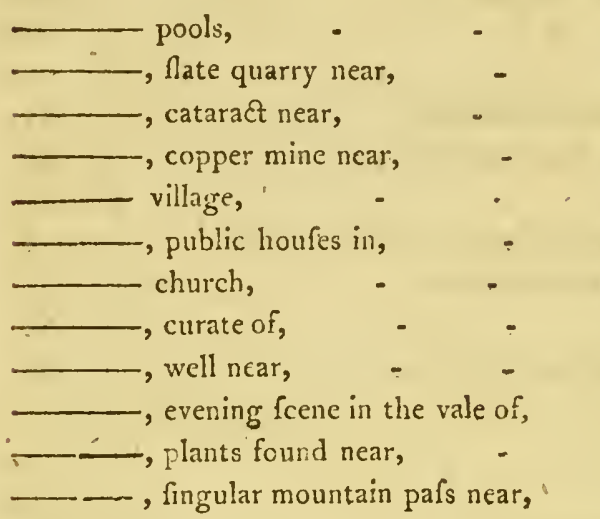

Llanbublic church,

Llandaniel,

Llanddwyn abbey, in Anglefea, -

Vol. P'age

- i. 260

- i. 58

- ii. 281

- ii. 23

i. 216.222

- i. $2: 2$

- i. 224

- i. 226

- i. 230

- i. 234

- i. 235

- i. 238

- i. ib.

- i. 241

- i. 275

- i. 276

; i. 244

- i. 193

- ii. 353

- i. 295

i. 295.419

Llanderfel,

- ii. 186

Ilandinam,

- ii. 60

Llandrillo,

- ii. 186

Llandudno,

- i. 131

- i. 128

Illandululas,

rocks, tremendous feene at,

- i. 105

Llandwrog,

- ii 372

Llandwye,

- ii. 356

Ilandygai,

- i. 153

- i. $i$.

- i. 160

- i. 345

Llandyfilio church, on an ifland in the Menai,

- ii. 375

Llandyfilio hall,

- i. 299

Llanedwen, in Anglefea,

feet

long, buried here,

- i. 298 
Ilan Egweft, or Valle Crucis abbey,

Llanelian church, in Anglefea,

- ii. 162

- i. 320

practices at,

Llanelltyd,

Llan Elwy, or St. Afaph,

Llanfaelog,

Llanfair, in Anglefea,

Llanfawr,

Llangedwen, vale of,

Llangollen, hall,

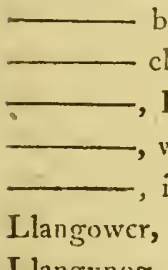 \\ Llangynog,}

__, flate quarries at,

Llanhaiarn, lead mines at,

Llanrhaiadr, near Denbigh, Llanrlıaiadr yn Mochnant,

Llanrwet,

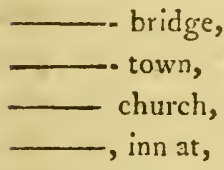

Llanfannan, Llan St. Siôr,

Llanvaes, in Anglefea, priory of,

Llanvihangel, in Anglcfea,

Llanwchllyn,

Llanycil,

Llanydloes,

church,
- i. 322

- ii. 28

- i. 74

- ii. 377

- i. $3: 3$

- ii. 189

- ii. 209

- ii. $i b$.

- ii. 166

- ii. $i \cdots$.

- ii. $i b$.

- ii. 167

- ii. 172

- ii. 174

- ii. 106

- ii. 204

- ii. ib.

- ii. 205

- i. 402

- ii. 155

- ii. 207

- i. 449

- i. 451

- i. 452

$\therefore$ i. $45^{2}$

- i. 455

- ii. $3^{34}$

- ii. 348

- i. 339

- ii. 353

- ii. 198

- ii. $35 x$

- ii. 57

- ii. ib.

I lanydloes, 
Llanydloes, manufactures at,

Llanygenedl,

Llanymynech,

hill, cavern in,

Vol. Page

Llechog,

Llechwedd y Rè,

Llewclyn and his dog, tradition refpecting,

Lliewedd,

Lloyd, Hugh, Cynfael, anecdote of,

Llugwy, waterfall of the,

Llwyd, Humphey, thort account of,

Llyfni, river,

Llŷn, promontory of, excurfion into,

Llyn Aled,

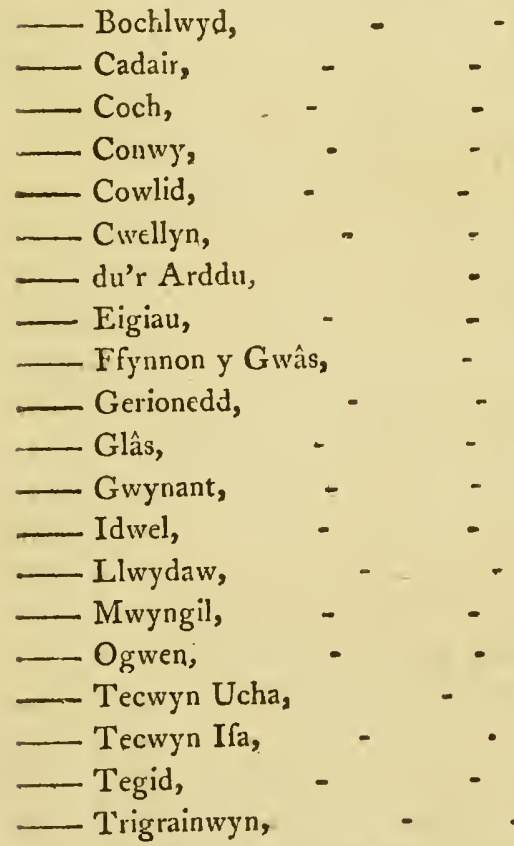

- ii. $5^{8}$

- ii. 353

- ii. 93

- ii. $i b$.

- ii. $i b$.

- ii. $i b$.

- i. $25 \mathrm{r}$

- i. 248

- i. ${ }_{3} 63$

- i. 251

- i. 460

- i. 448

- i. 103

- ii. 372

- i. 396

- ii. $3^{64}$

- i. 271

- i. 362

- i. 386

- i. 449

- i. 138

- i. 359

- i. 247

- i. 338

- i. 262

- i. 138

- i. 386

- i. 382

- i. 269

- i. 260

- ii. $4 \mathrm{I}$

- i. 388

- ii. 5

- ii. 6

: ii. 192

- ii. 41

- ii. ib. 


\section{N D E X.}

Llyn y Cae,

Cwm Bychan,

Cwm Glâs,

$-\mathrm{Cwn}$,

- Dinas,

- Dywarchen, Nadroedd,

Yr Avange,

Llyniau Nantlle,

Vol. Page

Llywarch Hên, the Welih bard, memoranda of,

Lobfters and crabs, the modes of taking,

- ii. 46

- ii. 16

- i. 260

- i. 267

- i. $3^{8 \mathrm{r}}$

- i. $3^{62}$

- i. 366

- ii. 57

- i. 390

- ii. 189

Lyons,

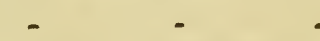

- i. $43 a$

- ii. 140

\section{M}

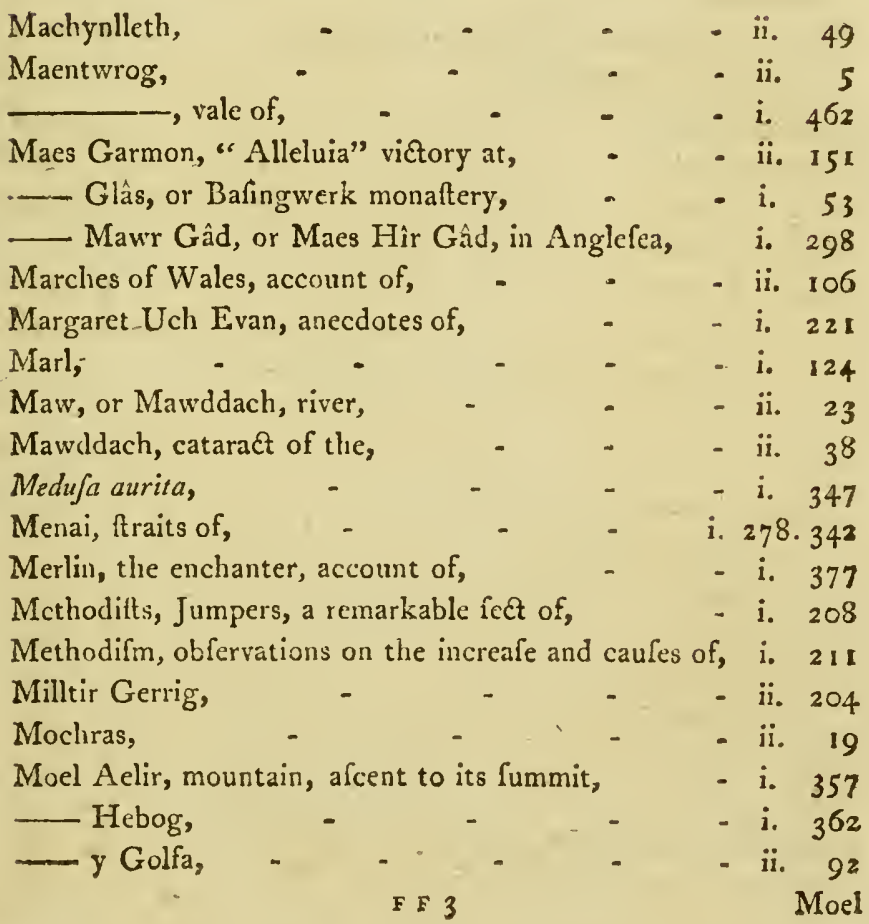


Moel y Don ferry,

Vol. Pege

- battle at,

Mold,

- church, caftli,

Môn, or Mona, Anglefea,

Mona copper Mine, -

Montforj bridge,

Montgomery,
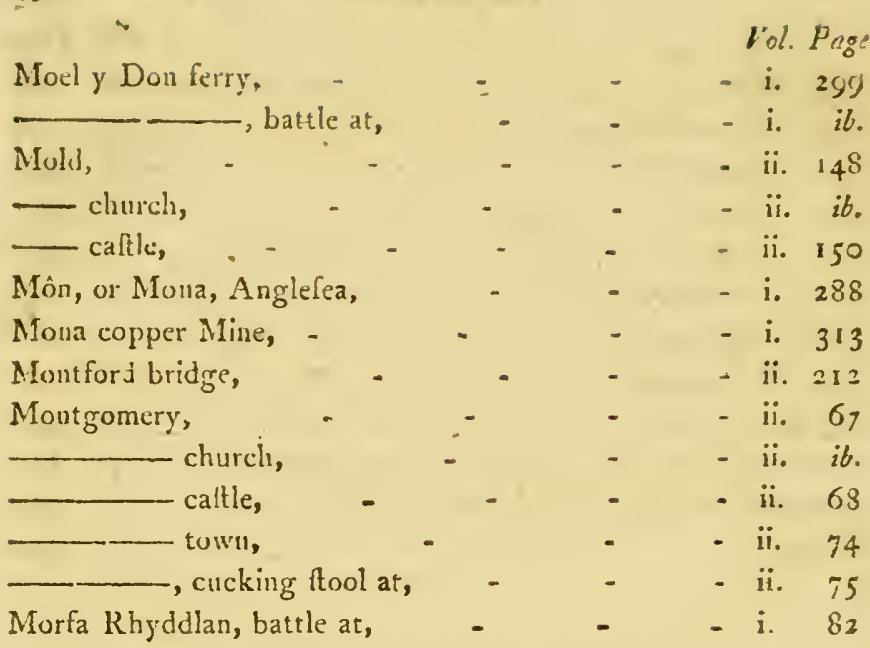

, Welth air fo cailed. See fpecimens

of mufic.

Mufic, Welf, obfervations on its antiquity,

- ii. 334 character of,

Wya margariifera,

Mynydd Mawr,

- Mocl,

Myrudin Eirrys,

- - ap Morfigh,

Wyllt,

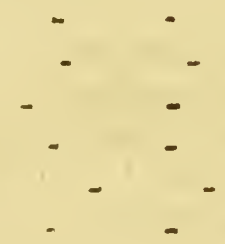

$\mathrm{N}$
Nantberio, or the vale of Llanberis,

Nant Bwlch yr Kriarn,

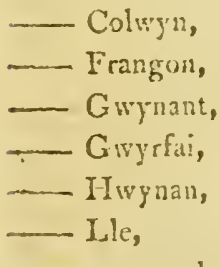

pouls, excusfion to,
- ii.

- i, 108

- i. 356

- ii. 47

- i. 379

- i. $3^{80}$

- i. $i b$.

\footnotetext{
s,
} 
Owen Giwynedd, anecdote reipecting the removal of his body out of Bangor cathedral, Oyiters, mode of catching,

- i. 170 - i. 43 i

Pabell Llywarch Hên, Padarn, a Welfh faint, tradition refpecting, Paris mountain, in Anglefea,

- ii. 190

- i. 224

- mine,

- i. 309

Patclla valgata,

Peatl fifhery, in the river Conwy,

- mufcle, account of,

Peat, mode of conveying down mountains, Penallt,

Penmachno,

Penmaen Bach,

Peumaen Mawr,

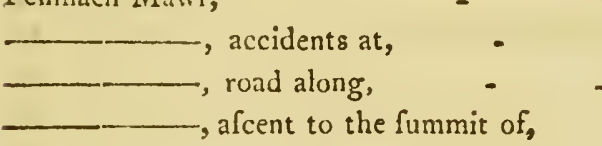

- i. $350-3 \div 3$

- i. 421

- i. 108

- i. $i b$.

- i. 268

- ii. 49

- i. 457

- i. 142

- i. ib.

- i. $\quad 1 / 3$

- i. 144

- i. 146

- i. 147

Penmaen Rhôs,

Penmon priory, in Anglefea,

Penmorfa,

- i. 105

- i. 340

Pennant, Mr. memoranda of,

Penrliyn caftle, the feat of Lord Penrhyn,

-i. 407

- i. 59

- i. $16 \mathrm{t}$

- , hiftory of,

- i. $i b$.

- fine view from the grounds of,

- i. 164

- i. 165

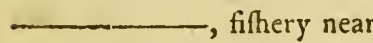

- i. 166

Pentraeth, in Anglefea,

- i. 329

Pen y Cader,

- ii. 46

Pen, y Llan,

- ii. 123

Pibcorn, a Welih mufical inftrument, fo called,

- ii. 333 
Vig y Fầ,

- ii. 375

f'imblemere,

- ii. 193

Piltyll Rhaiadr,

- ii. 208

, whimfical painting of,

- ii.

Piltyll y Cain,

- ii. $3^{8}$

Plants of Crcirdin,

- i. 133

-_-, found near Difertl,

- i. 91

-., on Snowdon,

- i. 353

-. found near Tull Dù Llanberis, Welm, catalogue of,

- i. 276

Pliks Gwyn, in Auglefea,

- i. 363

Plàs Mawr, at Conwy,

- i. 329

Plàs Newydd, Anglefea, the feat of the earl of Uxbridge,

\section{cromlech near,}

$\longrightarrow$, the feat of lady Eleanor Butler and Mifs

- i. 120

- i. 300

- i. ib.

- i. 307

Ponfonby, near Llangollen,

Plynlimmon mountain, -

Plygain ancient cuftom fo called,

Pont Aberglânlyn,

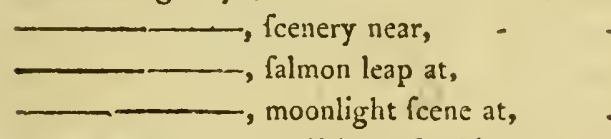

- ii. 167

- ii. 54

- ii. 280

- i. 370

- i. $i b$.

- i. 372

- i. 375

- i. 372

Pont ar Monarch, or Devil's bridge, near Havod in Cardigan?hire,

Pont Cynwyd,

Pont y Cyffyllte, near Llangollen, aqueduct at,

Pont Porthlwyd,

Pont y Glyn, near Corwen, cataract at,

Pont y pair,

Pont y Pandy, waterfall near,

Pool caftle, or Powis caftle,

Pool Ceris,

Porthaethwy, or Bangor Ferry,

caftle at,
- ii. 5 t

- ii. 203

- ii. 172

- i. $13^{8}$

- ii. 183

- i. 447

- i. 456

- ii. 87

- i. 279

- i. 171

- i. 173

Porth 
Porth Leidiog,

Porthynll;an, - $\quad$ - $\quad$ - $\quad$ - $\quad$ - i. 403

Port Penrkyn, - - - - - i. 176

- - innat, - $\quad$ - $\quad$ - $\quad$ - i. ib.

- manufactory of writing flates near, - i. $1 ; 7$

\section{- \\ - i. ib.}

flate quarries,

Pounderling, fir Robert, anecdote of, - - i. 91

Powel Dr.

Powis caftle,
Preftatyn,
Prielttholme ifland, voyage to,

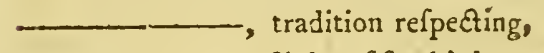

- flight of fea-birds at,

-

Puffins, account of birds fo called,

- ii. II9

- ii. 87

- ii. 88

- ii. 366

- i. $34^{2}$

- i. $34 \mathrm{~s}$

- i. 349

- i. 350

- 'i. ib.

Pulpit Hugh Lloyd, Cynfael near Ffeftinoig, - i. 460

Pwllheli,

i. 404

Q.

Queen Hope,
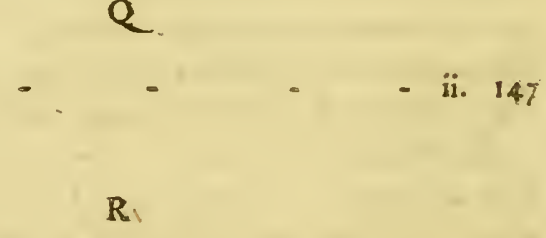

Red wharf bay, Anglefea,

- i. 333

Rlaiadr Ben Glog, in Nant Frangon, - _ _ - i. 184

Cwm Dyli,

Cynwyd,

- i. 328

- ii. 186

Dû, betwixt Tanybwlch and Harlech,

- ii. 4

- ii. $3^{6}$

Mawr, betwixt Conwy and Llanrwit,

- i. 138 Rhaiadr 
Rhaiadr Mawr, near Aber,

- i. 152 - y Craig Llwyd,

- i. $45^{6}$

Rhiedd, in Anglefea,

Rhil Marfh, in Finthire,

Rhitta, a giant, tradition refpecting,

Riniwejug, -

Rhual,

Rijyd eque, irs, and Rby'd Pedefire, two fords in Caer-

- ii. $3^{3}$

- i. $44^{8}$

- i. 298

- ii. 369

- i. 181

- ii. 203

- ii. 151 narvonfhire, Rhyaddan,

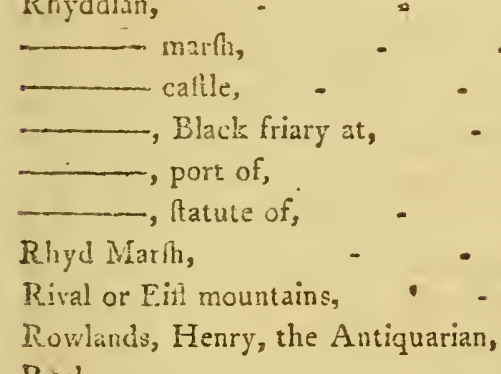

- i. 397

- i. 80

- i. 8 z

- i. 83

- i. 89

- i. $i b$.

- i. 8 I

- ii. $3^{i 0}$

- i. 400

Ruabon, church and monuments,

Ruthin,

Ruthin, church, caftle,

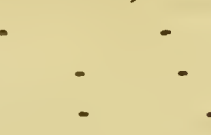

- i. 268

- ii. 118

- ii. 16

- ii. 156

- ii. ib.

- ii. 857

\section{S}

Eacheverel, Dr. memoranda of,

Salmon leap, near Pont Aberglânlyn,

Salmo alpirus,

Salno lavaretus,

Sarn Badrwyg,

Sarn Helen,

Sarn y Bwch,

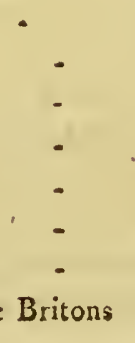

- ii. 110

- i. $37 \%$

- i. 359

- ii. 194

- ii. 19

- i. $44^{2}$

- ii. 19

Sazon alphabet properly belonging to the Britons

- ii. 304 Saxon 


\section{Vol. Page}

Saxon columns and arches, curious fpecimens of, in St.

Jolu's church, Chefter,

Segonitum,

Seiont, river,

Sciantiorum portus, of Ptolemy,

Seteia portus,

Severn, fource of river,

......., origin of name,

Sheep, extraon Hury in lance of activity in,

Shewfury,

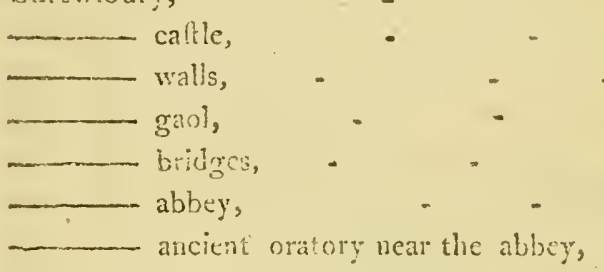

churches, -

, St. Ciles's cinuch in, -

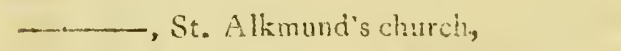

- St. Mary's church,

__._. Si. Juliais's church,

_........ St. Chad's churcl,

_.... New St. Chad's church,

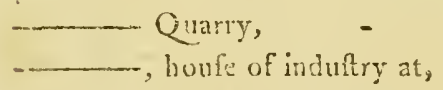

-...., homfe of Aufin friars,

- houfe of Francifcan friars,

- , houfe of Dominican fiars,

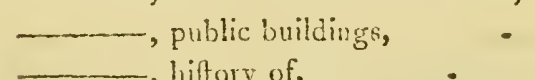

\section{- fweating ficknefs in,}

, remarkable events at,

Siamber Wen, near Dilerth, Siate quaries, lord Penrhyn's, near Ilanberis, in the parion of Llanlly fui,
- i. 9

-i. 204

- i. 205

- i. 207

- i. 59

- ii. 55

- ii. 63

- i. 429

ii. 213

- ii. $i b$.

- ii. 214

- ii. 215

- ii. $i b$.

- ii. 216

- ii. 217

- ii. 218

- ii. $i b$.

- ii. ib.

- ii. 220

- ii. 222

- ii. ib.

- ii. 223

- ii. 224

- ii. ib.

- ii. 233

- ii. ib.

- ii. $i b$.

- ii. 234

- ii. $2 j 6$

- ii. 241

- ii. 296

- i. 92

- i. 179

- i. 226

- i. 393 Slate 
Slate quarries, near Llangunog, and dangerous modic of conveying the flates from the mountain into the vale,

Snowdon, excurfion to the fummit of, from Dolbadarn calle, near Llaubcris,

$$
\text { - i. } 247
$$

- excurlion to the fummit of, from Llanberis, i. 259 -_, excurfion to the fummit of. from Llyn Cwellyn,

i 262

- excurfion to the fummit of, from Beddge.

\begin{tabular}{l} 
lert, \\
\hline , height of, \\
\hline , view from, \\
\hline ,
\end{tabular}

\section{$\mathrm{T}$}

Taliefin, the Britifh Bard, fhort account of, Tal y Moel fre, or Tal y Voel fre,

- i. 125

Tanybwlch,

-, fea fight at,

- i. 287

Teganwy,

Terming, a Welfh drunken cuftom,

Tommen y Bala,

- i. $i b$.

Tradition refpecting an image of the Virgin Mother

found on the Roodee, near Chefter, _ _ _ Ethelred, king of Mercia, - i. 9 Conftables's fands, near Chefter, i. 55 Tudno, and Cybi, two Welh faints, i. I 32 
'Tradizion refpecting Hwylfar Ceirx', on the Orme's Head,

Rhit a, a giant, who is faid to have

lived on Carncdil Llewelyn, - - - i. 181

Padarn, a Welh faint, - i. 224

Cwm ldwel, - - i. 269

a woman fixtcen fect long, buricd at

Llaneçwen, in Anglefer, - $\quad$ - - i. $29^{8}$

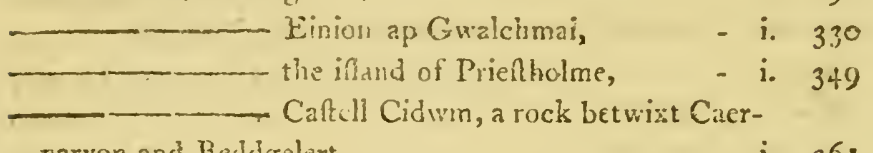

narvon and Beddgelert, - - - i. $36 \mathbf{1}$

Ilewelyn and his dog, - i. 363

the erection of Pont A berglasllyn, i. 3.72

- the monks of Bardfey, - i. 434

Pubbles, - - $\quad$ - $\quad$ - ii. 41

- Ogo, a cavern in Llanymyncch hill,

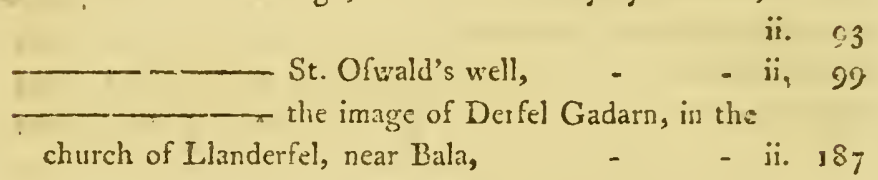

St. Alkmunds church, Shrewibury,

ii. 220

Traethan Grwylltion,

Traeth Mawr, and 'Traeth Bach, - ' - - i. 370

Trefarthen, in Anglefea,

Trefriw, nẹar Llaṇwft,

Trefaldwyn,

Tre Newydd,

Trevor hall,

- i. 251

Trevor, fir John, Mafter of the Rolls in the reign of

James II. anecdote of,

- ii, 116

Trivaen, or Y Trivaen, mountain, afeent to the fummit

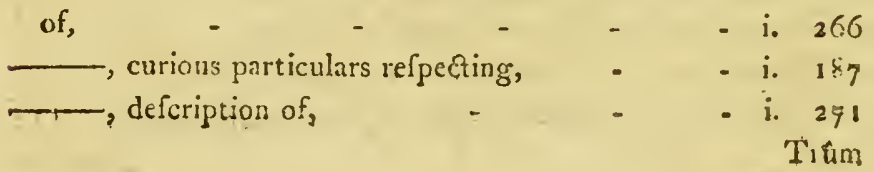


Tudno and Cybi, Welh faints, tradition refpecting, i. I?2 St. Tudiral's iflands,

- i. 437 Tull Dû, near Llanberis,

- amazing cataract at,

Tuthil, a rock at Caernarvon,

Twrch, vale of,

- river,

Ty 1) û, near Llanberis,

Tyfilio,

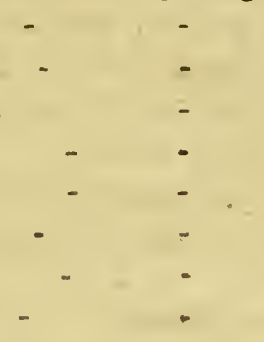

- i. 270

- i. $i b$.

- i. 192

- ii. 196

- ii. $i b$.

- i. 227

- ii. 133

V

Vale of Crucis,

Valle Crucis abbey,

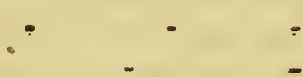

- li. 160

Y Vanner, or Kemmer abbey, near Dolgelle,

- ii. $16 z$

Vapour, mephitic, near Harlech,

ii. $2^{2} \cdot 3^{2}$

Virnwy, river,

- ii. 12

Voryd, river,

Yreiddịn, or Breiddin hills,

- ii. 93

- i. 397

- ii. 92

\section{IV}

Viarren mountain,

IVaterfall betwixt Conwy and Llanrwft, called Rhaiadr

- ii. 345

Mawr,

called Rhaiadr Mawr, near Abẹr,

- i. 138

- i. 152 of the river Ogwen, called Rhaiadr Ben Glog,

i. 184

near Dolbadarn caftle, Llanberis, called Cau-

nant Mawr

at T'ull $\mathrm{Dû}$, near Llanberis,

at Nant mill, betwixt Caernarvon and Beddge-

lert,

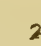

- i. 226

- i. 270

- i. 359 Wạterf̣all 
Waterfall a few miles from Beddgclert. called Rhaiadr

y Cwm Dyli,

- i. $3^{82}$

of the river Llugwy, near Llanrwf, called

Rhaiadr y Wenol,

- i. 448

of the river Conwy, near Llanrwit, called

Rhaiadr y Craig Linyd,

- i. 456

of the Cynfael, near Ffeltiniog,

- i. 459

betwixt Tanybwlch and Harlech, called Rlaaiadr

Dú, near Harlech,

- ii 4

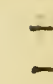

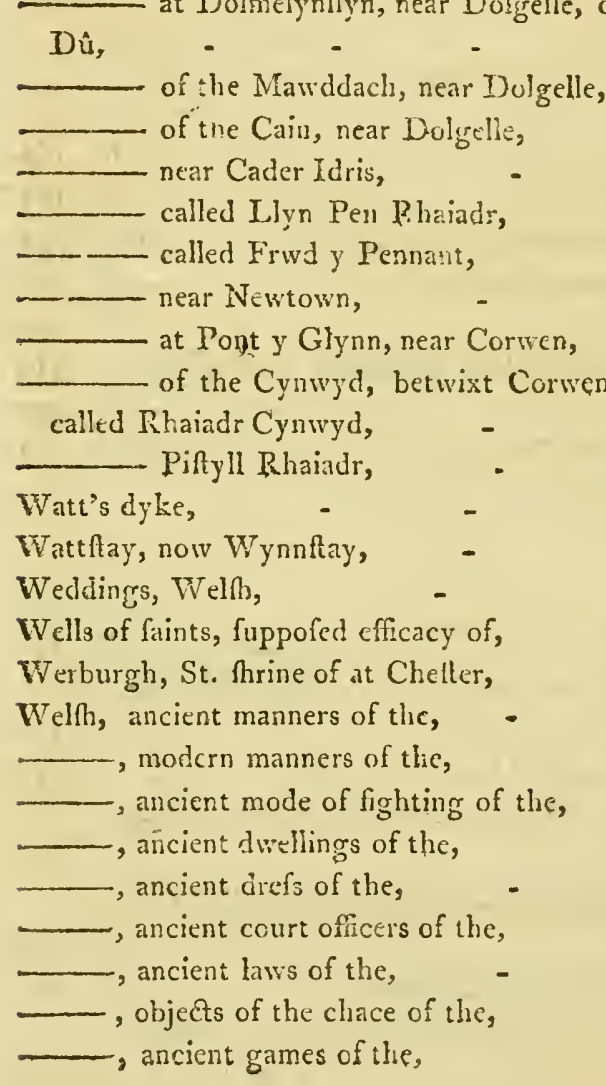

at Dolmelynllyn, near Dolgrelle, called Rhaiadr

- ii. 36

- ii. $3^{8}$

- ii. $i b$.

ii. $45 \cdot 48$

- ii. 50

- ii. 56

- ii. 61

- ii. 183 of the Cynwyd, betwixt Corwen and Bala,

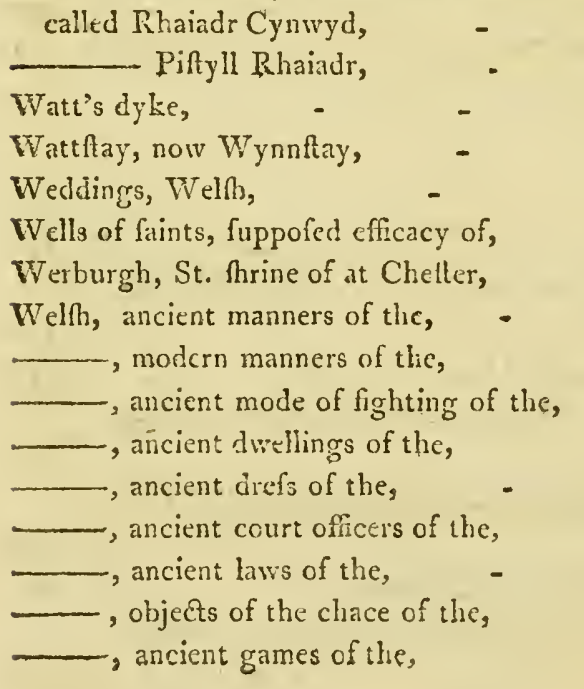

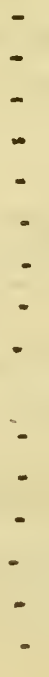

- ii. 186

- ii. 208

.. j. 56

- ii. $12 i$

- ii. 289

- ii. 279

- i. 5

- ii. 244

- ii. 264

- ii. 246

- ii. 247

- ii. 248

- ii. 249

ii. 253.257

- ii. 258

- ii. 260 Wellh 
Welth and Englifh contefts after the infurrection of

Owen Glyndwr, - - - - n - - ii., 260

—_, modern character, and manners of the, - ii. 264 .

- irafcibility of the, - - - ii. 265

$\longrightarrow$ food of the, $\longrightarrow \quad$ ii. 257

$\longrightarrow$, drefs of the, _. _ _ _ - ii $i b$.

- curiofity of the, _. . . - ii. 268

- fuperftitions of the, - ' - - ii. $i b$.

- mode of courthip of the,

- ii. 282

- weddings of the,

- ii. 283

- , funerals of the,

$-$

- i. 283

- offerings at funerals of the, alphabet, mufic, character of, language, account of, poetry, character of, and Hebrew languages compared, and Greek languages compared, - marches, account of, -

- 1. 240.11 .285

- - ii. 286

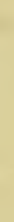

Weln Pool,

Wenefred's well and chapel, at Holywell,

, legend of,

Whitchurcl,

Whitford, a Roman pharos in the parih of,

Williams, archbifhop, memoranda of,

Witches,

Wrexham,

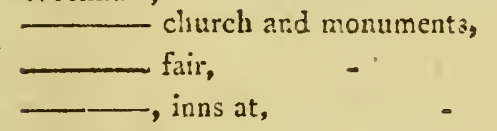

- ii. 296

- ii. 342

- ii. 290

- ii. $29 \mathrm{r}$

- ii. 293

- ii. 295

- ii. 106

- ii. 85

-i. 44

- i. 45

-i. 103

- i. 59

- i. 153

- ii. 275

- ii. 134

- ii. 135

- inns at,

- ii. 138

- ii. 139

Wye, fource of the river,

- ii. 55

Wynnitay, the feat of fir Watkin Williams Wynne, ii. 121

\section{$Y$}

Y Caer Wen, near Corwen,

Yew trees in church-yarcls, conjectures refpecting,

- ii. 183

ii. 123

TOL. I1.

$G \mathrm{G}$

Y'nys 
Ynys Enlli, or Bardfey ifland, - . - i. 433

Ynys Seiriol, or Priettholme ifland, - - i. 349

Yr Eryr, a difeafe fo called, how faid to be cured, - ii. 277

Yr Wyddfa, the higheft point of Snowdon, _ - i. 253

Yr Wyddgrûg, or Mold, - - . ii. 150

Yipytty Evan, - - - - i. $45^{8}$

, hofpital of knights of St. John of Jeru-

falem at, - - - - i. $i b$.

Trivaen, a mountain in Caernarvonfhire, i. $187.266 .27 \mathrm{I}$

Y Vanner, or Kemmer abbey, near Dolgelle, - ̈̈. 32

THE END. 


\section{E R R A T A.}

\section{Page Line}

\section{VOL. I.}

11. 22. for more read fo

24. for than read is

103. 14. put out who

109. 14. after form, infert be

II6. S. for gentleman read gentlemen

159. 21. after intimate infert that

170. 20. for his read this

214. 17. for lays read lay

235. 13. put out agains

298. 13. for or read nor

299. 8. after in infert thefe

330. 28. for or read nor

338. 7. for fanding as it does read being as it

353. 1. after them for, infert :

378. 23. put out Enirys, or Ambrofius

382. 10. for and read who

391. 12. for tolerable read iolerably

415. 26. for only read almo,t

416. 5. for the read $a$

445. 17. infert the) after feen inftead of cafle.

VOL. II.

45. I6. after another infert cafcade

57. I. for Avange read Avangs

11. 4. after havs infert bal. 


\section{BOOKS printed for T. N. LONGMAN and O. REES, - No. 39, Paternofter-Row.}

7. A JOURNEY from EDINBURGH through Parts of NORTH BRI'AIN ; containing Remarks on Scottifh Landfcape; and Obfervations on Rural Economy, Natural Hiftory, Manufactures, Trade, and Commerce : interfperfed with Anecdotes traditional, literary, and hiftorjcal; torether with Biographical Sketches, relating chiefly to Civil and Ecclefiatical A ffisirs, from the Twelfth Century down to the prefent Time. By ALIXANDER CAMPBELL, Efq. In 'T'wo Volumes 4to, embellihed with Forty-four Engravings by Aikin, Medland, Jukes, \&c. from Drawings made on the Spct, of the Lakc, River, and Mountain Scenery of Scotland. Price Four Guineas, Boards.

“Thefe Volumes may be truly faid to afford a confiderable fhare of entertainment and incormation. The engravings which embellith this work, ( 4 in in number, ) and which are all made from drawings by the Author, are in general crainently beautiful, and reflect great credit on the taite aid gocnius of the artifts."

Montbly Revierv, Nov. I8cz.

"The work before us unites plealure, information, and inftruction, far beyond the 'l'ours which ufwally come before Reviewers; they indeed exlibit a muclel on which 'Tours hould be written, in order to unite amufement and entertainment with utility... The engravings, befides embellifhing by the bauty of their exerution, illuttrate by the juftnefs of the defign, and the happinefs of imitacion."”

Anti facobin Review, OZ. 1 \&oz.

2. A JOURNEY into SOUTH W M.ES, through the Coun. ties, of Oxford, Warwick, Wrorefter, Hereford, Salop, Stafford, Buckingham, and Hertford, in the Year I 799. By GEORGE IIPSCOMB, Efq. Dediented by Permiffion to Lord Nelfon. In One Volume, 8vo. with an Aquatinti View by Medland. Price 8s. Boards.

In the Prefs, and fpeedily will be po:blifsed,

AN ACCOUNT of SOUTH WALES. BY BENJAMIN HEATH MALKIN, Efq. M. A. In One Volume 4to, with Plates by La Porte, after original Drawings by hinifelf. 


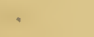

.

、 




DA730.B5 v.2 Botanical Garden Library gen

Bingley, William/North Wales; including

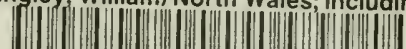

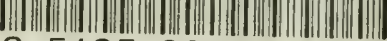

35185000734770

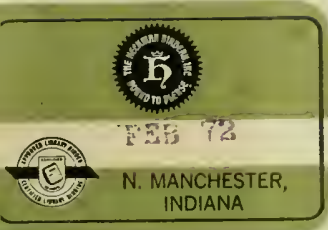


